MARKO

FERJAN

UREDNIK

\title{
IZZIVI \\ KADROVSKEGA \\ MANAGEMENTA \\ V XXI. STOLETJU
}

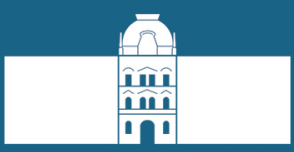



Univerza v Mariboru

Fakulteta za organizacijske vede

Izzivi kadrovskega managementa v XXI. stoletju

Urednik

Marko Ferjan

Februar 2021 
Naslov Izzivi kadrovskega managementa v XXI. stoletju

Title Challenges of Human Resources Management in XXI. Century

Urednik Marko Ferjan

Editor (Univerza v Mariboru, Fakulteta za organizacijske vede)

Avtorji Marko Ferjan, Iztok Podbregar, Antonia Novak, Polona Šprajc,

Authors Eva Jereb, Vesna Novak in Marko Urh.

Recenzija Mitja Gorenak

Review (Univerza v Mariboru, Fakulteta za turizem)

Branko Lobnikar

(Univerza v Mariboru, Fakulteta za varnostne vede)

Brigita Skela Savič

(Fakulteta za zdravstvo Angele Boškin)

Jezikovni pregled

Language editing

Milena Ilić

Tehnični urednik Jan Perša

Technical editor (Univerza v Mariboru, Univerzitetna založba)

Oblikovanje ovitka Jan Perša

Cover designer (Univerza v Mariboru, Univerzitetna založba)

Grafične priloge

Graphic material

Avtorji

Založnik Univerza v Mariboru

Published by Univerzitetna založba

Slomškov trg 15, 2000 Maribor, Slovenija

https://press.um.si, zalozba@um.si

Izdajatelj Univerza v Mariboru

Co-published by Fakulteta za organizacijske vede

Kidričeva cesta 55 A, 4000 Kranj, Slovenija

https://www.fov.um.si, dekanat.fov@um.si

Edition Prva izdaja

Vrsta publikacije

Publication type

E-knjiga

Dostopno na Available at

http://press.um.si/index.php/ump/catalog/book/535

Izdano

Published at

Maribor, februar 2021 
To delo je objavljeno pod licenco Creative Commons Priznanje avtorstva 4.0 Mednarodna.

/ This work is licensed under the Creative Commons Attribution 4.0 International License.

Uporabnikom je dovoljeno tako nekomercialno kot tudi komercialno reproduciranje, distribuiranje, dajanje $\mathrm{v}$ najem, javna priobčitev in predelava avtorskega dela, pod pogojem, da navedejo avtorja izvirnega dela.

Vsa gradiva tretjih oseb v tej knjigi so objavljena pod licenco Creative Commons, razen če to ni navedeno drugače. Če želite ponovno uporabiti gradivo tretjih oseb, ki ni zajeto v licenci Creative Commons, boste morali pridobiti dovoljenje neposredno od imetnika avtorskih pravic.

\section{https://creativecommons.org/licenses/by/4.0/}

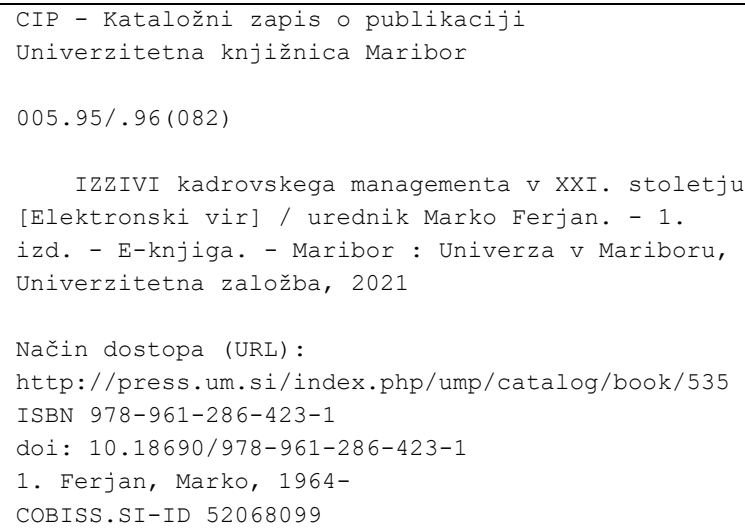

ISBN 978-961-286-423-1 (pdf)

\section{Cena
Price}

Odgovorna oseba založnika Forpublisher

Citiranje Attribution 978-961-286-424-8 (Trda vezava)

DOI https://doi.org/10.18690/978-961-286-423-1

prof. dr. Zdravko Kačič, rektor Univerze v Mariboru

Knjigo je sofinancirala Javna agencija za raziskovalno dejavnost Republike Slovenije.

Ferjan, M., (2021). Izzivi kadrovskega managementa v XXI.

stoletju. Maribor: Univerzitetna založba. doi:

https://doi.org/10.18690/978-961-286-423-1 



\section{Kazalo}

\section{Predgovor}

Foreword

Marko Ferjan

Merjenje zadovoljstva pri delu v digitalni dobi: uporabna vrednost ali akademska folklora?

Measuring Job Satisfaction in the Digital Age: Useful V alue or Academic Folklore?

Marko Ferjan

Procesno usposabljanje inovativnih kadrov, razvoj maksimalnega individualnega potenciala

Process Training of Innovative Staff, Development of Maximum Individual Potential

Iztok Podbregar, Antonia Novak in Polona Šprajc

Vodenje milenijcev in medgeneracijsko usklajevanje v organizacijah

Leading Millennials and Intergenerational Coordination in Organizations

Eva Jereb

Razširjenost prekarnega dela v digitalni dobi

Prevalence of Precarious Work in the Digital Age

Vesna Novak

Spremembe in tranzicije $\mathbf{v}$ času krize ter vloga vodstva pri tem

Change and Transition in Time of Crisis and the Role of Leadership

Eva Jereb in Marko Urh

Recenzije

Mitja Gorenak, Branko Lobnikar in Brigita Skela Savič 



\title{
Predgovor
}

\author{
MARKO FERJAN
}

Gonilna sila razvoja vsake znanstvene discipline so bili izzivi. Nič drugače ni bilo s kadrovskim managementom.

Kadrovski management, kot ga poznamo danes, se je začel razvijati ob koncu 19. stoletja kot posledica industrijske revolucije. O znanstvenih pristopih pa lahko govorimo od začetka 20. stoletja. Vsaj za obdobje zadnjih stotih let lahko rečemo, da so se mnoga podjetja $\mathrm{v}$ državah $\mathrm{z}$ uveljavljenim kapitalizmom trudila, da bi bili delavci zadovoljni, motivirani, da bi bili notranji odnosi v organizacijah prijazni. V nekaterih državah s socialističnim družbenim redom so si to razlagali kot uvajanje socializma in tako so učili tudi otroke in dijake $\mathrm{v}$ šolah. Vendar temu ni bilo tako, saj je $\mathrm{v}$ zahodni Evropi in ZDA v tistem času prevladovala doktrina neoliberalizma. Ključni izziv tistega časa je bil, kako povečati produktivnost tovarniških delavcev. $\mathrm{Za}$ večjo produktivnost je bil management pripravljen storiti vse: skrbeti za zadovoljstvo zaposlenih, izboljšati plače, izboljšati pogoje dela idr. To je seveda imelo pozitiven vpliv na splošno civilizacijsko raven družbe, vendar ne smemo pozabiti, da je bila v ozadju sla po dobičku. 
Po prvi naftni krizi konec šestdesetih in v začetku sedemdesetih let prejšnjega stoletja so se stvari spremenile. Na trgih v ZDA in Evropi so se pojavili produkti iz Japonske. Za njihov uspeh na trgu je bilo ključno dvoje: visoka kakovost produktov in zmožnost ponudnikov, da so stalno izboljševali izdelke. Za kadrovski management so postala aktualna povsem druga vprašanja; najprej vprašanja zagotavljanja kakovosti, nato pa vprašanja stalnega inoviranja. Če pogledamo evolucijo nekaterih izdelkov, ki jih vsakodnevno uporabljamo (npr. telefonski aparat ali televizor), ugotovimo, da so se $\mathrm{v}$ zadnjih desetletjih povsem spremenili. Po eni strani pokvarjenih aparatov danes praktično ne popravljamo več oziroma vsaj ne tako pogosto kot pred desetletji, po drugi strani se je čas od odkritij do uporabe novosti zelo skrajšal, podobno življenjski cikli izdelkov in storitev. Da bi organizacije vse to zmogle, so se mnoge odločale za koncept učeče se organizacije. Ta koncept ne pomeni zgolj učenja oziroma izobraževanja, pač pa precej več: iskanje talentov oziroma vrhunskih posameznikov, teamsko delo, ustvarjanje skupne vizije in skupnih mentalnih modelov, sistemsko razmišljanje in sistematično reševanje problemov, merjenje napredka idr. Vse to je od kadrovskega managementa terjalo drugačne pristope, kot je reševanje izzivov, povezanih s produktivnostjo.

Konec dvajsetega stoletja je prinesel nove izzive. Zahod je zmagal v hladni vojni, marketinški koncept segmentacije trgov je s tem lahko postal zgodovina in lahko se je začela moderna globalizacija. Z moderno globalizacijo je spet postalo aktualno vprašanje razlik v kulturah in bolj ali manj prikrita težnja po unifikaciji svetovne kulture. Vendar se s konceptom globalizacije in unifikacije sveta vsi pač niso strinjali in posledica tega so nove oblike terorizma in s tem povezana vprašanja varnosti. Vprašanja varnosti tako v 21. stoletju postanejo nov izziv, s katerim se mora resno soočiti tudi kadrovski management $\mathrm{v}$ organizacijah.

Začetek 21. stoletja je prinesel nova spoznanja in nove izzive. Razplet vojne v Siriji kaže, da svet ni več unipolaren oziroma da je unipolarnost trajala zgolj nekaj desetletij. Čeprav je bil to lokalen konflikt, so bili glavni akterji globalni, zato razplet tako simbolno kot dejansko vpliva na velik del sveta. Trgovinske vojne in protekcionizem so začeli nakazovati drugačne oblike globalnega sodelovanja med državami. Zgodil se je BREXIT. Vsaj prvi odzivi držav ob izbruhu virusnih bolezni so šli v smer zapiranja meja, ne pa v krepitev medsebojne solidarnosti. Vse kaže, da bo v bodoče vsaka država morala sama reševati svoje probleme. 
Generacije, na katerih je bil na nek način preizkušen klasični koncept kadrovskega managementa, so danes generacije upokojencev. Nove generacije svojo zaposlitev in življenje nasploh doživljajo povsem drugače kot njihovi starši, dedki in babice. Če je še pred desetletji prekarno delo veljalo za atipično obliko delovnega razmerja, danes temu ni več tako. Tudi delodajalci sklepajo drugačne oblike delovnih razmerij kot nekoč.

V nekaterih delih sveta upokojenci danes predstavljajo največji delež populacije. To s seboj prinaša povsem specifične probleme. Tipičen primer je Lombardija ob izbruhe epidemije. Za starejše generacije so danes ključna vprašanja zdravstva, socialnega varstva in oskrbe.

Z vsemi temi izzivi se mora soočiti tudi kadrovski management na ravni podjetij in drugih organizacij.

Marko Ferjan obravnava fenomene: zadovoljstvo pri delu, organizacijska klima in zavzetost. Koncept zadovoljstva pri delu izhaja iz paradigme organizacijskega vedenja. Konec 20. stoletja se je že zdelo, da v teoriji in praksi kadrovskega managementa koncept zadovoljstva ni več aktualen. Vendar v zadnjem obdobju merjenje zadovoljstva $\mathrm{v}$ povezavi $\mathrm{z}$ merjenjem zavzetosti spet postaja aktualno. Marsikatera današnja anketa zadovoljstva pa ne upošteva spoznanj znanosti, ni pa zanemarljivo, da je pri uporabi anket o zadovoljstvu včasih prihajalo tudi do zlorab. Zato se je avtor odločil za ponovno obravnavo te teme.

Iztok Podbregar, Antonia Novak in Polona Šprajc obravnavajo prepoznavanje, spodbujanje in vključevanje raznolikosti talentov ter zagotavljanje okolja, v katerem jih zaposleni lahko najbolje razvijajo. Ugotavljajo, da se je v vseh dejavnostih treba zgledovati po športnih organizacijah. V športu je uspeh v celoti neposredno odvisen od kakovosti posameznih talentov in tako je tudi v podjetjih.

Eva Jereb v prispevku najprej poda nekaj osnovnih značilnosti trenutno najbolj zastopanih generacij na delovnih mestih $\mathrm{v}$ organizacijah. To so tako imenovani babyboomerji, generacija X in milenijci. Nadalje so predstavljene osnove vodenja trenutno najobsežnejše generacije delovne sile, to je milenijcev. Podani so predlogi, kako ravnati z novo, mlado delovno silo in kako usklajevati predstavnike različnih generacij, da bodo le-ti zavzeti za delo in jih bodo organizacije sposobne zadržati. 
Vesna Novak obravnava razširjenost prekarnega dela. Spremenjeni pogoji dela, skladno z zahtevami poslovanja, narekujejo drugačne pristope in oblike zaposlovanja, kar vodi do naraščanja nestandardnih oblik dela. V Sloveniji smo v drugi dekadi tega stoletja začeli bolj množično uporabljati izraz prekarnost, večinoma $v$ neposredni povezavi z nestandardnimi oblikami zaposlitve. V prispevku najprej opredeli pojem prekarnosti. Nato se osredotoči na razmere na trgu dela. Posebno pozornost nameni posledicam prekarnosti.

Eva Jereb in Marko Urh se ukvarjata s spremembami in tranzicijo v času krize ter $z$ vlogo vodstva organizacij pri tem. Prispevek obravnava spremembe in tranzicije, skozi katere prehajajo zaposleni v času krize, in vlogo vodstva pri tem. Najprej so predstavljeni pojmi: kriza, spremembe in tranzicija. Nato so opredeljeni različni modeli tranzicije, kot so: krivulja sprememb Kübler-Ross, tranzicijski model po Bridgesu in nevrologistične stopnje sprememb po Diltsu. Skozi celoten prispevek so podani elementi, ki jih je smiselno upoštevati pri vodenju zaposlenih v času krize, sprememb in tranzicije. 


\title{
MERJENJE ZADOVOLJSTVA PRI DELU V DIGITALNI DOBI: UPORABNA VREDNOST ALI AKADEMSKA \\ FOLKLORA?
}

\author{
MARKO FERJAN \\ Univerza v Mariboru, Fakulteta za organizacijske vede, Kranj, Slovenija. \\ E-pošta: marko.ferjan@um.si
}

Povzetek Prispevek obravnava evolucijo konceptov zadovoljstva pri delu, organizacijske klime in kulture. Predstavljamo izvor in evolucijo navedenih konceptov. Gre za koncepte, ki so se pojavili po letu 1930 in so povezani z nastankom paradigme organizacijskega vedenja. Koncepti so skozi zgodovino doživeli svojo evolucijo. Nastanek teh konceptov je povezan $\mathrm{z}$ željo po večji produktivnosti delavcev v tovarnah. Koncepti izhajajo iz ekonomske doktrine liberalizma oziroma neoliberalizma in niso povezani $z$ uvajanjem komunističnih odnosov $\mathrm{v}$ tovarne. $\mathrm{V}$ različnih obdobjih so bili fenomeni pojmovani zelo različno. Zadovoljstvo pri delu je opredeljeno kot občutek, pridobljen s primerjavo med tistim, kar želimo, in tistim, kar nekdo pri delu dejansko ima. Zadovoljstvo ima lahko pozitiven ali negativen predznak. Organizacijska klima so stimulusi. Za današnje pojmovanje kulture je ključen Geert Hofstede. $\mathrm{K}$ pojmovanju organizacijske kulture in kulture nasploh je zelo veliko doprinesla raziskava GLOBE. Koncepti zadovoljstva pri delu, organizacijske klime in kulture so preživeli paradigmo organizacijskega vedenja in so aktualni še danes. Ker je narava dela danes drugačna, jih je treba obravnavati drugače kot v 20. stoletju.

Ključne besede: kadrovski management, zadovoljstvo pri delu, zavzetost, organizacijska klima, efekt Hawthorne. 


\title{
MEASURING JOB SATISFACTION IN The Digital Age: Useful Value OR ACADEMIC FOLKLORE?
}

\author{
MARKO FERJAN \\ University of Maribor, Faculty of Organizational Sciences, Kranj, Slovenia. \\ E-mail:marko.ferjan@um.si
}

\begin{abstract}
The article discusses the evolution of the concepts of job satisfaction, organizational climate and culture. We present the origin and evolution of the concepts. These are concepts that appeared after 1930 and are associated with the paradigm of organizational behaviour. Concepts tried to answer the question: how to improve the productivity of workers in factories. The concepts derive from the economic doctrine of liberalism or neoliberalism and are not related to the introduction of communist relations in factories. Through the era, the phenomena were understood very differently. Now, job satisfaction is defined as the total relationship between an individual and the employer for which he is paid. Satisfaction is an emotion and can be positive or negative. Organizational

culture is defined as the underlying beliefs, assumptions, values and ways of interacting that contribute to the unique social and psychological environment of an organization. In this era, we understand an organizational climate as a positive stimulus for creativity. The concepts of job satisfaction, organizational climate and culture have survived the paradigm of organizational behaviour and are still relevant today. Because the nature of work is different today, they need to be treated differently than in the 20th century.
\end{abstract}

Keywords:

Human

resources

management,

job

satisfaction,

work

engagement,

oIrganiaztional

climate, effect

Hawthorne. 


\section{Opredelitev problema}

Tako kot mnoga klasična dela s področja kadrovskega managementa v zadnjem stoletju se tudi vsebina našega prispevka začenja $\mathrm{v}$ tovarni Western Electric v kraju Hawthorne blizu Chicaga. Šlo je za klasično vprašanje takratnega kadrovskega managementa: »Kako doseči, da bodo delavci bolj produktivni?« Med letoma 1924 in 1933 so zato s skupino 300 prostovoljcev izvajali serijo poskusov, s katerimi so želeli ugotoviti, kako fizikalni pogoji dela (osvetlitev) vplivajo na produktivnost. Pri raziskavi je sodelovala tudi skupina raziskovalcev iz Harvard Business School. Skupina raziskovalcev je opravila kar 21.000 intervjujev z delavci. Izkazalo se je, da je bila skupina 300 prostovoljcev, ki so jim spreminjali osvetlitev, bolj produktivna od ostalih 21.000 delavcev v tovarni, ne glede na pogoje osvetlitve delovnih mest.

V zadnjem stoletju so bila bolj ali manj aktualna tudi številna druga vprašanja kadrovskega managementa: vprašanja zagotavljanja kakovosti, inoviranja, medkulturnega sodelovanja in varnosti. Vprašanje produktivnosti je vedno bolj ali manj aktualno; manj v krizah, bolj pa v času velikega povpraševanja. Eden od odgovorov managementa na to, kako povečati produktivnost delavcev, je zagotavljanje zadovoljstva. Tudi če ima zagotavljanje zadovoljstva povsem ekonomsko ozadje, ga je treba razumeti tudi kot pridobitev civilizacije.

Avtor tega prispevka sem v svoji poklicni karieri imel možnost prebrati več sedaj aktualnih poročil o merjenju zadovoljstva pri delu. Ugotovil sem, da so z razumevanjem konceptov zagotavljanja zadovoljstva pri delu in s samim merjenjem lahko tudi težave. To, da mnogi ugotavljajo, da tudi še tako zelo zadovoljni delavci lahko niso produktivni, je še najmanjša težava. Mnogi namreč težko slišijo, da je poleg zadovoljstva pomembna tudi zavzetost zaposlenih.

Koncept zadovoljstva pri delu je reverzibilen proces, saj pogosto služi tudi ocenjevanju uspešnosti managementa. Pri tem pa zaradi neznanja lahko pride do neverjetnih težav. V istem poročilu o raziskavi zadovoljstva v neki organizaciji smo lahko prebrali, da so odnosi dobri, le kako stran naprej pa, da so slabi. Opazili smo tudi zelo abstraktna vprašanja, kot npr. kakšno je zadovoljstvo z načinom vodenja, pri čemer nikomur ni znano, kaj pojem »način vodenja« sploh pomeni. Vsebina vprašalnikov zelo pogosto ni sistematično strukturirana, da bi se vedelo, kaj je predmet vprašanja. Uporabljene so nenavadne lestvice odgovorov. Včasih je celo 
videti, da sestavljavci ankete sploh ne razumejo osnovnih pojmov. Pri merjenju zadovoljstva in zavzetosti je treba biti sistematičen in natančen.

Naš prispevek je namenjen tako teoretikom kot praktikom. Namen je predstaviti osnovne pojme o zadovoljstvu pri delu in v povezavi s tem tudi o zavzetosti na način, da bi jih tako praktiki kot akademiki znali uporabljati v praksi.

\section{Uvod}

Naj nadaljujemo s poskusi $\mathrm{v}$ tovarni Western Electric pred nekaj manj kot sto leti. Nekateri avtorji se danes sklicujejo na kasnejše analize shranjene dokumentacije, ki so po njihovem mnenju pokazale, da opisi osvetljevalnih eksperimentov, ki so običajno predstavljeni $\mathrm{v}$ učbenikih in drugih virih, govorijo o nepopolni in včasih popolnoma napačni zgodbi in da je ta eksperiment postal del akademske folklore. Po njihovem mnenju eksperiment dokazuje zgolj to, da osvetlitev ni vplivala na delovno uspešnost (kar je $z$ današnjega vidika sicer nelogično).

Za takratno interpretacijo rezultatov je bil ključen psiholog George Elton Mayo (18801949). Kakorkoli je že v resnici bilo, tako poskusi kot Elton Mayo so se zapisali v zgodovino. Rodila se je paradigma organizacijskega vedenja, ki je bila prevladujoča paradigma kadrovskega managementa skoraj do konca 20. stoletja. Ključne ugotovitve, kakor jih je interpretiral Elton Mayo, so bile:

- posamezniki imajo lahko vrhunski potencial, toda njihova produktivnost je močno odvisna tudi od socialnih dejavnikov,

- pravila za skupino (kot npr. delovni čas) vplivajo na produktivnost,

- neformalna organizacija vpliva na produktivnost,

- vsaka organizacija ima tudi neformalno komponento,

- stopnja nadzora vpliva na produktivnost.

Mayo (1933) je trdil, da je večja produktivnost skupine prostovoljcev posledica vpliva skupine na posameznike in tudi pogojev dela, odnosov v skupini ipd. Začelo se je razmišljati o odnosih znotraj organizacije, pogojih dela, oblikovanju skupin, neformalnih organizacijah, plačah, delovnem času, zadovoljstvu pri delu ipd. 
Vendar že takrat niso bili vsi takega mnenja. Uhrbrock (1934) je menil, da delavce »držijo pokonci« trije temeljni strahovi:

- strah pred izgubo službe,

- strah pred nezmožnostjo za delo zaradi poškodbe ali bolezni,

- $\quad$ strah pred tem, da bi bili v starosti brez sredstev za preživljanje.

Menil je tudi, da so razlogi za nerazumevanje v nižji inteligenci posameznih skupin delavcev.

Poskusi v tovarni v kraju Hawthorn so bili kasneje predmet številnih analiz. Leta 1974 je Parsons raziskoval, kaj naj bi se v resnici dogajalo v Hawthornu. Ugotovil je, da je bolj verjetno, da je na večjo produktivnost vplivala kombinacija povratnih informacij (npr. tehnologov) in finančne nagrade delavcem. Prepoznal je tudi, da v eksperimentalnih raziskavah obstaja neželen učinek samih eksperimentalnih operacij. Poimenoval ga je Hawthornov efekt. Hawthornov efekt je fenomen, ko se ravnanje udeležencev $\mathrm{v}$ eksperimentu spremeni zaradi njihovega zavedanja, da sodelujejo v eksperimentu.

Podoben koncept poskusa, kot je bil opravljen v tovarni Western Electric, sta leta 1978 opravila Franke in Kaul. V skupini sta zamenjala samo dva delavca in produktivnost se je spremenila.

Mannevuo (2018) ugotavlja, da so bili prostori za eksperimente v tovarni Western Electric posebej zasnovani prav za eksperimente, delavce je spremljala skupina inženirjev in industrijskih raziskovalcev, dobivali so dnevno plačo, imeli so krajši delovni čas.

Izawa, French in Hedge (2011) so na podlagi vseh ohranjenih dokumentov opravili zelo natančno statistično analizo eksperimentov. Statistične analize podatkov o produktivnosti iz treh osvetljevalnih eksperimentov, izvedenih na Hawthorne Works, kažejo neskladne zveze med razsvetljavo in produktivnostjo.

$\mathrm{Na}$ podlagi ohranjenih dokumentov in sodobnih analiz danes lahko utemeljeno dvomimo v pravilnost zaključkov takratnih poskusov. 
Kot rečeno, je v tistem času prevladala interpretacija Eltona Maya. Elton Mayo pa ni poznan zgolj kot tisti, ki je interpretiral rezultate poskusov v tovarni Western Electric v kraju Hawthorne, pač pa je opravljal tudi druge raziskave. Med drugim je preučeval vpliv plače na produktivnost zaposlenih. Njegovo delo je imelo izjemno velik vpliv na nadaljnja raziskovanja in tudi na prakse kadrovske funkcije $\mathrm{v}$ naslednjih desetletjih. Pod vplivom poskusov v kraju Hawthorne in del Eltona Maya so bile v naslednjih desetletjih objavljene številne raziskave in teorije o motivaciji in motiviranju, o neformalnih organizacijah, o delovnem času ..., kot npr.:

- Poročilo o prvi raziskavi zadovoljstva pri delu je objavil Richard Stephen Uhrbrock leta 1934 (objavljen je bil leta 1934, reviji ga je v recenzijski postopek poslal 13. 9. 1933).

- Med letoma 1959 in 1964 je Frederick Irving Herzberg (1923-2000) objavil vrsto člankov o motivaciji, leta 1968 pa še zelo poznano dvofaktorsko teorijo motivacije.

- Renato Tagiuri (1919-2011) je bil leta 1968 prvi, ki je definiral pojem »organizacijska klima«.

Prvo lestvico za merjenje indeksa zadovoljstva zaposlenih sta leta 1951 objavila Arthur Brayfield in Harold Rothe.

Eden najbolj poznanih avtorjev obravnave zadovoljstva pri delu je Frederick Irving Herzberg (1923-2000). Med letoma 1959 in 1964 je objavil vrsto člankov o motivaciji, leta 1968 pa še zelo poznano dvofaktorsko teorijo motivacije. Vprašanje, ki si ga je zastavil v uvodu članka iz leta 1968, je bilo: »Kako naj dosě̌ẹm, da bodo zaposleni delali to, kar jaz hočem?

Poročilo o tej raziskavi je bil eden najbolj branih in citiranih člankov področja managementa nasploh. $Z$ vidika današnjega časa ima nekatere pomanjkljivosti. Raziskava je bila opravljena na vzorcu zgolj nekaj več kot 200 oseb, šlo pa je za administrativno-tehnični kader. Vzorec je bil torej majhen in ni zajel vseh kategorij zaposlenih. 
Ne glede na to, pa je tudi v naslednjih desetletjih obveljala ključna ugotovitev tega članka. Ta pa je bila, da se dejavniki zadovoljstva ter dejavniki nezadovoljstva med seboj razlikujejo, torej ne gre za eno in iste vrste kategorijo, temveč za dve različni kategoriji. niso ene in iste vrste kategorija.

Renato Tagiuri (1919-2011) je bil leta 1968 prvi, ki je definiral pojem »organizacijska klima«. Tagiuri je bil že leta 1968 med prvimi, ki je definiral pojem organizacijska klima (organization climate). isto Postavil je definicijo: »Organizacijska klima je kakovost notranjega okolja organizacije, ki (a) jo člani organizacij zaznavajo, (b) vpliva na obnašanje (ravnanje) članov organizacije, (c) vpliva na sistem vrednot članov organizacije.

Kot je poročal Locke, je bilo do leta 1976 opravljenih več kot tri tisoč študij o zadovoljstvu pri delu. Interpretacije razlogov za tolikšen interes preučevanja zadovoljstva so različne. Vedeti moramo, da vse te raziskave niso bile opravljene $\mathrm{v}$ državah s komunistično družbeno ureditvijo, pač pa v državah, kot so ZDA in države zahodne Evrope. To je bil seveda kapitalistični svet, kjer je takrat prevladovala doktrina neoliberalizma. Ključni razlog tako velikemu interesu za preučevanje zadovoljstva pri delu je lahko samo eden - kako povečati produktivnost.

V drugi polovici 20. stoletja, zlasti po letu 1970, so se povsem spremenila vprašanja, na katera je moral odgovoriti kadrovski management $v$ podjetjih: prišlo je do robotizacije proizvodnje, masovni obseg njihove uporabe $\mathrm{v}$ industriji pa odpira povsem nova vprašanja industrijskih odnosov. Vzporedno z uvajanjem robotizacije $\mathrm{v}$ industriji so trge zahodne Evrope in ZDA v sedemdesetih letih prejšnjega stoletja preplavili avtomobili in izdelki zabavne elektronike iz Japonske. Ti izdelki so bili bolj kakovostni kot evropski in ameriški. Fokus kadrovske funkcije v podjetjih se je zato moral spremeniti. Če je bilo prej ključno vprašanje produktivnosti, sta v novih okoliščinah to postali vprašanji kakovosti in stalnega izboljševanja produktov.

To obdobje na nek način predstavlja začetek konca industrijske družbe. Vprašanja, kako povečati produktivnost industrijskih delavcev, kar naenkrat niso bila več $\mathrm{v}$ prvem prioritetnem planu. Pojavile so se nove paradigme kadrovskega managementa. Če za obdobje med letoma 1930 in 1970 lahko rečemo, da je bilo to obdobje razcveta preučevanja organizacijskega vedenja, v katerega sodi tudi 
preučevanje zadovoljstva pri delu, pa se po letu 1970 ni pojavilo prav veliko novih teorij. Kljub temu pa se mnoge organizacije merjenja zadovoljstva pri delu še vedno poslužujejo. Ob branju poslovnih časopisov dobimo celo občutek, da vprašanja zadovoljstva spet prihajajo v ospredje. Razlog temu do neke mere ostaja skrb za produktivnost. $\mathrm{V}$ obdobju gospodarske rasti je ponudba na trgu dela majhna, obstaja deficit nekaterih poklicev in za delojemalce je vsekakor pomembno, da delodajalec zadovolji njihova pričakovanja. Westfall (2019) pravi, da podjetja, osredotočena na prihodnost, pretehtajo, kaj si zaposleni resnično želijo - in to ni samo plača. Dobri vodje vedo, da je večje zadovoljstvo $z$ delovnim mestom najlažji način za boj proti fluktuaciji, absentizmu in frustraciji zaposlenih.

Kot pravi Kohll (2018), so se skozi leta želje in zahteve zaposlenih spreminjale in razvijale, zato je podjetjem zagotavljanje zadovoljstva lahko izziv. Delodajalci so s strani različnih svetovalcev dobesedno bombardirani s široko paleto trendovskih nasvetov, kako naj zagotovijo zadovoljstvo generacijam delavcev. Ko pa gre za privabljanje in ohranjanje vrhunskih talentov, morajo delodajalci razumeti, kaj si zaposleni od podjetja sploh želijo.

Kelly (2019) pravi, da se v ZDA v času objave njegovega članka ponašajo z najvišjo stopnjo zaposlenosti $\mathrm{v}$ desetletjih. Borza cveti, vendar se zdi, da je nekaj narobe. Mnogi ljudje se počutijo brezposelni, obtičijo na svojih slepih kariernih poteh in ne zaslužijo niti blizu tistega, kar menijo, da so vredni. Ljudje ne delajo del po svoji izbiri, ampak zaradi pomanjkanja ustreznih priložnosti. To poraja vprašanja, koliko ljudi je dejansko na »dobrih« delovnih mestih.

Kruse (2012) npr. pravi, da podjetje lahko ponudi zaposlenim vse možne bonitete. To sicer lahko pomeni, da bodo zaposleni bolj zadovoljni. Ni pa nujno, da bodo zadovoljni zaposleni tudi zavzeti. V zadnjih desetletjih se zadovoljstvo pri delu preučuje (oziroma bi se vsaj moralo preučevati) vzporedno z drugim fenomenom zlasti s fenomenom zavzetosti.

V Sloveniji je eno takih raziskav opravil Branko Lobnikar. Lobnikar (2016) je januarja 2015 opravil raziskavo zavzetosti na Univerzi v Mariboru, ki ima približno 1.800 zaposlenih. Vzorec je zajemal 200 zaposlenih (od tega: $60 \%$ visokošolskih učiteljev in sodelavcev in $40 \%$ strokovnih sodelavcev). Vzorec je bil reprezentativen. 
Uporabil je Gallup Q12 vprašalnik. Ugotovil je, da kar 30,5 \% anketiranih sodi v skupino aktivno nezavzetih.

Aktivno nezavzeti niso samo nezadovoljni na svojem delovnem mestu; svoje nezadovoljstvo tudi aktivno izkazujejo. Podcenjujejo delo, ki ga opravijo njihovi zavzeti sodelavci, in škodljivo vplivajo tudi na zavzetost in zadovoljstvo strank.

Take ugotovitve niso nič novega, nič presenetljivega in niso značilne samo za Slovenijo. Take rezultate kaže več akademskih raziskav in raziskav svetovalnih podjetij, opravljenih $\mathrm{v}$ zadnjih letih. Eno zadnjih so opravili Hayes in soavtorji (2019). Anketirali so 18.000 oseb v različnih državah. Resnici na ljubo je treba priznati, da raziskovalci niso uporabili katerega od uveljavljenih vprašalnikov (npr. UWES ali Gallup Q12) niti v poročilu o raziskavi ni navedeno, katere so bile partnerske ustanove po posameznih državah. Toda na njihove ugotovitve se sklicuje tudi Forbes (npr.: Bendaly 2019), zato menimo, da je dovolj verodostojna. Raziskava je pokazala, da je v povprečju samo 15,9\% vseh zaposlenih v službi polno zavzetih. Obstajajo pa velike razlike tako med državami kot med poklici.

\section{Zadovoljstvo, zavzetost in organizacijska klima}

\section{Zadovoljstvo pri delu (angl.: job satisfaction)}

V literaturi obstaja ogromno definicij pojma »zadovoljstvo pri delu«. Eno prvih je postavil Bullock (1952), ki pravi, da je zadovoljstvo pri delu rezultat ravnovesja in seštevanja številnih posebnih »všečkov« in »nevšečkov«v povezavi s službo.

Locke (1969) pravi, da je zadovoljstvo pri delu opredeljeno kot občutek, pridobljen s presojo dela. Po njegovem mnenju v tem procesu obstajajo trije dejavniki presoje:

- zaznavanje vidika dela,

- vrednostni sistem in

- ocena razmerja med percepcijo in vrednostnim sistemom.

Ljudje so si v mislih postavili cilje in vrednote. Če jim delo pomaga pri doseganju teh ciljev, so zadovoljni. 
Smith in Stone (1992) opredeljujeta zadovoljstvo pri delu kot čustveno stanje, upoštevajoč, kaj zaposleni pričakujejo in kaj so dejansko dobili.

Robbins (2005) definira zadovoljstvo pri delu kot set emocij, ki jih nekdo čuti v zvezi $\mathrm{z}$ delom.

Smith, Kendall in Hulin (1969) definirajo zadovoljstvo kot občutke in kot odzive na situacije $\mathrm{v}$ zvezi z delom.

Hulin in Judge (2003) sta zadovoljstvo pri delu opredelila kot večdimenzionalni psihološki odziv na neko delovno mesto. Ti odzivi imajo kognitivne, čustvene in vedenjske sestavine.

Pregled definicij pojma »zadovoljstvo pri delu« zadnja desetletja pokaže, da imajo vse definicije nekatere skupne značilnosti:

- vsebina oziroma objekt, na katerega se zadovoljstvo pri delu nanaša, je multidimenzionalen, lahko je objekt iz fizičnega okolja (npr. značilnosti samega delovnega mesta oziroma delovnega okolja), lahko so socialne interakcije (vezane na konkretno delo oziroma konkretno delovno mesto), lahko je kombinacija naštetega, $v$ vsakem primeru pa se navezuje na delovno mesto oziroma konkretno delo, ki ga nekdo opravlja,

- večina definicij zadovoljstvo pri delu opredeljuje kot čustvo,

- čustvo je lahko bolj ali manj izraženo, lahko je v obliki zadovoljstva, lahko tudi $\mathrm{v}$ obliki nezadovoljstva,

- nekateri avtorji kot atribut zadovoljstva pri delu poleg čustev naštevajo tudi kognicijo in odzive na zaznave.

Za razumevanje fenomena zadovoljstva pri delu je treba najprej razumeti fenomen percepcije, kognicije in emocij. Fenomeni percepcije, kognicije in emocij nastanejo na podlagi človekove zaznave.

Do percepcije pride, ko človek zaznava dražljaje iz fizikalnega okolja. Proces percepcije z medicinskega gledišča poteka tako, da senzorični organi preoblikujejo prejeto vhodno energijo zaznanega senzoričnega dražljaja iz fizičnega sveta $\mathrm{v}$ aktivnosti živčevja, signali se iz čutil preko živčevja prenašajo v možgane. V 
možganih se mentalno obdelujejo in na podlagi zaznanih dražljajev in mentalne obdelave pride do "ponovne vzpostavitve« slike iz okolja. Ponovna vzpostavitev slike $\mathrm{v}$ možganih na podlagi zaznanega objekta iz fizičnega okolja se imenuje percepcija (Goldstein, 2009). Percepcija torej proces, v katerem socialno okolje ne sodeluje.

$\mathrm{V}$ proces kognicije pa je vključeno tudi socialno okolje. Kognicija je proces spoznavanja na osnovi zaznav dražljajev iz fizičnega sveta in interakcij posameznika s fizičnim in s socialnim okoljem.

Kognicija z vključitvijo socialnega okolja v proces spoznavanja pomeni več, kot je proces percepcije. Poleg zaznav so za kognicijo ključnega pomena tudi interakcije z različnimi posamezniki znotraj socialnega okolja in interakcije posameznika s socialnim okoljem kot celoto. Kognicija se po vsebini torej lahko nanaša na nekaj, kar posameznik s svojimi čutili ne zazna kot objekt zaznave iz fizičnega okolja. Zadovoljstvo oziroma nezadovoljstvo je torej lahko tudi posledica kognicije, ne pa zaznave iz fizičnega okolja. Do kognicije lahko pride, ne da bi človek nekaj zaznal iz fizičnega okolja. Zaznavo iz fizičnega okolja lahko nadomesti zaznava iz socialnega okolja; npr. nekdo nekomu nekaj pove ali napiše. To je za razumevanje zadovoljstva pri delu izjemno pomembno.

V procesu kognicije gre po Marcumu (2014) za zaporedje več procesov:

Biološki proces na ravni posameznika poteka z zaznavo v okviru sistema človekovih čutil, prenosa dražljajev preko živčevja v možgane in percepcija.

Kognitivni proces na individualni ravni posameznika, na katerega vplivajo: zaznava, vnaprejšnja človekova mišljenja ter časovni, prostorski ter situacijski dejavniki okolja.

"Podaljšek» kognitivnega procesa; poleg časovnih, prostorskih ter situacijskih dejavnikov (fizičnega in socialnega) okolja pride še do interakcij v socialnem okolju. Interakcije v socialnem okolju (npr.: med člani skupine) so zelo kompleksne. Pride do povratnih zank med člani socialnega okolja (skupine). Povratne zanke so lahko pozitivne ali negativne, kar pomeni, da zaradi njih lahko pride do »ojačitev« ali do »slabitev« kognicij. 
Marcum (2014) pravi, da na individualni ravni posameznika kognicija brez zaznave sploh ni možna. Našteva pa šest dejavnikov okolja, ki vplivajo na output procesa kognicije.

Situacijski dejavnik okolja: ista zaznava (isti input v proces kognicije) v različnih situacijah v okolju lahko povzroči popolnoma različne outpute.

Časovna komponenta pomeni, da ista zaznava v različnih časovnih obdobjih lahko povzroči popolnoma različne kognicije.

Efekt »razbremenitve« - za sklepanje zaključkov se včasih v množici zaznav pojavi točno tista, ki si jo človek želi. Na osnovi te zaznave lahko sklene popolnoma napačen zaključek.

Sprožilni mehanizem - vključitev okolja je potrebna, da se proces spoznavanja nečesa na ravni posameznika sploh začne. Brez vključitve okolja zaznava na ravni posameznika sicer obstaja, vendar ne pride do kognicije.

Kognicija je lahko posledica dosedanjega delovanja ali obnašanja.

Če se pojav dogaja v skupini, govorimo o kolektivni kogniciji. Da bi se pri ugotavljanju zadovoljstva izognili temu pojavu, je torej pomembno, da ne sprašujemo po mnenju o nečem (npr. Ali menite, da ste zadovoljni?), ampak da sprašujemo ljudi, ali so oni osebno zaznali neko stvar ali nek pojav.

»Podaljšek« kognitivnega procesa na ravni posameznika pomenijo interakcije med člani socialnega okolja. Psihologi ločijo: kognicijo na ravni posameznika in kognicijo na ravni skupin. Skupine imajo kognitivne sposobnosti, ki presegajo enostavne agregacije kognitivnih zmožnosti posameznikov.

Interakcije med posameznikom in socialnim okoljem vplivajo na kognitivni proces na individualni ravni. Lahko pa pride tudi do kolektivne kognicije. Poenostavljeno povedano: kolektivna kognicija pomeni "prepis« spoznanj in stališč med člani skupine oziroma v družbi kot celoti. Kot povzema De Risio (2014), je ključnega pomena za razumevanje fenomena kolektivne kognicije to, da pri članih socialnega okolja pogosto lahko opazimo enak način dojemanja zaznav. 
Fenomen kolektivne kognicije opisuje več teorij. Brower in Nurius (1993) opisujeta »kognitivno-ekološki model«. Bistvo te teorije je v trditvi, da je primarna motivacija vrst, tudi ljudi, praviloma v tem, da ostanejo in preživijo v istem okolju. Pri človeku imamo opravka s fizičnim okoljem in s socialnim okoljem. Da bi se vrste sploh lahko ohranile same po sebi, morajo za svoje potrebe uporabljati okolje, ne da bi okolje uničile. Skozi evolucijo so vrste razvile ravnanja in najboljše možne odzive na različne situacije v okolju.

Teorija najpogosteje opisuje zadovoljstvo kot čustvo. Biološki mehanizem nastanka človekovih čustev je dokaj dobro raziskala nevroznanost. Kot navaja Ingram (2015), ki se sklicuje na številne novejše znanstvene dokaze, so čustva posledica delovanja možganov, vendar niso povezana s človekovo inteligenco. Čustva nastanejo v predelu možganov, imenovanem »amygdala«. Ljudje, ki so v nesrečah doživeli poškodbe tega dela možganov, se na zaznave čustveno ne odzivajo. Ingram (2015) meni, da gre pri nastanku čustev za refleks in da se čustvenega odzivanja ni mogoče naučiti. Vendar pa je ta refleks, zlasti njegova intenzivnost, povezan z izkušnjo. Glede na človekove izkušnje je med ljudmi refleks lahko zelo različen.

Emocije oziroma čustva in razpoloženja so odzivi človeškega telesa na zaznave iz okolja. Nastanek čustev je povezan z zaznavo in s preteklimi izkušnjami. Predpogoj za pojav čustva in razpoloženja je izpostavljenost izkušnji ali situaciji, ki v nevrološkem sistemu predstavlja sprožilno zaznavo za čustvene odzive.

Nekatere teorije opisujejo zadovoljstvo tudi kot odziv. Pennington (2000) ravnanja ljudi razvrsti v:

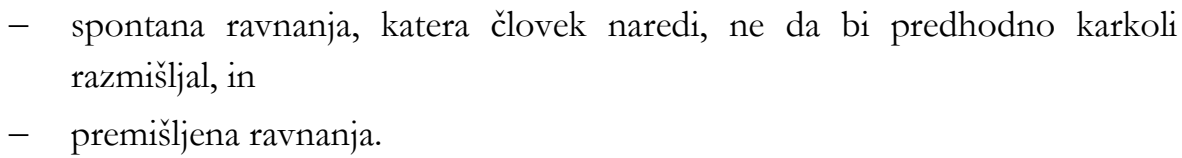

Teorij, kaj je pravzaprav tisto, kar povzroči človekovo ravnanje, je sicer več. V 20. stoletju je bila najbolj uveljavljena teorija S-R (stimulus-response) (Kitchener in O'Donohue, 1999). Behaviorizem je po teoriji S-R človekov odgovor (odziv) na dražljaje (stimuluse) iz okolja v obliki refleksov in ravnanj. Refleksi in ravnanja so posledica zaznanih dražljajev, vplivov človekovih genov, preteklih izkušenj, zdravstvenega stanja in drugih dejavnikov. 
Nekateri psihologi karikirajo, da čustev sploh ne »čutimo«, pač pa jih samo »mislimo«. Misli so zgolj en del čustev. So mentalni odziv na zaznane dražljaje. Odziv na zaznave, ki sprožijo pojav čustva, pa ni samo miseln. Odzove se tudi človekovo vegetativno živčevje. To povzroči še druge odzive in spremembe $\mathrm{v}$ človekovem telesu. Iz vsakdanjega življenja poznamo odziv obraznih mišic (npr. smeh). Kot navajajo Härtel in soavtorji (2015), je čustvene odzive človeškega telesa na zaznane dogodke možno relativno enostavno meriti:

- v endokrinologiji: čustveni odziv povzroči spremembe ravni: kortizola, testosterona in oxytocina,

- v kardiologiji: čustveni odziv povzroči spremembe srčnega utripa, krvnega tlaka in spremembe $\mathrm{v}$ zapisu EKG,

- v dermatologiji: čustveni odziv povzroči spremembe električne prevodnosti kože,

- čustva imajo lahko tudi dolgoročni vpliv na zdravje.

Vpliv čustev na zdravje je predmet raziskav že vsaj od leta 1970. Eno od zadnjih raziskav so opravili Ottaviani, Shapiro, Goldstein in Gofman (2012). Z meritvami so dokazali, da čustva vplivajo na krvni tlak. Ugotovili pa so tudi, da vpliv čustev na krvni tlak ni pri vseh ljudeh enak. Odvisen je od osebnostnih lastnosti posameznika.

Eden prvih prepoznanih simptomov vpliva delovnega mesta na človeka je bil sindrom izgorelosti. Izgorelost je mentalna in čustvena izčrpanost, ki je posledica poklicnega življenja. Izgorelost na delovnem mestu oziroma »burnout sindrom« je postal predmet znanstvenih preučevanj v sedemdesetih letih prejšnjega stoletja. Izraz »izgorelost« (»burnouk«) je bil najprej uporabljen med strokovnjaki za duševno zdravje. Prvi naj bi ga uporabil Herbert J. Freudenberger. Pomeni čustveno izčrpanost, depersonalizacijo in zmanjšan občutek osebnega dosežka (Freudenberger, 1974).

Ker so izgorelost prvi preučevali psihologi, se prve definicije nanašajo zgolj na čustva. Yavuz in Dogan (2014) pravita, da je izgorelost sindrom čustvene izčrpanosti in cinizma posameznika. Ključni vidik sindroma izgorelosti je torej povečanje čustev izčrpanosti. Drugi vidik je razvoj negativnih, ciničnih odnosov in občutkov. Vendar 
izgorelost ne pomeni zgolj čustvene izčrpanosti, pač pa pomeni tudi fizično izčrpanost.

Za merjenje hipotetičnih vidikov izgorelosti je bil leta 1981 zasnovan vprašalnik, imenovan »Maslach burnout inventory (MBI)« (Maslach, 1981). Koncept izgorelosti, kot je postavljen v vprašalniku MBI, ima tri dimenzije: izčrpanost, cinizem in zmanjšano učinkovitost. Uporaba vprašalnika se je razširila na vse tiste vrste poklicev in poklicnih skupin, za katere je značilno delo z drugimi ljudmi (npr.: zdravstvo, socialno varstvo, izobraževanje). Čeprav je MBI star že več kot 40 let in je doživel številne kritike, se še vedno uporablja. Poghosyana, Aikenb in Sloaneb (2009) so tako na podlagi MBI vprašalnika opravili raziskavo izgorevanja v bolnicah v ZDA, Kanadi, Nemčiji, Novi Zelandiji, na Japonskem, v Rusiji in Armeniji. Vzorec je obsegal 54.738 zaposlenih v zdravstveni negi iz 646 bolnic. Ugotovili so, da med državami sicer obstajajo razlike, vendar imajo rezultati po vseh državah podobno faktorsko strukturo.

MBI vprašalnik je doživel tudi številne kritike. Kritiki se sicer strinjajo, da so dimenzije izčrpanosti take, kot so navedene v MBI raziskavi, vendar pa ugotavljajo, da faktorska analiza rezultatov nekaterih raziskav pri poklicih izven zdravstvene nege ne sledi teoretičnemu modelu. Med elementi izgorelosti v različnih okoljih obstajajo razlike. To sta ugotovila tudi Yavuz in Dogan (2014) z raziskavo, opravljeno v Turčiji.

Zaradi kritik so bili razviti novi modeli za merjenje izgorelosti. Demerouti in soavtorji (2001) so razvili model, imenovan »Oldenburg Burnout Inventory (OBI)«. Ta model je dvofaktorski, saj vključuje samo dva faktorja: izčrpanost in nezavzetost. Kristensen in soavtorji (2007) pa so razvili »The Copenhagen Burnout Inventory (CBI)«. CBI je sestavljen iz treh lestvic, ki merijo osebno izgorelost, izgorelost, povezano z delom, in izgorelost, povezano z odjemalci.

$\check{Z}$ e desetletja je poznano, da je zadovoljstvo pri delu povezano s problemom nespečnosti.

Totterdell, Reynolds, Parkinson, and Briner (1994) poročajo, da je kakovost spanja bolj povezana z dobrim počutjem po spanju kot pred spanjem. 
Brissette and Cohen (2002) sta ugotovila, da so problemi s spanjem povezani z negativni efekti, pozitivnimi dogodki prejšnjega dne pri tem nimajo vpliva.

Gu, Yuanbo in soavtorji (2020) so izvedli enoletno raziskavo na vzorcu 298 vzgojiteljev. Rezultati so pokazali, da nenehna izpostavljenost stresu na delovnem mestu sčasoma negativno vpliva na počutje.

Problem je prepoznala tudi skupina profesorjev z Univerze v Bergnu na Norveškem. Čeprav obstaja več drugih lestvic za merjenje nespečnosti (npr.: Athens Insomnia Scale, Pittsburgh Sleep Quality Index, idr.), so razvili lestvico za merjenje nespečnosti (Bergen Insomnia Scale (BIS) (Pallesen et al., 2008).

\section{Organizacijska klima (angl. organizational climate)}

Organizacijska klima je eden od konceptov, ki se je pojavil znotraj paradigme organizacijskega vedenja. Prvi, ki je definiral pojem »organizacijska klima«, je bil Renato Tagiuri leta 1968. Po njegovem mnenju naj bi organizacijska klima pomenila subjektivno percepiranje organizacije kot sistema. Gre za percepiraje dogajanja, praks in procedur na ravni organizacije. Organizacijska klima se torej nanaša na organizacijo kot celoto, področje zadovoljstva zaposlenih pa na konkretno delo oziroma delovno mesto posameznika.

Prvi vprašalnik za merjenje organizacijske klime sta razvila George Litwin in Robert Stringer leta 1968.

Največ raziskav organizacijske klime je bilo izvedenih med letoma 1970 in 1980, po tem obdobju so te raziskave precej manj pogoste. Preučevanje organizacijske klime ni bilo nikoli tako popularno kot raziskave zadovoljstva zaposlenih. Preučevanje organizacijske klime v organizacijah pa je šlo v tri smeri:

- primerjava in celo povezovanje organizacijske klime in organizacijske kulture,

- povezovanje organizacijske klime z zadovoljstvom zaposlenih,

- raziskave organizacijske klime kot povsem samostojne kategorije. 
Koncepta organizacijske klime in organizacijske kulture sta si vsebinsko podobna in na nek način med seboj povezana, vendar sta $\mathrm{v}$ principu povsem različna, ker se navzven različno manifestirata. Eno najbolj celovitih študij o kulturah je opravil Geert Hofstede. Hofstede (2001) pravi, da je kultura kolektivno programiranje uma, ki razlikuje člane ene skupine ali kategorije ljudi od drugih. Svyantek in Bott (2004) sta predlagala opredelitve, ki pomagajo razlikovati med organizacijsko klimo in organizacijsko kulturo. Organizacijska kultura je opredeljena kot skupek skupnih vrednot in norm, ki jih imajo zaposleni. Organizacijska klima pa je bolj vedenjsko usmerjena, je nekaj, kar zaposleni zaznavajo, te zaznave pa za njih predstavljajo »stimulus« oziroma spodbude za ustvarjalnost, inovacije ipd.

$\mathrm{Na}$ nekaterih področjih se obravnava organizacijske klime in organizacijske kulture lahko pokrije prekriva, npr.:

- $\quad$ skupinski kolektivizem (angl. In-Group Collectivism - Collectivism II) je stopnja posameznikove pripadnosti in identifikacije s skupino, družino ali organizacijo,

- usmerjenost $\mathbf{v}$ prihodnost (angl. Future Orientation) predstavlja stopnjo, do katere družba spodbuja in nagrajuje vedenje, ki je usmerjeno v prihodnost (npr. planiranje prihodnosti, investiranje),

- usmerjenost v uspešnost (angl. Performance Orientation) je stopnja, koliko družba ceni in nagrajuje individualne dosežke in odličnost.

$\mathrm{V}$ teh primerih obravnave je organizacijsko klimo mogoče razumeti kot manifestacijo kulture.

Podobno se navzven različno manifestirata zadovoljstvo zaposlenega in organizacijska klima. Kot smo navedli, je za pojmovanje zadovoljstva značilno naslednje:

- $\quad$ zadovoljstvo je čustvo, ki nastane na osnovi zaznavanja dela oziroma delovnega mesta, lahko se manifestira zgolj kot »misel«, lahko pa tudi kot širši odziv telesa, sekundarno pa se lahko manifestira tudi kot ravnanje, 
- fenomen »zadovoljstva« se navzven lahko manifestira kot "zadovoljstvo« ali kot "nezadovoljstvo«, pri čemer dejavniki zadovoljstva in nezadovoljstva niso ene in iste vrste kategorija,

- organizacijska klima pa se nanaša na organizacijo kot celoto in se navzven manifestira $\mathrm{v}$ ravnanje zaposlenega.

Patterson in soavtorji (2005) ugotavljajo, da je bil pri pojmovanju organizacijske klime v vseh teh desetletjih napredek pri razvoju teorije pravzaprav zelo majhen. Pojmovanje dimenzij organizacijske klime se je skozi desetletja namreč le nekoliko spreminjalo. Dunnette, Lawler in Weick (1970) so opredelili štiri dimenzije:

$$
\begin{array}{ll}
- & \text { avtonomija posameznikov, } \\
- & \text { stopnja odgovornosti posameznikov, } \\
- & \text { nagrajevanje uspešnih, } \\
- & \text { podpora. }
\end{array}
$$

Področje zadovoljstva zaposlenih in organizacijske klime je razmejil Muchinsky (1977). Po njegovem mnenju k organizacijski klimi sodijo naslednje kategorije:

- odnos organizacije do posameznikov kot oseb,

- standardi,

- učinkovitost vodenja/organizacije,

- organizacijska struktura in postopki,

- odgovornost,

- identifikacija (poistovetenje) zaposlenih z organizacijo.

$\mathrm{V}$ področje zadovoljstva zaposlenih pa po njegovem mnenju sodijo naslednje kategorije:

- delo oziroma narava dela,

- nadzor,

- plača,

- napredovanja,

- sodelavci (odnosi med sodelavci). 
Muchinsky (1977) je opredelil tudi 16 spremenljivk področja zadovoljstva s komuniciranjem: vpliv, želja po interakciji, natančnost idr.

Gul (2008) pa je prepoznal naslednje dimenzije organizacijske klime: red in disciplina, demokracija, socialni in kulturni dejavniki in image organizacije.

Raziskave organizacijske klime v Sloveniji SiOK so se pod okriljem Gospodarske zbornice Slovenije začele šele od leta 2001.

Po vprašalniku SiOK k organizacijski klimi sodijo ${ }^{1}$ :

- odnos do kakovosti,

- inovativnost, iniciativnost,

- motivacija in zavzetost,

- pripadnost organizaciji,

- notranji odnosi,

- vodenje,

- strokovna usposobljenost in učenje,

- poznavanje poslanstva in vizije ter ciljev,

- organiziranost,

- notranje komuniciranje in informiranje,

- nagrajevanje,

- razvoj kariere.

Vprašanja, vezana na zadovoljstvo zaposlenih, pa se navezujejo na naslednje kategorije zadovoljstva:

- sodelavci,

- stalnost zaposlitve,

- delovni čas,

- narava dela,

- nadrejeni, 
- možnosti za izobraževanje,

- delovnimi pogoji (oprema, prostori),

- status v organizaciji,

- vodstvo organizacije,

- možnosti napredovanja,

- plača.

Vprašalnik SiOK je sicer zanimiv in zelo uveljavljen v praksi, vendar ga ni mogoče obravnavati kot resno referenco, saj ima že v osnovi nekatere temeljne napake in pomanjkljivosti, kot npr.:

- $\quad$ Motivacija in zavzetost ne sodita niti $\mathrm{v}$ kategorijo organizacijske klime niti zadovoljstva, saj npr. zavzetost izhaja iz človeka samega, za razliko od zadovoljstva, ki je čustvo, ki se pojavi na podlagi zaznave zunanjega okolja.

- Vodstvo organizacije za večino zaposlenih pogosto ni objekt zaznave iz fizičnega okolja, $\mathrm{v}$ večjih podjetjih članov uprave večina zaposlenih namreč sploh nikoli osebno ne sreča, torej gre za tipično kolektivno kognicijo.

- Notranji odnosi so tipično področje obravnave zadovoljstva zaposlenih. Muchinsky (1977) je opredelil odnos organizacije do zaposlenih kot atribut organizacijske klime, odnose med zaposlenimi pa kot atribut zadovoljstva zaposlenih.

- Podobno sta plača in možnost napredovanja tipičen atribut zadovoljstva zaposlenih, ne pa organizacijske klime.

\section{Zavzetost (ang1. work engagement)}

Kot smo pokazali, je zadovoljstvo zaposlenega človekov odziv na zaznavo. Zavzetost zaposlenega pa izhaja iz človeka samega. Zavzetost pomeni njegov osebni trud, ki ga vlaga $\mathrm{v}$ delo. Treba je razlikovati med zavzetostjo in zadovoljstvom na delovnem mestu. 
Za prvega, ki je začel znanstveno preučevati zavzetost zaposlenih, velja William Kahn. Kahn (1990) je preučeval, kakšen je odnos med zaposlenimi in njihovimi delovnimi nalogami. Izhajal je iz teorij organizacijskega vedenja iz petdesetih in šestdesetih let prejšnjega stoletja. Preučeval je, ali na osebno zaznavanje pomena dela zaposlenega vplivajo medosebni odnosi, delovna skupina, odnosi $\mathrm{v}$ skupini in kontekst organizacije.

Postavil je dve hipotezi:

- Na vrednote in behaviorizem zaposlenega vplivajo psihološke izkušnje pri delu.

- Na psihološke izkušnje zaposlenega vplivajo: medosebni odnosi, delovna skupina, odnosi v skupini, kontekst organizacije in dejavniki znotraj posameznika.

Opravil je dve vzporedni raziskavi v dveh popolnoma različnih organizacijah:

- v poletnem delovnem kampu, kjer je šest tednov prostovoljno delalo približno 100 mladostnikov;

- $\quad \mathrm{v}$ arhitekturnem biroju, ki je veljal za prestižnega in kjer je bilo zaposlenih 45 ljudi.

Ugotovil je, da je treba zavzetost in nezavzetost zaposlenih obravnavati popolnoma ločeno, ker sta to dve ločeni kategoriji.

Osebna zavzetost je simultan odziv človeka in prednostno odraža človeka samega. Z osebno zavzetostjo človek sam odraža svojo povezanost $z$ delovno nalogo in z ostalimi, ki so s tem v zvezi. Ljudje, ki so zavzeti, imajo v sebi lastnosti, kot so energija, kognitivne sposobnosti ipd. Te se odrazijo v delovnem naporu. Kahn (1990) je nadalje ugotovil, da obstaja tudi povezanost med osebno zavzetostjo in pomenom, ki ga zaposleni pripisuje naslednjim trem dejavnikom:

- smiselnost delovne naloge pomeni »občutek povrnitve vložka v izvedbo delovne naloge«, 
- varnost pomeni občutek ostati zaposlen, brez strahu za zaposlitev, samopodobo in lastno kariero,

- razpoložljivost pomeni imeti fizično energijo, čustva in mentalno energijo, potrebno za izvedbo delovne naloge.

V nasprotju s tem pa osebna nezavzetost pomeni simultan umik človeka samega, avtomatsko obrambno reakcijo in prednostno odraža skrivanje prave identitete.

$\mathrm{Na}$ podlagi te raziskave so bile $\mathrm{v}$ naslednjih letih opravljene številne druge znanstvene raziskave. $\mathrm{V}$ Evropi se je $\mathrm{s}$ tem področjem $\mathrm{v}$ veliki meri ukvarjala Univerza $v$ Utrechtu, še posebej Wilmar B. Schaufeli. Za merjenje zavzetosti zaposlenih je bil razvit poseben model, imenovan Utrecht Work Engagement Scale (UWES), UWES vprašalnik (Schaufeli, Bakker, 2003). UWES vprašalnik ima 17 vprašanj, ki se nanašajo na: psihično moč in energijo ( 6 vprašanj), predanost (5 vprašanj) in absorpcijo ( 6 vprašanj). Psihična moč se odraža v energiji, vloženi v delo, mentalni moči, pozitivnih občutkih do dela, vztrajnosti in odpornosti (na morebitne neuspehe). Predanost se odraža v pomenu, ki ga nekdo pripisuje delu, entuziazmu, navdihu, ponosu na delo in dosežke ter izzivu, ki ga delo nekomu predstavlja. Absorpcija pa se nanaša na to, koliko delo nekoga prevzame, mu je v veselje ipd.

Koncept zavzetosti izhaja iz tako imenovane "pozitivne psihologije«. Je nasprotje konceptu izgorelosti. Psihična moč je nasprotje izčrpanosti. Predanost je nasprotje cinizmu. Absorpcija je nasprotje poklicni (ne)učinkovitosti. Kot pravi Schaufeli (2003), pa to ne pomeni, da med zavzetostjo in izgorelostjo obstaja negativna korelacija. Nekdo je lahko zavzet, vendar ni nujno, da bo tudi izgorel. Po drugi strani pa izgorelost ni nujno posledica zavzetosti.

Svetovalne agencije so kasneje razvile številne komercialne lestvice za merjenja zavzetosti. Ena od najbolj uporabljenih je »Gallupov vprašalnik Q12«. Gallupov pristop na podlagi 12 vprašanj razvrsti zaposlene $\mathrm{v}$ tri kategorije: zavzeti, nezavzeti in aktivno nezavzeti. Pristop razvrščanja zaposlenih v kategorije po Gallupovem vprašalniku Q12 je nekoliko drugačen, kot ga je imel William Kahn. Zaposlene kategorizira v tri skupine in ne v dve. Tretja kategorija zaposlenih po Gallupovem vprašalniku Q12 so »aktivno nezavzeti«. To so tisti, ki aktivno izražajo svoje nezadovoljstvo. 


\section{$4 \quad$ Predlog koncepta anketnega vprašalnika}

\section{Splošna načela}

Ugotavljamo, da podjetja tudi v 21. stoletju še vedno prakticirajo izvajanje anket o zadovoljstvu svojih zaposlenih. Na primeru ankete SiOK ter tudi na primeru nekaterih drugih anket delodajalcev smo prepoznali nekatere slabosti obstoječih anket:

- Ankete kot celota pogosto ne temeljijo na znanstveno preverjenih spoznanjih.

- Vsebine anketnih vprašanj so pogosto preveč splošne in zato premalo uporabne za odločevalski proces. Management sicer dobi neke rezultate, vendar si z rezultati ne more pomagati.

- Formulacije vprašanj so pogosto nedoločljive, včasih ni mogoče vedeti, po čem anketno vprašanje sploh sprašuje. Npr. formulacija »način« ni določljiva, torej se ne ve, kaj pomeni »v naravi«.

- Ponujeni odgovori so praviloma zaprtega tipa, vendar so formulacije nedoločljive (npr. redno, občasno, nikoli omogočajo subjektivne interpretacije, zato je treba izraziti časovne enote, ki so objektivnega tipa).

- Vsebine anket so praviloma asimetrične. Po eni strani se ankete nanašajo na zadovoljstvo, po drugi strani pa ni vprašanj o zavzetosti.

- Vprašanja niso formulirana tako, da bi bil izključen fenomen kolektivne kognicije. Pogosto so ankete smiselne, saj bi enake rezultate dobili, če bi spraševali zgolj mnenjske voditelje. Anketni vprašalnik mora biti formuliran tako, da njegov rezultat odraža osebno izkušnjo oziroma zaznave vprašanega.

- Pogosto ni upoštevano, da so dejavniki zadovoljstva in dejavniki nezadovoljstva dve med seboj različni kategoriji.

Predlagamo, da se pri izvajanju bodočih anket upoštevajo naslednja načela anketiranja:

- zagotavljanje anonimnosti sodelujočih, 
- vsebina anketnih vprašanj naj izhaja iz mednarodno uveljavljenih in znanstveno utemeljenih metod,

- vprašanja in odgovori naj bodo določljivi - torej naj bo vsakomur razumljivo, kaj pomenijo $\mathrm{v}$ naravi,

- vsebina naj bo uravnotežena, kar pomeni, da se vsebine anketnega vprašalnika $\mathrm{v}$ enakem obsegu nanašajo na pravice in na dolžnosti deležnikov.

Predlagamo, da ima anketni vprašalnik naslednje vsebinske sklope:

- zaznana kakovost delovnega okolja,

- organizacijska klima,

- zaznani notranji odnosi,

- organizacijska kultura organizacije,

- zavzetost zaposlenih,

- ocenjevanje managementa,

- ocenjevanje identitete in branda organizacije.

\section{Zaznana kakovost delovnega okolja}

Predlagamo, da se pri opredelitvi vsebin ugotavljanja zadovoljstva načeloma upoštevajo ugotovitve Robertsona. ${ }^{2}$ Predlagamo, da se vprašanja formulirajo kot »zaznana kakovost delovnega okolja«, ne pa kot »zadovoljstvor. Namen izvajanja ankete o zadovoljstvu je pridobiti neko čim bolj objektivno sliko, beseda »zadovoljstvo« pa že sama po sebi generira »socio-emocionalni rezultatk. Treba je torej čim bolj objektivno oceniti, kakšna je dejanska kakovost notranjega okolja v njegovi »fizični« obliki. Ločiti je treba ocenjevanje »fizičnega« okolja (torej sistema) in »socialne interakcije«.

\footnotetext{
2 Robertson, E. (2005). Placing leaders at the heart of organizational communication. Strategic Communication Management. 9(5), 34.
} 
Predlagane vsebine "zaznane kakovosti delovnega okolja« so nekoliko prilagojene po Robertsonu in so:

- zaznana kakovost delovnega okolja, ki se nanaša fizične pogoje dela,

- zaznana kakovost delovnega okolja, ki se nanaša na plačo posameznika,

- zaznana kakovost delovnega okolja, ki se nanaša na možnost kariere posameznika,

- zaznana kakovost delovnega okolja, ki se nanaša na varnost zaposlitve posameznika,

- zaznana kakovost delovnega okolja, ki se nanaša položaj oddelka znotraj organizacije,

- zaznana kakovost neposrednega komuniciranja posameznika z neposredno nadrejenim (pravočasnost informacij, vsebinska popolnost),

- zaznana kakovost delovnega okolja, ki se nanaša na koordiniranje med oddelki.

Tabela1: Predlog vprašalnika za zaznano kakovost delovnega okolja.

\begin{tabular}{|c|c|c|c|c|c|c|c|c|c|c|c|}
\hline $\begin{array}{c}\mathbf{0} \\
\text { nikoli }\end{array}$ & $\begin{array}{c}\mathbf{1} \\
\text { nekajkrat } \\
\text { letno ali } \\
\text { manj } \\
\end{array}$ & $\begin{array}{c}\mathbf{2} \\
\text { enkrat } \\
\text { mesečno } \\
\text { ali manj }\end{array}$ & $\begin{array}{c}2 \\
\text { nekajkrat } \\
\text { mesečno }\end{array}$ & \multicolumn{2}{|c|}{$\begin{array}{c}4 \\
\text { enkrat } \\
\text { tedensko }\end{array}$} & \multicolumn{3}{|c|}{$\begin{array}{c}\mathbf{5} \\
\text { nekajkrat } \\
\text { tedensko }\end{array}$} & \multicolumn{3}{|c|}{$\begin{array}{c}6 \\
\text { vsak dan }\end{array}$} \\
\hline \multicolumn{6}{|c|}{ Fizične pogoje svojega dela zaznavam kot ustrezne. } & & & & & & \\
\hline \multicolumn{5}{|c|}{ Fizične pogoje svojega dela zaznavam kot neustrezne. } & 0 & 1 & 2 & 3 & 4 & 5 & 6 \\
\hline \multicolumn{12}{|c|}{ Zaznavam, da imam ustrezno plačo. } \\
\hline \multicolumn{12}{|c|}{ Zaznavam, da imam prenizko plačo. } \\
\hline \multicolumn{11}{|c|}{ Zaznavam, da imam previsoko plačo. } & \\
\hline \multicolumn{12}{|c|}{ Zaznavam, da imam možnost kariere. } \\
\hline \multicolumn{12}{|c|}{ Zaznavam, da nimam možnosti kariere. } \\
\hline \multicolumn{12}{|c|}{ Zaznavam, da je moja zaposlitev varna. } \\
\hline \multicolumn{12}{|c|}{ Zaznavam, da je varnost moje zaposlitve ogrožena. } \\
\hline \multicolumn{12}{|c|}{ Zaznavam, da je položaj mojega oddelka ustrezen. } \\
\hline \multicolumn{12}{|c|}{ Zaznavam, da položaj mojega oddelka ni ustrezen. } \\
\hline \multicolumn{12}{|c|}{$\begin{array}{l}\text { Zaznavam, da mi nadrejeni daje pravočasne in } \\
\text { vsebinsko popolne informacije. }\end{array}$} \\
\hline \multicolumn{12}{|c|}{$\begin{array}{l}\text { Zaznavam, da mi nadrejeni ne daje pravočasnih in } \\
\text { vsebinsko popolnih informacij. }\end{array}$} \\
\hline \multicolumn{12}{|c|}{ Zaznavam, da oddelki med seboj delujejo koordinirano. } \\
\hline \multicolumn{5}{|c|}{$\begin{array}{l}\text { Zaznavam, da oddelki med seboj delujejo } \\
\text { nekoordinirano. }\end{array}$} & & & & & & & \\
\hline
\end{tabular}




\section{Notranji odnosi}

Zaznana kakovost notranjega okolja ni odvisna samo od »fizikalnih dimenzij«, pač pa je odvisna tudi zaznav medosebnih odnosov. Zato je ločeno treba preučevati tudi ta vidik. Pri preučevanju je treba izhajati iz spoznanj Ashkanasyja in soavtorjev ${ }^{3}$.

Kot smo že pojasnili, so čustva posledica zaznave. Ob obravnavi zadovoljstva na delovnem mestu je torej treba poznati vzrok.

Da bi lažje razumeli pojav čustev, čustva in njihove učinke znotraj organizacije, je Ashkanasy zasnoval 5-stopenjski model. Z modelom lahko določimo, kje in v kakšni obliki so čustva prisotna na delovnem mestu. Stopnje si sledijo (Ashkanasy et al., 2009):

1. stopnja: čustveni procesi na ravni posameznika (obstoječa čustvena stanja; skrita čustva; razpoloženje);

2. stopnja: razlike med posamezniki;

3. stopnja: medosebne interakcije;

4. stopnja: interakcije na ravni skupine (čustvena sestava; čustveno inteligentne skupine; čustvena okužba; odnos nadrejeni - podrejeni);

5. stopnja: interakcije na ravni organizacije.

Čustveni procesi na ravni posameznika so v vprašalniku zajeti v sklopu zavzetosti. Prav tako vprašanja ne obravnavajo organizacije kot celote, ker to sodi v preučevanje organizacijske klime.

\footnotetext{
3 Ashkanasy, Neal M., Dasborough Marie T., Ascough Kaylene W. (2009). Developing Leaders: Teaching about Emotional Intelligence and Training in Emotional Skills. V Steven J. Armstrong in Cynthia V. Fukami (ur.), The SAGE Handbook of Management Learning, Education and Development (str. 161-177). London: SAGE Publications.
} 
Tabela 2: Predlog vprašalnika za oceno notranjih odnosov

\begin{tabular}{|c|c|c|c|c|c|c|}
\hline $\begin{array}{c}\mathbf{0} \\
\text { nikoli }\end{array}$ & $\begin{array}{c}1 \\
\text { nekajkrat } \\
\text { letno ali } \\
\text { manj }\end{array}$ & $\begin{array}{c}2 \\
\text { enkrat } \\
\text { mesečno } \\
\text { ali manj }\end{array}$ & $\begin{array}{c}\mathbf{3} \\
\text { nekajkrat } \\
\text { mesečno }\end{array}$ & $\begin{array}{c}4 \\
\text { enkrat } \\
\text { tedensko }\end{array}$ & $\begin{array}{c}\mathbf{5} \\
\text { nekajkrat } \\
\text { tedensko }\end{array}$ & $\begin{array}{c}6 \\
\text { vsak } \\
\text { dan }\end{array}$ \\
\hline \multicolumn{5}{|c|}{$\begin{array}{l}\text { Zgolj zaradi enega sodelavca sem v službi vesel in dobro } \\
\text { razpoložen. }\end{array}$} & & \\
\hline \multicolumn{5}{|c|}{$\begin{array}{l}\text { Zgolj zaradi enega sodelavca v službi čutim jezo in slabo } \\
\text { razpoloženje. }\end{array}$} & & \\
\hline \multicolumn{5}{|c|}{$\begin{array}{l}\text { Med sodelavci v oddelku se prenaša sodelovanje, } \\
\text { prijateljstvo, dobra volja in pozitivno razpoloženje. }\end{array}$} & & \\
\hline \multicolumn{5}{|c|}{$\begin{array}{l}\text { Med sodelavci v oddelku so osebna rivalstva, medsebojne } \\
\text { zamere in slaba volja. }\end{array}$} & & \\
\hline \multicolumn{5}{|c|}{$\begin{array}{l}\text { Kadar srečam svojega nadrejenega, sem vedno sproščen } \\
\text { (lahko čutim tudi pozitivno energijo). }\end{array}$} & & \\
\hline \multicolumn{5}{|c|}{$\begin{array}{l}\text { Kadar srečam svojega nadrejenega čutim, da nisem } \\
\text { sproščen (lahko čutim tudi negotovost in strah). }\end{array}$} & & \\
\hline
\end{tabular}

\section{Organizacijska klima}

Pri formulacijah vprašanj, vezanih na organizacijsko klimo, smo izhajali iz teoretičnih opredelitev pojma »organizacijska klima«. Po definiciji organizacijsko klimo predstavljajo spodbude za ravnanje, npr. za inovacije. Gre za percepiraje dogajanja, praks in procedur na ravni organizacije.

Tabela 3: Predlog vprašalnika za oceno organizacijske klime

\begin{tabular}{|c|c|c|c|c|c|c|c|c|}
\hline $\begin{array}{c}\mathbf{0} \\
\text { nikoli }\end{array}$ & $\begin{array}{c}\mathbf{1} \\
\text { nekajkrat } \\
\text { letno ali } \\
\text { manj }\end{array}$ & $\begin{array}{c}\mathbf{2} \\
\text { enkrat } \\
\text { mesečno } \\
\text { ali manj }\end{array}$ & $\begin{array}{c}\mathbf{3} \\
\text { nekajkrat } \\
\text { mesečno }\end{array}$ & $\begin{array}{c}\mathbf{4} \\
\text { enkrat } \\
\text { tedensko }\end{array}$ & \multicolumn{2}{|c|}{$\begin{array}{c}\mathbf{5} \\
\text { nekajkrat } \\
\text { tedensko }\end{array}$} & \multicolumn{2}{|c|}{$\begin{array}{c}\text { 6 } \\
\text { vsak } \\
\text { dan }\end{array}$} \\
\hline $\begin{array}{l}\text { Zaznavam, da imamo vsi zaposleni v naši organizaciji } \\
\text { skupno vizijo. }\end{array}$ & & & & & \\
\hline $\begin{array}{l}\text { Zavedam se, kaj je dejavnost naše organizacije in komu je } \\
\text { namenjena. }\end{array}$ & & & & & \\
\hline $\begin{array}{l}\text { Zaznavam, da se v naši organizaciji ceni prispevek k dosegi } \\
\text { skupnih ciljev. }\end{array}$ & & & & & \\
\hline Zaznavam podporo in nagrajevanje dobrih idej. & & & & & & & \\
\hline $\begin{array}{l}\text { V naši organizaciji zaznavam sistemski pristop k poslovanju } \\
\text { in sistematično reševanje problemov. }\end{array}$ & & & & & & \\
\hline Zaznavam, da smo zaposleni usmerjeni v napredek. & & & & & & \\
\hline
\end{tabular}




\section{Organizacijska kultura}

Pri preučevanju organizacijske kulture je treba izhajati iz spoznanj Hofstedeja in raziskave GLOBE.

Geert Hofstede. Hofstede (2001) pravi, da ima kultura družbe šest dimenzij:

Odnos do moči izraža stopnjo, do katere šibkejši člani družbe sprejemajo, da je moč v družbi porazdeljena neenako.

Individualizem oziroma kolektivizem se odraža v opredelitvi človekove samopodobe v smislu »jaz« ali »mi«. Individualizem je družbeni okvir, v katerem je splošno sprejeto in se pričakuje, da bodo posamezniki poskrbeli samo zase. Nasprotje je kolektivizem, v katerem je splošno sprejeto in se pričakuje, da bodo člani skupine $\mathrm{v}$ zameno za nesporno zvestobo poskrbeli za posameznike.

Moškost oziroma ženskost družbe predstavlja kriterij za vrednotenje dosežkov. Moškost v družbi pomeni, da se cenijo dosežki, herojstvo in materialne nagrade za uspehe. Nasprotje je ženskost, kjer se ceni sodelovanje, skromnost in kakovost življenja.

Izogibanje negotovosti izraža stopnjo zaznavanja neugodja $v$ nepredvidljivih, neznanih ali novih okoliščinah. Kulture se med seboj razlikujejo tudi v odnosu do neobičajnega vedenja in do novih idej.

Odnos do prihodnosti predstavlja razmerje med težnjami po ohranjanju tradicije in spremembami.

Tolerantnost oziroma zadržanost pomeni odnos do užitkov. Tolerantna je družba, ki ljudem poleg zadovoljevanja osnovnih življenjskih potreb dopušča tudi užitke in zabavo. V nasprotju družba lahko s strogimi normami užitke in zabavo tudi zavira. 
Atributi kulture družbe po metodologiji GLOBE temeljijo na ugotovitvah Hofstedeja. So pa nekoliko širši in vsebujejo atribute:

1. Odnos do moči je stopnja, do katere se člani organizacije strinjajo, da je moč porazdeljena enakomerno.

2. Izogibanje negotovosti je obseg, v katerem se člani organizacije trudijo izogniti negotovosti prihodnjih dogodkov.

3. Družbeni kolektivizem je stopnja, do katere organizacija ceni povezovanje v skupine.

4. Skupinski kolektivizem je stopnja izražanja pripadnosti organizaciji.

5. Enakopravnost spolov je stopnja, do katere organizacija omogoča enakopravnost med spoloma.

6. Odpornost je stopnja, do katere se od posameznikov pričakuje tekmovalnost v medsebojnih odnosih.

7. Usmerjenost $\mathbf{v}$ prihodnost je stopnja, do katere se posamezniki $\mathbf{v}$ organizaciji vključujejo $\mathrm{v}$ procese, kot sta načrtovanje in vlaganje $\mathrm{v}$ prihodnost.

8. Usmerjenost $\mathbf{v}$ uspešnost je stopnja, do katere organizacije nagrajujejo člane skupine za izboljšanje uspešnosti.

9. Človečnost je stopnja, do katere se nagrajuje posameznike za poštenost, nesebičnost in velikodušnost.

\section{Zavzetost zaposlenih}

Predlagamo uporabo:

- $\quad$ vprašalnika Utrecht Work Engagement Scale (UWES) ali

- Gallupovega vprašalnika Q12. 


\section{Ocenjevanje managementa}

Pri ocenjevanju managementa je treba izhajati iz kriterijev objektivnega tipa.

V predlogu smo izhajali iz opredelitev (McKnight, 2013).

Predlagamo štiri dimenzije:

- Ustreznost se odraža v skrbi za osebni videz, v primernem obnašanju in v socialnih spretnostih.

- Zaupanje se odraža v pravilnosti odločitev in ravnaj z vidika spoštovanja zakonov, etike in družbenih norm.

- Kompetence so znanja, spretnosti, navade ter prirojene zmožnosti. Odražajo se v profesionalnosti ravnanja.

- Konsistentnost je doslednost ravnanja skozi daljše časovno obdobje.

Tabela 4: Predlog vprašalnika za oceno neposrednega vodje

\begin{tabular}{|c|c|c|c|c|c|c|c|c|c|c|}
\hline $\begin{array}{c}\mathbf{0} \\
\text { nikoli }\end{array}$ & $\begin{array}{c}1 \\
\text { nekajkrat } \\
\text { letno ali } \\
\text { manj }\end{array}$ & $\begin{array}{c}2 \\
\text { enkrat } \\
\text { mesečno } \\
\text { ali manj }\end{array}$ & $\begin{array}{c}2 \\
\text { nekajkrat } \\
\text { mesečno }\end{array}$ & $\begin{array}{c}4 \\
\text { enkrat } \\
\text { tedensko }\end{array}$ & & jkra & & & $\mathrm{k}$ & \\
\hline \multirow{2}{*}{\multicolumn{5}{|c|}{$\begin{array}{l}\text { Zaznavam, da vodja skrbi za svoj osebni videz, se } \\
\text { primerno obnaša in ima socialne spretnosti. } \\
\text { Zaznavam, da se vodja neprimerno obnaša in nima } \\
\text { socialnih spretnosti. }\end{array}$}} & 1 & 2 & 3 & 4 & 5 & \\
\hline & & & & & & & & & & \\
\hline \multicolumn{5}{|c|}{$\begin{array}{l}\text { Zaznavam, da se vodja odloča pravilno in } z \text { vidika } \\
\text { spoštovanja zakonov, etike in družbenih norm ravna } \\
\text { pravilno. }\end{array}$} & & & & & & \\
\hline \multicolumn{5}{|c|}{$\begin{array}{l}\text { Zaznavam, da se vodja odloča napačno in ne spoštuje } \\
\text { zakonov, etike ter družbenih norm. }\end{array}$} & & & & & & \\
\hline \multicolumn{5}{|c|}{$\begin{array}{l}\text { Zaznavam, da vodja ravna profesionalno, da ima znanja, } \\
\text { spretnosti, navade ter prirojene zmožnosti. }\end{array}$} & & & & & & \\
\hline \multicolumn{5}{|c|}{$\begin{array}{l}\text { Zaznavam, da vodja ravna neprofesionalno, da nima } \\
\text { znanja, spretnosti, navad ter prirojenih zmožnosti. }\end{array}$} & & & & & & \\
\hline \multicolumn{5}{|c|}{ Zaznavam, da vodja ravna dosledno. } & & & & & & \\
\hline \multicolumn{5}{|c|}{ Zaznavam, da vodja ravna nedosledno. } & & & & & & \\
\hline
\end{tabular}




\section{Ocenjevanje branda in identitete organizacije}

Identiteta organizacije je vse tisto, kar organizacija $\mathrm{v}$ resnici je in kar je $\mathrm{v}$ zvezi z organizacijo možno zaznati. Skozi zgodovino so se pokazali številni primeri človeških skupnosti, ki bi bili brez identitete skupnosti nezmožni golega preživetja.

Že zaradi oblikovanja skupne identitete je treba postaviti tudi vprašanja o notranji percepciji branda organizacije in si prizadevati za skupno identiteto.

Brand organizacije pa se nanaša na organizacijo kot celoto. Je kolekcija vseh zaznanih podob, ki so jih o organizaciji ljudje zaznali od preteklosti do sedanjosti (McKnight, 2013).

Balmer in Greyser (2013) navajata naslednja vprašanja identitete organizacije:

- Katere so glavne značilnosti organizacije?

- S kom in v zvezi s čim mora organizacija komunicirati?

- Kaj je poslanstvo organizacije in s čim je organizacija zavezana okolju?

- Kaj povezuje člane organizacije in do česa imajo člani organizacije afiniteto?

- Kako je bila organizacija skozi čas percepirana v okolju?

- Kako je organizacija v okolju percepirana danes?

Obravnavane dimenzije branda organizacije so ${ }^{4}$ :

- Zaupanje je prepričanje, da bo organizacija izpolnila svoje obljube do strank.

- Integriteta je prepričanje v pošteno obravnavo in rešitev problemov, ki bi se utegnili pojaviti s strankami.

- Ponos je manifestacija osebne povezanosti uporabnika z blagovno znamko.

- Strast je prepričanje, da je blagovna znamka nenadomestljiva.

${ }^{4}$ Povzeto po: http://www.dialogos.si/slo/objave/clanki/zavzetost/ 
Tabela 5: Predlog vprašalnika za oceno branda organizacije:

1 - sploh se ne strinjam; 2 - se ne strinjam; 3 - ne morem se opredeliti; 4 - strinjam se; 5 - zelo se strinjam.

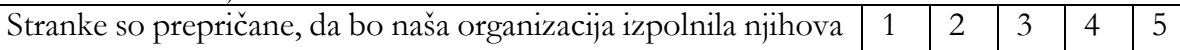
pričakovanja.

Stranke so prepričane $\mathrm{v}$ pošteno obravnavo in rešitev problemov.

Stranke so ponosne, da so stranke prav naše organizacije.

Stranke so prepričane, da je naša organizacija nenadomestljiva.

Tabela 6: Predlog vprašalnika za oceno identitete organizacije

\begin{tabular}{|c|c|c|c|c|c|c|c|c|c|c|c|}
\hline $\begin{array}{c}\mathbf{0} \\
\text { nikoli }\end{array}$ & $\begin{array}{c}1 \\
\text { nekajkrat } \\
\text { letno ali } \\
\text { manj }\end{array}$ & $\begin{array}{c}2 \\
\text { enkrat } \\
\text { mesečno } \\
\text { ali manj }\end{array}$ & $\begin{array}{c}2 \\
\text { nekajkrat } \\
\text { mesečno }\end{array}$ & $\begin{array}{c}4 \\
\text { enkrat } \\
\text { tedensk }\end{array}$ & & & $\begin{array}{l}5 \\
\text { ajk } \\
\text { ens }\end{array}$ & & & $\mathrm{kc}$ & \\
\hline \multicolumn{5}{|c|}{$\begin{array}{l}\text { Zaznavam, v katere cilje je usmerjeno delovanje našega } \\
\text { oddelka in kaj je »centralni fokus« oddelka. }\end{array}$} & 0 & 1 & 2 & 3 & 4 & 5 & 6 \\
\hline \multicolumn{6}{|c|}{$\begin{array}{l}\text { Zaznavam, da smo v prizadevanjih za dosego skupnih } \\
\text { ciljev našega oddelka enotni vsi zaposleni v oddelku. }\end{array}$} & & & & & & \\
\hline \multicolumn{6}{|c|}{$\begin{array}{l}\text { Zaznavam, da v prizadevanjih za dosego skupnih ciljev } \\
\text { celotnega podjetja nismo enotni, da obstaja upiranje in } \\
\text { boj za prevlado. }\end{array}$} & & & & & & \\
\hline \multicolumn{6}{|c|}{$\begin{array}{l}\text { Zaznavam, } v \text { katere cilje je usmerjeno delovanje } \\
\text { celotnega podjetja in kaj je »centralni fokus« podjetja. }\end{array}$} & & & & & & \\
\hline \multicolumn{6}{|c|}{$\begin{array}{l}\text { Zaznavam, da smo v prizadevanjih za dosego skupnih } \\
\text { ciljev podjetja enotni vsi zaposleni v podjetju. }\end{array}$} & & & & & & \\
\hline \multicolumn{5}{|c|}{$\begin{array}{l}\text { Zaznavam, da v prizadevanjih za dosego skupnih ciljev } \\
\text { podjetja nismo enotni, da obstaja upiranje in boj za } \\
\text { prevlado. }\end{array}$} & & & & & & & \\
\hline
\end{tabular}

5

Zaključek

Poskusi v tovarni Western Electric v kraju Hawthorne so imeli izjemno velik vpliv na razvoj teorije in prakse kadrovskega managementa. Nobenega dvoma ni, da z vidika današnjega časa interpretacija velja za problematično. Prav po tej raziskavi je poimenovan fenomen Hawthornov učinek, ko sodelujoči v poskusih prilagodi svoje obnašanje, ker se zaveda, da je opazovan. 
Vendar so ti poskusi z današnje perspektive zanimivi predvsem zato, ker je šlo za zelo napredno tovarno IKT opreme. V tovarni so izdelovali komponente in opremo za telefonijo (releje, telefonske centrale ipd.). Poskusi so potekali v zvezi z delovnimi operacijami adjustaže kontaktnih blazinic relejev, montaže vezij oziroma žičnih oblik ipd. Ta tehnologija je bila aktualna do izuma mikroprocesorja. Za tisti čas je bilo to nekaj podobnega, kot če bi danes preučevali robotizirano tovarno mobilnih telefonov. S perspektive današnjega časa je takratna tehnologija že vsaj 40 let popolnoma zastarela. Podobno velja za tehnološke postopke. Zaključimo lahko, da take raziskave danes $\mathrm{v}$ enakih okoliščinah praktično ni več mogoče ponoviti.

$\mathrm{Na}$ zelo podoben način funkcionira fenomen, imenovan Hawthornov učinek. Gre za to, da se obnašanje udeležencev eksperimenta spremeni, če se udeleženi zavedajo, da se jih opazuje.

Zaključki poskusov v tovarni Western Electric so torej preveč problematični, da bi bili $\mathrm{v}$ 21. stoletju še vedno predmet učnih programov fakultet kadrovskega managementa. Če pa že so, potem je potrebno zraven vsaj omeniti vse okoliščine.

Ali je torej koncept merjenja zadovoljstva pri delu preživet? Odgovor je, da ni. Merjenje zadovoljstva zaposlenih $\mathrm{v}$ današnjem času ni preživeto, vendar se je spremenila vsebina zadovoljstva, spremenil pa se je tudi namen merjenja. Danes obstajajo številne pravne norme in mednarodne konvencije, ki se nanašajo na pravice delavcev. Prav tako obstajajo tehnični standardi in standardi varovanja zdravja pri delu. Vsaj v naših krajih torej ne bi smelo biti vprašanje, ali bo delavec dobil plačo ali ne, ali bo imel odmor za malico ali ne ipd. (čeprav vemo, da obstajajo tudi anomalije). Prav tako ne bi smelo biti vprašanje ustreznosti fizičnih pogojev dela. Vsebine, vezane na zakonite pravice delavcev v 21. stoletju, ne bi smele biti predmet preučevanja zadovoljstva.

Drugo vprašanje pa so socialne interakcije, ki jih ni mogoče normirati. Vemo, da imajo posledice nezadovoljstva pri delu vpliv na počutje in tudi na zdravje. Kaj pa pravzaprav je tisto, kar na to vpliva? 
Kot pravi Storozhuk (2010), človeško telo s svojimi čutili vsako minuto zazna okoli 10.000 zaznav. Zaznave so hkratne in imajo različne pojavne oblike: vizualne zaznave, zaznave zvoka, vonja, temperature, okusa, bolečine in prostorskega položaja telesa (ravnotežja). Človeško telo je pri zaznavanju treba obravnavati kot enovito celoto. Zgolj oko spremeni svoj položaj vsakih 150-200 ms. Torej se v očesu vsak dan pojavi 216.000 vizualnih zaznav. Nemogoče je za vsakega posameznika vedeti, katera zaznava bo povzročila neko čustvo.

Kljub temu pa je pri raziskovanju in pri vsakodnevni managerski praksi treba ločiti nekatere osnovne pojme. Za managerja je pomembno vedeti, kaj je tisto, na kar lahko vpliva. Temu morajo slediti tudi merjenja fenomenov klime, zavzetosti in zadovoljstva. Tudi v 21. stoletju so merjenja potrebna, izvesti pa jih moramo na tak način, da bodo imeli rezultati $\mathrm{v}$ primeru ugotovljenih potreb po izboljšavah delovnega ali organizacijskega okolja za managerje uporabno vrednost.

\section{Literatura}

Ashkanasy, N. M., Dasborough, M. T., Ascough K. W. (2009). Developing Leaders: Teaching about emotional Intelligence and Training in Emotional Skills. V: Armstrong, S. J. in Fukami, C. V. (ur.), (2009) The SAGE Handbook of Management Learning, Education and Development (str. 161-177). London: SAGE Publications.

Azash, S., Thirupalu, N. (2017). Scale for measuring jobsatisfaction - a review of literature. EPRA International Journal of Economic and Business Revie, 5(3), 114-123.

Balmer, J. M. T., Greyser, A. S. (2013). Revealing the Corporation. Routledge: London.

Bendaly, N. (2019). The Results Are In, And Current Employee Engagement Strategies Aren't Working: Here's What Does, Fobes, $7 . \quad 9.2019$, https://www.forbes.com/sites/nicolebendaly/2019/09/07/the-results-are-in-currentemployee-engagement-strategies-arent-working-heres-what-does/\#4894b09940f9

Brayfield, A. H., \& Rothe, H. F. (1951). An index of job satisfaction. Journal of Applied Psychology, 35(5), 307-311.

Brissette, I., \& Cohen, S. 2002. The contribution of individual differences in hostility to the associations between daily interpersonal conflict, affect, and sleep. Personality and Social Psychology Bulletin, 28: 1265-1274.

Brower, A. M., Nurius, P. (1993). Social Cognition and Individual Change: Current Theory and Counseling Guidelines. Sage: London.

Bullock, R. P. (1952). Socal Factors relating to Job satisfaction. Ohio State University, Bureau of Business Research: Columbus.

De Risio, A. (2014). Social Cognition. Everyday Problems and Working Capacity in Persons with Schizophrenia : Outcomes from the Real World. objavljeno v: Nasato, S. R. (2014). Advances in Social Cognition Research. Nova Science Publishers: New York.

Demerouti, E., Bakker, A. B., Nachreiner, F., \& Schaufeli, W. B. (2001). The job demands

Franke, R. H. \& Kaul, J. D. (1978). The Hawthorne experiments: First statistical interpretation. American Sociological Review, 43, 623-643.

Freudenberger, N. J. (1974). Staff burnout. Journal of Social Issues, 30, 159-165. 
Goldstein, E. B. (2009). Sensation and Perception. Cengage Learning.

Goldstein, E. B. (2010). Encyclopedia of Perception. SAGE: Thousand Oaks.

Gu, Yuanbo; Wang, Ruimei; You, Xuqun.(2020). Recovery Experiences Moderate the Impact of Work Stressors on Well-Being: A Two-Wave Study of Preschool Teachers. Early Childhood Education Journal. 48 (2), 189-202.

Gul, H. (2008). Organizational Climate and Academic Staff's Perception on Climate Factors, Humanity \& Social Sciences Journal 3 (1), 37-48.

Härtel, C. E. J., Zerbe, W. J. , Ashkanasy, N. M. (2015). New Ways of Studying Emotions in Organizations. Emerald: Bingley.

Hayes, M., Chumney, M., Wright, C., Buckingham, M. (2019) Global Study of Engagement, The'Technical Report, The ADP Research Institut, https://www.adp.com//media/adp/resourcehub/pdf/adpri/adpri0102_2018_engagement_study_technical_report_ release $\% 20$ ready.ashx

Herzberg, F.(reprint 2003). One More Time: How Do You Motivate Employees? in Harvard business review 81(1), 87-96.

Hofstede, G. (2001). Culture's Consequences: Comparing Values, Behaviors, Institutions and Organizations Across Nations. 2nd Edition. Sage: Thousand Oaks.

Hulin, C. L., \& Judge, T. A. 2003. Job attitudes:A theoretical and empirical review. In W. C. Borman, D. R. Ilgen, \& R. J. Klimoski (Eds.), Handbook of psychology, Hoboken, NJ: Wiley.

Ingram, R. (2015). Understanding Emotions in Social Work: Theory. Practice and Reflection. McGraw-Hill: Berkshire.

Izawa, M. R., French, M. D., Hedge, A. (2011). Shining New Light on the Hawthorne Illumination. Experiments. Human Factors: The Journal of the Human Factors and Ergonomics Society. 53(5), 528-547.

Kahn, W. A. (1990). Psychological conditions of personal engagement and disengagement. Academy of Management Journal, 33(4), 692-724.

Kelly, J (2019). More Than Half Of U.S. Workers Are Unhappy In Their Jobs: Here's Why And What Needs To Be Done Now, 25.10.2019, https://www.forbes.com/sites/jackkelly/2019/10/25/more-than-half-of-us-workers-areunhappy-in-their-jobs-heres-why-and-what-needs-to-be-done-now/\#5e5cee302024

Kitchener, R. F., O'Donohue. W. T. (1999). Handbook of Behaviorism. Academic Press: San Diego.

Kohll, A. (2018): What Employees Really Want At Work, Forbes, 10.7.2018, https://www.forbes.com/sites/alankohll/2018/07/10/what-employees-really-want-atwork/\#66db5ddd5ad3

Kristensen, T., Borritz, M., Ebbe Villadsen, E., \& Christensen, K. (2007). The Copenhagen Burnout Inventory: A new tool for the assessment of burnout. An International Journal of Work. Health \& Organisations. 19(3), 192-207.

Kruse, K. (2012). What Is Employee Engagement. Forbes. 22.7 .72012 , https://www.forbes.com/sites/kevinkruse/2012/06/22/employee-engagement-what-andwhy/\#5837be0b7f37

Litwin, G., Stringer R. ( 1968). Motivation and Organizational Climate, Harvard University Press: Cambridge.

Lobnikar, B. (2016). Krepitev delovne zavzetosti zaposlenih-naloga vodij, https://www.um.si/kakovost/usposabljanje-

zaposlenih/Lists/Usposabljanja2/Attachments/43/Krepitev\%20delovne $\% 20$ zavzetosti $\% 20 \mathrm{z}$ aposlenih $\% 20 \% 20$ naloga $\% 20$ vodij\%20UM.pdf

Locke, A. E. (1969). What is job satisfact i on? Organizational Behavior and Human Performance, 4, 309-33.

Locke, E. A. (1976). The Nature and Causes of Job Satisfaction. In M. D. Dunnette (Eds.),Handbook of industrial and Organizational Psychology (1297-1349). Chicago: RandMcNally.

Mannevuo, M. (2018). The riddle of adaptation: Revisiting the Hawthorne studies. The Sociological Review. January 19, 2018. Dostopno na: 
https://doi-org.ezproxy.lib.ukm.si/10.1177/0038026118755603

Marcum, J. A. (2014). Theory of Everything Cognitive: from Neurons to Extended Cognition. Objavljeno v: Rosenfield, E. P. (2014). New Developments in Cognitive Systems Research. Hauppauge. Nova Science Publishers: New York.

Maslach, C. \& Jackson, S. E. (1981). The measurement of experienced burnout. Journal of Occupational Behaviour, 2 (2), 99-113.

Mayo, E. (1933). The human problems of an industrial civilization. Macmillan Company: new York.

McKnight, D. A. (2013). The Zen of executive presence. DAMStyle: Cleveland.

Muchinsky, P. (1977): Organizational Communication: Relationships to Organizational Climate and Job Satisfaction .Academy of Management Journal. 20 (4), 592-607.

Ottaviani, C., Shapiro, D., Goldstein, I., Gofman, V. (2012). Personality Traits and Daily Moods. Objavljeno v: Arroyo, D., Delgadillo, E. (2012: Encyclopedia of Personality Research. Nova Science: New York.

Pallesen, S. (2009). A new scale for measuring insomnia: The Bergen Insomnia Scale. Perceptual and Motor Skills. 107(3), 691-706.

Parsons, H. M. (1974). "What happened at Hawthorne?: New evidence suggests the Hawthorne effect resulted from operant reinforcement contingencies". Science. 183 (4128): 922-932.

Patterson, M., West, M., Shackleton, V., Dawson, J., Lawthom, R., Maitlis, S., Robinson, D., Wallace, A. (2005). Validating the organizational climatemeasure: links to managerial practices, productivity and innovation. Journal of Organizational Behavior, 26, 379-408.

Pennington, D. C. (2000). Social Cognition. Routledge: London.

Poghosyana, L., Aikenb, L., \& Sloaneb, D. (2009). Factor structure of the Maslach burnout inventory: An analysis of data from large scale cross-sectional surveys of nurses from eight countries. International Journal of Nursing Studies, 46, 894-902.

Robbins, S. P. (2005). Organizational behavior. UpperSaddle River. Prentice-Hall. New Jersey.

Robertson, E. (2005). Placing leaders at the heart of organizational communication. Strategic Communication Management. 9(5), 34.

Schaufeli, W. B., Bakker, A. B. (2003). Utrecht Work Engagement Scale. Utrecht University: Utrecht.

Scott, B., Judge, T. (2006). Insomnia, Emotions, and Job Satisfaction: A Multilevel Study. Journal of Management, 32(5), 622-645.

Smith, P. C., Kendall, L., \& Hulin, C. (1969). The Job Descriptive Index Bowling Green. OH. Department of sychology: Bowling Green State University.

Smith, P. C., Kendall, L. M., \& Hulin, C. L. (1969). Themeasurement of satisfaction in work and retirement. McNall: Chicago.

Svyantek, D. J., \& Bott, J. P. (2004). Organizational culture and organizational climate measures: an integrativereview. In J. C. Thomas (Ed.) ,Comprehensive handbook of psychological assessment: Industrial and organizational assessment. (507-524). Wiley Hoboken: New Jersey.

Tagiuri, R. (1968). The concepts of Organizational climate. Harward University Press: Cambridge.

Tagiuri, R., Litwin, H., Barnes, L. (1968). Organizational climate: explorations of a concept. Harvard University. Harvard.

Totterdell, P., Reynolds, S., Parkinson, B., \& Briner, R. B. (1994). Associations of sleep with everyday mood, minor symptoms and social interactions. Sleep, 17, 466-475.

Ubrbrock, R. S. (1934). Attitudes of 4430 employees. The Journal of Social Psychology. 5(3), 365-377.

Westfall, C. (2019):The Future Of Work: Survey Shares New Ideas For Fighting Turnover, Disengagement And Frustration. Forbes. 28. 10. 2019, https://www.forbes.com/sites/chriswestfall/2019/10/28/future-of-work-survey-sharesnew-ideas-employee-engagement-satisfaction/\#6b32ee5a1ceb

Yavuz, G., \& Dogan, N. (2014). Maslach Burnout Inventory-Student Survey (MBI-SS): A Validity Study. Procedia- Social and Behavioral Sciences, 116, 2453-2457.

http://globeproject.com/

http://www.biro-praxis.si/kako-merimo-organizacijsko-klimo-in-zadovoljstvo.html

http://www.dialogos.si/slo/objave/clanki/zavzetost/ 


\title{
Procesno usposabljanje
}

\section{INOVATIVNIH KADROV, RAZVOJ}

\section{MAKSIMALNEGA INDIVIDUALNEGA}

\section{POTENCIALA}

\author{
IZTOK PODBREGAR, ANTONIA NOVAK IN \\ POLONA ŠPRAJC \\ Univerza v Mariboru, Fakulteta za organizacijske vede, Kranj, Slovenija. \\ E-pošta: iztok.podbregar@um.si, antonia.novak@student.um.si,polona.sprajc@um.si
}

Povzetek S kakršnokoli dejavnostjo se ukvarjamo, se lahko zgledujemo po športnih organizacijah, $\mathrm{v}$ katerih je uspeh $\mathrm{v}$ celoti neposredno odvisen od kakovosti posameznih talentov. Umetnost je ugotoviti, katerih znanj nam $\mathrm{v}$ organizaciji primanjkuje, jih s pomočjo analitike pokriti, omogočiti okolje maksimalnega razvoja ter izuriti vsakega posameznika v stratega, ki v krizah kreativno in motivirano podaja rešitve. $V$ raziskavi je bilo anketiranih 200 Slovencev, zaposlenih v Avstriji. Z raziskavo smo pridobili vpogled $\mathrm{v}$ glavne dejavnike, ki zagotavljajo lojalnost tujemu delodajalcu. Osredotočamo se na trenerski stil vodenja, na najnovejše znanstvene izsledke ter $\mathrm{v}$ nadaljevanju na procesno usposabljanje posameznikov. Celovita individualna obravnava ter usposabljanje po procesni metodi dela sta ključ do samozavestnih in inovativnih kadrov, ki bodo svoj potencial razvili na maksimum ter občutno pripomogli $\mathrm{k}$ učinkovitosti podjetja. Vodilna trenerska vloga je nekaj, kar živimo, in je po delovniku ne odložimo. Spretnosti učinkovitega trenerja imajo izjemno vrednost trajnosti tako zasebno, $\mathrm{v}$ osebnih odnosih kot tudi v delovnih odnosih. $\mathrm{V}$ raziskavi bomo prikazali dejstva, ki vplivajo na lojalnost 200-tih Slovencev avstrijskemu delodajalcu. $\mathrm{V}$ analizi bomo predstavili proces zdravstvene nege včasih in danes ter strukturo uporabili za individualno obravnavo, plan usposabljanja zaposlenih.

Ključne besede: manager, analitično zaposlovanje, trenersko vodenje, procesno usposabljanje zaposlenih, razvoj maksimalnega potenciala. 


\section{Process Training of}

INNOVATIVE STAFF, DEVELOPMENT OF MAXIMUM INDIVIDUAL POTENTIAL

IZTOK PODBREgAR, ANTONIA NOVAK \& POLONA ŠPRAJC University of Maribor, Faculty of Organizational Sciences, Kranj, Slovenia.
E-mail: iztok.podbregar@um.si, antonia.novak@student.um.si, polona.sprajc@um.si Abstract Whatever activity we are engaged in, we can follow the example of sports organizations in which success depends entirely on the quality of individual talents. The art is to determine which skills we lack in the organization, to cover them with the help of analytics, to enable an environment of maximum development and to train each individual as a strategist who creatively and motivated provides solutions in crises. In the survey, 200 Slovenes employed in Austria were included. The research provided insight into the main factors that ensure loyalty to a foreign employer. We focus on the coaching style of leadership, on the latest scientific findings and then on the

Keywords: manager, analytical employment, coaching management, process training of employees, development of maximum potential. process training of individuals. Comprehensive individual treatment and training according to the process method of work is the key to self-confident and innovative staff who will develop their potential to the maximum and significantly contribute to the efficiency of the company. The leading coaching role is something we live in and we don't put it off after work. The skills of an effective coach have the exceptional value of sustainability both privately, in personal relationships as well as in work relationships. 


\section{Uvod}

Aktualna problematika poslovanja, ki jo tudi EU postavlja v ospredje, se osredotoča na prepoznavanje, spodbujanje in vključevanje raznolikosti talentov ter na zagotavljanje okolja, v katerem jih zaposleni lahko najbolje razvijajo. Manager je v prvi vrsti osredotočen na svoje zaposlene, kajti to bo zagotovilo uspešen rezultat. Managerji prihodnosti so kreativni, usmerjeni v spremembe, radovedni, odprtega uma, znajo ustvariti delovno okolje, ki stimulira zaposlene, da vložijo svoj maksimum. Naloga managerja je izuriti strateško razmišljajoče odgovorne posameznike, ki znotraj tima sodelujejo in svobodno podajajo svoje ideje, so pripravljeni na nepričakovane situacije $\mathrm{s}$ kreativnim iskanjem rešitev in $\mathrm{v}$ novih zahtevah vidijo nove izzive, nove zmage, predvsem pa rezultate in učinkovitost delovanja. Prikazali bomo načrt za razvoj inovativnih kadrov. Ljudje so bili in so še danes navajeni rutine, tiho slediti, namesto da bi izrabili svoj maksimalni potencial in tako obogatili družbeno premoženje. Situacijska teorija poudarja, da mora podjetje razviti optimalno stopnjo prilagodljivosti na situacijske spremenljivke: tj. na tehnologijo, okolje, velikost podjetja, cilj, strategijo in vodilno - ZAPOSLENE. Kadri so najpomembnejše premoženje, ki ga organizacija ima, in njihovo učinkovito upravljanje je ključ do njenega uspeha. Zaposleni so najpomembnejši del organizacije, razlikujejo se po osebnosti, sposobnostih, delovnih vrednotah, občutenju in razpoloženju pri delu (Podbregar, 2019). Organizacija mora obvladati upravljanje, ki bo ob inovativnem prilagajanju na nenehne spremembe $\mathrm{v}$ okolju ohranilo notranjo učinkovitost, harmonijo ter zadovoljne in motivirane ljudi. Lojalnost zaposlenih je dosegljiva s podporo vodstva pri doseganju osebnih ciljev (Novak, Podbregar, 2019). Dotaknimo se analitičnega pristopa zaposlovanja. Čustvom in intuiciji se je mogoče izogniti pri zaposlovanju nam manjkajočih talentov ter tako privarčevati dragoceni čas z dejstvi, točnimi statističnimi podatki, ki nam jih nudi analitika. Primer, kako izboljšati kadrovanje z analizo kandidatov, prikazuje metoda Moneyball, revolucionarna v športni zgodovini ameriškega baseballa. $\mathrm{Na}$ podlagi razpoložljivih finančnih sredstev je glavni manager ekipe Oakland Athletics, Billy Bean, leta 2003 reorganiziral moštvo in zaposlil le »trgu še nepoznane, neuveljavljene« športnike. Zanašal se je na mnenje statističnega analitika, ki ga je v ta namen zaposlil. Izbrala sta igralce na podlagi njihovih talentov - tj. odličnih individualnih statističnih rezultatov ( $\mathrm{v}$ nižjih ligah, na fakultetah itd.), in sicer za vsako igralsko pozicijo posebej. Moštvo je v prihajajoči sezoni z zadnjega mesta $\mathrm{v}$ ligi postalo konkurenčno vodilnemu moštvu New York Yenkees, ki so imeli na 
razpolago 125 milijonov USD, Oakland pa le 35 milijonov USD. Prvič v zgodovini je moštvo Oakland Athletics zmagalo 20 zaporednih tekem in postavilo rekord v ameriški ligi.

Predstavimo najnovejše znanstvene izsledke modernega upravljanja s kadri, ki zagotavljajo uspeh. Prevedli in povzeli smo spletni članek, objavljen 11. 9. 2019 na ameriški spletni strani, ki deluje kot globalna podpora managerjem s številnimi razvitimi platformami za učinkovito vodenje: www.officevibe.com. Kako postati trener, ki smo si ga vedno želeli imeti. Nazorno prikazana aktualna spoznanja med tradicionalnim hierarhičnim načinom vodenja ter sodobnim načinom treninga: angl. Boss vs. Coach; Šef proti trenerju. Če pogledamo na našo dosedanjo kariero, je zagotovo nekdo pustil velik vtis na nas: mentor, učitelj, nekdanji šef ... Če smo imeli srečo, smo jih srečali tudi več, ne samo enega. Naučili so nas ne samo učne snovi, temveč motivirali, kako se razviti v najboljšo različico sebe tako na profesionalni kot osebni ravni. Opogumili so nas, da razmišljamo s svojo glavo, iščemo svoje rešitve in sprejemamo zmeraj nove izzive, bili so trenerji, ki so nam spremenili življenje. Ni pomembno, ali smo na poziciji višjega managerja ali pa smo pravkar pričeli delovati kot vodje, odločilnega pomena je implementirati trenersko vodenje $\mathrm{v}$ svoj stil vodenja. Bistvo učinkovitega delovanja je, da se naučimo, kako trenirati svoje zaposlene in ne samo vladati oz. ukazovati. Manager mora uskladiti cilje podjetja z osebnimi cilji posameznika, s skupno vizijo visoke učinkovitosti na obeh področjih. Odlični vodje in trenerji dajejo prednost opolnomočenju zaposlenih z občutkom odgovornosti in lastništva, kar jih spodbuja $\mathrm{k}$ iskanju priložnosti, namesto da bi nastopali kot vratarji, ki stojijo med zaposlenimi in njihovo rastjo. Sodobna delovna sila hrepeni po uspešnosti in učinkovitosti. Založba Gallup (2019) je v globalni raziskavi odkrila, da je prvi razlog za menjavo službe "priložnost za poklicno rast«, ta rast pa je neposredno povezana s tem, kako vodja vodi in trenira svojo ekipo, da doseže svoj maksimalni potencial. Z aktivnim spodbujanjem zaposlenih, da rastejo, trenersko vodenje pomaga ustvariti lojalno, produktivno in osredotočeno delovno okolje. Medtem ko mentorstvo omogoča vodjam in zaposlenim, da skupaj sodelujejo pri prepoznavanju, razumevanju in premagovanju zaznanih vprašanj ali težav, ki jih ovirajo, lahko deluje le, če so vsi vpleteni na krovu in so pripravljeni sprejeti ta odnos med trenerjem in zaposlenim. Obstaja veliko različnih stilov vodenja in ne bi predpostavljali, da je en slog objektivno boljši od drugega. Vsak slog deluje različno glede na ekipo, okoliščine in cilje, trenersko vodenje je vsekakor na varni strani in zajema dva stila: določevanje ritma je slog, ki postavlja cilje na podlagi 
produktivnosti, rezultatov in učinkovitosti za celotno ekipo; pripadnostni slog vodenja se osredotoča na ustvarjanje harmonije in miru znotraj ekipe, pri čemer daje prednost čustvenim povezavam med člani ekipe. S kombinacijo obeh stilov vodenja trenerji prevzemajo odgovornost in spodbujajo zaposlene $\mathrm{k}$ določitvi in doseganju njihovega potenciala, hkrati pa prispevajo $\mathrm{k}$ večjim ciljem ekipe in ustvarjajo harmonijo personaliziranega postavljanja ciljev in kariere.

Delo na lastni čustveni inteligenci je mandat sodobnega vodstva, rezultat so trajni in uspešni odnosi, ki temeliijo na zaupanju. Premik iz tradicionalnega managementa v trenersko vodenje $\mathrm{z}$ močnejšimi metodami zagotavlja razvoj delovne sile $\mathrm{v}$ maksimalno učinkovitost. Ne poudarja samo ciljev in števil, temveč se osredotoča na človeka in mu omogoči razmere, $\mathrm{v}$ katerih lahko upravlja svoj maksimalni potencial. Stéphanie Leblanc, »superzvezdnica« med managerji Officevibe, odgovorna za 17 zaposlenih, na vprašanje, kaj pomeni biti trener, odgovori: »Moj stil treniranja in vodenja je neposreden odraz tega, kako globoko skrbim za člane svoje ekipe« Trenerska miselnost je miselnost za ljudi. Učimo se, kaj v resnici poganja ljudi, $\mathrm{v}$ čem so dobri, kaj v resnici radi počnejo in kdaj čutijo, da so na nekaj najbolj vplivali. Potrebno je veliko zaupanja in spoznati svoje zaposlene kot ljudi.

\section{$2 \quad$ Metodologija}

Kombinacija kvalitativnih in kvantitativnih metod raziskovanja, področje raziskovanja je internacionalno, usmerjeno na slovenske kadre, aktivne $\mathrm{v}$ tujini in Sloveniji. Posluževali smo se aplikacij moderne tehnologije in prebiranja strokovne literature. $V$ teoretičnem delu se osredotočamo na trenerski stil vodenja in analitični način zaposlovanja, $\mathrm{v}$ raziskovalnem delu prikazujemo dejansko sliko kompetenc zaposlenih $\mathrm{v}$ različnih profitnih družbah, zavedanje pomembnosti svoje vloge $\mathrm{v}$ podjetju, sodelovanje pri sprejemanju odločitev, vključevanje talentov in osebno zadovoljstvo ter lojalnost $\mathrm{v}$ aktualni organizaciji, kjer so zaposleni. Končno prikazujemo celovito obravnavo posameznikov po procesni metodi dela. Torej obravnavo kontinuiranega individualnega usposabljanja, ki privede do učinkovitega tima, polnega talentov s skupno vizijo, ki motivirano in inovativno išče rešitve ob spoprijemanju z nepričakovanimi spremembami. 


\section{$3 \quad$ Raziskava}

Predstavljamo aktualno situacijo delovnih razmerij pri tujem delodajalcu, vključevanje talentov, sodelovanje pri sprejemanju odločitev podjetja, zavedanje pomembnosti svoje vloge ter prikaz lojalnosti zaposlenih aktualnemu delodajalcu. Vzorec: 200 Slovencev, zaposlenih na avstrijskem tržišču. Obširno raziskavo smo izvedli, ker so nas zanimale njihove delovne izkušnje.

V prispevku smo ciljno prikazali le nekaj vprašanj, ki z aktualnimi dejstvi podkrepijo naš tokratni predmet zanimanja. Celotna raziskava s podrobnimi statističnimi analizami, izračuni in razčlenitvami je prikazana $\mathrm{v}$ magistrskem delu: »Lojalnost zaposlenih je dosegljiva s podporo vodstva pri doseganju osebnih ciljev« (Novak, Podbregar, 2019).

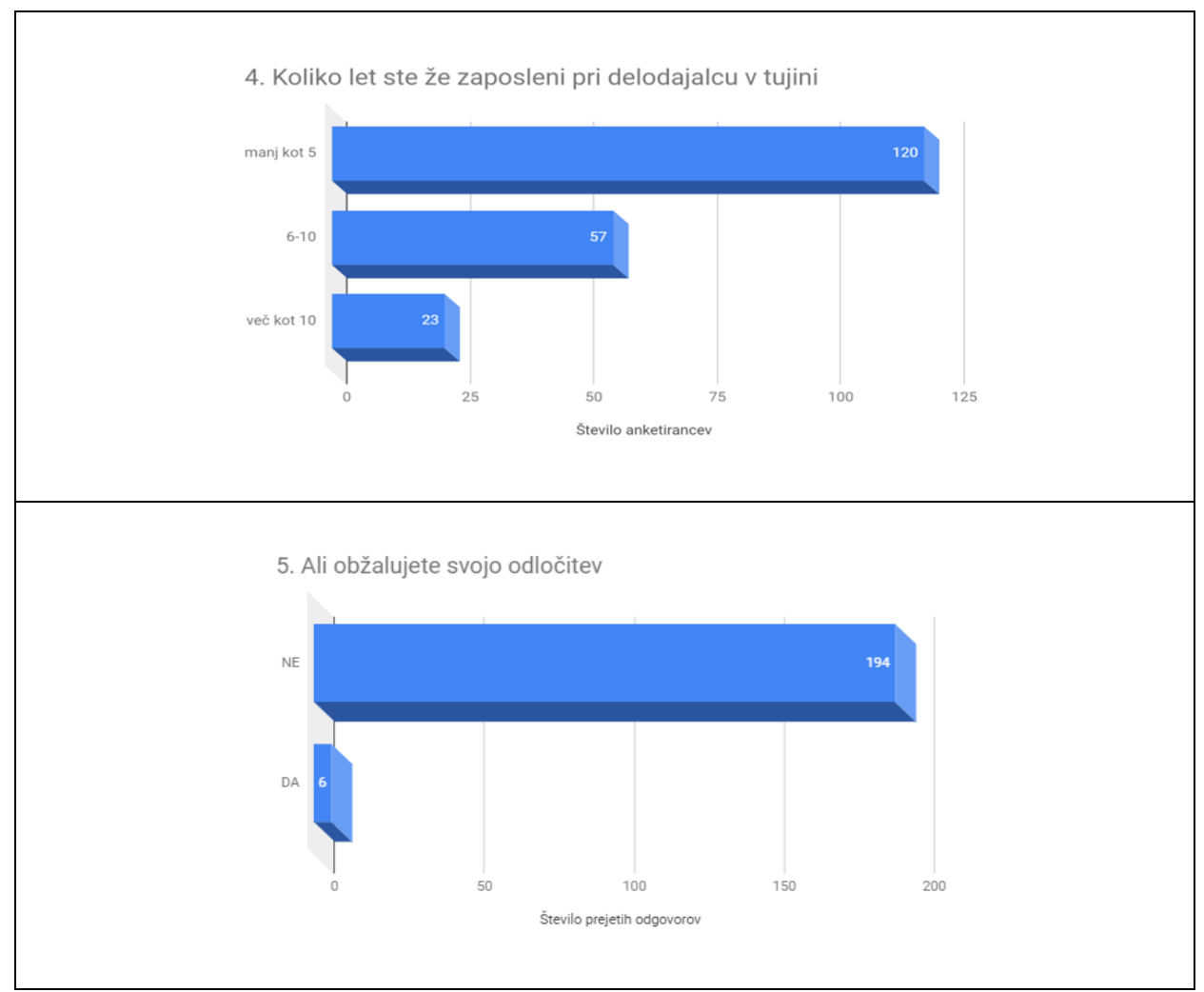

Slika 1: Grafični prikaz preštetih prejetih odgovorov na prikazana vprašanja naše ankete 
Razberemo: 120 od 200 anketirancev je pri tujem delodajalcu zaposlenih manj kot 5 let, 57 jih je obkrožilo 6-10 let, 23 pa jih je preseglo 10 let delovne dobe v Avstriji. Svoje odločitve o sklenitvi čezmejnega delovnega razmerja nikakor ne obžalujejo, kar potrjuje 194 od 200 anketirancev.

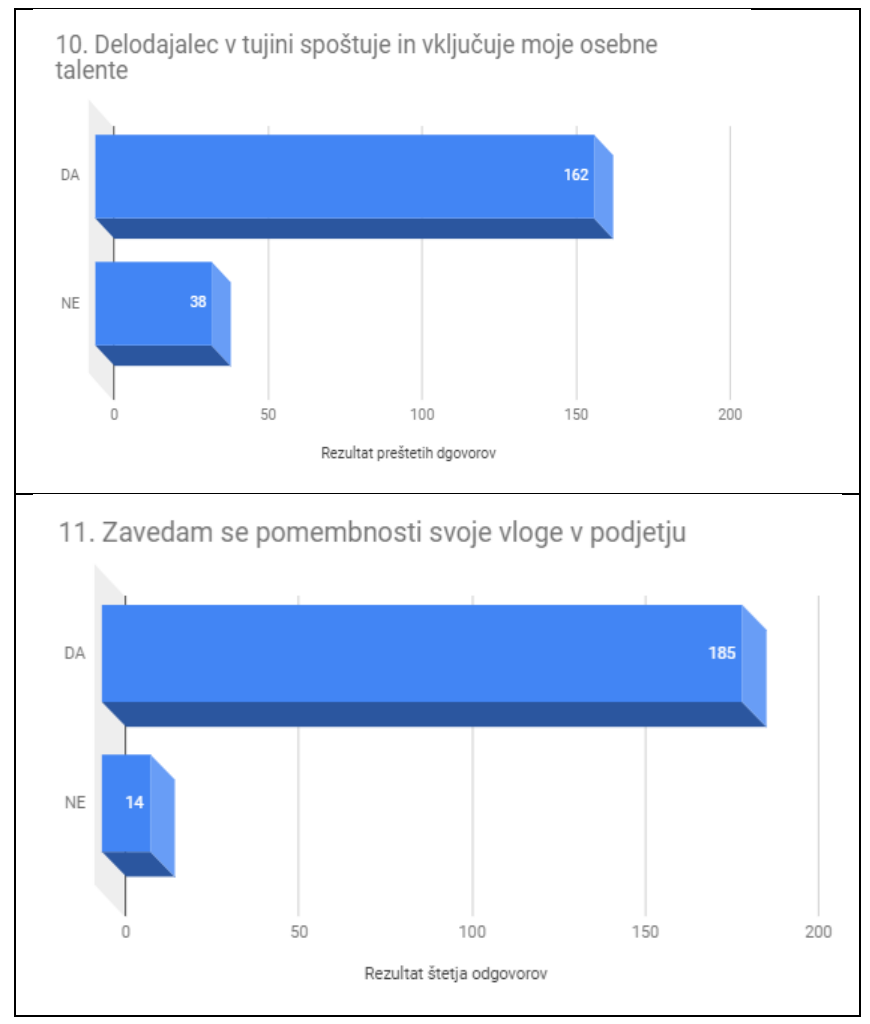

Slika 2: Grafični prikaz preštetih prejetih odgovorov na prikazana vprašanja naše ankete

Razberemo: velika večina je na obe zastavljeni vprašanji odgovorila z DA. Torej 162 anketirancev potrjuje, da tuji delodajalec spoštuje in vključuje osebne individualne talente v delovni proces. 185 anketirancev se pomembnosti svoje vloge v podjetju zaveda. 


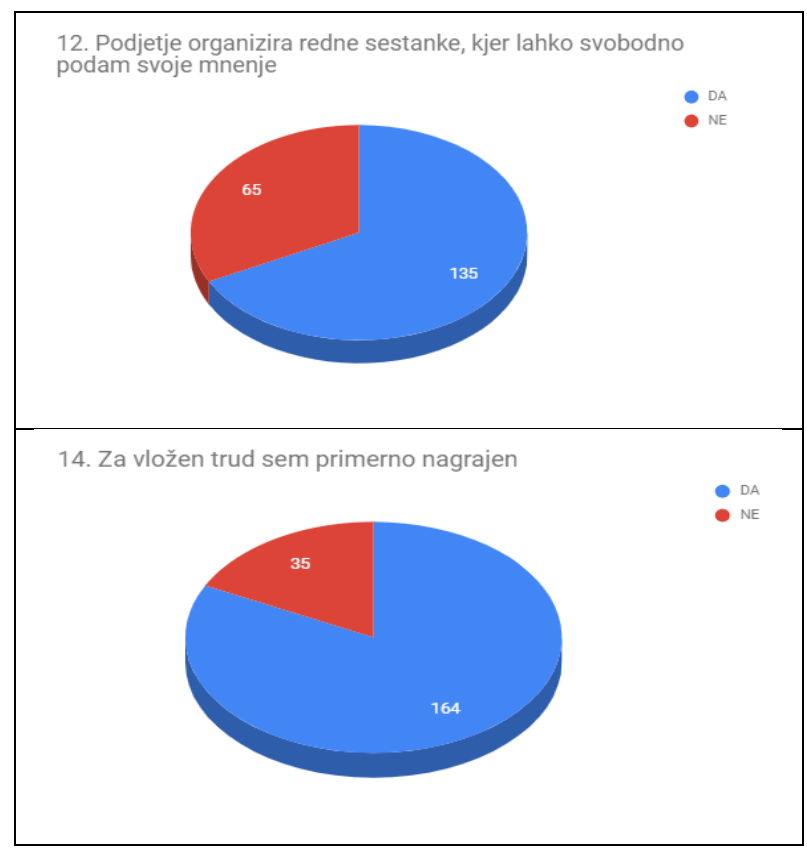

Slika 3: Grafični prikaz preštetih prejetih odgovorov na prikazana vprašanja naše ankete

Ponovno razberemo, da je velika večina anketiranih odgovorila z DA. 135 jih potrjuje, da redno sodelujejo na sestankih podjetja, kjer lahko svobodno izražajo svoje mnenje in ideje, sodelujejo v procesu odločanja. 164 anketiranih trdi, da so primerno nagrajeni za vložen trud.

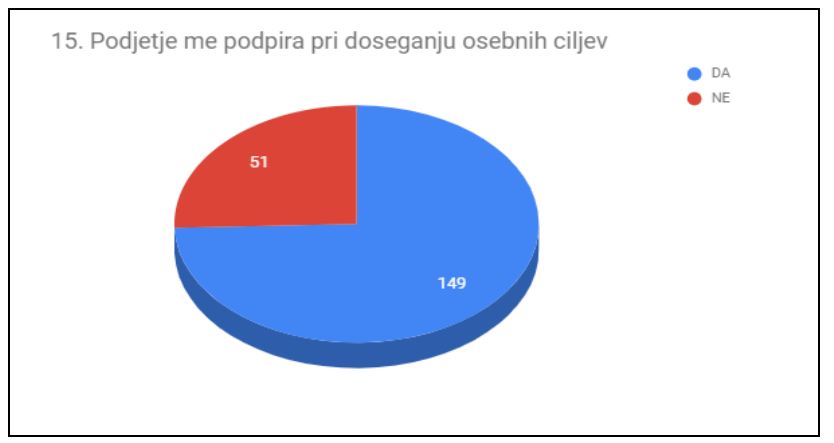




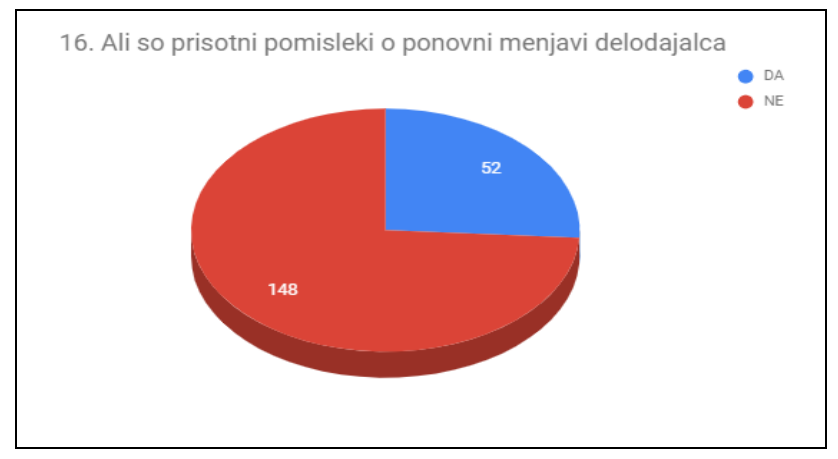

Slika 4: Grafični prikaz preštetih prejetih odgovorov na prikazana vprašanja naše ankete

Velika večina anketirancev potrjuje, da jih podjetje podpira pri doseganju osebnih ciljev. Zadnje vprašanje se nanaša na lojalnost tujemu delodajalcu, saj so anketiranci pred tem razmerjem dosegli različno dolge delovne dobe pri slovenskem delodajalcu. 148 jih potrjuje, da o menjavi aktualnega delodajalca v Avstriji ne razmišlja.

Zanimala nas je moč povezave merjenih spremenljivk, ki odločilno vplivajo na to, da Slovenci ostajajo lojalni tujemu delodajalcu. Izračun je pokazal, da imata najmočnejšo, zelo visoko povezavo z delovno dobo v Avstriji dve spremenljivki: »vključevanje in spoštovanje osebnih talentov« in »podjetje me podpira pri doseganju osebnih ciljev«. Prišli smo do zaključkov, da lojalnost zaposlenih lahko dosežemo, če zagotovimo: podporo vodstva pri doseganju osebnih ciljev; spoštovanje in vključevanje osebnih individualnih talentov; dovolj prostega časa, ki ga zaposleni potrebuje za rehabilitacijo; psihološko varnost na delovnem mestu; urjenje strategij spoprijemanja s stresom.

\section{$4 \quad$ Analiza}

Najpomembnejši viri za organizacijo so ljudje: njihovo znanje, individualne vrednote, kompetence, delovne izkušnje, pripadnost in motiviranost za doseganje skupnih ciljev, fleksibilnost, sposobnost adaptacije in vzpostavljanja dobrih medsebojnih odnosov. Če vzpostavimo psihofizično ravnovesje posameznika, smo naredili nekaj, kar ima neopisljiv pomen za njegovo življenje. Prepričani smo, da bo takšen zaposleni ostal iskren in da bo hrepenel po tem, da bi naredil vse, kar je $\mathrm{v}$ njegovi moči, da bi dosegel oziroma presegel cilje organizacije (Novak, Podbregar, 2019). Manager mora zagotoviti okolje, v katerem se bo vsak posameznik izuril v 
najboljšo različico sebe in tako neprecenljivo prispeval $\mathrm{k}$ doseganju ciljev podjetja. Izpostavimo procesno metodo dela, ki se je za doseganje ciljev podjetja poslužujejo različne profesije. Osebno jo dolga leta poznamo iz prakse v zdravstveni dejavnosti. Strukturo procesa zdravstvene nege (PZN) bomo tokrat uporabili kot podlago usposabljanja inovativnih kadrov. Menimo, da usposabljanje zaposlenih po procesni metodi dela zagotavlja celovito, kvalitetno obravnavo ter razvoj maksimalnega individualnega potenciala.

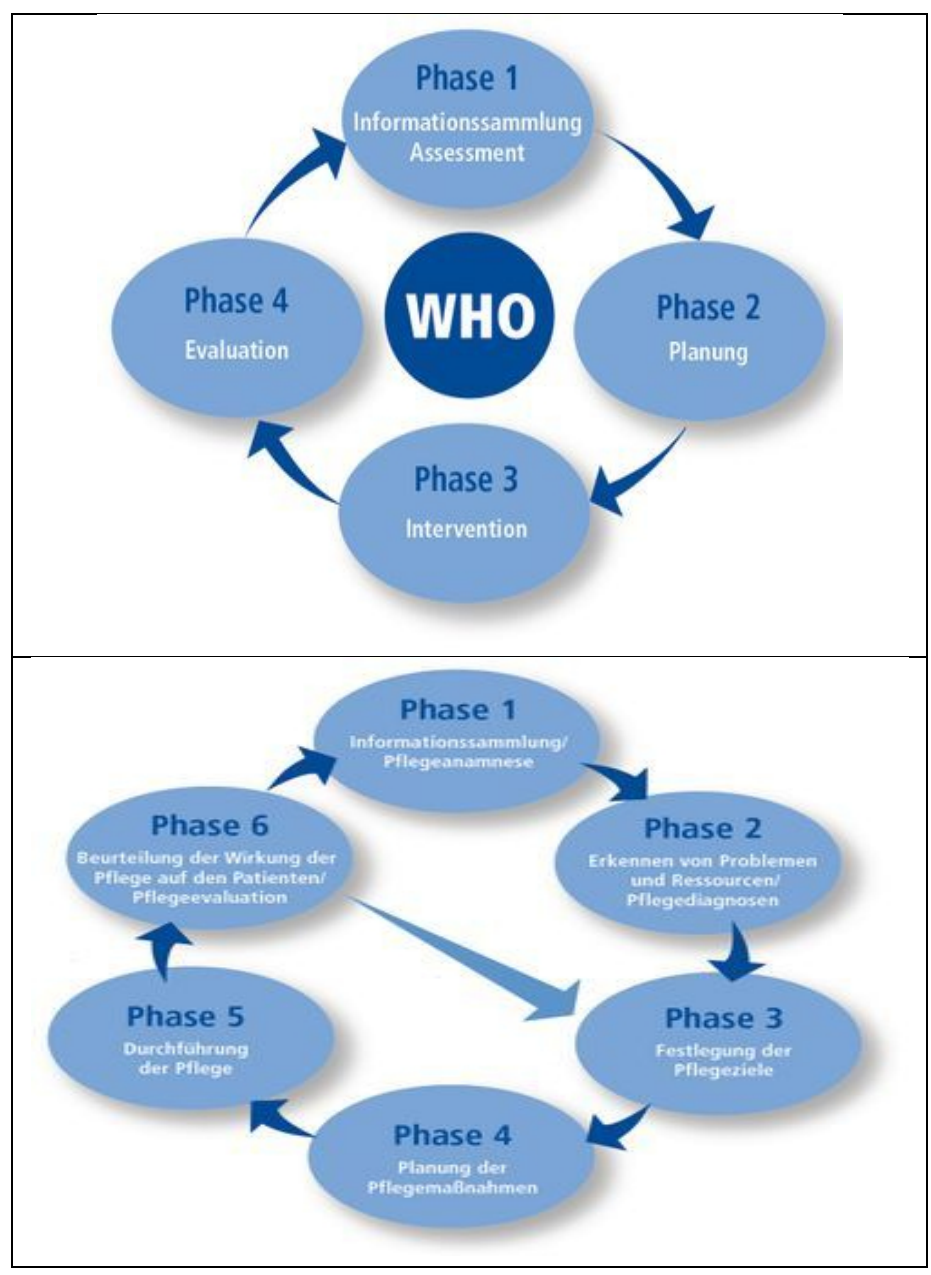

Slika 5: Faze procesa zdravstvene nege

(Vir: https://sabinehindrichs.vpweb.de/dokumentation-strukturmodell ) 
Slika 5 prikazuje osnovni model PZN, sestavljen iz 4 faz, kot ga je leta 1974 potrdila WHO (Worlds Health Organisation - Svetovna zdravstvena organizacija), ter aktualizirani model PZN, ki se uporablja od leta 1998 - sestavljen iz 6 faz. V bistvu ostaja koncept dela nespremenjen, le faze so dodatno razčlenjene. Vse so bile prisotne že v prvi različici, le da so bile podtočke posameznih faz. Prvotne 4 faze PZN: ugotavljanje, načrtovanje, izvajanje in vrednotenje. Faza ugotavljanja obsega anamnezo za ugotovitev dejanskega stanja: opazovanja, meritve, pogovori s pacientom, člani družine, specialisti, negovalnim timom. Poročilo prikaže negovalne probleme, diagnoze, ki jih rangiramo po nujnosti obravnave. Faza načrtovanja: zastavljanje željenih ciljev ter potrebnih intervencij, upoštevanje mnenj specialistov in resursov, ki jih imamo na razpolago, in oblikovanje optimalnega individualnega načrta merljivih intervencij, ki definira izvajanje: KAJ, KDAJ in KDO. Faza izvajanja: vsebuje odgovornost, strokovnost, kontinuirano izvajanje - realizacijo planiranih intervencij, kooperacijo $\mathrm{z}$ drugimi strokovnimi službami, sprotno dokumentiranje. Faza vrednotenja: sprotno in končno vrednotenje; sprotno je pomembno, saj ob neuspešnih intervencijah privede do spremembe plana, prilagoditve za boljši rezultat; končna pa zaključuje proces - potrjuje uspeh našega načrta in nas popelje spet nazaj na prvo fazo, kjer se osredotočamo na novo problematiko. Aktualnih 6 faz PZN: prvo fazo so razširili na tri faze; zastavljeni cilji so sedaj tam, kjer je bila prej faza izvajanja; četrta faza je planiranje (prej druga faza), šele peta izvajanje in šesta vrednotenje. Osebno nam je originalna poenostavljena shema bolj pri srcu, po tej bomo izdelali individualni načrt usposabljanja, ki sledi. Odličen sistem za kvalitetno reševanje nastalih problemov, ki ga lahko uporabimo na vseh življenjskih področjih, tudi za urjenje zaposlenih. Procesno usposabljanje je najbolj učinkovita metoda doseganja optimalnih rezultatov, najprej individualnih, ki posledično botrujejo razvoju maksimalnega ustvarjanja v timu. Poznamo veliko vrst usposabljanj, tukaj se bomo osredotočali na razvoj maksimalnega potenciala posameznikov. Pri izdelavi individualnega plana se bomo zgledovali po zgoraj predstavljenih fazah PZN. Faza ugotavljanja: omogočiti moramo zaupanje vsakega zaposlenega, ga osebno spoznati: njegove talente, osebne cilje, osnovne potrebe, kaj mu je pomembno in seveda predstaviti cilje organizacije. Dobiti je treba vpogled v njegovo družinsko situacijo, obveznosti zunaj delovnega mesta, navade pri delu, njegovo razmišljanje, komuniciranje. Skupaj moramo ugotoviti, kako vključiti njegove individualne sposobnosti in kakšno okolje potrebuje za harmonično produktivno delovanje. Izdelava pisnega poročila nam omogoča izločiti izpostaviti področja, kjer zaposleni potrebuje našo podporo in pomoč, postavimo torej 
diagnoze, ki jih bomo z realizacijo plana odpravili. Faza načrtovanja: izdelamo plan $\mathrm{z}$ željenimi cilji in intervencijami, ki so potrebne za realizacijo, upoštevamo razpoložljive resurse. Planiramo usposabljanje posameznika za percepcijo sedanjega trenutka, fleksibilnega razmišljanja, zdravega načina življenja ter samozavestnega iskanja rešitev na nenehne spremembe iz okolja. Naši cilji so trenirati in usposobiti zaposlenega $\mathrm{v}$ najboljšo različico sebe ter doseči optimalno stopnjo samoupravljanja: ravnovesje med delom in igro, kdaj odklopiti od delovne naloge, kako doseči maksimalno produktivnost našega intelekta, kdaj se ponovno lotiti delovne naloge, kako se umiriti in odklopiti (tehnike meditacije, sproščanja, sprehod v naravo ...), kako se odzivati na stresne situacije (»Coping" strategije), kako obogatiti delovanje tima. Vse planirane intervencije so časovno določene, merljive in fleksibilne prilagodljive posamezniku. Faza izvajanja: zaposlenim nudimo varno psihološko okolje, kjer bodo brez pomislekov razvili zaupanje, nas kadarkoli prosili za nasvet ali podporo, razvili hvaležnost in posledično lojalnost, saj se zavedajo, kaj imajo. Nudimo podporo pri realizaciji osebnih ciljev, vključujemo individualne talente $\mathrm{v}$ naše delovne naloge in zaposlenim omogočamo sodelovanje pri odločanju. Za vložen trud so ustrezno nagrajeni in javno pohvaljeni. Pri realizaciji plana se vsaka intervencija sprotno dokumentira, in če opazimo nepričakovana odstopanja, prilagodimo plan - torej intervencije tako, da bodo cilji realizirani. Intervencije, ki so potrebne za optimalni razvoj zaposlenega, so treningi, kjer se posameznik izoblikuje in pridobi potrebno motivacijo in moči, ki jih je potreboval. Povezujemo se interdisciplinarno: s psihologi, z zdravniki, osebnimi trenerji, motivatorji in drugimi specialisti, ki so potrebni za reševanje obstoječe problematike pri zaposlenem. Faza vrednotenja: $v$ zaključni fazi procesa vrednotimo realizacijo planiranih intervencij in dosežene cilje. Evalvacijo delimo na sprotno vrednotenje, omenili smo ga že v prejšnji fazi, odgovorno za nepričakovane spremembe plana ob slabih rezultatih, ter končno vrednotenje, ki zaključuje proces usposabljanja. Izoblikujemo močnega stratega, ki je pripravljen vložiti svoje maksimalne zmogljivosti $\mathrm{v}$ podjetje in inovativno podajati rešitve na nepričakovane situacije.

Treniranje zaposlenih, ki dosegajo manj od pričakovanega: Če imamo zaposlenega, ki le s težavo opravlja delovne naloge, trenersko vodenje omogoča razumevanje njegovih težav, veščin, sposobnosti, odnosa in rezultatov. Ta vpogled nam služi za izdelavo individualnega načrta, kjer bodo usklajeni njegovi individualni cilji s cilji našega podjetja. Manager si mora vzeti čas in razumeti, zakaj ima zaposleni 
težave pri izvajanju delovnih nalog, kaj mu predstavlja problem, in najti najboljšo možno rešitev za skupno odpravo nastale problematike.

V novi prelomni publikaciji Gallup z naslovom »Its the manager« delijo seznam koristnih vprašanj, $\mathrm{s}$ katerimi lahko vodimo naše trenerske pogovore ter odkrivamo in krepimo adute zaposlenih: Kakšni so Vaši nedavni uspehi? $\mathrm{Na}$ kaj ste najbolj ponosni? Katere nagrade in priznanja so Vam najbolj pomembna? Kako pomembna je Vaša vloga pri doseganju ciljev? Kako bi Vam bilo všeč narediti še večjo spremembo? Kako v trenutni vlogi, tj. na delovnem mestu, uporabljate svoje adute? Kako bi radi uporabili svoje adute $\mathrm{v}$ prihodnosti? Kakšna znanja in veščine potrebujete, da napredujete $\mathrm{v}$ naslednjo fazo kariere?

\section{$5 \quad$ Diskusija}

Kako izbrati pravega sodelavca za naš uspešni tim? Uspešni sodelavci predstavljajo konkurenčno prednost podjetja. Profesionalna selekcija kadrov je pomembna iz številnih razlogov: fluktuacija je za podjetje draga, uvajanje novih sodelavcev je dolgotrajen postopek, če smo izbrali neustreznega kandidata, prihaja do nezadovoljstva z obeh strani, kar negativno vpliva na doseganje rezultatov dela. Da bi se izognili nevšečnostim in prihranili dragoceni čas, se poslužujemo že v procesu zaposlovanja statističnih analiz in metod kadrovskega inženiringa. HR strokovnjaki (Vir: http://www.kadrovsko-svetovanje.si) prevzamejo odgovornost za: zaposlitvene intervjuje s prijavljenimi kandidati, izdelavo pisnega poročila razgovorov in osebno predstavitev kandidatov; svetovanje pri odločitvi kadrov, za katere se profesionalna selekcija nadaljuje; drugi krog razgovorov poteka s predstavnikom podjetja (naročnika), na podlagi katerega se pripravi ožji izbor kandidatov, ki ustrezajo pričakovanjem; "assessment« oz. svetovanje dodatnega testiranja kandidatov: skupinsko reševanje nalog, ki se jih določi glede na pričakovane kompetence, ki naj bi jih kandidati imeli za uspešno vključitev v delovno skupino. Če se naročnik ne odloči za »assessment«, strokovnjaki svetujejo dodatni usmerjeni intervju s kandidatom, psihološko testiranje. Gre za posredovanje strokovno utemeljenih rezultatov v pisni obliki. Končna odločitev je naročnikova, končni skupni posvet s HR strokovnjakom. Trenersko vodenje se razlikuje od drugih stilov, ima pa lastnost, ki je skupna vsem: »Tudi najboljši trenerji potrebujejo svojega trenerja.«Potrebujemo osebo oz. skupino, na katero se lahko zanesemo, prosimo za nasvet in podporo. To je odličen vir informacij, nov pogled na reševanje zahtevnih 
težavnih situacij, podpora izkušenih ljudi, ki delijo delovno etiko in vrednote. Vloga managerja je vzpostaviti psihološko varno delovno okolje. Osredotočati se mora bolj na učenje, manj na izvrševanje, spodbujati eksperimentiranje, pokazati radovednost, priznati lastne napake, sprejeti nelagodje, kontinuirano skrbeti za notranjo harmonijo podjetja - enak način ne ustreza vsem zaposlenim, se poglobiti in prilagoditi »handling«. Usposabljanje definitivno zahteva svoj čas in veliko truda, je nedvomna garancija za razvoj maksimalnega potenciala in produktivnosti zaposlenih. Manager je odgovoren, da omogoča in dopušča inovativnost, potisne zaposlene čez njihove osebne meje in jih podpira pri doseganju osebnih ciljev - tako bo dosegel lojalnost vsakega posameznika. Spoznanja zgoraj prikazanih analiz in naše raziskave potrjujejo, da se celovita kontinuirana skrb za svoje zaposlene še kako izplača. Procesno usposabljanje vsakega posameznika je pot do uspeha. Uspešno zaključena zadnja faza procesa: usposobljen posameznik, neprecenljiva dodatna vrednost našega tima. Pripravljeni smo na zmage, imamo inovativen uspešen tim.

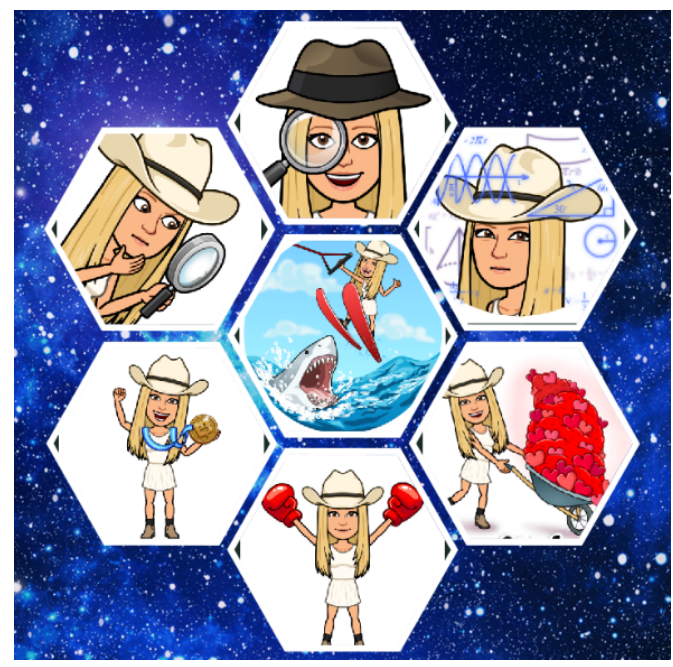

Slika 6: Procesna metoda usposabljanja zaposlenih

Vir: lastni

Kot zanimivost naj omenimo strategijo upravljanja kadrov pri podjetju Google, ki svojim zaposlenim nudi na svojem ogromnem zemljišču vse, kar potrebujejo: zdravnika, zobozdravnika, lekarne, športne površine, avtopralnico, čistilnico, tri obroke dnevno, velnes centre in letno približno 100.000 ur masaž. Gre za prepletanje 
interesov zaposlenih in vodstva. Podjetja $z$ urejenimi kadrovskimi procesi so finančno uspešnejša, motiviranost zaposlenih pa je bistvena (Novak, Podbregar, 2019). Prepričani smo, da prihodnost konkurenčnosti na trgu pripada podjetjem, ki bodo najbolj uspela motivirati zaposlene, jih nenehno usmerjati k učenju, širjenju znanja, tako bodo ohranila konkurenčnost na trgu in postala poznana po svojem upravljanju - kar bo pritegnilo najbolj sposobne ljudi, da bi se tukaj zaposlili.

\section{Literatura}

Cava, R. (2003). Kako se sporazumevati s težavnimi ljudmi: tehnike za obvladovanje stresnih situacij. Založba GANEŠ, Kranj.

Clifton, J., Harter, J. (2019). It's the manager: Gallup finds the quality of managers and team leaders is the single biggest factor in your organization's long-term success; based on our largest global study of the future of work. Gallup Press, ZDA.

Evans, R., Russell, P. (1992). Ustvarjalni manager. Alpha center, Ljubljana.

Florjančič, J. (1999). Planiranje in razvoj kadrov. Moderna organizacija, Kranj.

Gamsjäger, T. (2019). Meditation für Berufstätige - Das Sofort System: Wie du mit minimalem Zeitaufwand die Gelassenheit und innere Stärke erlangst, von der du immer geträumt hast. Amazon Distribution, independently published.

Goleman, D. (2008). Čustvena inteligenca. Mladinska knjiga, Ljubljana.

Kadič, E. (2013). Govorica telesa in osebna karizma. Zavod za napredne študije delta, Ljubljana.

Keenan, K. (1996). Kako motiviramo. Mladinska knjiga, Ljubljana.

Koch, M. A. (2019). Muskelaufbau für Berufstätige - Das Maximal System: Mit nur vier Stunden pro Monat nachhaltig zum Traumkörper. Amazon Distribution, independently published.

Kovač, J., Vila, A. (1997). Osnove organizacije in managementa. Moderna organizacija, Kranj.

Kralj, J. (2003). Management: temelji managementa, odločanje in ostale naloge managerjev. Visoka šola za management, Koper.

Kržišnik, R. (2005). Zdrav individualizem kot pogoj timskega dela: dobro sodelovanje temelji na spoštovanju individualnih razlik. HRM: strokovna revija za ravnanje z ljudmi pri delu, letnik 3 , št. 9, str.32-37.

Le Poole, S. (1995). Never take no for an answer: a guide to successful negotiation. Kogan Page, London.

Mihalič, R. (2008). Povečajmo zadovoljstvo in pripadnost zaposlenih: praktični nasveti, metodologija, interni akt in model usposabljanja, za upravljanje in merjenje zadovoljstva in pripadnost zaposlenih, z ukrepi za večje zadovoljstvo pri delu in pripadnost organizaciji. Mihalič in Partner, Škofja Loka.

Možina, S. (2002). Management - nova znanja za uspeh. Didakta, Radovljica.

Novak, A., Podbregar, I. (2019). Lojalnost zaposlenih je dosegljiva s podporo vodstva pri doseganju osebnih ciljev. Magistrsko delo, Fakulteta za organizacijske vede, Kranj.

Podbregar, I. (2006). Znanje, timsko delo, predanost poklicu. Defensor, Ljubljana.

Podbregar, I. (2019). Vodenje in upravljanje organizacij. Predavanje pri predmetu Sodobne teorije organizacije in managementa, Fakulteta za organizacijske vede, Kranj.

Rosenbaum, D. A. (2010). Human motor control. Elsevier, Amsterdam.

Smith, L. (2005). Effective internal communication. Kogan Page, London.

Stuart - Kotze, R. (2006). Performance: the secrets of successful behavior. Financial Times Prentice Hall, London.

Šprajc, P. (2005). Marketinški model vodenja in izvajanja izobraževalnih storitev v visokem šolstvu. Doktorska disertacija, Fakulteta za organizacijske vede, Kranj. 
Šprajc, P., Podbregar, I. (2018). Paradigma kompetenc v kadrovskem managementu. Znanstvena monografija, 1. Izdaja, str.113-135. Univerzitetna založba UM.

Šprajc, P., Podbregar, I. (2018). Perspektiva obvladovanja tveganj na področju kadrovskega managementa. Članek, poglavje v monografiji, str. 137-153. Univerzitetna založba UM.

Trček, J. (1994). Medosebno komuniciranje in kontaktna kultura. Didakta, Radovljica.

Vila, A. (1994). Organizacija in organiziranje. Moderna organizacija, Kranj.

\section{Spletni viri}

https://www.zdravstvena.info/vsznj/proces-zdravstvene-nege/

https://sabinehindrichs.vpweb.de/dokumentation-strukturmodell

https://www.gallup.com/press/178343/gallup-press.aspx

http://www.kadrovsko-

svetovanje.si/celovita_kadrovska_ponudba/4/svetovanje_pri_zaposlovanju.html www.officevibe.com 


\title{
VODENJE MILENIJCEV IN
}

\section{MEDGENERACIJSKO USKLAJEVANJE V ORGANIZACIJAH}

\author{
EVA JEREB \\ Univerza v Mariboru, Fakulteta za organizacijske vede, Kranj, Slovenija. \\ E-pošta: eva.jereb@um.si
}

Povzetek V prihodnosti lahko pričakujemo velike spremembe na področju strukture delovnih mest. Tehnološki napredki in digitalizacija bodo zahtevali višjo stopnjo sodelovanja in bolj fleksibilno delovno okolje. Svoje bo terjala tudi avtomatizacija, ki bo prinesla ogromne spremembe, primerljive s spremembami industrijske revolucije. Poleg tega na delovna mesta prihaja generacija $\mathrm{Y}$, katere pripadnike imenujemo tudi milenijci, ki se močno razlikuje od prejšnjih generacij, še posebej od generacije, ki ji pravimo babyboomerji in ki trenutno še vedno zaseda določena ključna delovna mesta. Milenijci na delo in delodajalca gledajo drugače kot prejšnje generacije in imajo tudi drugačna pričakovanja. Če se organizacije v času tako velikih sprememb managementa ne bodo prilagodile novi delovni sili in ne bodo znale uskladiti zaposlenih različnih generacij, se bodo srečale z velikim mankom zaposlenih, sploh na ključnih delovnih mestih. $\mathrm{V}$ prispevku je najprej podanih nekaj osnovnih značilnosti trenutno najbolj zastopanih generacij na delovnih mestih $\mathrm{v}$ organizacijah. To so tako imenovani babyboomerji, generacija X in milenijci. Ne bomo pa govorili o veteranih in prihajajoči generaciji Z. Nadalje so predstavljene osnove vodenja trenutno najobsežnejše generacije delovne sile, to je milenijcev. Podani so predlogi, kako ravnati $\mathrm{z}$ novo, mlado delovno silo in kako usklajevati predstavnike različnih generacij, da bodo le-ti zavzeti za delo.

Ključne besede: generacije, milenijci, delovna sila, vodenje, medgeneracijsko usklajevanje. 


\title{
LEADING MILLENNIALS AND INTERGENERATIONAL COORDINATION IN ORgaNiZATIONS
}

\author{
EVA JEREB \\ University of Maribor, Faculty of Organizational Sciences, Kranj, Slovenia. \\ E-mail: evaj.jereb@um.si
}

\begin{abstract}
In the future, we can expect significant changes in the field of job structure. Technological advances and digitization will require a higher level of collaboration and a more flexible working environment. Automation will bring enormous changes comparable to those of the Industrial Revolution. Besides, generation $\mathrm{Y}$ also referred to as millennials, which is very different from previous generations, especially the generation we call baby boomers and currently occupy specific key jobs, is becoming a new workforce. Millennials view work and employer differently than previous generations and have different expectations. If organizations do not adapt their management to the new workforce and are not able to reconcile employees of different generations during such significant changes, they will face a large shortage of employees, especially in key jobs. In the paper, some essential characteristics of the currently most represented generations in workplaces are presented. These are the so-called baby boomers, generation $\mathrm{X}$, and millennials. Then the basics of managing the most comprehensive generation of the workforce, the millennials, are presented. Suggestions on how to deal with a new, young workforce and coordinate representatives of different generations to be engaged in work are given.
\end{abstract}

Keywords: generations, millennials, workforce, leadership, intergenerational coordination. 


\section{$1 \quad$ Generacije}

Danes se na delovnih mestih večinoma prepletajo predstavniki treh generacij, ki se med seboj precej razlikujejo. To so generacija babyboomerjev, katere predstavniki so rojeni med 1946 in 1964, generacija X, katere predstavniki so rojeni med 1965 in 1979, ter generacija Y oz. milenijci, katere predstavniki so rojeni med 1980 in 1999. Leta rojstev generacij se v literaturi sicer med seboj razlikujejo. Različni avtorji tako navajajo različne letnice rojstev posameznih generacij. V Centru generacijske kinetike (The Center for Generational Kinetics, 2016a) ugotavljajo, da je pojav različnih letnic generacij povezan $z$ geografsko lego; $v$ različnih delih sveta so namreč ob določenem času značilne različne značilnosti, trendi in veliki dogodki, ki dramatično vplivajo na generacijo. To sovpada s pojmovanjem generacije po Becton, Walker in Jones-Farmer (2014), ki navajajo, da se generacija nanaša na skupine posameznikov podobne starosti, ki so doživeli podobne zgodovinske, socialne in življenjske dogodke v določenem obdobju. Jorgensen (2003) na primer navaja, da sodijo med predstavnike generacije babyboomerjev tisti, ki so rojeni med 1946 in 1962, med predstavnike generacije X tisti, ki so rojeni med 1963 in 1978, ter med predstavnike generacije Y tisti, ki so rojeni med 1979 in 1988. Gravett in Throckmorton (2007) navajata, da sodijo med predstavnike generacije babyboomerjev tisti, ki so rojeni med 1946 in 1964, med predstavnike generacije X tisti, ki so rojeni med 1965 in 1976, ter med predstavnike generacije Y tisti, ki so rojeni med 1977 in 1990. Gursoy, Geng-Qing in Karadag (2013) navajajo zopet druge letnice rojstev posameznih generacij. Po njihovih navedbah $v$ generacijo babyboomerjev sodijo tisti, ki so rojeni med 1946 in 1964, med predstavnike generacije X tisti, ki so rojeni med 1965 in 1980, ter med predstavnike generacije $\mathrm{Y}$ tisti, ki so rojeni med 1981 in 2000 . V Centru za generacijsko kinetiko na podlagi številnih raziskav uporabljajo sledeča rojstna leta kot splošna začetna in končna leta za vsako od petih generacij (The Center for Generational Kinetics, 2016b):

\footnotetext{
- generacija z, rojeni 1996 do danes,

- generacija y ali milenijci, rojeni od 1977 do 1995,

- generacija x, rojeni od 1965 do 1976,

- babyboomerij, rojeni od 1946 do 1964,

- veterani, rojeni leta 1945 in prej.
} 
Kot vidimo, so raziskovalci in zgodovinarji uporabili različna imena in datume za opredelitev generacij, vendar se v osnovi strinjajo s splošnimi značilnostmi in vedenjem teh skupin (Lissitsa in Kol, 2016). Zavedati se moramo, da se predstavniki posamezne generacije sicer lahko rodijo tri leta prej ali kasneje, kot je mejnik posamezne generacije, in imajo vse značilnosti generacije pred ali po njej. To je povezano s številnimi dejavniki, vključno s starostjo staršev, okoljem odraščanja, npr. ali odraščajo $\mathrm{v}$ urbanem ali podeželskem okolju, finančno situacijo, izobraževanjem in drugimi dejavniki. $\mathrm{Na}$ primer: odraščanje $\mathrm{v}$ določenem geografskem področju lahko spremeni tudi generacijsko identiteto. Za Severno Ameriko na primer za generacijo Y oz. milenijce uporabljajo rojstna leta od 1977 do 1995. Ta se razlikujejo od nekaterih prej navedenih virov, ki navajajo, da je konec za milenijce celo leto 2000. V Centru generacijske kinetike verjamejo, da je leto rojstva 2000 napačno. Kot razlog navajajo najpomembnejši trenutek za milenijce (zlasti v ZDA) 11. september 2001. Izredno težko je namreč, če ne nemogoče, biti rojen med letoma 1996 in 2000 in imeti močno, čustveno povezavo z 11. septembrom. V tem obdobju so možgani preprosto premladi, da bi dogodek postavili v kulturni, geografski ali drug kontekst. Gre za nekaj, česar se rojeni med 1996 in 2000 preprosto ne morejo spomniti, in zato sodijo predstavniki tega obdobja $v$ generacijo Z. Za razumevanje in premostitev generacij tako uporabljamo različna leta kot izhodišče za eno ali drugo generacijo. Bolj pomembno kot osredotočenje na neko točno določeno leto rojstva je, da se osredotočimo na temeljno vedenjsko skladnost ali pomanjkanje le-te. Na primer: trenutna situacija velike brezposelnosti v Atenah v Grčiji danes milenijce privede do drugačnih pričakovanj in vedenja kot pa milenijce nekje drugje ob istem času, ko je trg dela $\mathrm{v}$ razcvetu. $\mathrm{V}$ večini primerov, razen pri dogodkih, ki opredeljujejo generacije, kot je npr. 11. september, je prehod iz ene generacije v drugo bolj postopen in mešan čez nekaj let.

\section{Babyboomerji - rojeni od 1946 do 1964}

Pripadniki skupine babyboomerjev trenutno še vedno prevladujejo na najvišjih položajih $\mathrm{v}$ večini organizacij in imajo tudi največji vpliv v zadnjih desetih letih. Ta trend pa se bo počasi zaključil, saj se jih bo večina $\mathrm{v}$ zadnjih letih upokojila. Babyboomerji so svoje vrednote oblikovali v času gospodarske rasti, ko je vse pomembnejša postajala izobrazba, ki je bila temelj razvoja družbe. Uvideli so, da je življenje kratko in ga je treba izživeti. Babyboomerji so v otroštvu dobili delovne navade od staršev. Postali so pohlepni po materialnih dobrinah (IZZA d. o. o.). Babyboomerji živijo za delo in večinoma povezujejo to, kar delajo, s tem, kar so. 
Delo je vedno predstavljalo sidro njihovega življenja in so ponosni na število ur, preživetih $\mathrm{v}$ pisarni. Lahko bi jih označili za deloholike, saj menijo, da bi moral vsakdo preživeti veliko časa na delovnem mestu, ker bi bil s tem produktiven in bi pokazal pripadnost (Phillips, 2019). Verjamejo, da sta trdo delo in žrtvovanje cena za uspeh (Patterson in Pegg, 2008). Babyboomerji so procesno naravnani in cenijo dobro definirane procese bolj kot doseganje rezultatov. Čeprav želijo biti produktivni, so bolj osredotočeni na sledenje določenim proceduram, po katerih bodo opravili svoje delo. Čas, preživet v pisarni, jim pomeni enako kot doseganje rezultatov. Seveda pa hočejo biti za dobro opravljeno delo tudi ustrezno finančno nagrajeni (Phillips, 2019). So tekmovalni in merijo uspeh $\mathrm{v}$ materialistični obliki (Becton, Walker, Jones-Farmer, 2014). Denar je za njih najboljši način nagrajevanja zaposlenih. Babyboomerji imajo spoštljiv odnos do vodstva. Medtem ko si določene osebe morajo zaslužiti spoštljiv odnos, so babyboomerji nagnjeni k spoštovanju vseh na vodstvenih položajih. Prav tako kot menijo, da so ure, preživete v pisarni, enako pomembne kot produktivnost, jih večina meni, da morajo čakati v vrsti, dokler njihovi predhodniki ne bodo odšli, potem pa bodo oni lahko prevzeli vodilne položaje. Zato v primeru, da so spregledani in jih nadomesti nekdo drug, ki po njihovem mnenju ni na vrsti, sploh pa če je mlajši od njih, hitro postanejo nejevoljni in pride do trenj (Phillips, 2019). So lojalni nadrejenim in sprejemajo hierarhično razmerje na delovnem mestu (Gursoy, Geng-Qing Chi, Karadag, 2013).

Sicer ne nasprotujejo delu v timu, vendar nimajo neke močne želje po sodelovanju z drugimi. Menijo, da morajo biti mlajši zaposleni poslušni in podrejeni starejšim, ki so v organizaciji dlje od njih. Velikokrat ne razumejo potrebe po »team buildingu« in drugih aktivnostih, kjer so lahko udeleženi vsi zaposleni. Informiranje za njih poteka strogo na ravni tistih, ki morajo biti vpleteni. Glede na to, da nimajo želje po druženju in sodelovanju ter da je njihova želja po inoviranju minimalna, informiranje in vključevanje drugih ni njihov primarni cilj. Ne nasprotujejo izmenjavi informacij z vpletenimi na skupnem projektu, ampak ostale zaposlene vključujejo le, če je to res nujno potrebno. Babyboomerji najraje komunicirajo osebno ali po telefonu. Manj so navdušeni nad korespondenco preko elektronske pošte, instant oziroma takojšnjih sporočil ipd. Tudi v primeru večjih razdalj gredo na sestanek raje osebno, kot pa da bi se poslužili sodobne tehnologije. Ne glede na to, da je osebna komunikacija včasih manj primerna, se je poslužujejo veliko raje kot vseh drugih oblik. To sovpada tudi z njihovim mnenjem, da bi morali biti ljudje $\mathrm{v}$ pisarnah na svojih delovnih mestih, da bi bili produktivni. Ker se dobro počutijo $\mathrm{v}$ trenutnem okolju in so potopljeni $\mathrm{v}$ svojo tradicijo, niso zainteresirani za inovacije. Inovacijo bodo podprli, če bodo 
videli prednost za podjetje, vendar ne razumejo, zakaj je potrebno neprestano modificirati operacije, razvijati nove procese ali vpeljevati nove tehnologije. Glede na slednje, tudi niso ravno navdušeni nad prednostmi, ki jih prinaša sodobna tehnologija. Ker niso zrasli v okolju, kjer bi od malega uporabljali in razumeli sodobno tehnologijo, je to za njih težko. Problem se z današnjo hitrostjo razvoja tehnologije samo še povečuje (Phillips, 2019). Nesposobnost hitremu prilagajanju novi tehnologiji nadomeščajo z dolgoletnimi izkušnjami (Appelbaum, Serena, Saphiro, 2005).

Babyboomerji so lojalni svoji organizaciji in so pripravljeni za korist organizacije žrtvovati svoje osebno življenje. Čeprav so odprti za nove priložnosti pri drugih organizacijah, se večina, sploh tisti, ki so v zaključnem kariernem obdobju, odloči, da raje dočaka upokojitev v trenutni organizaciji (Phillips, 2019). Poleg tega si želijo podaljšati življenjsko dobo, kar bo pripeljalo do nadaljnjih reform upokojevanja (IZZA d. o. o.).

Prepričani so, da ima obleka velik pomen, sploh na delovnem mestu. Tako kot njihovi starši tudi oni menijo, da je za določene aktivnosti, sploh pa v okviru službe, zelo pomemben profesionalni izgled, ki ga lahko zagotovijo z ustrezno obleko. Zato prihajajo na delovna mesta oblečeni formalno. Babyboomerji imajo zelo visoko delovno etiko in cenijo tradicijo. To so sicer dobri atributi, vendar lahko vodijo $\mathrm{v}$ rigidnost in nesposobnost prilagajanju spremembam (Phillips, 2019).

\section{Generacija X - rojeni od 1965 do 1979}

Pripadniki generacije X so doživeli padec berlinskega zidu, konec hladne vojne, razpad komunizma, konec apartheida $\mathrm{v}$ Južni Afriki in še kaj. Ta kulturna ozadja so močno definirala generacijo »work hard, play hard«, ki je zdaj na vrhuncu svoje kariere (Woo, 2018). Pripadniki generacije X sicer ne želijo biti deloholiki kot njihovi predhodniki, vendar so pripravljeni trdo delati. Pomembno jim je ohranjanje ravnotežja med delom in zasebnim življenjem, zato nenehno iščejo ravnovesje med družino, življenjem in delom (Tan, 2012). To jim omogoča vključevanje v številne aktivnosti izven službe. Nadurno delo in vlaganje ekstra truda jim ne predstavljata težav. Pripravljeni so storiti, karkoli je potrebno, da bo delo opravljeno. Niso pa zainteresirani preživljati nepotrebnega časa na delovnem mestu. Enostavno si želijo priti na delovno mesto, opraviti delo in oditi domov. Želijo si različnih formalnih načinov priznavanja dobro opravljenega dela, kot na primer: povišanje plače, 
napredovanje, vključitve $\mathrm{v}$ projekte, ki jim lahko prinesejo nove priložnosti idr. Cenijo pa tudi manj tradicionalne ugodnosti, kot na primer: prilagodljiv delovni čas in delo od doma. Pripadniki generacije X so se pripravljeni še posebej potruditi, da ustrežejo vodjam, ki jim zaupajo. Čeprav tradicionalno spoštujejo avtoriteto in svoje nadrejene, so se pripravljeni potruditi le za tiste vodje, ki držijo svojo besedo in obljubljeno tudi realizirajo ter vodijo z zgledom. Če vodje v tem niso uspešni, v očeh pripadnikov generacije X hitro izgubijo spoštovanje (Phillips, 2019).

Generacija X je postala polnoletna v dobi družin, ko sta bila zaposlena tako oče kot mati. Poleg tega je prihajalo do vse več ločitev, zato so morale mame opravljati več del in so bili prepuščeni sami sebi. Posledično je generacija X neodvisna, iznajdljiva in samozadostna (Kane, 2018a). Ker so bili večino časa prepuščeni sami sebi, se dobro počutijo, če delajo sami. Po drugi strani pa so veliko časa preživeli $\mathrm{v}$ popoldanskem varstvu s svojimi sovrstniki, tako jim ni problem delati in se dobro znajdejo tudi v timu.

Cenijo svobodo in odgovornost na delovnem mestu. Pripadniki generacije X verjamejo v koristnost transparentnosti pri delu. To velja še posebej, ko gre za informiranje. Verjamejo, da je v znanju moč in da več ko imajo informacij, bolje je to za njih in za organizacijo. Komunicirajo tako neposredno kot posredno s pomočjo sodobne tehnologije (elektronska pošta, instant sporočila idr.). Uporabijo medij, ki je v dani situaciji najprimernejši. Glede navdušenja nad inovacijami so nekje vmes med babyboomerji in milenijci ter sprejemajo spremembe in novosti $\mathrm{s}$ skepticizmom. K vsaki inovaciji pristopijo z določeno mero negotovosti in skrbno pretehtajo njene prednosti in slabosti. Pripravljeni so sprejeti smiselne izboljšave na delovnem mestu, ne pa nekaj samo zaradi spremembe same. Ker sta v tem času računalništvo in internet postala široko dostopna, je ta skupina rasla s hitrim razvojem tehnologije (Wiley, 2019). Čeprav se ne bojijo novih tehnologij in sprejemajo prednosti, ki jih le-te prinašajo, pa se ne privajajo ravno najhitreje. Preden investirajo v novo tehnologijo, si dodobra ogledajo, kako le-ta deluje.

Predstavniki generacije X so predani delu, ki ga opravljajo, ne pa tudi delodajalcu. Zato morajo delodajalci poskrbeti, da se počutijo vpletene in jim nuditi možnost razvoja. Za karierni napredek so pripravljeni delodajalca tudi zamenjati. Glede oblačenja so bolj sproščeni kot babyboomerji. Ne vidijo potrebe, da bi neprestano nosili formalna oblačila. Zdi pa se jim prav, da se napravijo formalno, kadar gre za pomembne sestanke ali srečanja s strankami. Za vsakodnevni delavnik se radi 
oblečejo v bolj sproščena oblačila. Pomembna jim je socialna odgovornost, filantropija in vlaganje v skupnost. So mnenja, da se vse obrestuje (Phillips, 2019). Čutijo potrebo po pripadnosti, pomembni so jim odnosi s sodelavci in si želijo zabave na delovnem mestu (Rani in Samuel, 2016).

\section{Generacija y oz. milenijci - rojeni od 1980 do 1999}

Milenijci delajo zato, da živijo, in niso pripravljeni preživeti slehernega trenutka na svojih delovnih mestih. Prosti čas jim je pomembnejši od dela (Twenge, Campbell, Hoffman, Lance, 2010), zato posvečajo veliko pozornosti usklajevanju poklicnega in zasebnega življenja (Ng in Gossett, 2013). Sicer so zainteresirani za karierno napredovanje, vendar na njihov način in pod njihovimi pogoji. To pa ne vključuje zadrževanja v pisarni oz. na delovnem mestu od zore do mraka. Zelo visoko cenijo socialno življenje in nikakor niso pripravljeni zaradi dela zamuditi česarkoli. Prepričani so, da sta doseganje rezultatov in produktivnost bolj pomembna kot pa zgolj prisotnost na delovnem mestu. Če so sposobni svoje delovne obveznosti opraviti hitreje od drugih, pričakujejo, da bodo zato lahko bolj zgodaj zaključili delovni dan. Ker so mnenja, da bi morali ocenjevati delovno uspešnost zaposlenih zgolj na osnovi njihove produktivnosti in doseženih rezultatov, ne pa po tem, kako, kdaj in kje so delo opravili, so prepričani, da bi moralo biti dovoljeno opravljanje dela kjerkoli in kadarkoli njim ustreza. Ni pomembno, ali se nahajajo v pisarni, doma ali v kavarni. Finančne nagrade jih ne motivirajo tako zelo, kot so njihove predhodnike. Čeprav so hvaležni denarne povišice, jim le-ta ne pomeni toliko kot nematerialne prednosti, kot na primer: več prostega časa, možnost dela od doma, možnost sodelovanja pri pomembnih projektih ipd. (Phillips, 2019).

Milenijci priznavajo avtoriteto, ko jim le-ta omogoča sodelovanje (Wiley, 2019). Želijo sodelovati z vodjami, ki cenijo povratne informacije vseh zaposlenih (Fries, 2018). Sicer cenijo kvalitetno vodenje, vendar so nekateri ravno dovolj brezobzirni, da mislijo, da bi morali biti oni glavni. Razlogov za to je več oz. so različni, mogoče tudi zaradi obvladovanja prednosti novih tehnologij, ki jih starejši vodje ne razumejo ravno najbolje. Nikakor ne sprejemajo avtoritete tistih, ki to od njih pričakujejo zgolj zato, ker so na višjih položajih. Uživajo $\mathrm{v}$ timskem delu in medsebojnem sodelovanju. Čeprav se zavedajo svojih sposobnosti in doprinosa organizaciji, so navdušeni nad delom $v$ skupinah oz. timih, kjer do izraza pridejo talenti in sposobnosti vseh. 
Navajeni so na ogromne količine informacij. Posedovanje le-teh se je razširilo celo tako daleč, da jih skrbi oz. se prav bojijo, da bodo kaj zamudili. Socialni mediji, pametni telefoni in neprestan virtualni stik z vsemi, s katerimi želijo komunicirati, so ustvarili globoko željo po tem, da so informirani o vsem, kar se dogaja. To se je iz osebnega življenja preselilo tudi na poslovno (Phillips, 2019). Milenijci imajo najraje besedilna sporočila in takojšnja oz. instant sporočila, ker raje hitro natipkajo, kot pa da gredo skozi vse formalnosti, povezane z opravljanjem telefonskega pogovora. Velikokrat opravljajo več pogovorov hkrati, kar jim omogoča uporaba več oken hkrati za takojšnje sporočanje (Wiley, 2019). To jim omogoča komunikacijo s komerkoli, kadarkoli želijo. $\mathrm{V}$ določenih situacijah imajo še vedno raje osebno interakcijo, predvsem $\mathrm{v}$ kriznih situacijah si želijo neposredne komunikacije z vodstvom.

Cenijo inovacije in možnost optimizacije delovnih operacij. Želijo si neprestanega izboljševanja in inoviranja, ker mislijo, da je to edin način, kako ostati na vrhu. Imajo ekstremno željo po optimizaciji, spreminjanju in izboljševanju procesov. Če tega ni, vidijo to za posel kot korak nazaj. Za njih je glavna tehnologija in so se pripravljeni neprestano učiti, da bi znali uporabljati nove programe in tako povečali svoje sposobnosti. Ponosni so na to, da obvladajo nove tehnologije, in cenijo fleksibilnost, ki jim jo ta prinaša pri opravljanju dela. Pri tem pa pozabijo na stroške, ki so povezani z neprestanim posodabljanjem tehnologije. Ne zanima jih, kolikšno je breme, ki ga morajo prenašati organizacije, da si lahko privoščijo nova orodja, programe ali aplikacije (Phillips, 2019).

Za milenijce je rečeno, da bodo zamenjali veliko več delovnih mest in delodajalcev kot pripadniki prejšnjih generacij (Lyons, Schweitzer, Ng, 2015). Iščejo smiselno in privlačno delo ( $\mathrm{Ng}$ in Johnson, 2015). Pripravljeni so zamenjati organizacijo v trenutku, ko se jim nekje drugje ponudi boljša priložnost. Organizacije bodo morale zagotoviti delo, polno izzivov in novih priložnosti, če bodo želele zadržati milenijce. Pri svojem delu zahtevajo jasne usmeritve in takojšnjo povratno informacijo o uspehu (Daud, 2015). Pri izbiri delodajalca so pozorni tudi na možnost usposabljanja in razvoja, ki jo le-ta nudi, kot tudi na možnost hitrega napredovanja in opredeljeno poklicno pot (Hays, 2013). Radi delajo v sproščenem delovnem okolju, kjer so lahko oblečeni, kakor želijo. Ne marajo formalnih poslovnih oblek, tesnih suknjičev in kravat. To je tudi eden izmed razlogov, zakaj raje delajo od doma. Poleg fleksibilnosti delovnega časa in lokacije opravljanja dela so za milenijce zelo pomembni tudi dejavniki, kot so: pozitivna organizacijska kultura, priložnosti za nenehen razvoj, 
programi za izboljšanje počutja, etično obnašanje (Deloitte, 2017) ter prijazno, socialno naravnano delovno okolje, kjer bi moral šteti glas slehernega zaposlenega (Phillips, 2019).

Za lažjo preglednost so zgoraj opisane značilnosti vseh treh generacij predstavljene $\mathrm{v}$ tabeli 1.

Tabela1: Značilnosti generacij

(prirejeno po AMWA, 2012 in Phillips, 2019)

\begin{tabular}{|c|c|c|c|}
\hline & Babyboomerji & Generacija X & Milenijci \\
\hline Obdobje & $\begin{array}{l}\text { Duhovno } \\
\text { prebujenje. } \\
\text { Spolna revolucija. } \\
\text { Osvobodilno gibanje } \\
\text { žensk. }\end{array}$ & $\begin{array}{l}\text { Naftna kriza. } \\
\text { Gospodarska } \\
\text { negotovost. } \\
\text { Visoka stopnja } \\
\text { ločitev. }\end{array}$ & $\begin{array}{l}\text { Hitra komunikacija. } \\
\text { Družbeno izobilje. } \\
\text { Okrilje staršev. } \\
\text { Visoka raznolikost. }\end{array}$ \\
\hline $\begin{array}{l}\text { Osebnostne } \\
\text { značilnosti } \\
\text { generacij }\end{array}$ & $\begin{array}{l}\text { Tekmovalnost. } \\
\text { Pogajanja. } \\
\text { Pripravljenost iti »še } \\
\text { kilometer dlje«. }\end{array}$ & $\begin{array}{l}\text { Zanesejo se nase. } \\
\text { Skeptični. } \\
\text { Prevzemajo } \\
\text { tveganja. } \\
\text { Iščejo ravnotežje } \\
\text { med delom in } \\
\text { družino. }\end{array}$ & $\begin{array}{l}\text { Realni glede } \\
\text { sedanjosti. } \\
\text { Optimistični glede } \\
\text { prihodnosti. } \\
\text { Sodelovanje v } \\
\text { skupinah. } \\
\text { Moč, trdnost. }\end{array}$ \\
\hline Glavne vrednote & $\begin{array}{l}\text { Optimizem. } \\
\text { Osebna rast. } \\
\text { Osebno } \\
\text { zadovoljstvo. } \\
\text { Timski igralec. } \\
\text { Zdravje in dobro } \\
\text { počutje. } \\
\text { Delo. }\end{array}$ & $\begin{array}{l}\text { Izzivanje sistema. } \\
\text { Zabava in } \\
\text { neformalnost. } \\
\text { Pragmatizem. } \\
\text { Globalno } \\
\text { razmišljanje. } \\
\text { Usmerjenost k } \\
\text { rezultatom. }\end{array}$ & $\begin{array}{l}\text { Družbena zavest. } \\
\text { Moralnost. } \\
\text { Usmerjenost k } \\
\text { dosežkom. } \\
\text { Spoštovanje } \\
\text { raznolikosti. } \\
\text { Denar. }\end{array}$ \\
\hline Pogled na delo & Živijo, da delajo. & $\begin{array}{l}\text { Iščejo ravnovesje } \\
\text { med poklicnim in } \\
\text { zasebnim } \\
\text { življenjem. }\end{array}$ & Delajo, da živijo. \\
\hline Delovno mesto & $\begin{array}{l}\text { Procesna } \\
\text { usmerjenost. } \\
\text { Čas, preživet v } \\
\text { pisarni, je enako } \\
\text { pomemben kot } \\
\text { produktivnost. }\end{array}$ & $\begin{array}{l}\text { Usmerjenost v } \\
\text { rezultate. } \\
\text { Pridejo na delo, ga } \\
\text { opravijo in gredo } \\
\text { domov. }\end{array}$ & $\begin{array}{l}\text { Štejejo le } \\
\text { produktivnost in } \\
\text { rezultati. } \\
\text { Kje in kdaj opravijo } \\
\text { delo, ni pomembno. }\end{array}$ \\
\hline Nagrajevanje & $\begin{array}{l}\text { Denar. } \\
\text { Priznanje. } \\
\text { Ugled. }\end{array}$ & $\begin{array}{l}\text { Denar. } \\
\text { Svoboda. }\end{array}$ & $\begin{array}{l}\text { Smiselno delo. } \\
\text { Prosti čas. } \\
\text { Delo od doma. }\end{array}$ \\
\hline
\end{tabular}




\begin{tabular}{|c|c|c|c|}
\hline & Babyboomerji & Generacija X & Milenijci \\
\hline Vodstvo & $\begin{array}{l}\text { Spoštujejo } \\
\text { nadrejene. } \\
\text { Čakajo, da pridejo } \\
\text { oni na vrsto. }\end{array}$ & $\begin{array}{l}\text { Spoštujejo vodje, } \\
\text { ki vodijo z } \\
\text { zgledom. }\end{array}$ & $\begin{array}{l}\text { Spoštujejo vodje, od } \\
\text { katerih hitro dobijo } \\
\text { povratne } \\
\text { informacije. }\end{array}$ \\
\hline Timsko delo & $\begin{array}{l}\text { Raje delajo sami, } \\
\text { neodvisno. } \\
\text { Ne vidijo prednosti } \\
\text { tima. }\end{array}$ & $\begin{array}{l}\text { Se znajdejo v timu } \\
\text { ali individualno. }\end{array}$ & $\begin{array}{l}\text { Najraje delajo v } \\
\text { timih. }\end{array}$ \\
\hline Informiranje & $\begin{array}{l}\text { Delijo informacije le, } \\
\text { če je nujno } \\
\text { potrebno. }\end{array}$ & $\begin{array}{l}\text { V znanju je moč, } \\
\text { vidijo prednosti v } \\
\text { dobrem } \\
\text { informiranju. }\end{array}$ & $\begin{array}{l}\text { Strah, da ne bodo } \\
\text { česa zamudili. }\end{array}$ \\
\hline Komunikacija & $\begin{array}{l}\text { Osebna. } \\
\text { Telefon. }\end{array}$ & $\begin{array}{l}\text { Katerikoli način je } \\
\text { najbolj primeren. }\end{array}$ & $\begin{array}{l}\text { Sporočila. } \\
\text { Instant/takojšnja } \\
\text { sporočila. }\end{array}$ \\
\hline Tehnologija & $\begin{array}{l}\text { Počasi se prilagajajo } \\
\text { novi tehnologiji. }\end{array}$ & $\begin{array}{l}\text { So skeptični, a } \\
\text { bodo poskusili. }\end{array}$ & $\begin{array}{l}\text { Takoj sprejemajo } \\
\text { novosti. }\end{array}$ \\
\hline Inovacije & $\begin{array}{l}\text { Se upirajo } \\
\text { inovacijam in } \\
\text { spremembam. }\end{array}$ & $\begin{array}{l}\text { So skeptični, a } \\
\text { bodo sprejeli, če } \\
\text { vidijo dodano } \\
\text { vrednost. }\end{array}$ & $\begin{array}{l}\text { Spremembe so } \\
\text { nujne. } \\
\text { Stran s starim, da bo } \\
\text { prostor za novo. }\end{array}$ \\
\hline $\begin{array}{l}\text { Pripadnost } \\
\text { organizaciji }\end{array}$ & $\begin{array}{l}\text { Velika pripadnost. } \\
\text { Lojalni organizaciji } \\
\text { in sodelavcem. }\end{array}$ & $\begin{array}{l}\text { Srednja } \\
\text { pripadnost. } \\
\text { Lahko menjajo } \\
\text { delo in } \\
\text { organizacijo. } \\
\end{array}$ & $\begin{array}{l}\text { Minimalna } \\
\text { pripadnost. } \\
\text { Menjajo takoj, ko } \\
\text { dobijo boljšo } \\
\text { priložnost. }\end{array}$ \\
\hline Obleka & $\begin{array}{l}\text { Formalna poslovna } \\
\text { obleka. }\end{array}$ & $\begin{array}{l}\text { Poslovna in } \\
\text { sproščena oblačila. }\end{array}$ & Sproščena oblačila. \\
\hline Drugo & $\begin{array}{l}\text { Cenijo tradicijo. } \\
\text { Delovna etika. } \\
\text { Predanost. } \\
\text { Neprilagodljivost. }\end{array}$ & $\begin{array}{l}\text { Socialna } \\
\text { odgovornost. } \\
\text { Raznolikost. } \\
\text { Neformalnost. } \\
\text { Zabava. }\end{array}$ & $\begin{array}{l}\text { Socialna omrežja. } \\
\text { Multitasking. } \\
\text { Socialna } \\
\text { odgovornost. } \\
\text { Upirajo se pravilom. }\end{array}$ \\
\hline
\end{tabular}

\section{$2 \quad$ Vodenje milenijcev}

Prvič v zgodovini sodobne delovne sile delajo skupaj zaposleni iz toliko različnih generacij. Nekateri sodelavci določenih posameznikov so tako mladi kot njihovi otroci, drugi pa tako stari kot njihovi starši (Zemke, Raines, Filipczak, 2000). Vodstvo se zaveda, da je danes na delovnem mestu starost enako pomembna kot pričakovanja zaposlenih, njihovi učni stili, kultura, spol in druge značilnosti (Gursoy, Maier, Chi, 2008). 
Danes se bolj kot kadarkoli $\mathrm{v}$ preteklosti od vodij zahteva transparentno in odgovorno vodenje. Način vodenja se spreminja, in sicer od vodenja preko kontrole in ukazovanja k vodenju »s soglasjem«. Glas zaposlenih še nikoli ni imel toliko moči, kot jo ima danes preko socialnih medijev, odprte komunikacije in številnih javnih raziskav. Vodje bodo morali uvideti, da je to, kako jih zaznajo njihovi podrejeni, enako pomembno kot to, kako jih zaznajo njihovi šefi. Avtoriteta zaradi vodstvene pozicije danes zgublja na moči. Vodje morajo skrbeti za svoje podrejene, ker tako kot jih lahko odpusti njihov šef, tako so lahko zavrnjeni s strani podrejenih (Elliott in Corey, 2018).

Trenutno večino vodstvenih položajev zasedajo predstavniki generacije $\mathrm{X}$, ponekod pa še vedno babyboomerji. Na podrejene položaje pa prihaja vedno več milenijcev. Le-teh je samo v ZDA več kot 83 milijonov in so najhitreje rastoča kot tudi najbolj raznolika generacija delovne sile in potrošnikov (The Center for Generational Kinetics, 2016c). Milenijci imajo drugačen pogled na svet in delujejo na čisto drugačen način kot njihovi predhodniki. Kar je seveda razumljivo glede na definicijo generacije. Vsaka generacija je živela $\mathrm{v}$ času drugačnih socialnih in zgodovinskih dogodkov, ki so pripomogli k oblikovanju njihovih edinstvenih perspektiv, različnih ambicij in specifičnih pogledov na svet. Tako je pričakovano, da bo vsaka generacija pristopila $\mathrm{k}$ delu in življenju na način, ki ni vedno v kontekstu $\mathrm{z}$ drugimi skupinami zaposlenih. Danes se vodje, namesto da bi se prepustili sodobnemu pristopu vodenja in modificirali tehnike vodenja tako, da bodo zadovoljili potrebe zaposlenih, še vedno oprijemajo zastarelih in preživetih pristopov. To pa se bo moralo spremeniti, če bodo želele biti organizacije uspešne. Management se bo moral spoznati z bistvom vsake generacije, katere predstavniki so zaposleni v organizaciji, če bodo želeli biti uspešni pri njihovem vodenju. Zastarele, tradicionalne pristope, ki so sicer dobro delovali do sedaj, pa bodo morali opustiti. Perspektiva milenijcev je drugačna in $\mathrm{v}$ konfliktu s perspektivo njihovih starejših kolegov. Vodje bodo tako morali opustiti splošen način vodenja in se prilagoditi potrebam nove generacije (Phillips, 2019). Čas je, da vodje prenehajo razpravljati o milenijcih kot o problemu. Namesto tega bi se morali vprašati, kako lahko vprašanja in izzivi najmlajših zaposlenih pomagajo pri rasti organizacije in spreminjanju na bolje. Najlaže je reči, da so mladi in niso dozoreli realnosti (Barsh, Brown, Kian, 2016). Postavljajo pa pomembno vprašanje: »Zakaj mora biti tako?« $\mathrm{V}$ procesu poslušanja bodo vodje kmalu sprevideli, da milenijci želijo - tako kot oni - le najbolje za organizacijo. 
Vodje ne morejo počivati na lovorikah preteklosti, ampak se morajo neprestano razvijati in iskati nove načine, kako uspešno voditi svoje zaposlene. Čeprav se vodje trudijo in dajejo vse od sebe, da bi zadovoljili zahteve različnih generacij zaposlenih, so včasih njihova ravnanja zastarela in vse drugo kot optimalna. Tradicionalni pristopi $\mathrm{k}$ managementu postajajo danes neučinkoviti. Ti pristopi postavljajo zaposlenim omejitve, kako lahko opravljajo svoje delo. S tem pa jih omejujejo in preprečujejo, da bi odkrili nove, boljše načine dela. Prav tako s takim načinom vodenja ni mogoče dvigniti stopnje zavzetosti za delo, kaj šele interesa po izvrstnosti. Za milenijce je tak način vodenja utrudljiv in ga sovražijo. Ni skladen z njihovimi potrebami, ne ustvarja navdušenja in nikakor ne spodbuja njihove predanosti.

Milenijci si želijo agilnega vodenja. Tako vodenje omogoča učinkovito ravnanje v zapletenih, hitro se spreminjajočih pogojih in daje izredne rezultate. Usmerjeno je na usklajevanje številnih prioritet in odgovornosti, pri tem pa je odprto do načinov delovanja. Agilni vodje spodbujajo svoje podrejene k uporabi lastnih talentov pri odkrivanju inovativnih rešitev, spodbujajo analizo problemov z različnih zornih kotov in opogumljajo zaposlene, da pokažejo svojo intelektualno radovednost (Phillips, 2019).

\section{Odprta in odkrita komunikacija}

Pomanjkanje zaupanja je eden ključnih elementov, zaradi katerega postanejo zaposleni nezavzeti za delo (Elliott in Corey, 2018). Do nezaupanja prihaja, ker zaposleni na delovnem mestu ne povedo vsega in skrivajo, prikrivajo ali celo izkrivljajo določene stvari. Velikokrat pride celo do laganja. Ker se to dogaja že toliko časa, je postalo na delovnem mestu skorajda neopazno oz. se posamezniki sploh ne zavedajo tega početja. Prikrivanje resnice, pripovedovanje polresnic, zadrževanje informacij in nezadostno komuniciranje uničujejo zaupanje zaposlenih $\mathrm{v}$ organizacijo. Zaradi tega se ustvari organizacijska kultura »mi in oni«, ki deluje v nasprotju z zavzetostjo zaposlenih. Mlajše generacije zaposlenih oz. milenijci so na to še posebej občutljivi.

Elliott in Corey (2018) navajata, da je izjemno veliko vodij zaskrbljenih, da jim podrejeni prikrivajo določene stvari ali ne povedo resnice. Zelo malo je takih, ki se resnično potrudijo, da bi to preprečili in omogočili odprto in odkrito komuniciranje. Raje čakajo in mislijo, da se bo to s časom že vneslo, a se ne. Potrebno je ogromno 
truda, da se vzpostavi ustrezno vzdušje, kjer bodo vsi lahko svobodno povedali, kako stvari dejansko stojijo in kaj si o tem mislijo.

Problem je v hierarhiji. Moč je na vrhu, informacije pa na dnu. To je v svoji raziskavi »Ledena gora ignorance« leta 1989 odkril že Sidney Yoshida. Yoshida navaja, da so vrhu managementa poznani le $4 \%$ problemov, srednji management pozna $9 \%$ težav, vodje $74 \%$ težav, delavci na dnu hierarhične lestvice pa poznajo težave $\mathrm{v}$ $100 \%$ (Peatman, 2018) (slika 1).

Takega načina zadrževanja informacij in s tem prikrivanja problemov milenijci niso vajeni in ga ne marajo. So trenutno najbolj informirana generacija in jim je zadrževanje informacij tuje. Vse morajo vedeti in jih je celo strah, da bodo kaj zamudili.

Veliko organizacij je sicer že spoznalo, da si zaposleni, sploh milenijci, želijo komunikacije z najvišjim vodstvom (Barsh, Brown, Kian, 2016). Sedaj je potrebno pomagati še najvišjemu vodstvu razumeti, kje se nahajajo pomembne informacije in kako pomembna je obojesmerna komunikacija.

Glede na različne generacije zaposlenih se v organizacijah pojavljajo različne metode komuniciranja. Milenijci so bili že zelo zgodaj izpostavljeni tehnologiji in se nanjo zanašajo tako takrat, ko gre za zabavo, kot takrat, ko gre za interakcijo z drugimi (Bolton in ostali, 2013). Pri komuniciranju tako dajejo prednost pisanju sporočil in takojšnjih sporočil pred osebnim ali telefonskim razgovorom. Kljub možnosti uporabe takojšnjih besedilnih sporočil in drugih aplikacij za pisanje sporočil pa ostaja med milenijci še vedno priljubljena e-pošta (Alton, 2017). Poleg uporabe sodobne tehnologije si želijo hitre in takojšnje komunikacije in povratnih informacij. 


\section{Ledena gora ignorance}

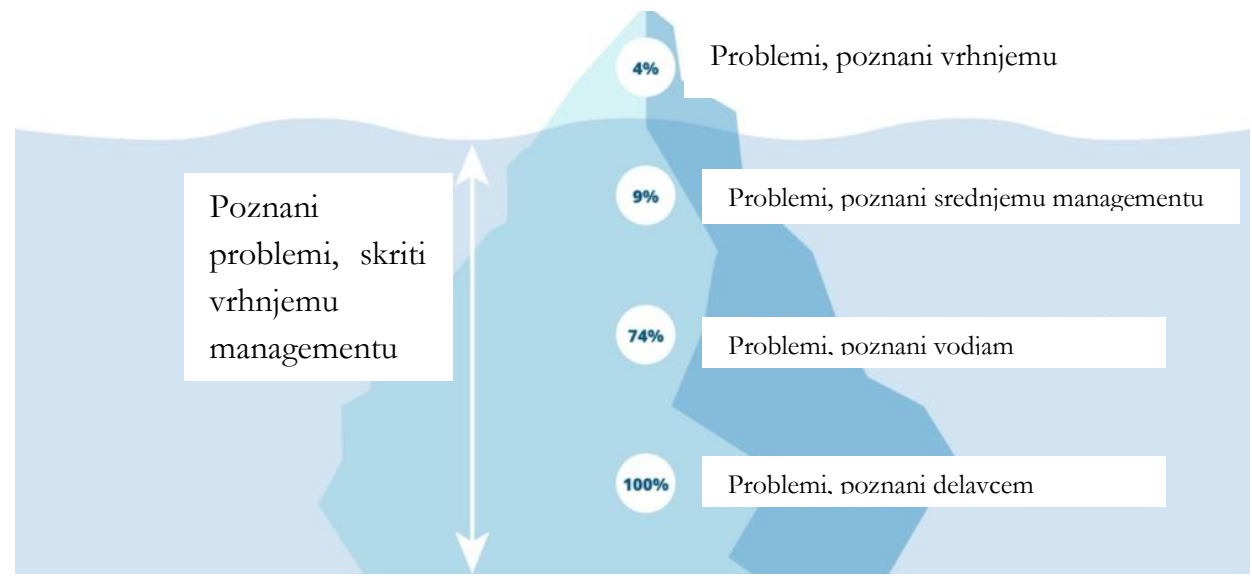

Slika 1: Ledena gora ignorance

(Elliott in Corey, 2018)

Če si želimo odprte in odkrite komunikacije, ki bo prinesla zaupanje in zavzetost mladih zaposlenih oz. milenijcev, moramo najprej zagotoviti neprestano povratno informacijo. Razgovor enkrat letno ni dovolj. Danes so redni letni razgovori sicer sestavni del skoraj vsake organizacije, vendar za milenijce to ni dovolj in potrebujejo bolj pogoste povratne informacije. Želijo vedeti, kaj delajo dobro, kje se lahko še izboljšajo in kako lahko neprestano rastejo. Milenijci si želijo vsaj tedenske, če že ne dnevne povratne informacije. Poleg tega si želijo, da smo do njih direktni. Komunikacija mora biti jedrnata, zgoščena in mora vsebovati pomembne informacije. Navajeni so na kratka sporočila in jih izgubimo takoj, ko jim posredujemo deset ali več strani dolga poročila o tem, kaj dobro delajo in kje se lahko izboljšajo. Zato moramo biti kratki in jedrnati. Enako velja v primeru osebnega razgovora, preiti želijo takoj na bistvo, vse ostalo se jim zdi izguba časa. Najraje vidijo, da jim stvari podamo na primeru in jim pokažemo, kako je njihovo ravnanje pozitivno ali negativno vplivalo na rezultat $\mathrm{v}$ določeni situaciji. Pri tem moramo biti pripravljeni na diskusijo, ker se ne bodo zadovoljili z našim monologom. Njihovi predhodniki so bili zadovoljni z enosmerno povratno informacijo, $v$ smislu nadrejeni bo že vedel. Za milenijce pa to ni več dovolj. Sicer še vedno spoštujejo svoje nadrejene in njihovo vodenje, vendar slepega zaupanja $\mathrm{v}$ to, kar oni rečejo, nimajo. 
Želijo si diskusije in konstruktivne kritike, da bodo razumeli, zakaj se je vodja tako odločil (Phillips, 2019).

Poleg tega se moramo zavedati, da so milenijci odraščali s tehnologijo $\mathrm{v}$ roki in da jim le-ta vse bolj zamegljuje črto med njihovim poklicnim in zasebnim življenjem. Milenijci ljubijo svoje telefone. Praktično jih imajo neprestano v rokah, kot bi bili sestavni del njih samih. So prva stvar, ki jo preverijo, ko se zjutraj zbudijo (Mustapha, 2019). Tej napravi posvečajo več pozornosti kot ljudem okoli sebe, bodisi v zasebnem ali poklicnem življenju. Vajeni so neprestanega komuniciranja preko telefona in drugih mobilnih naprav z uporabo aplikacij, kot so WhatsApp, Viber, Wechat, Facebook Chat idr. $56 \%$ pripadnikov te generacije bi premislilo, če bi se zaposlili pri delodajalcu, ki prepoveduje uporabo družbenih omrežij na delovnem mestu (Sungdoo, 2018; Wong, PennyWan, Hong Gao, 2017). Milenijci radi uporabljajo tehnologijo tudi za zasebne namene na delovnem mestu, pri čemer je veliko govora o zlorabi interneta (angl. cyberloafing) med delovnim časom (igranje iger, gledanje vsebin za odrasle, nakupovanje prek interneta ipd.). Nekatere organizacije prepovedujejo ali omejujejo uporabo interneta za zasebne namene, vendar raziskave kažejo, da to milenijce odvrača od takšnih delodajalcev in jih postavlja v dilemo. Treba je razumeti njihov avtonomni stil učenja, kjer v bolj kreativnih službah iščejo ideje $z$ branjem člankov in splošnim brskanjem po spletu (Sungdoo, 2018). Nekatere organizacije, predvsem v hotelirstvu, marketingu ipd., podpirajo uporabo družbenih omrežij za promocijske namene in delitev dogodkov podjetja na svojih profilih (Wong, PennyWan, Hong Gao, 2017). Tako morajo organizacije dobro premisliti, preden prepovedo uporabo interneta in uporabo številnih aplikacij za komuniciranje, ki jim milenijci pripisujejo izredni pomen.

In nenazadnje si milenijci želijo manj formalne komunikacije kot tudi samega delovnega okolja. Bolje delajo $\mathrm{v}$ sproščenem okolju, s prilagodljivim delovnim časom, sproščenim stilom oblačenja in neformalno, sproščeno komunikacijo. Želijo si prijazne komunikacije v prijaznem, umirjenem tonu. Pri tem moramo dodati, da radi uporabljajo tako imenovane emotikone (Alton, 2017). Če si vodje želijo uspešnega vodenja milenijcev, je navedeno smiselno upoštevati. 


\section{Kompenzacija za opravljeno delo}

Elliott in Corey (2018) menita, da se motimo, če še vedno mislimo, da je denar glavni element, s katerim bomo dosegli zavzetost zaposlenih. Njihova raziskava ni pokazala nobene korelacije med višino plače in zavzetostjo zaposlenih. Vodenje bi bilo relativno enostavno, če bi zavzetost zaposlenih za delo lahko motivirali z denarjem. Vendar s tem, ko nekomu damo več denarja, ne dosežemo pozitivnega, sploh pa ne dolgotrajnega vpliva na razumevanje smisla njegovega dela in doprinosa $\mathrm{k}$ uspehu organizacije kot celote. To seveda ne pomeni, da višina plače zaposlenim ni pomembna, vendar predstavlja le enega številnih dejavnikov, ki jih je smiselno upoštevati, če želimo imeti zavzete zaposlene.

Če pogledamo predstavnike prejšnje generacije, so bili ti zadovoljni že z majhno povišico plače, ne glede na to, da je bil učinek kratkotrajen. Milenijcem bi morali ponuditi enormno povišico, da bi pritegnili njihovo pozornost in zanimanje. Veliko več kot denar jim pomenijo druge stvari, kot na primer socialne pravice in osebno zadovoljstvo (ICONIXX, 2019). Poleg osnovnega, kot je na primer urejeno zdravstveno zavarovanje, si ta generacija želi številnih drugih ugodnosti, kot so možnost uporabe fitnesa, raznih oblik rekreacije. Na splošno jim je pomembna promocija aktivnega in zdravega načina življenja. Veseli bodo tudi plačanega kuharskega, padalskega tečaja ali tečaja risanja. Namesto denarne nagrade kot dodatka za izjemno dobro opravljeno delo jim omogočimo vnaprej plačane aktivnosti, bodisi za njih same ali še bolje za celoten tim (Phillips, 2019). S tem jim pokažemo, da nam veliko pomenijo, da jih cenimo in da se tudi mi trudimo za njih. Vse to vpliva na njihovo nadaljnjo zavzetost za delo in produktivnost.

Milenijcem več kot vsem prejšnjim generacijam pomeni prosti čas. Zato imajo radi natrpan urnik, da so popoldan prosti in se vključujejo $\mathrm{v}$ aktivnosti, $\mathrm{v}$ katerih resnično uživajo. Davis (2018) navaja, da je večina milenijcev na vprašanje, kaj jim je najbolj pomembno, odgovorila svoboda. Če so produktivni, v zameno pričakujejo fleksibilni delovni čas. Za njih je produktivnost veliko bolj pomembna, kot da sedijo v pisarni od jutra do večera. Opraviti nekaj ur dela zvečer ali čez vikend v zameno za proste ure med tednom, da lahko opravijo določene osebne zadeve, se jim zdi izrednega pomena. 
Druga možnost je, da jim omogočimo, da delajo na daljavo. Wright (2016) navaja, da veliko milenijcev med razgovorom za službo vpraša, ali bodo lahko delali na daljavo. Veliko jim namreč pomeni, če lahko delajo od doma. Kadar za opravljanje dela potrebujejo samo računalnik in internetno povezavo, se jim zdi nesmiselno, da sedijo na delovnem mestu v neki pisarni organizacije. Možnost dela od doma zelo cenijo, poleg tega jim zbudi občutek, da jim zaupamo.

Poleg navedenega jim je zelo pomembno prepoznavanje in priznavanje njihovega doprinosa oz. dobro opravljenega dela. Vodje bi jih morali pohvaliti za dobro opravljeno delo takoj, ko ga opravijo. Velikokrat se vodje sicer tega zavedajo, a ne storijo ničesar. Zaradi preobilice trenutnega dela pogosto prelagajo pohvalo na kasneje, s časom pa potem pozabijo ali pa si mislijo, da bodo počakali na pravi trenutek, ki pa nikoli ne pride. To seveda ni dobro, saj bodo zaposleni mislili, da vodje ne cenijo njihovega dela oziroma da ga sploh ne vidijo, kar bo zmanjšalo njihovo zavzetost za delo in posledično produktivnost. Če želimo, da bodo mlade generacije delale dobro, jim moramo pokazati, da jih priznavamo in cenimo njihov doprinos. Pri tem pa je izrednega pomena, da smo avtentični. Površno priznavanje in hvaljenje zaposlenih vsepovprek ni dobro. Pri tem moramo biti pozorni tudi na način izrekanja pohvale. Milenijci si po navadi, glede na to, da so neprestano prisotni na socialnih omrežjih, poleg zasebne pohvale s strani vodje želijo tudi javnega priznanja, na primer na spletnem socialnem omrežju LinkedIn. Poleg priznavanja posameznika pa milenijci veliko dajo tudi na priznavanje uspeha celotnega tima (Phillips, 2019).

\section{Tehnologija in inovacije}

Tehnologija in inovacije so danes ključnega pomena za uspešno poslovanje in rast. Pred 30 leti je bila tehnologija drugotnega pomena. Veliko več pozornosti je bilo posvečeno drugim aspektom poslovanja. Danes pa je tehnologija sestavni del skoraj vsake poslovne odločitve. Vsaka sprememba na področju tehnologije s seboj pripelje tudi spremembe na področju vedenja zaposlenih in njihovih odnosov. Novi programi in posodobitve poslovanja pomenijo tudi spremembe $\mathrm{v}$ načinu dela. Seveda pa to za zaposlene pomeni stres, ker se morajo neprestano prilagajati spremembam in modificirati svoje aktivnosti. Vse te novosti in spremembe sicer prinašajo dodane vrednosti, a vsi zaposleni niso nad njimi najbolj navdušeni (Phillips, 2019). Hitrost spreminjanja tehnologij in poslovnih operacij pa danes izziv še povečuje. V preteklosti so se te spremembe dogajale počasi, lahko bi celo rekli z 
ledeniškim tempom. Trajalo je več let ali celo desetletij, da je imela določena sprememba vpliv na celotno tržišče. Danes pa se ekonomija spreminja hitro in dinamično, kot bi bili trg, tehnologija in proizvodi v neprestanem toku. Vse se giblje hitreje kot kdaj koli do sedaj (Hoque, 2016). Čeprav bi se organizacije včasih najraje izognile neprestanemu spreminjanju in posodabljanju tehnologije ter uvajanju inovacij, pa je vse to nujno, ne le za ohranjanje posla in konkurenčnosti, ampak tudi zaradi zadržanja mlade delovne sile. Milenijci so namreč navdušeni nad sodobno tehnologijo in jim stalne spremembe ne povzročajo težav, temveč jim predstavljajo izziv. Organizacije, ki bodo hotele zadržati mlade kakovostne zaposlene, bodo tako morale nadgrajevati in posodabljati tehnologijo ter procese in uvajati novosti.

Za predhodnike milenijcev je bilo najpomembneje, da so bili postavljeni učinkoviti delovni procesi in predpisane procedure (Phillips, 2019). To je zaposlenim omogočalo, da so v relativno mirnem okolju in brez večjih presenečenj ter zapletov poskušali čim bolje dosegati postavljene cilje. Velikokrat tako ni bila v ospredju produktivnost, ampak samo potreba po izpeljani proceduri, ne glede na dosežene rezultate. To pa se je v zadnjih časih močno spremenilo. Danes določeni vodje še vedno cenijo dobro definirane procedure, ampak bodo morali, če bodo želeli ostati konkurenčni, to miselnost spremeniti. Osredotočiti se bodo morali na produktivnost in dovoliti mlajšim zaposlenim, da izkoristijo inovacije za postavljanje boljših procesov in poenostavljanje operacij. Danes je za napredek nujno potrebno, da se organizacije in management kot tudi vsi ostali zaposleni prilagajajo spremembam. Če bodo organizacije želele pridobiti in zadržati visoko produktivne oz. nadarjene zaposlene, bodo morale prilagoditi delovno kulturo naprednemu, tehnološko usmerjenemu pristopu, ki ga imajo tako milenijci kot tudi generacije, ki prihajajo za njimi. Upiranje spremembam bo samo povečalo fluktuacijo in ne bo poceni (West, 2018).

Večina milenijcev komaj čaka, da dobi v roke najnovejšo tehnologijo, ki je na trgu. Ne morejo se odreči najnovejšim aplikacijam in socialnim platformam in se z navdušenjem veselijo njihove uporabe. Včasih so nad tem tako navdušeni, da izgubijo občutek za vse ostalo okoli sebe, enostavno so omamljeni s svojo novo igračko (Phillips, 2019). Vendar v zadnjih letih sodobno tehnologijo prevzemajo tudi starejše generacije, zlasti predstavniki generacije X in tudi babyboomerji (Jiang, 2018). Analize raziskovalnega centra Pew Research Center (2018) so pokazale, da uporablja pametni telefon več kot devet od desetih milenijcev ( $92 \%$ ) v primerjavi s 
$85 \%$ predstavnikov generacije $\mathrm{X}$ in $67 \%$ babyboomerjev. Podobno velika večina milenijcev (85\%) pravi, da uporabljajo socialne medije (slika 2).

Pametni telefon

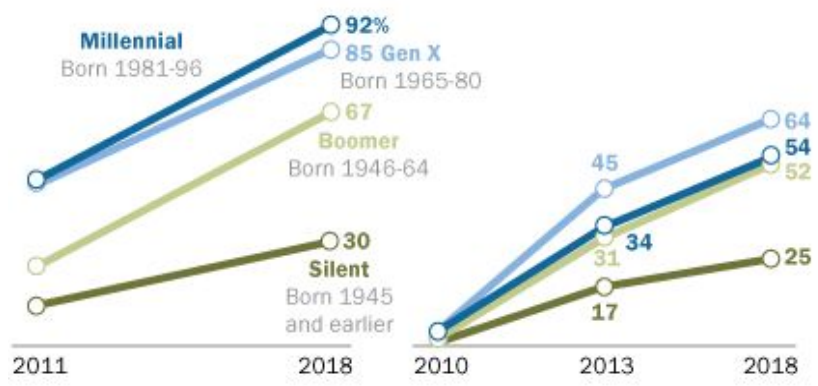

Prenosni računalnik

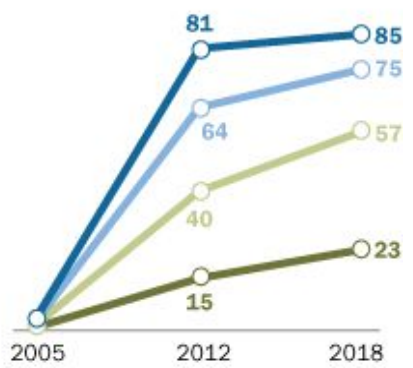

Slika 2: Odstotek pripadnikov različnih generacij, ki uporabljajo pametni telefon, prenosni računalnik in socialne medije

(Pew Research Center, 2018)

Problem, ki ga je sodobna tehnologija privedla s seboj, pa je uporaba le-te v zasebne namene med delovnim časom. Zaposleni med delom že čisto rutinsko preverjajo spletne strani, gledajo YouTube, opravljajo rezervacije potovanj itd. (Sungdoo, 2018). Zakrzewski (2016) navaja, da mlajši zaposleni danes dve od osmih ur na delovnem mestu posvetijo zasebnim zadevam. To naj bi ameriška podjetja letno stalo 85 bilijonov dolarjev zaradi zmanjšanja produktivnosti. Študija, ki jo je leta 2013 izvedel Ericson na vzorcu skoraj 2000 milenijcev, je pokazala , da jih večina opravlja zasebne zadeve med delovnim časom. Nemogoče jim je ločiti zasebno od poklicnega življenja, tako neprestano preverjajo Facebook in si izmenjujejo sporočila s prijatelji in družino (Ericson, 2013). Glede na zelo razširjeno uporabo tehnologije v zasebne namene med delovnim časom ni čudno, da se delodajalci bojijo zaposlovati milenijce oz. predstavnike mlajših generacij. Corgnet, Hernán-González in Mateo (2015) na primer navajajo primer za ZDA, kjer managerji številnih industrijskih podjetij raje zaposlujejo starejše delavce kot milenijce $\mathrm{z}$ enako mero izkušenj, ker mislijo, da so manj zanesljivi in manj pridni. Ne glede na to, ali je taka opredelitev milenijcev utemeljena ali ne, pa se je potrebno zavedati, da milenijci že danes predstavljajo večino delovne sile. Če torej organizacije želijo privabiti in zadržati milenijce, je ključnega pomena razumevanje njihovih značilnosti in zagotavljanje delovnega okolja, v katerem lahko delujejo in uspevajo (Stewart, Oliver, Cravens, Oishi, 2017). 
Glede na to, da milenijci neprestano posodabljajo tehnologijo, ki jo uporabljajo v zasebne namene, se težko sprijaznijo s tem, da jim to $\mathrm{v}$ organizacijah ni vedno omogočeno. Želijo si uporabe najsodobnejših naprav, aplikacij in storitev. Če želijo organizacije v prihodnosti uspešno obvladovati milenijce, jim morajo najprej omogočiti sodelovanje pri uvajanju novih tehnologij. Nadalje jim morajo dovoliti, da vsaj enkrat tedensko delajo od doma, kadar narava dela to omogoča. Za nekatere organizacije, še posebej sodobnejše, to ni problem, zopet za druge, ki imajo določena pravila in se držijo tradicije, to ni tako enostavno. Vendar zna togo oklepanje tradicije in starih navad kmalu predstavljati problem za milenijce in lahko povzroči veliko fluktuacijo. Ne glede na to, kako to vidijo predstavniki organizacij, bodo milenijci kmalu pričakovali, da bodo lahko delali od doma ali od kjerkoli drugje. Seveda za vsa dela to ne pride $\mathrm{v}$ poštev, kjer pa je to možno, je smiselno razmišljati $\mathrm{v}$ tej smeri. Milenijcem in generacijam, ki prihajajo za njimi, bomo morali omogočiti oz. dovoliti, da del dela, ki so ga dolžni opraviti za organizacijo, opravijo izven svojega delovnega mesta. Nadalje lahko milenijce uporabimo za poučevanje uporabe novih tehnologij predstavnikov starejših generacij. Tehnologija je super, če jo znamo uporabljati. Na žalost je danes $\mathrm{v}$ organizacijah še vedno veliko zaposlenih, ki novi tehnologiji niso kos ali pa se le s težavo privajajo na njeno uporabo. Če hočejo biti organizacije uspešne, morajo neprestano vpeljevati nove programe in posodabljati aplikacije. Tukaj lahko uspešno vključimo milenijce, sploh tiste, ki so še posebej navdušeni nad sodobno tehnologijo, da pomagajo ostalim zaposlenim pri učenju. Za milenijce sta vsak program in aplikacija življenjsko pomembni in menijo, da bo organizacija, če ne bo uporabila najnovejše in najboljše tehnologije, začela zaostajati za konkurenco, izgubila tržni delež in kmalu tudi posel. Namesto da rečemo ne in takoj zatremo njihove ideje o potrebni novi tehnologiji, jih zadolžimo, da pripravijo izčrpno poročilo o prednostih in slabostih, ki bi jo le-ta prinesla za organizacijo. $\mathrm{S}$ tem bodo spoznali, ali je dejansko potrebno uvesti novosti ali ne, obenem pa bodo razvijali managerske veščine, sploh če morajo pripraviti še stroškovno analizo, kjer bodo upravičili nabavo določene tehnologije. Milenijci namreč velikokrat ne vidijo stroškovnega vidika uvajanja nove tehnologije in inovacij (Phillips, 2019).

\section{Učenje in razvoj}

Milenijci si želijo, da bi se učili in rasli, podjetja pa bi morala biti na to pripravljena (West, 2018). 87\% milenijcev pravi, da so jim možnosti za poklicni razvoj ali možnosti za karierno rast zelo pomembne (Adkins, 2016). Pri tem pa bi lahko tradicionalne metode, kot so klasična predavanja, smatrali za zastarele, saj so odrasli 
z internetom, ki jim omogoča 24/7 dostop do vsega, kar želijo vedeti. S tehnološkimi rešitvami za e-učenje lahko podjetja izvajajo usposabljanje preko naprednih in stroškovno učinkovitejših kanalov, kot so sistemi za upravljanje učenja, podcasti in videi na zahtevo.

Ta mlada generacija je odraščala, gledajoč podjetnike, kako dosegajo vrhunec uspeha, še preden dopolnijo 30 let in pri tem prevzamejo odgovornosti, ki so običajno rezervirane za starejše vodstvene delavce, hkrati pa pridobivajo neizmerno bogastvo. Veliko mladih strokovnjakov si tako želi možnosti za razvoj svojih podjetniških sposobnosti. Za njih je vsako gibanje, ki spodbuja poklicni razvoj, plus (Barsh, Brown, Kian, 2016).

Umetna inteligenca je ena glavnih tehnologij, ki postavlja poslovanje v naslednjo dobo, znano pod imenom industrija 4.0. V skladu s poročilom o globalni raziskavi prihodnje delovne sile, ki jo je izvedel Dell \& Intel v letu 2016, 56 \% milenijcev meni, da umetna inteligenca vodi k večji produktivnosti na delovnem mestu (Wets, 2018). Avtomatizacija rutinskih in vsakodnevnih opravil daje zaposlenim več časa, da se osredotočijo na ustvarjalno delo, delo z dodano vrednostjo in na ljudi. Organizacije morajo pomagati svojim zaposlenim, da pridobijo spretnosti, ki so potrebne za izkoriščanje prednosti umetne inteligence. Raziskava podjetja Deloitt (2018), izvedena v letu 2018, je pokazala, da si milenijci želijo, da bi podjetja prevzela vodilno vlogo pri njihovi pripravi na industrijo 4.0., vendar jih je le $36 \%$ poročalo, da jim njihovi delodajalci pomagajo razumeti in se pripraviti na te spremembe. Sprejemanje in priprava na uporabo tehnologij industrije 4.0, kot je umetna inteligenca, bo močno vplivala na gibanje zaposlenih.

Milenijci želijo napredovati v svoji karieri. Prednost dajejo osebnemu interesu in konstruktivnim povratnim informacijam in ne marajo vodij, ki dodelijo naloge in pričakujejo rezultate brez interakcije (Zimmerman, 2016). Ostali bodo v organizaciji, kjer vlagajo $\mathrm{v}$ gradnjo odnosov in jim pomagajo, da se razvijajo in se tako počutijo cenjene (Bertino, 2017).

Organizacije bodo morale razviti kulturo mentorstva. Veliko mladih si želi sodelovanja in podpore sodelavcev, le malo podjetij pa je ugotovilo, kako zgraditi kulturo, ki pomaga obstoječim zaposlenim pri mentoriranju novincev (Barsh, Brown, Kian, 2016). Podjetje Sodexo je na primer uvedlo mentorstvo »kroga štirih ljudi«, kjer trije izkušeni zaposleni pomagajo pri vpeljavi novinca (Barsh, Brown, 
Kian, 2016). Podjetje Deloitte je na primer v svojo podjetniško kulturo uvedlo zanesljivo mentorstvo. Od mentorjev se pričakuje, da bodo dve leti namenili svojim varovancem in jih vodili skozi intenzivni učni program $z$ individualnim usposabljanjem za razvoj vodstvenih veščin (Deloitte, 2019). Ker pa se mladi na delovnem mestu razvijajo tudi potem, ko so že zaposleni, bodo organizacije poleg mentorstva novincem morale razmisliti o vpeljavi tudi drugih vrst mentorstev, kot na primer obratno mentorstvo, mikro mentorstvo in skupinsko mentorstvo.

Obratno mentorstvo se nanaša na pobudo, v kateri starejši vodstveni delavci sodelujejo z mlajšimi zaposlenimi, ki jih mentorirajo na področjih, kot so tehnologija, socialni mediji in trenutni trendi. $\mathrm{V}$ tehnološki industriji in tudi v drugih podjetjih, ki so močno odvisna od tehnologije, predstavlja obratno mentorstvo način, kako starejše zaposlene hitreje zbližati in vpeljati na področja, ki so mlajšim zaposlenim samoumevna, saj so njihova življenja že od samega začetka močno integrirana z računalniki in spletom (Techopedia, 2019). To predstavlja dvojno korist. Vodstvo je na tekočem s trendi, ki so izrednega pomena za organizacijo, mlajši zaposleni pa se počutijo bolj povezani in pomembni, ker prispevajo $\mathrm{k}$ izboljšanju svojega podjetja na najvišji ravni (Zimmerman, 2016). Zamisel, da bi višji vodstveni delavci lahko izvedeli nekaj od novih zaposlenih, je sicer $\mathrm{v}$ nasprotju s tradicionalnimi praksami na delovnem mestu, kjer so starejši, izkušeni zaposleni tisti, ki zagotavljajo največji vložek, sprejemajo odločitve in mentorirajo mlajše zaposlene $z$ manj izkušnjami. Vendar se bodo morali vodje sprijazniti, da je hiter razvoj tehnologije in trendov obrnil to logiko. Starejši zaposleni imajo sicer izkušnje in vpogled v poslovanje, primanjkuje pa jim veščin s področja novih tehnologij, katerih uporaba bo nujna za razvoj in ohranitev konkurenčnosti. Nekateri starejši vodstveni delavci so ob ideji, da jih bo mentoriral novozaposleni mlajši sodelavec, užaljeni. Drugi jih zopet vidijo kot priložnost za razvoj, kjer si novi in izkušeni zaposleni med seboj izmenjujejo znanje, spodbujajo razumevanje obeh skupin in izboljšujejo splošno komunikacijo in sodelovanje na delovnem mestu (Techopedia, 2019).

Mikro mentorstvo zajema manjše, bolj neformalne možnosti za mentorstvo. Socialni mediji ustvarjajo priložnosti za bolj pogosta mikro mentorstva, saj se lahko preko Twitterja ali LinkedIna povežemo z nekom, ki ima znanje ali izkušnje na določenem področju. Mikro mentorstvo je postalo priljubljeno zaradi možnosti številnih načinov povezav, ki so danes na dosegu roke, in tudi zaradi bolj neformalne in sproščene interakcije, ki je milenijcem bližja. S takim načinom ima nekdo lahko istočasno več mentorjev, saj se za različna delovna področja, kot so na primer 
pogajanje o plači, uvajanje, izvedba intervjuja, timsko delo, način dela z novim direktorjem itd., lahko obrne na različne vire (Zimmerman, 2016).

Skupinsko mentorstvo je namenjeno individualnemu razvoju, ki $\mathrm{v}$ skupinskem okolju združuje več strokovnjakov in učencev. Čeprav je učenje strukturirano kot skupina, je individualno in vsak učenec zadovoljuje svoje učne potrebe in razvojne cilje (Carvin, 2011). Prednost skupinskega mentorstva je v usklajevanju spretnosti. Mentorirani se lahko uskladi s tistimi mentorji, ki se odlikujejo na področju, ki ga želi izboljšati. Poleg tega si sam izbere, od koga se bo učil, na primer: mlada, novozaposlena mati si bo za mentorico raje izbrala starejšo izkušeno zaposleno mater, ki je šla skozi podobne življenjske dogodke. Prav tako si v okviru skupine zaposleni lahko iščejo mentorja, ki je enake starosti kot oni sami, a se bolje spozna na določeno področje, kot so tehnologija, socialni mediji, veščine v Excelu idr.

Obstaja več različnih razlogov, zakaj se lahko nekdo odloči za uporabo enega ali več različnih vrst mentorstva. Vsa imajo svoje prednosti in slabosti, ampak zavedanje, da ni treba imeti enotnega pristopa $\mathrm{k}$ mentorstvu, organizacijam omogoča razvoj in rast mladih strokovnjakov (Zimmerman, 2016).

\section{Kako ravnati}

Vsaka generacija ima določene navade, ki jo naredijo edinstveno, in pri milenijcih ni nič drugače. Zaradi teh raznolikosti je prepričanje, da jih lahko vodimo enako kot njihove predhodnike, napačno. Če želimo biti uspešni in zadržati mlade zaposlene, moramo prilagoditi vodenje. Če tega ne bomo naredili, obstaja velika verjetnost, da nas bodo zapustili. Pri tem je smiselno upoštevati naslednja vodila.

Ustvariti pozitivno kulturo organizacije. Delo je lahko stresno in veliko preveč podjetij oziroma organizacij ustvarja negativno delovno okolje z uporabo prisile, da bi dosegli določeno stopnjo produktivnosti. Čeprav nekateri menijo, da je dobro, da se zaposleni bojijo za svoja delovna mesta in da se ne razumejo ravno najbolje med seboj, je ravno stres pri delu odgovoren za nižjo produktivnost, več bolniških odsotnosti in večje stroške (Bertino, 2017). Še več, zaposleni, ki so neprestano pod visokim pritiskom, bodo verjetno slej ko prej zapustili organizacijo. Z ohranjanjem pozitivne kulture je večja verjetnost, da bodo zaposleni srečni. To pa se zazna tudi navzven in bo povečalo zanimanje bodočih kandidatov za zaposlitev $\mathrm{v}$ tej organizaciji. 
Priznavati dosežke posameznika in tima. Milenijci so usmerjeni $\mathrm{k}$ rezultatom. Pričakujejo priznanje za dobro opravljeno delo (Phillips, 2019). Pripravljeni bodo vložiti veliko truda, da bodo dosegli dobre rezultate. Na strani organizacije pa je, da to vidi in tudi ustrezno pohvali in nagradi. Milenijci so neodvisni in se zavedajo svojih sposobnosti, a kljub temu zelo radi delajo v timih. Radi delajo v sodelovalnem delovnem okolju, kjer se izrabljajo talenti vseh za dosego izjemnih rezultatov. $\mathrm{Na}$ koncu pa seveda pričakujejo, da bo organizacija to zaznala in jih tudi nagradila.

\section{Razložiti "zakaj«}

Večina milenijcev ima dostop do brskalnika Google že od srednje šole. Navajeni so, da lahko dobijo razlago, kaj stoji za vsem, kar vidijo in doživljajo. Delovno mesto pa ni kot Google, česar se milenijci ne zavedajo. Zato zasipavajo svoje vodje s številnimi vprašanji in pričakujejo utemeljitev ter razlago, kaj stoji za vsakim dejanjem (Millennial Boss, 2018). Vedeti hočejo, zakaj mora biti določena naloga opravljena, zakaj je treba obiskati določeno usposabljanje, zakaj je treba slediti določeni proceduri itd. Želijo si racionalne razlage za vsako sprejeto odločitev. Če hočemo, da bodo mladi zaposleni popolnoma predani svojemu delu, jim moramo podati jasne odgovore na njihova vprašanja in razložiti zakaj (Phillips, 2019). Potreba po poznavanju odgovora na vprašanje »zakaj« po eni strani pomeni, da so milenijci dobri zaposleni, po drugi pa je to lahko tudi zelo stresno za vodje.

\section{Zagotavljati povratne informacije in dostopnost vodstva}

Milenijci postanejo kar hitro razburjeni, če ne vedo, ali delajo pravilno oziroma tako, kot vodja od njih pričakuje. Zaradi tega želijo neprestane povratne informacije, da vedo, ali so na pravi poti. V primeru, da je vodja dostopen in je pripravljen dajati povratne informacije, se milenijci počutijo varne in se zavedajo, da je njihov vodja vedno prisoten in jim bo pomagal, če bo to potrebno. To seveda ne pomeni, da si želijo fizične prisotnosti vodje, pomembno je le, da je dostopen bodisi preko telefona (govor, takojšnja sporočila, sporočila) ali elektronske pošte (Phillips, 2019). 


\section{Skrbeti za karierni razvoj}

Milenijci želijo individualizirano osredotočenost in pozornost na svojo karierno pot, kjer se želijo čim hitreje povzpeti. Pričakujejo, da jim bodo vodje jasno povedali, kako hitro se lahko povzpnejo po lestvici ali kako hitro bodo dosegli želeni znesek plače. Poleg tega pa želijo vedeti, kako daleč so pri tem oziroma kje se nahajajo v vsakem trenutku in ne samo ob koncu leta oziroma v obdobju ocenjevanja delovne uspešnosti. Skope povratne informacije, kot je na primer "potrebujete več časa na tej stopnji, preden boste lahko napredovali« ali »kar nadaljujte z delom«, ne bodo dovolj. Poleg tega, da bi morali vodje svojim podrejenim dajati takojšnje in ustrezne povratne informacije, da le-ti točno vedo, kaj so naredili prav in kaj narobe, kar jim pomaga razumeti, kaj morajo storiti, da bodo napredovali, bi morali biti ravno vodje največji zagovorniki kariere svojih zaposlenih. Nenehno bi morali iskati priložnosti za svoje zaposlene, da izboljšajo svoje spretnosti, rastejo in poskušajo nove stvari. Mnogi delodajalci na primer omogočajo, da se zaposleni brezplačno udeležijo določenih tečajev in konferenc, vendar mnogi vodje ne spodbujajo svojih zaposlenih, da bi izkoristili to ugodnost. Vodstvo bi moralo svojim zaposlenim vsako leto dati čas, da razširijo svoje znanje. Poleg tega morajo vodje pomagati svojim mlajšim zaposlenim pri mreženju in napredovanju v podjetju. Nekateri vodje vsega tega ne počno, ker se bojijo, da bodo potem izgubili svoje najboljše zaposlene. $\mathrm{V}$ resnici bodo mlajši zaposleni odšli ravno zato, ker bodo mislili, da njihov vodja omejuje njihov razvojni potencial. Če pa bodo videli, da je njihov vodja njihov največji zagovornik, si bodo želeli delati pod njegovim okriljem. Milenijci potrebujejo priložnost, da se preizkusijo v različnih vlogah, saj kaj kmalu izgubijo interes, če morajo opravljati točno enako delovno funkcijo več let zapored (Millennial Boss, 2018). Zato moramo zagotoviti delovno okolje s priložnostmi za napredovanje in $z$ novimi izzivi (Heathfield, 2019).

\section{Vključevati tehnologijo}

$\mathrm{V}$ današnjem mobilnem in povezanem svetu je tehnologija tista, ki narekuje, kako komuniciramo, se družimo, in v mnogih primerih, kako se učimo in razvijamo (AuYong-Oliveira, Gonçalves, Martins, Brancob, 2018). Milenijci so kot prva generacija, ki se je rodila $\mathrm{v}$ digitalni dobi, zelo dobro tehnično podkovani in uporabljajo tehnologijo na drugačen način kot prejšnje generacije (Wavestone, 2018). Komaj čakajo, da lahko začnejo uporabljati tehnološko najnovejše in najboljše programe ali aplikacije. Zelo radi imajo novo tehnologijo in jo uporabljajo v vseh vidikih svojega 
življenja, vključno z delom. Zato moramo v čim večji meri vključiti tehnologijo v delovno okolje (Phillips, 2019). Na splošno se lahko milenijci - bolj kot predstavniki katere koli druge generacije - zelo hitro spoznajo z novo tehnologijo in jo obvladajo. Veliko hitreje usvojijo nova sodobna poslovna orodja kot nekateri starejši sodelavci, kar je velika prednost pri današnjem hitrem tempu s stalno spreminjajočo se tehnologijo (Wavestone, 2018).

\section{Omogočati, da preživijo čas z vodjo}

Na vrhu seznama stvari, ki si jih milenijci želijo na delovnem mestu, je preživeti več časa s svojim vodjo. Pri tem se moramo zavedati, da se milenijci, čeprav imajo določene skupne karakteristike, med seboj veliko bolj razlikujejo kot morda predstavniki prejšnjih generacij. Vodje so $\mathrm{v}$ preteklosti večino zaposlenih lahko vodili na enak način, danes pa to zaradi raznolikosti ne gre več. Potrebno se je potruditi in najti najprimernejši način vodenja za vsakega posameznika (Phillips, 2019). Milenijci težko prenašajo zastarelo politiko in standarde upravljanja delovne uspešnosti, zato pričakujejo, da se bodo vodje ustrezno prilagodili. Delo in življenje je za njih tesno prepleteno. Zaradi tega si tudi želijo drugačnega odnosa s svojim nadrejenim (Adkins, 2016). Močno si prizadevajo za interakcijo z vodstvom in želijo biti del razprave (Prevue, 2014). Želijo, da je vodja njihov zagovornik pri odpravljanju težav na delovnem mestu. Vodje pa so pogosto tako zaposleni, da si ne vzamejo časa, da bi svojim zaposlenim dali to, kar želijo in potrebujejo. Pomanjkanje neposrednega stika z vodjami pa zmanjšuje zvestobo mladih zaposlenih in lahko pripelje do tega, da začnejo iskati zaposlitev drugje. Osebni odnosi so ključnega pomena in organizacije, ki želijo zadržati svoje mlade zaposlene, se bodo morale tega še kako dobro zavedati (Barsh, Brown, Kian, 2016).

Nuditi izziv. Milenijce zanima delo, ki jim predstavlja izziv. Želijo si visoke vpetosti v poslovno okolje in sodelovati pri pomembnih poslovnih odločitvah. Želijo si delati pri velikih in pomembnih stvareh, a se jim velikokrat ne nudi te priložnosti. Namesto tega se jim zaupa le naloge, ki ne prinesejo velike dodatne vrednosti. Sicer je razumljivo, da se vodje bojijo in mislijo, da tako mladi še ne morejo biti kos zahtevnim nalogam, za katere so potrebne dolgoletne izkušnje, ampak njihova iznajdljivost, edinstvene sposobnosti in odločnost mnogokrat presenetijo. Če uvidijo, da sami ne bodo kos zahtevni nalogi, bodo poiskali pomoč in ne bodo odnehali (Phillips, 2019). Zato jim moramo dati možnost opravljanja pomembnih, 
zahtevnih oziroma težavnih nalog. To jih motivira, da se izpopolnjujejo, da rastejo, povečuje njihovo lojalnost in pripadnost ter nenazadnje dviguje produktivnost.

\section{Omogočati fleksibilnost}

Visoko prilagodljivo delovno okolje povečuje stopnjo lojalnosti zaposlenih (Deloitte, 2018). Predhodniki milenijcev so živeli za delo ali vsaj poskušali vzdrževati zdravo ravnovesje med poklicnim in zasebnim življenjem. Milenijci pa delajo zato, da živijo. Ne zanima jih, koliko ur preživijo na delovnem mestu, ampak kako čim bolj učinkovito opraviti svoje delo, da bodo imeli več časa za svoje priljubljene aktivnosti. Resnično si želijo maksimalno izživeti svoje življenje. Zato od njih ne moremo pričakovati, da bodo preživeli cel dan, od jutra do mraka, na svojem delovnem mestu v neki pisarni (Phillips, 2019). Omogočiti jim moramo mobilni dostop do dela, da lahko delajo kadarkoli od koderkoli.

\section{Poskrbeti za ustrezno socialno okolje}

Mnogi milenijci pripisujejo socialnemu okolju dela velik pomen. Številni mladi, ki so na začetku kariere, bolj kot družinski čas cenijo prijateljstvo in temu posvečajo veliko časa. Prav tako kot so jim pomembne dejavnosti, vezane na delo, so jim pomembne družbene dejavnosti, kjer lahko bolje spoznajo svoje sodelavce. Tako je smiselno razmisliti o organiziranju različnih dogodkov, kot na primer strokovne predstavitve za mlade strokovnjake, kjer se bodo lahko bolje spoznali med seboj. Razmisliti bi morali tudi o organizaciji družabnih in prostovoljnih dogodkov. Raziskati moramo, katere dejavnosti jih zanimajo. Spodbujati bi morali zaposlene, da oni predstavijo dogodke, $\mathrm{v}$ katerih bi želeli sodelovati, in jim nuditi podporo pri vodenju teh dogodkov. Najpomembneje pri tem je, da se vse dejavnosti načrtujejo v okviru delovnega časa. Pomembno je tudi, da se mladi zaposleni povežejo z vsemi sodelavci in ne samo s sodelavci enake starost. Ustvarjanje družbenega in zadovoljnega delovnega okolja bo veliko pripomoglo $\mathrm{k}$ ohranjanju zadovoljstva zaposlenih in ustvarjanju rezultatov za podjetje oziroma organizacijo (Millennial Boss, 2018).

Povezati se s širšim okoljem. Milenijci si ne želijo samo dobrega dela, ampak želijo delati za dobro podjetja oziroma organizacijo. Dober namen jih motivira bolj kot plača. Organizacije, ki omogočajo zaposlenim, da delajo za dobrobit širše skupnosti, imajo nižjo stopnjo fluktuacije in bolj zadovoljne zaposlene (Bertino, 2017). Raziskava podjetja Deloitte leta 2017 je pokazala, da se milenijci čutijo osebno 
povezani z velikimi vprašanji, kot sta na primer socialna nepravičnost in podnebne spremembe. Delodajalci, ki ponujajo priložnosti za sodelovanje na lokalni ravni za skupno dobro, s tem povečujejo mladim zaposlenim zadovoljstvo in jim dajejo občutek, da lahko vplivajo (Deloitte, 2017).

\section{$3 \quad$ Medgeneracijsko usklajevanje}

Vodje uspešno upravljajo s številnimi raznolikostmi, ki jih imajo zaposleni v določeni organizaciji. Te se nanašajo na spol, narodnost, socialno-ekonomsko ozadje, osebnostne lastnosti idr. Danes pa je izrednega pomena še ena raznolikost, ki jo je treba uspešno obvladovati, to je starost. Trenutno zasedajo delovna mesta dejansko štiri generacije: babyboomerji, generacija $\mathrm{X}$, katere predstavniki so že prevzeli številne vodstvene vloge, milenijci, katerih mlajši člani bodo naslednja generacija menedžerjev, in generacija Z, ki pravkar vstopa (Allen, 2017). Organizacije si prizadevajo povezati te generacije $\mathrm{v}$ kohezivno celoto, a to ni tako enostavno in marsikje predstavlja pravi izziv. Predstavniki različnih generacij se med seboj vidijo in sprejemajo drugače, kar lahko povzroči konflikte in nesporazume na delovnem mestu (Meriac, Woehr, Banister, 2010).

Babyboomerji, predstavniki generacije $\mathrm{X}$ in milenijci so v času svojega odraščanja doživeli različne socialne in zgodovinske dogodke, ki so imeli velik vpliv na oblikovanje njihovih edinstvenih perspektiv, različnih ambicij in pogledov na svet. Zaradi tega imajo tudi različen pristop do dela, ki ne sovpada vedno s pristopom drugih skupin zaposlenih. Ne glede na to, pa imajo vsi enako željo in cilj: izpolniti delovne obveznosti in prispevati k razvoju in rasti organizacije. Oviro pri doseganju ciljev pa največkrat predstavljajo različna ideologija in preference. Zato je treba k tem oviram pristopiti celostno ob upoštevanju perspektiv vseh vpletenih generacij (Phillips, 2019).

Predhodniki milenijcev, ki so v organizaciji že dlje časa, so na primer prepričani, da imajo pravico do boljših in višjih položajev pred mlajšimi zaposlenimi. Danes pa starost nima kaj dosti opraviti s tem, kje na hierarhični lestvici se nekdo nahaja. Ne glede na to, ali je trenutni vodja mlajši ali starejši, morajo zaposleni to sprejeti in se navaditi delati $\mathrm{v}$ takem poslovnem okolju. To pa velikokrat predstavlja pravi problem. 
V vsaki generaciji se najdejo posamezniki, ki gredo nekomu na živce, težko prenašajo sodelavce in še težje z njimi sodelujejo. V nadaljevanju povzemamo nekaj lastnosti starejših generacij, zaradi katerih milenijci z njimi težko sodelujejo ali celo ne želijo sodelovati.

Prepočasi se prilagajajo spremembam. Današnje delovno okolje zahteva sposobnost hitrega prilagajanja zahtevam trga. Nova tehnologija je prisotna povsod, poleg tega pa se hitro razvija. Učenje novih stvari in takojšnja uporaba le-teh sta postala osnovna zahteva sodobnega poslovanja (Freund, 2016). Milenijci so hitri, navajeni multitaskinga, hitro in učinkovito spremenijo smer, če je to potrebno. Če odkrijejo boljši proces, boljši program ali nov način, s katerim poenostavijo določeno opravilo, so se pripravljani takoj prilagoditi in sprejeti spremembe. To pa je v nasprotju s tradicijo in prepričanjem starejših generacij, ki tipično sledijo predpisanim proceduram pri uvajanju sprememb. Milenijci sovražijo ta letargični pristop in nepotrebne procedure, ki v njihovih očeh predstavljajo oviro in so tu samo zato, ker nekateri ne želijo vpeljati sprememb. Organizacije ne bi smele biti zadovoljne $\mathrm{z}$ obstoječimi procesi in procedurami, ampak bi morale stremeti $\mathrm{k}$ neprestanim izboljšavam in spremembam, če želijo ostati konkurenčne ter zagotoviti rast in napredek.

Ne želijo se naučiti uporabljati novih tehnologij. Milenijci so bili izpostavljeni digitalnemu svetu zgodaj v svojem življenju (Betz, 2019), tako ni čudno, da stremijo $\mathrm{k}$ uporabi najnovejših tehnologij. Starejši pa se vsem tem novostim težko privajajo. Mlajši se hitreje in lažje učijo. Starejši se pogosto upirajo ali celo ne zmorejo (Freund, 2016). Bodisi zaradi tega, ker so navajeni na obstoječo tehnologijo, ker se ne zavedajo, kako lahko uporaba nove olajša opravljanje dela, ali si enostavno ne želijo izstopiti iz cone udobja in poskusiti nekaj novega. Milenijci tega ne razumejo. Ker so odraščali s tehnologijo, ne morejo dojeti, kako nekoga ne zanima zadnja, najnovejša tehnologija na trgu.

Po nepotrebnem izgubljajo čas. Predstavniki milenijcev so znani po tem, da so zelo nepotrpežljivi in da si želijo takojšnjega zadovoljstva. Zato ne prenesejo, da nekdo po nepotrebnem trati čas. Hitro se razburijo, če morajo po nepotrebnem sedeti na sestanku ali opravljati nepomembne naloge. Če želimo ohraniti njihovo zanimanje, ne smemo tratiti njihovega časa. Odstraniti moramo nepomembne aktivnosti in jih nadomestiti z novimi priložnostmi, kjer se bodo lahko izkazali (Phillips, 2019). 
Niso avtentični. Milenijci so radi med sebi enakimi. Želijo delati v krogu sorodno mislečih, ki imajo enake interese. Večina napetosti prihaja, ker predstavniki različnih generacij napačno razumejo pričakovanja drugih (The Rainmaker, 2018). Če se želijo predstavniki drugih generacij na silo prilagoditi in se pretvarjajo samo zato, da bi se lahko vključili v njihov krog, se to ne bo dobro končalo. Situacije, kjer se to zelo hitro pokaže, so po navadi vezane na tehnologijo oziroma uporabo socialnih medijev, kjer milenijci uporabljajo sleng in diskutirajo o zadnji modi. Veliko hitreje bodo sprejeli nekoga, ki je sicer drugačen, ampak se ne pretvarja in je avtentičen. Za njih je pomembno vodilo »bodi zvest sebi« (Phillips, 2019).

Pobirajo zasluge za delo celotnega tima. Milenijci so pripravljeni trdo delati na projektu, prihajati zgodaj zjutraj in delati pozno v noč ter vložiti ogromno truda za to, da bodo dosegli željene rezultate in da bo organizacija lahko ponosna. Ko pa na koncu vse zasluge za njihovo trdo delo pobere njihov vodja, ki preda končno dokumentacijo vrhnjemu menedžmentu, jim »poči« srce (Phillips, 2019). Milenijci si želijo timskega dela in so pripravljeni zasluge za dobro opravljeno delo deliti s celotnim timom, ne glede na to, kakšno vlogo imajo v timu, tudi če so vodje oni sami. Zato velikokrat ne marajo starejših nadrejenih, ki na to gledajo drugače. Zasluge gredo tistemu oziramo tistim, ki jim pripadajo, in ne le šefu.

Danes se vsak vodja podjetja oziroma organizacije zaveda, da delajo skupaj tri ali celo štiri generacije (Brooks, 2017). Za dolgoročno delovanje, poslovanje in razvoj podjetja oziroma organizacije je torej medgeneracijsko povezovanje in usklajevanje izrednega pomena. Medgeneracijsko sodelovanje dobiva na veljavi predvsem zaradi prepletanja toliko različnih generacij tako v poslovnem kot tudi bivalnem okolju, zato je nujna njihova kolaboracija (Tadina, 2019). Predstavniki različnih generacij bi morali med seboj sodelovati, prenašati znanja in mentorirati drug drugega ter se tako učiti.

Področja, na katera moramo biti na delovnem mestu še posebej pozorni, so sledeča:

Medgeneracijska komunikacija. Vsaka generacija ima svoje lastne komunikacijske sloge in želje. Predstavniki babyboomerjev in generacije $\mathrm{X}$ raje komunicirajo iz oči v oči in se pogovarjajo, medtem ko milenijci menijo, da pametni telefoni niso namenjeni pogovoru, ampak pisanju sporočil in socialnim medijem (Prevue, 2014). Milenijci so zelo direktni in imajo radi hitro in zgoščeno komunikacijo. Babyboomerji bi se pogovarjali in so se pripravljeni zato celo peljati 
v drug kraj in porabiti ogromno časa samo zato, da bi se lahko srečali s svojim sogovornikom iz oči v oči. Generacija X je nekje vmes in se poslužuje komunikacije, ki se jim zdi za določen namen najbolj učinkovita. Samo zato, ker znajo ljudje govoriti, ne pomeni, da znajo komunicirati. Zato je zelo pomembno, da se pogovorimo o stilih komuniciranja, ki naj se uporabljajo $\mathrm{v}$ določenih situacijah, kot na primer med sestanki idr.

Timsko delo in sodelovanje. Babyboomerii, predstavniki generacije X in milenijci imajo vsak svoj pogled na timsko delo in sodelovanje, kar lahko ogrozi produktivnost, če jih ustrezno ne usmerjamo. Babyboomerji so samozavestni, neodvisni in samostojni (Kane, 2018b). Sicer ne nasprotujejo delu v timu, ampak nimajo ravno velike želje po tem. Menijo, da ima vsakdo svoje odgovornosti ter vloge in da bi se predstavniki mlajših generacij morali podrediti starejšim, ki imajo višji status in so v organizaciji že dlje časa. Predstavniki generacije $\mathrm{X}$ radi delajo tako sami kot $\mathrm{v}$ timu. $\mathrm{V}$ času odraščanja so bili vajeni samote in tudi vključevanja $\mathrm{v}$ razne skupine. Tako se dobro znajdejo v obeh okoljih: $v$ timu, brez težav pa delajo tudi sami. Ena od sprememb v pristopih $\mathrm{k}$ izobraževanju v času, ko so v šolo hodili milenijci, je bil večji poudarek na timskem delu in skupinskih projektih. Od osnovne šole skozi srednjo šolo in tudi kasneje je bilo običajno, da se je od članov te generacije zahtevalo, da opravijo naloge kot del ekipe oziroma tima (Heathfield, 2019). Milenijci se zato radi družijo v timu in so željni sodelovalnega okolja. Cenijo timsko delo in uživajo $\mathrm{v}$ doprinosih vsakega posameznika $\mathrm{k}$ uspehu tima in $\mathrm{s}$ tem tudi celotne organizacije.

Glede na generacijske raznolikosti je pri timskem delu smiselno upoštevati sledeče (povzeto po Phillips, 2019):

- Postaviti moramo osnova pravila delovanja, da bo vsak vedel, kaj se od njega pričakuje. Ta pravila veljajo enako za vse, ne glede na starost in njihov položaj v organizacijski hierarhiji.

- Vsak v timu mora imeti pravico glasovanja, ne glede na starost in staž v organizaciji. Ljudje so veliko bolj zainteresirani za opravljanje svojega dela, če se zavedajo, da so vpleteni in da tudi njihov glas šteje.

- Razložiti moramo zakaj. Vsakdo mora točno vedeti, zakaj so bile sprejete določene odločitve. To bo zagotovilo večjo angažiranost in predanost vseh članov tima. 
- Namenoma moramo premešati predstavnike različnih generacij med seboj. Zaposleni različnih generacij imajo edinstvene izkušnje, zanimanja, različne sposobnosti in spretnosti, ki jih prinesejo $\mathrm{v}$ tim. Tako bomo omogočili prenos znanja in sposobnosti iz ene generacije na drugo, v obe smeri.

- Zagotoviti moramo učinkovito izrabo časa. Milenijci si ne želijo dolgih ur v organizaciji in izgubo časa s poslušanjem izpetih zgodb. Babyboomerji niso navdušeni nad »team buildingom« in podobnimi skupinskimi aktivnostmi. Predstavniki generacije X pa si ne želijo biti ujeti nekje vmes.

Načini motiviranja. Babyboomerji so izjemno pridni, motivirajo pa jih denar, položaj, ugodnosti in prestiž. Uživajo dolge delovne tedne, veliko jim pomenijo poklicni dosežki (Kane, 2018b) in spoštovanje s strani kolegov (Gurchiek, 2016). Za predstavnike generacije $\mathrm{X}$ je značilno, da visoko vrednotijo kakovostno življenje, prijetno delovno okolje, samostojnost in svobodo. Lahko jim ponudimo lepo pisarno, parkirno mesto, fleksibilen delovni čas ter visoko plačo (Bertoncelj, 2019). Milenijce lahko motiviramo s prilagodljivim delovnim časom in okoljem, ker praktično ne ločijo poklicnega in zasebnega življenja (Deal in Levenson, 2015). Ker se želijo učiti in rasti, jih motivirajo povratna informacija, priznanje s strani šefa, možnosti za usposabljanje, mentorstvo, coaching in tudi pozitivna kultura delovnega okolja (Gurchiek, 2016; Middleton, 2017).

\section{$4 \quad$ Zaključek}

Vsaka organizacija si danes želi biti uspešna, imeti visoko stopnjo produktivnosti in profesionalizma. Če želi to doseči, mora biti izjemno prilagodljiva in pripravljena na neprestano spreminjanje. Pri tem mora biti pozorna na številne poslovne dejavnike. Eden ključnih dejavnikov pa so ravno njeni zaposleni oziroma delovna sila.

V današnjem času v organizacijah sodelujejo najmanj tri generacije, ponekod celo pet, zato je pomembno ustvariti inkluzivno kulturo, ki ustreza različnim potrebam vsake starostne skupine. Kolizija kultur, ki se danes pojavlja na delovnih mestih, še nikoli v zgodovini ni bila tako velika. Premagovanje najrazličnejših negativnih situacij se lahko zdi nemogoča naloga, ko skušamo premagati vsa vprašanja, povezana $z$ več generacijami na delovnem mestu. Z upoštevanjem določenih smernic pa se da premostiti to generacijsko vrzel in ustvariti visoko delujočo delovno silo različnih generacij. 
Vsaka generacija s seboj prinese svoje edinstvene izkušnje, različne poglede in načine razmišljanja. Milenijci - kot danes najobsežnejša delovna sila - pri tem niso nič drugačni, razmišljajo, se obnašajo in delajo drugače kot njihovi predhodniki. Večino vodstvenih mest v podjetjih pa danes še vedno zasedajo predstavniki generacije X. Generacijske razlike in s tem povezani izzivi v podjetjh zahtevajo, da vsak vodja prilagodi vodstvena orodja in strategije na edinstven način za vsako generacijo. Pomembna kompetenca današnjih vodij je ravno sposobnost upravljanja več generacij hkrati. Zavedati se moramo, da ni enega načina vodenja, ki bi ustrezal vsem. Znati moramo izkoristi spretnosti in sposobnosti, ki jih imajo zaposleni vseh starostnih obdobij. Podjetja morajo sprejeti in ceniti raznolikost ter jo uporabiti pri gradnji svojih blagovnih znamk.

Nekateri menijo, da je predstavnike milenijcev kot najobsežnejšo generacijo delovne sile veliko težje voditi kot predstavnike prejšnjih generacij. Ne marajo nadzora, ugovarjajo, nasprotujejo, se ne bojijo in ne priznavajo avtoritete, kadar je ta vezana le na položaj in višjo starost nadrejenih. Težko ločijo poklicno in zasebno življenje. Željni so zabave, zanimivega in raznolikega dela, sicer se hitro začnejo dolgočasiti. Veliko jim pomeni prosti čas in niso pripravljeni podaljševati delovnika pozno v noč. Želijo vedeti, kaj bodo v zameno za vloženi čas, trud in energijo od organizacije dobili. Veliko jim pomeni, da delajo za podjetje, na katerega so ponosni in ki jim omogoča razvoj in napredek. Milenijci želijo vedeti in se počutiti, kot da so del nečesa večjega od njih samih. Vse to pa seveda številnim vodjam velikokrat povzroča preglavice. Vendar enotne formule za vodenje ni.

Za uspešno vodenje in usklajevanje različnih starostnih skupin je potrebno spodbujati sodelovanje in prepoznavati uspehe vseh zaposlenih, ne glede na generacijske razlike. Vodstvo si mora prizadevati za razumevanje delovnega stila vsakega posameznika in načina, kako si le-ta želi biti priznan za dosežke. Namesto kontrole, podrejanja in ukazovanja je danes za uspešno vodenje in doseganje visoke zavzetosti zaposlenih potrebno spodbujati sodelovanje in inovativnost. Smiselno je določiti skupne prioritete, da se vsi zavedajo, da sodelujejo za dosego skupnega cilja. Omogočiti je treba osebno rast slehernega posameznika v organizaciji in poskušati doseči ravnotežje med delom in življenjem, kar cenijo vse generacije. Pri tem je smiselno razmisliti o uvedbi programov obojestranskega mentorstva, kjer je vsak zaposleni mentor in mentoriranec. Veliko pozornosti je treba posvetiti definiranju ustrezne kulture podjetja, in sicer tako, da bo razumljiva in sprejemljiva za vse. Opraviti je treba raziskavo o kulturi med vsemi zaposlenimi, na vseh ravneh 
organizacije, da bi dobili 360-stopinjski pogled na kulturo. Vodilne zaposlene moramo izbrati skrbno, na osnovi njihovih izkušenj, sposobnosti, zmožnosti za rast, vodstvenega stila in sposobnosti razumevanja ljudi ter organizacijskih izzivov ter priložnosti. Nenazadnje je treba skrbeti za blaginjo zaposlenih, ki si je želijo vse generacije.

\section{Literatura}

Adkins, A. (2016). What Millennials Want From Work and Life. Pridobljeno 19. 2.2019 iz https://www.gallup.com/workplace/236477/millennials-work-life.aspx

Allen, D. (2017). The Merging of Gen X and Millennial Cultures in the Workplace. Pridobljeno 21. 2 2019 iz https://www.td.org/insights/the-merging-of-gen-x-and-millennial-cultures-in-theworkplace

Alton, L. (2017). Phone Calls, Texts or Email? Here's How Millennials Prefer to Communicate. Pridobljeno 15. 2. 2019 iz https://www.forbes.com/sites/larryalton/2017/05/11/how-domillennials-prefer-to-communicate/\#1ea3d3836d6f

AMWA (2012). Top 10 Characteristics of the Four Generations Currently in the Workforce. Journal of the American Medical Writers Association, 27(3), 143.

Appelbaum, S., Serena, M., Saphiro, B. (2005). Generation 'X' and the Boomers: An Analysis of Realities and Myths, Management Research News, 28(1), 1-33.

Au-Yong-Oliveira, M., Gonçalves, R., Martins, J., Brancob, F. (2018). The social impact of technology on millennials and consequences for higher education and leadership. Telematics and Informatics, 35, 954-963, https://doi.org/10.1016/j.tele.2017.10.007

Barsh, J., Brown, L., Kian, K. (2016). Millennials: burden, blessing, or both? Pridobljeno 13. 2. 2019 iz https://www.mckinsey.com/business-functions/organization/our-insights/millennialsburden-blessing-or-both

Becton, J. B., Walker, H. J., Jones-Farmer, A. (2014). Generational Differences in Workplace Behavior. Journal of Applied Social Psychology, 44, 175-189.

Bertocelj, F. (2019). Vodenje brez prisile - vodenje novih generacij ali utopija? Revija HR\&M. Pridobljeno 22. 2. 2019 iz https://www.planetgv.si/hrm/iz-revije/hrm-revija-december2017januar-2018-132017/vodenje-brez-prisile-vodenje-novih-generacij-ali-utopija

Bertino, J. (2017). Five Things Millennial Workers Want More than a Fat Paycheck. Pridobljeno 19. 2. 2019 iz https://www.forbes.com/sites/forbescoachescouncil/2017/10/26/five-thingsmillennial-workers-want-more-than-a-fat-paycheck/\#4114d02315a7

Betz, C. L. (2019). Generations X, Y, and Z. Journal of Pediatric Nursing, 44, A7-A8. https://doi.org/10.1016/j.pedn.2018.12.013

Bolton, R. N., Parasuraman, A., Hoefnagels, A., Migchels, N., Kabadayi, S., Gruber, T., Loureiro, Y. K., Solnet, D. (2013). Understanding Generation Y and their use of social media: a review and research agenda. Journal of Service Management, 24(3),245-267, https://doi.org/10.1108/09564231311326987

Brooks, G. (2017). Four Tips To Managing Four Generations In One Workforce. Pridobljeno 21. 2. 2019 iz https://www.forbes.com/sites/forbeshumanresourcescouncil/2017/11/01/fourtips-to-managing-four-generations-in-one-workforce/\#e9879c15a940

Carvin, B. N. (2011). The Hows and Whys of Group Mentoring. Pridobljeno 19. 2. 2019 iz https://www.nobscot.com/press/Nobscot-Industrial-Commericial-Training-The-hows-andwhys-of-group-mentoring.pdf

Corgnet, B., Hernán-González, R., Mateo, R. (2015). Cognitive reflection and the diligent worker: An experimental study of millennials. PLOS ONE, 10(10), 1-13. 
Daud, N. (2015). Determinants of Job Satisfaction: How Satisfied are the New Generation Employees in Malaysia? Procedia - Social and Behavioral Sciences, 219, 208-213. doi:https://doi.org/10.1016/j.sbspro.2016.05.007

Davis, A. (2018). Three Things Millennials Value More Than a High Salary. Pridobljeno 15. 2. 2019 iz http://theinstitute.ieee.org/ieee-roundup/blogs/blog/three-things-millennials-value-morethan-a-high-salary

Deal, J. J., Levenson, A. (2015). What millennials want from work: how to maximize engagement in today's workforce. New York: McGraw-Hill Education.

Deloitte (2017). The 2017 Deloitte Millennial Survey. Pridobljeno 12. 2. 2019 iz https://www2.deloitte.com/global/en/pages/about-deloitte/articles/millennialsurvey.html

Deloitte (2018). Millennials disappointed in business, unprepared for Industry 4.0. Pridobljeno 19. 2. 2019 iz https://www2.deloitte.com/content/dam/Deloitte/global/Documents/AboutDeloitte/gx-2018-millennial-survey-report.pdf

Deloitte (2019). Leadership development Opportunities abound. Pridobljeno 19. 2. 2019 iz https://www2.deloitte.com/us/en/pages/about-deloitte/articles/inclusion-leadershipdevelopment.html

Elliott, G. in Corey, D. (2018). Built it. United Kingdom: John Wiley \& Sons.

Ericsson (2013). Young professionals at work. Pridobljeno 18. 2. 2019 iz https://www.ericsson.com/assets/local/news/2013/4/ young-professionals-at-work.pdf

Freund, A. (2016). Millennials Adapt to Change Quickly. Pridobljeno 22. 22019 iz http://www.personalbrandingblog.com/millennials-adapt-to-change-quickly/

Fries, K. (2018). 7 Ways Millennials Are Changing Traditional Leadership. Pridobljeno 11. 2. 2019 iz https://www.forbes.com/sites/kimberlyfries/2018/01/18/7-ways-millennials-are-changingtraditional-leadership/\#38a37d6f7dae

Gravett, L., in Throckmorton, R. (2007). Bridging the Generation Gap. How to get Radio Babies, Boomers, Gen Xers and Gen Yers to Work. Virginia: Career Press.

Gurchiek, K. (2016). What Motivates Your Workers? It Depends on Their Generation. Pridobljeno 22. 2. 2019 iz https://www.shrm.org/resourcesandtools/hr-topics/behavioralcompetencies/global-and-cultural-effectiveness/pages/what-motivates-your-workers-itdepends-on-their-generation.aspx

Gursoy, D., Geng-Qing Chi, C., in Karadag, E. (2013). Generational differences in work values and attitudes among frontline and service contact employees. International Journal of Hospitality Management, 32, 40-48. doi:https://doi.org/10.1016/j.ijhm.2012.04.002

Gursoy, D., Maier, T.A. Chi, C.G. (2008). Generational differences: An examination of work values and generational gaps in the hospitality workforce. International Journal of Hospitality Management, 27, 448-458. doi:10.1016/j.ijhm.2007.11.002

Hays (2013). Gen Y and the World of Work. Pridobljeno 18. 1. 2019 iz https://social.hays.com/wpcontent/uploads/2013/10/Hays_Report_V4_02122013_online.pdf

Heathfield, S.M. (2019). 5 Tips for Managing Millennials. Pridobljeno 21. 2. 2019 iz https://www.thebalancecareers.com/tips-for-managing-millennials-1918678

Hoque, F. (2016). Adapt Or Die: Your Business's Only Options In An Evolving Economy. Pridobljeno 15. 2. 2019 iz https://www.fastcompany.com/3030618/adapt-or-die-these-are-yourbusinesss-only-options-in-an-evolving-economy

ICONIXX (2019). Surpising Attitudes Millennials Have About Total Compensation. Pridobljeno 15. $2.2019 \quad$ iz https://d3kjp0zrek7zit.cloudfront.net/uploads/attachment/file/9342/Iconixx_Whitepaper_ -_Surprising_Attitudes_Millennials_Have_About_Total_Compensation.pdf

IZZA d.o.o. (2019). Medgeneracijsko vodenje: Generacija X, Generacija Y, Generacija Z.... Pridobljeno 7. 22019 iz https://www.izza.si/medgeneracijsko-vodenje-generacija-xgeneracija-y-generacija-z.html

Jiang, J. (2018). Millennials stand out for their technology use, but older generations also embrace digital life. Pridobljeno 18. 22019 iz http://www.pewresearch.org/facttank/2018/05/02/millennials-stand-out-for-their-technology-use-but-older-generations-alsoembrace-digital-life 
Jorgensen, B. (2003). Baby Boomers, Generation X and Generation Y?:Policy implications for defence forces in the modern era. Foresight, 5(4), 41-49. https://doi.org/10.1108/14636680310494753

Kane, S. (2018a). The Common Characteristics of Generation X Professionals. The Balance Careers. Pridobljeno 9. 2. 2019 iz https://www.thebalancecareers.com/common-characteristics-ofgeneration-x-professionals-2164682

Kane, S. (2018b). Baby Boomers in the Workplace. Pridobljeno 22. 2. 2019 iz https://www.thebalancecareers.com/baby-boomers-2164681

Lissitsa, S., Kol, O. (2016). Generation X vs. Generation Y - A decade of online shopping. Journal of Retailing and Consumer Services, 31, 304-312. https://doi.org/10.1016/j.jretconser.2016.04.015

Lyons, S. T., Schweitzer, L., Ng, E. S. (2015). How have careers changed? An investigation of changing career patterns across four generations. Journal of Managerial Psychology, 30(1), 8-21.

Meriac, J. P., Woehr, D. J., Banister, C. (2010). Generational Differences in Work Ethic: An Examination of Measurement Equivalence Across Three Cohorts. Journal of Business and Psychology, 25(2), 315-324.

Middleton, W. (2017). Violent Leadership: Be A Force For Change: Disrupt. Innovate. Energize. USA: ForbesBooks

Millennial Boss (2018). 5 Things Millennials Want at Work. Pridobljeno 20. 2. 2019 iz https://millennialboss.com/2015/12/things-millennials-want-at-work/

Mustapha, Z. (2019). 5 Effective Ways to Communicate with Millennials. Pridobljeno 15. 2. 2019 iz https://www.lifehack.org/484062/5-effective-ways-to-communicate-with-millennials

$\mathrm{Ng}$, E. S. in Gossett, C. W. (2013). Career choice in Canadian public service: An exploration of fit with the millennial generation. Public Personnel Management, 42(3), 337-358.

Ng, E. S. W., Johnson, J. M. (2015). Millennials: Who are they, how are they different, and why should we care? DOI: $10.4337 / 9781783476589$. Pridobljeno 12.2 2. 2019 iz https://www.researchgate.net/publication/282368010_Millennials_Who_are_they_how_are _they_different_and_why_should_we_care

Patterson, I., Pegg, S., (2008). Marketing the leisure experience to baby boomers and older tourists. Journal of Hospitality Marketing \& Management, 18, 254-272.

Peatman, M. (2018). The iceberg of ignorance and how to flip it. Pridobljeno 14. 2. 2019 iz https://www.change-leadership.net/wp-content/uploads/2016/01/500-Words-July-2018Iceberg-of-Ignorance.pdf

Pew Research Center (2918). Millennials lead on some technology adoption measures, but Boomers and Gen Xers are also heavy adopters. Pridobljeno 18. 2. 2019 iz http://www.pewresearch.org/fact-tank/2018/05/02/millennials-stand-out-for-theirtechnology-use-but-older-generations-also-embrace-digital-life/ft_18-0424_generationtechuse_three

Phillips, K. E. (2019). Managing Millennials: The Ultimate Handbook for Productivity, Profitability, and Professionalism. New York: Routledge.

Prevue (2014). Tips to Combine a Multi-Generational Workforce. Pridobljeno 22. 2. 2019 iz https://www.prevuehr.com/resources/insights/3-tips-to-combine-a-multi-generationalworkforce

Rani, N. in Samuel, A. (2016). A study on generational differences in work values and person organization fit and its effect on turnover intention of Generation $\mathrm{Y}$ in India. Management Research Review, 39(12), 1695-1719. https://doi.org/10.1108/MRR-10-2015-0249

Stewart, J. S., Oliver, E. G., Cravens, K. S., Oishi, S. (2017). Managing millennials: Embracing generational differences. Business Horizons, 60(1), 45-54.

Sungdoo, K. (2018). Managing millennials' personal use of technology at work. Business Horizons, 61, 261-270. https://doi.org/10.1016/j.bushor.2017.11.007

Tadina, N. Z. (2019). Vodenje raznolikosti generacij v sodobnih poslovnih okoljih. Revija HR\&M. Pridobljeno 22. 2. 2019 iz https://www.planetgv.si/prikazi-starejse-izvode/hrm-revija-junij2016/vodenje-raznolikosti-generacij-v-sodobnih-poslovnih-okoljih

Tan, S. K. (2012). Generation X \& Y and Their Work Motivation. In Proceedings International Conference of Technology Management, Business and Entrepreneurship, 18-19 December 2012 (pp. 396 - 408). Melaka, Malaysia. 
$\begin{array}{llllllll}\text { Techopedia (2019). } & \text { Reverse Mentoring. Pridobljeno } & 19 . & 2 . & 2019 & \text { iz }\end{array}$ https://www.techopedia.com/definition/28107/reverse-mentoring

The Center for Generational Kinetics (2016a). Generational Breakdown: Info About All of the Generations. Pridobljeno 6. 2. 2019 iz http://genhq.com/faq-info-about-generations

The Center for Generational Kinetics (2016b). How to determine generational birth years. Pridobljeno 6. $2.2019 \mathrm{iz}$ https://genhq.com/generational_birth_years

The Center for Generational Kinetics (2016c). Marketing, Selling to and Employing Millennials (aka Gen Y). pridobljeno 13. 2. 2019 iz https://genhq.com/millennials-gen-y-generation-y-info-2/

The Rainmaker (2018). Working with Millennials. Pridobljeno 22. 2. 2019 iz https://therainmakercompanies.com/featured-news/working-with-millennials

Twenge, J. M., Campbell, S. M., Hoffman, B. J., Lance, C. E. (2010). Generational differences in work values: Leisure and extrinsic values increasing, social and intrinsic values decreasing. Journal of Management, 36(5), 1117-1142.

Wavestone (2018). Millennials and Technology in Today's Workplace. Pridobljeno 21. 22019 iz https://www.wavestone.com/en/insight/millennials-technology-todays-workplace

West, S. (2018). Meeting Millennial Expectations in these Four Areas of Technology. Pridobljeno 18. 2. 2019 iz https://www.forbes.com/sites/forbestechcouncil/2018/06/28/meetingmillennial-expectations-in-these-four-areas-of-technology/\#2c28b8074ffc

Wiley, S. (2019). Understanding Today's Workforce: Generational Differences and the Technologies $\begin{array}{llllll}\text { they Use. } & \text { Pridobljeno } & 11 . & 2 . & 2019 & \text { iz }\end{array}$ file:///D:/Downloads/Understanding_Today $\%$ E2\% $\% 0 \% 99$ s_Workforce_Generational_Di fferences_and_the_Technologies_They_Use-Sandra_Wiley.pdf

Wong, I., Penny Wan, Y., Hong Gao, J. (2017). How to attract and retain Generation Y employees? An exploration of career choice and the meaning of work. Tourism Management Perspectives, 23, 140-150. https://doi.org/10.1016/j.tmp.2017.06.003

Woo, A. (2018). The Forgotten Generation: Let's Talk About Generation X. Forbes. Pridobljeno 9. 2. 2019 iz https://www.forbes.com/sites/forbesagencycouncil/2018/11/14/the-forgottengeneration-lets-talk-about-generation-x/\#7d80f41276d5

Wright, A. D. (2016). How Millennials are Shaping Work Flexibility for Everyone. Pridobljeno 15. 2 2019 iz https://www.shrm.org/resourcesandtools/hr-topics/technology/pages/howmillennials-are-shaping-work-flexibility-for-everyone.aspx

Zakrzewski, C. (2016). The key to getting workers to stop wasting time online. The Wall Street Journal. Pridobljeno 18. 2. 2019 iz https:// www.wsj.com/articles/the-key-to-getting-workers- to-stopwasting-time-online-1457921545

Zemke, R., Raines, C., Filipczak, B., (2000). Generations at Work. New York: American Management Association.

Zimmerman, K. (2016). Modern Mentoring is the Key to Retaining Millennials. Pridobljeno 19. 2. 2019 iz https://www.forbes.com/sites/kaytiezimmerman/2016/07/18/modern-mentoring-is-thekey-to-retaining-millennials/\#e935c125fc83 


\title{
RAZŠIRJENOST PREKARNEGA DELA V DIGITALNI DOBI
}

\author{
VESNA NOVAK \\ Univerza v Mariboru, Fakulteta za organizacijske vede, Kranj, Slovenija. \\ E-pošta: vesna.novak@um.si
}

Povzetek Spremenjeni pogoji dela, skladno z zahtevami poslovanja, narekujejo drugačne pristope in oblike zaposlovanja, kar vodi do naraščanja nestandardnih oblik dela. V Sloveniji smo $\mathrm{v}$ drugi dekadi tega stoletja začeli bolj množično uporabljati izraz prekarnost, večinoma $\mathrm{v}$ neposredni povezavi z nestandardnimi oblikami zaposlitve. Zaenkrat ne obstaja univerzalna definicija pojma prekarnost, kar prinaša različne poglede in pristope $\mathrm{k}$ raziskovanju. Zato $\mathrm{v}$ prispevku najprej opredelimo pojem prekarnost. Nato se osredotočimo na razmere na trgu dela, saj je imela gospodarska kriza poleg tehnološkega razvoja velik vpliv na porast prekarnega dela. Posebno pozornost namenimo posledicam prekarnosti, ki se kažejo $\mathrm{v}$ slabšem mentalnem zdravju prekarnih delavcev, manjši ekonomski in socialni varnosti, omejenem prostem času ter na splošno $v$ omejenem občutku svobode. V zaključku razpravljamo o nevarnostih, ki jih prekarne oblike dela prinašajo, pa tudi o priložnostih, ki jih bo potrebno pravočasno izkoristiti, da se bomo lahko z novimi oblikami dela $\mathrm{v}$ digitalni dobi enakovredno kosali z globalno konkurenco.

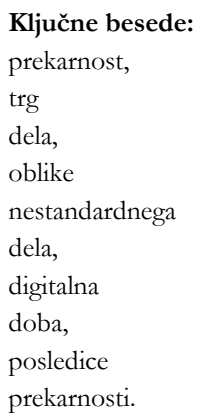




\title{
Prevalence of Precarious WORK IN THE Digital AgE
}

\author{
VESNA NOVAK \\ University of Maribor, Faculty of Organizational Sciences, Kranj, Slovenia. \\ E-mail: vesna.novak@um.si
}

\begin{abstract}
In accordance with the requirements of the business, the changed working conditions dictate different approaches and forms of employment, which leads to an increase in nonstandard forms of work. In Slovenia, we began to use the term "precariousness" more widely in direct connection with nonstandard forms of employment in the second decade of this century. So far, there is no universal definition of the concept of precariousness, which brings different views and approaches to research. Therefore, in the paper, we first define the concept of precariousness. Then we focus on the situation in the labour market, as the economic crisis has had a major impact on the rise of precarious work in addition to technological developments.

Keywords: Particular attention is paid to the consequences of precariousness, labour market, forms of non-standard work, digital age, precariousness. precariousness, which is reflected in the poor mental health of precarious workers, low economic and social security, limited leisure time and generally a limited sense of freedom. In conclusion, we discuss the dangers posed by precarious forms of work, as well as the opportunities that will need to be exploited in a timely manner so that new forms of work in the digital age can be matched by global competition.
\end{abstract}




\section{$1 \quad$ Uvod}

Četrto industrijsko revolucijo povezujemo s tehnološkim napredkom, digitalizacijo, robotizacijo in tudi z globalizacijo in vedno večjo močjo multinacionalk. Podjetja se srečujejo z zahtevami po vedno boljših poslovnih rezultatih, predvsem pa po večjem dobičku, kar v družbi vodi $\mathrm{v}$ tekmovalnost tako $\mathrm{v}$ osebnem kot poklicnem življenju. Skladno z navedenim se spreminjajo tudi načini zaposlovanja. Če je bilo delovno mesto nekoč kraj, kamor so ljudje prihajali na delo, so digitalne tehnologije omogočile, da lahko večina zaposlenih dela kadar koli in kjer koli. Vse več je nestandardnih zaposlitev, med njimi tudi oblike dela, ki jih je ustvarila nova tehnologija, npr. množični delavci (crowd workers), portfolio delavci (portfolio workers) ipd.

Tako je $\mathrm{v}$ zadnjih letih zaživelo delo preko spletnih platform, ki zajema tako preprosta dela (npr. prevozi) kot tudi zahtevnejša (npr. programiranje). Bistvo tega načina dela je, da podjetje potrebo po delu objavi preko spletnih platform in to takrat, ko potrebo zazna. Na objavo se odzovejo tisti, ki za določeno plačilo delo tudi opravijo. Delo se na tak način drobi, govorimo o fragmentaciji dela (»tasks« oz. "gigs«). Včasih zaznamo besedo "gig workers«, to so delavci, ki niso v delovnem razmerju, vendar opravljajo posamezna opravila v sklopu nekega dela. Dejstvo, da so $\mathrm{v}$ neenakem in neenakopravnem položaju, dojemajo kot nekaj povsem običajnega in se s takim stanjem celo sprijaznijo, kar lahko negativno vpliva na njihovo zdravje, doživljanje prostega časa in tudi na način življenja in celotno družbo.

V Sloveniji se je fleksibilizacija zaposlitev pričela po osamosvojitvi. Podjetja so v želji po konkurenčnosti iskala načine in poti, da bi se obdržala na trgu. Zaradi hitrih sprememb so bila »prisiljena« posegati po drugačnih - prožnostnih oblikah dela, predvsem zaradi razloga, da bi se lahko hitro in učinkovito odzvala na spremembe. $\mathrm{V}$ želji po znižanju stroškov in povečanju profita so nekatera podjetja prenesla izvajanje posameznih dejavnosti na zunanje izvajalce, s tem pa so postavila zunanje izvajalce $\mathrm{v}$ negotovost, saj ti ne vedo, kdaj namerava podjetje prekiniti sodelovanje z njimi. Spletna omrežja so še dodatno zaostrila stanje, saj predstavljajo medij, na katerem se lahko zunanji izvajalci promovirajo in tako postanejo tekmovalni, namesto povezovalni. Da bi bili za delodajalce konkurenčni in zanimivi, so po eni strani prisiljeni nižati cene svojih storitev, po drugi strani pa morajo biti stalno dosegljivi, kar pomeni, da ne poznajo meja med prostim in delovnim časom. 
Standing (2018) opisuje prav problem izgubljanja spoštovanja do prostega časa. Intenziteta dela namreč povzroča, da je človek povsem izžet (miselno in fizično). Ker je brez energije, se vdaja pasivni dejavnosti (gledanje TV, uporaba računalnika, tablice, pametnega telefona), kar lahko vodi celo v digitalno odvisnost. Nevarnost, na katero je treba opozoriti, je $\mathrm{v}$ dejstvu, da se omenjena pasivnost prenaša $v$ vse pore našega življenja, kar vodi v stanje, da prosti čas, ki ga nujno potrebujemo za regeneracijo, preživljamo čedalje manj kakovostno.

Globalizacija in digitalizacija sta omogočili, da podjetja v sklopu poslovanja nimajo več časovnih in geografskih ovir, ampak lahko poslujejo na območjih cenejše delovne sile in tam, kjer so razmere na trgu za njih ugodnejše. Ker tako stanje vpliva tudi na že zaposlene delavce, predvsem tiste, ki so zaradi nizkih plač eksistenčno ogroženi, se pogosto tudi redno zaposleni vključujejo v dodatne oblike dela, da bi si izboljšali svoj položaj, kar omenjata tudi Katz in Krueger (2019).

Če je bilo v preteklosti prekarno delo prepoznavno v okviru segmentacije dualnega trga dela in so bile negotove oblike dela prepoznavne na sekundarnem trgu dela, je danes prekarno delo razpršeno in prepoznavno tudi na primarnem trgu dela. Mnogi avtorji tako ugotavljajo, da danes pred prekarnostjo ni varen nihče. Ko govorimo o prekarnosti, navadno mislimo na oblike zaposlitve, kjer so omejene ali kršene osnovne zakonsko določene pravice dela. Ker pa prekarnost ni pravno opredeljena, so ljudje, ki delajo v prekarnih oblikah, pogosto ujeti v zanko, iz katere ne morejo izstopiti iz različnih razlogov. Med najpogostejšimi je po navadi preživetje, saj druge izbire dela nimajo. Kljub temu je treba priznati, da določenim skupinam ljudi atipične oblike dela ustrezajo, npr. mlade ženske, ki bi rade preživele več časa z otrokom in lažje usklajevale delovni čas ter poklicno in družinsko življenje, študenti, ki jim taka oblika zaposlitve predstavlja le izboljšanje finančnega stanja ali nabiranje delovnih izkušenj, upokojenci, ki si želijo izboljšati življenjski standard ipd.

$\mathrm{V}$ prispevku najprej opredelimo pojem prekarnosti, ki smo ga $\mathrm{v}$ nadaljevanju obravnavali $\mathrm{v}$ širšem pomenu besede ter glede na objektivno in subjektivno negotovost. Čeprav je objektivna negotovost tista, za katero je na voljo največ podatkov, subjektivne negotovosti ne smemo zanemariti, saj imata obe velik vpliv na kakovost življenja in družbo kot celoto. $V$ nadaljevanju predstavimo razmere na trgu dela glede nestandardnih zaposlitev. To so oblike, pri katerih je zaznati višjo stopnjo prekarnosti. Še posebej ogrožena skupina so mladi, ki jim nestandardne oblike zaposlitve onemogočajo osamosvojitev in ustvarjanje lastne družine. 
Razpravljamo tudi o posledicah prekarnosti, ki imajo negativen vpliv na posameznika, podjetja in družbo kot celoto.

\section{Opredelitev prekarnosti}

Po Dobrovoljčevi in Snoju (2016) »pridevnik prekaren izhaja iz latinske besede precarius, katere pomen je prvotno »izprošen, priberačen, začasen, odvisen od volje drugega« kasneje 'nestalen, negotov, prehoden'«. V Sloveniji je bil pridevnik "prekaren« v povezavi z delom opredeljen šele leta 2014, v drugi izdaji Slovarja slovenskega knjižnega jezika (Inštitut za slovenski jezik Frana Ramovša ZRC SAZU, 2014), in sicer: »nanašajoč se na negotovo, navadno slabo plačano začasno zaposlitev«.

Prekarnost je definirana kot značilnost prekarnega, torej jo v povezavi z delom lahko razlagamo kot negotovost, nestalnost, prehodnost. Pravne opredelitve prekarnosti ni, niti ne obstaja splošna univerzalna definicija, kar prinaša različne poglede in pristope $\mathrm{k}$ raziskovanju. Koncept prekarnega dela je bil najprej povezan $\mathrm{z}$ manj varnimi zaposlitvami. Bobek, Pembroke in Wickham (2018) pravijo, da večina avtorjev prekarno delo povezuje $z$ nestandardnimi oblikami zaposlitve, kot so delo s krajšim delovnim časom, začasno delo ali samozaposlitev, vendar obstajajo tudi avtorji, ki ponujajo širšo konceptualizacijo izraza. Čeprav ni uradnega dogovora glede opredelitve prekarnega dela, se zavedamo, da gre za kompleksno področje, zato v nadaljevanju navajamo skupne smernice, ki jih poudarjajo različni avtorji.

Vosko (2010) za prekarno delo smatra delo, ki kaže negotovost zaposlitve, nizek dohodek, majhno socialno varnost in manj drugih pravic, ki izhajajo iz dela. Podobno meni Olsthoorn (2014), ki izpostavi tri konceptualne dimenzije prekarnih zaposlitev, in sicer:

- negotove zaposlitve (npr. agencijsko delo, delo za določen čas),

- ranljive delavce (imajo omejena sredstva za preživetje) in

- okrnjene pravice (npr. pri nadomestilu za čas brezposelnosti).

Prekarna zaposlitev je tako definirana kot presečišče ranljivih zaposlenih z negotovimi zaposlitvami in majhnimi pravicami do denarnih nadomestil (slika 1). 


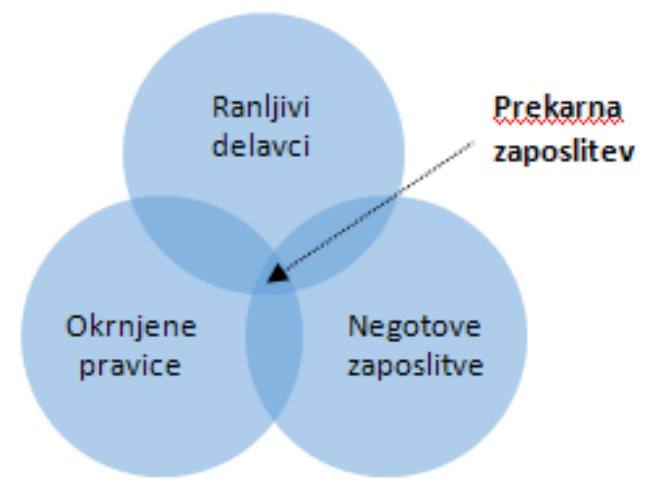

Slika 1: Konceptualni okvir prekarne zaposlitve

(Olsthoorn, 2014, str. 424)

Olsthoornova opredelitev prekarne zaposlitve je Broughtonu in sodelavcem (2016) predstavljala izhodišče za nadaljnje proučevanje prekarnosti. Za obravnavo prekarnega dela se jim zdijo najprimernejši naslednji trije pristopi:

1. Vrsta sklenjene pogodbe, ki določa tveganje negotovosti. Avtorji ugotavljajo, da so prekarne oblike zaposlitve tiste, za katere $\mathrm{v}$ povprečju velja večje tveganje negotovosti. Glede na vrsto delovnih razmerij, ki jih poznamo tudi v Sloveniji, so jih ocenili takole:

- majhno tveganje - delo s skrajšanim delovnim časom,

- srednje tveganje - delo za določen čas, samozaposlenost, občasno delo,

- srednje/visoko tveganje - agencijsko delo,

- visoko tveganje - neformalno delo, delo na črno.

2. Možnost posameznikove izbire zaposlitve. Mnoge nestandardne oblike dela posameznik izbere zato, ker mu taka oblika dela ustreza, in ne zato, ker jo je prisiljen sprejeti. Skladno s tem Poglajen (2017) trdi, da prekarno delo ne more zajemati svobodnjaštva, saj si ljudje tako obliko dela izberejo prostovoljno oz. niso pripravljeni sprejeti standardne zaposlitve za nedoločen čas. Zato je pomemben tudi razlog izbire načina zaposlitve in zadovoljstvo posameznika s svojim položajem.

3. Kvaliteta zaposlitve. Glede kvalitete zaposlitve so Broughton in sodelavci izpostavili varnost delovnega mesta, dostop do usposabljanja in poklicnega 
razvoja ter urno postavko plačila. Menimo, da ima pri proučevanju prekarnosti pomembno vlogo ukvarjanje z ljudmi in njihovimi težavami. Povsem jasno je, da lahko tudi pri delu s pogodbo za nedoločen čas zaznamo elemente prekarstva, npr. ni plač, ni plačevanja prispevkov, opravljanje nadur ipd. V tabeli 1 so predstavljene nestandardne oblike dela glede na varnost in pravice $\mathrm{v}$ primerjavi s standardno zaposlitvijo.

Iz tabele je razvidno, da so v Sloveniji najbolj prekarne oblike dela tiste, ki so sklenjene na podlagi pogodb civilnega prava in samozaposlitev. Podobno je na globalni ravni ugotovila Mednarodna organizacija dela (International Labour Organization, 2016). Največ negotovosti je zasledila med začasnim/občasnim delom, prikritimi delovnimi razmerji, lažno samozaposlenimi in podizvajalskimi oblikami zagotavljanja storitev. Sledijo odvisni zaposleni in agencijsko delo oz. posredniki dela. Med nestandardnimi oblikami dela, v katerih je negotovost še vedno pogosta, so pogodba za določen čas, projektno delo, sezonsko delo in delo za krajši delovni čas. Slednja oblika dela je glede na razširjenost negotovosti ocenjena najbolje.

Tabela 1: Pregled nestandardnih oblik dela glede na varnost in pravice $\mathrm{v}$ primerjavi $\mathrm{s}$ standardno zaposlitvijo

(prirejeno po Sindikat Mladi plus, 2017)

\begin{tabular}{|l|c|c|c|}
\hline Oblike dela & $\begin{array}{c}\text { Varnost } \\
\text { razmerja }\end{array}$ & $\begin{array}{c}\text { Delavske } \\
\text { pravice }\end{array}$ & Socialne pravice \\
\hline $\begin{array}{l}\text { Pogodba o zaposlitvi za } \\
\text { nedoločen čas }\end{array}$ & DELNO & DA & DA \\
\hline $\begin{array}{l}\text { Pogodba o zaposlitvi za } \\
\text { nedoločen čas } \\
\text { (skrajšani delovni čas) }\end{array}$ & DELNO & DA (v\%) & $\begin{array}{l}\text { Pokojninsko (\%) } \\
\text { Zdravstveno: DA }\end{array}$ \\
\hline $\begin{array}{l}\text { Pogodba o zaposlitvi za } \\
\text { določen čas } \\
\text { (polni delovni čas) }\end{array}$ & NE & DA & DA \\
\hline $\begin{array}{l}\text { Pogodba o zaposlitvi za } \\
\text { določen čas (skrajšani } \\
\text { delovni čas) }\end{array}$ & NE & NA (v \%) & $\begin{array}{l}\text { Pokojninsko (\%) } \\
\text { Zdravstveno: DA }\end{array}$ \\
\hline $\begin{array}{l}\text { Samozaposleni } \\
\text { Osebno dopolnilno delo }\end{array}$ & NE & NE & $\begin{array}{c}\text { Pokojninsko DA } \\
\text { Zdravstveno: } \\
\text { delno }\end{array}$ \\
\hline Avtorska pogodba & NE & NE & Pokojninsko (\%) \\
\hline Podjemna pogodba & NE & NE & Pokojninsko (\%) \\
\hline Študentsko delo & & Pokojninsko (\%) \\
\hline
\end{tabular}


V sklopu opredeljevanja prekarnosti omenimo tudi vedno bolj pogosto uporabljen izraz prekariat. Standing (2018) ga opredeli kot družbeno-ekonomsko skupino oz. nastajajoči nov družbeni razred, ki ga sestavljajo ljudje, ki jim manjkajo naslednje oblike varnosti, povezane $\mathrm{z}$ delom: varnost trga dela, zaposlitvena varnost, varnost službe, varnost pri delu, varnost reprodukcije veščin, dohodkovna varnost in varnost zastopništva.

Po Franci (v Poglajen, 2017) lahko prekariat obravnavamo v ožjem ali širšem smislu. V ožjem smislu prekariat zajema tiste posameznike, ki so samozaposleni ali pa delajo po civilnih pogodbah, vendar gre za prikrito delovno razmerje. Ti delavci so prepuščeni trgu dela, nimajo zajamčene minimalne plače, nimajo regresa, dopusta, pravice do bolniškega nadomestila. V širšem smislu pa prekariat zajema zaposlene $\mathrm{v}$ oblikah dela, ki nimajo enake varnosti, kot jo zagotavlja pogodba za nedoločen čas. $\mathrm{V}$ to skupino bi torej prišteli še delavce za določen čas, krajši delovni čas, agencijske delavce.

Mnogi avtorji (npr. Cranford, Vosko in Zukewich, 2003; Keller in Seifert, 2013; Poglajen, 2018) opozarjajo, da je prekarna zaposlitev relativni pojem in je natančna razmejitev vedno sporna. Avtorji namreč menijo, da prekarno delo ni omejeno samo na nestandardne oblike zaposlitve, saj ima tudi standardna oblika zaposlitve za polni delovni čas določeno tveganje prekarnosti. Ker še vedno ni enotne opredelitve pojma »prekarnost«, McKay, Jefferys, Paraskevopoulou \& Keles (2012) poudarjajo, da se izraz prekarnost pogosto uporablja povsem subjektivno za opis konkretnih izkušenj ali položaja enega ali več posameznih delavcev. Broughton in drugi (2016) pa celo opozarjajo, da je prekarno delo pogosto politizirano in se lahko spretno uporablja v kritični perspektivi, kar lahko vodi do preračunljive uporabe podatkov za lastne potrebe.

Čeprav se prekarnost večinoma omenja v povezavi z nestandardnimi oz. atipičnimi oblikami dela, se je smiselno osredotočiti na različne dimenzije prekarnosti, kot so varnost zaposlitve, socialne pravice, višina plače, intenzivnost dela. Kljub dejstvu, da sta ranljivost posameznikov in okrnjenost pravic pomembna dejavnika, smo se v nadaljevanju osredotočili predvsem na naravo delovnih mest. To je dejavnik, ki tvori ključni element prekarnosti, saj kaže na zaposlitveni položaj posameznika. Poleg tega smo imeli na voljo večino podatkov, da smo lahko primerjali posamezne oblike zaposlitve. 


\section{$3 \quad$ Razmere na trgu dela}

Čeprav smo izraz prekarnost (kot negotovost, nestalnost) v slovenskem prostoru množično sprejeli šele $\mathrm{v}$ drugi dekadi tega stoletja, to ne pomeni, da se z negotovimi, manj varnimi in slabo plačanimi zaposlitvami v Sloveniji nismo srečevali že $\mathrm{v}$ preteklosti. Po osamosvojitvi in $\mathrm{s}$ prehodom $\mathrm{v}$ tržno gospodarstvo so podjetja $\mathrm{v}$ tekmi s konkurenco začela z vpeljavo fleksibilne delovne sile. To je pomenilo, da so se lažje prilagajali razmeram na trgu dela, zniževali stroške dela oz. poviševali profit. Vse to se dogaja na račun delavcev, ki so z nestandardnimi oblikami dela sprejeli tveganje, kar se tiče stalne zaposlitve, saj se jih najema po potrebi, in kar se tiče finančne varnosti, saj so priložnostna dela pogosto slabo plačana oz. plačana z zamudo. V nekaterih oblikah, npr. agencijsko delo, študentsko delo, se pojavi še posrednik, ki izkorišča nevednost oz. neinformiranost delavca.

Glede na dejstvo, da je med najbolj dostojnimi oblikami dela zaposlitev za nedoločen čas s polnim delovnim časom, smo na sliki 2 prikazali delež zaposlitev za nedoločen čas med vsemi delovno aktivnimi v Sloveniji in povprečjem držav članic EU v zadnjih letih. Razvidno je, da Slovenija v populaciji vseh delovno aktivnih ne zaostaja veliko za povprečjem držav članic EU. Delež zaposlitev za nedoločen čas je stabilen in je v letu 2018 presegel 70 \%. Potrebno pa je upoštevati, da so med njimi tudi taki, ki so zaposleni s krajšim delovnim časom, ta oblika dela pa sodi med nestandardne oblike zaposlitve. Rečemo lahko, da se še vedno več kot $30 \%$ delovno aktivne populacije srečuje $z$ nestandardnimi oblikami dela, ki prinašajo manj varnosti ter manj delavskih in socialnih pravic $\mathrm{v}$ primerjavi s standardno obliko zaposlitve.

Ko govorimo o mladih na trgu dela, je treba najprej definirati mlade. Pri starostni omejitvi mladih si avtorji niso enotni. Na to vpliva pojmovanje mladosti kot življenjskega obdobja, polnega različnih prehodov iz otroštva v odraslost. Vertotova (2009) omenja tri glavne prehode:

- prehod od zaključka šolanja v zaposlitev oz. vstop na trg delovne sile,

- prehod od ekonomske odvisnosti k ekonomski neodvisnosti in

- prehod od bivanja pri starših v lastno domovanje. 
Starost pri teh prehodih je težko določljiva, od tod izvirajo tudi težave glede enotnosti postavljanja starostne omejitve. Združeni narodi uvrščajo med mlade tiste osebe, ki so stare od 15 do 24 let. Večina držav v EU to obdobje podaljša, nekatere le do 25. leta druge do 30. leta, Romunija celo do 35. leta. Večina držav pa je enotna v zgornji starostni meji, ki naj ne bi presegala 30 let. Mlade v Sloveniji opredeljujeta Urad RS za mladino in Zavod RS za zaposlovanje kot osebe, stare od 15 do 29 let. $\mathrm{V}$ nadaljevanju zato prikazujemo podatke za delovno aktivno populacijo in mlade, stare od 15 in do 24 let, povsod, kjer so bili podatki dostopni, pa smo posebej prikazali še starostno skupino od 25 do 29 let.

Večja negotovost glede zaposlitev se pokaže pri delovno aktivnih mladih v starostni skupini od 15 do 24 let (slika 2). Čeprav se je v Sloveniji stanje v letu 2018 izboljšalo in je delež zaposlitev za nedoločen čas $\mathrm{v}$ zadnjih sedmih letih narastel za 9,1 odstotne točke (v povprečju držav članic EU le za 0,1 odstotne točke), pa je s 30,3 \% deležem daleč pod povprečjem držav članic EU (53,8 \%). To pomeni, da je v Sloveniji več kot $70 \%$ delovno aktivnih mladih vključenih v negotove oblike zaposlitve (začasne zaposlitve, krajši delovni čas, samozaposlitev).

\begin{tabular}{|ll|}
\hline - EU-28 (15 let in več) & - Slovenija (15 let in več) \\
\hline---- EU-28 (15-24 let) & ----- Slovenija $(15-24$ let $)$ \\
\hline
\end{tabular}

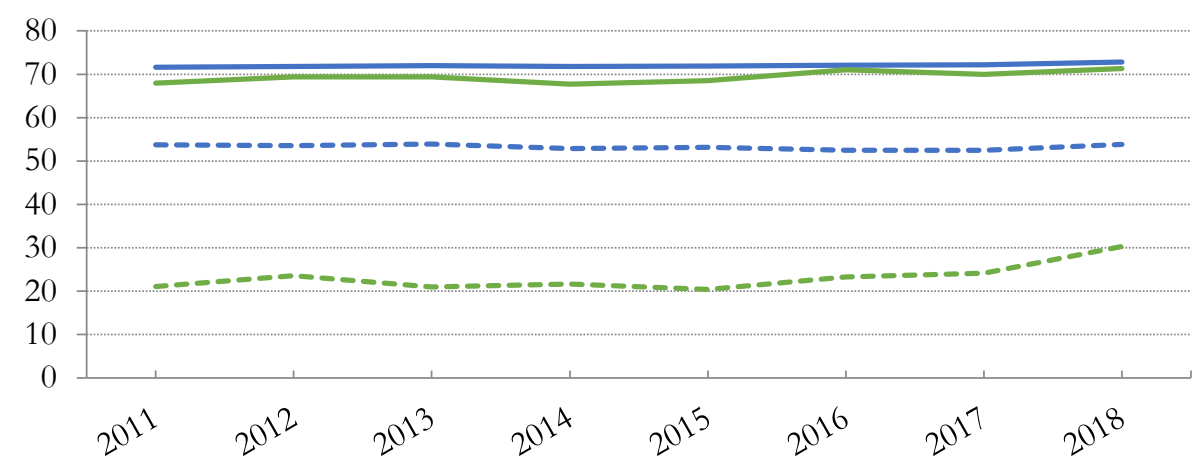

Slika 2: Delež zaposlitev za nedoločen čas med delovno aktivnimi v Sloveniji in v povprečju držav članic EU

(lastni preračuni; Eurostat, 2020a; Eurostat 2020b) 
Zaradi nizkega deleža standardne oblike zaposlitve med delovno aktivnimi mladimi v Sloveniji smo proučili, katera vrsta zaposlitve je med mladimi najpogostejša. Slika 3 prikazuje deleže delovno aktivnih mladih v starostni skupini od 15 do 24 let glede na vrsto zaposlitve v obdobju zadnjih desetih letih. Razvidno je, da je za mlade v vsem desetletnem obdobju najpogostejša oblika zaposlovanja delo preko študentskega servisa kljub rahlemu odstopanju v deležu te zaposlitve. Med rednim delovnim razmerjem pa je zaznati visok delež zaposlitev za določen čas. Tako je leta 2011 in 2015 razmerje v korist redni zaposlitvi za določen čas, enak delež zaposlitve za nedoločen in določen čas je zaznati v letih 2012 in 2016, v preostalih letih pa je razmerje v korist zaposlitve za nedoločen čas. Pri redni zaposlitvi beležimo v letu 2018 večji delež v korist delovnega razmerja za nedoločen čas. Med delovno aktivno mladino je imelo to obliko zaposlitve 30,3\% mladih, 20,5\% je bilo zaposlenih v rednem delovnem razmerju za določen čas. Predvidevamo, da je na razmere močno vplivala gospodarska rast, saj so se mnoga podjetja srečevala z deficitom kadrov in posledično se je ponudba delovnih mest za sklenitev delovnega razmerja za nedoločen čas povečala. Še vedno je med delovno aktivnimi mladimi prevladujoča oblika študentsko delo z 39,5\% deležem, 7,2 \% mladih dela v drugih oblikah dela in kot pomagajoči družinski člani, 2,5\% mladih pa sta samozaposlena.

$\square$ Samozaposleni
Mladi v drugih oblikah dela in kot pomagajoči družinski člani
Delo prek študentskega servisa
Mladi v delovnem razmerju za določen čas
Mladi v delovnem razmerju za nedoločen čas

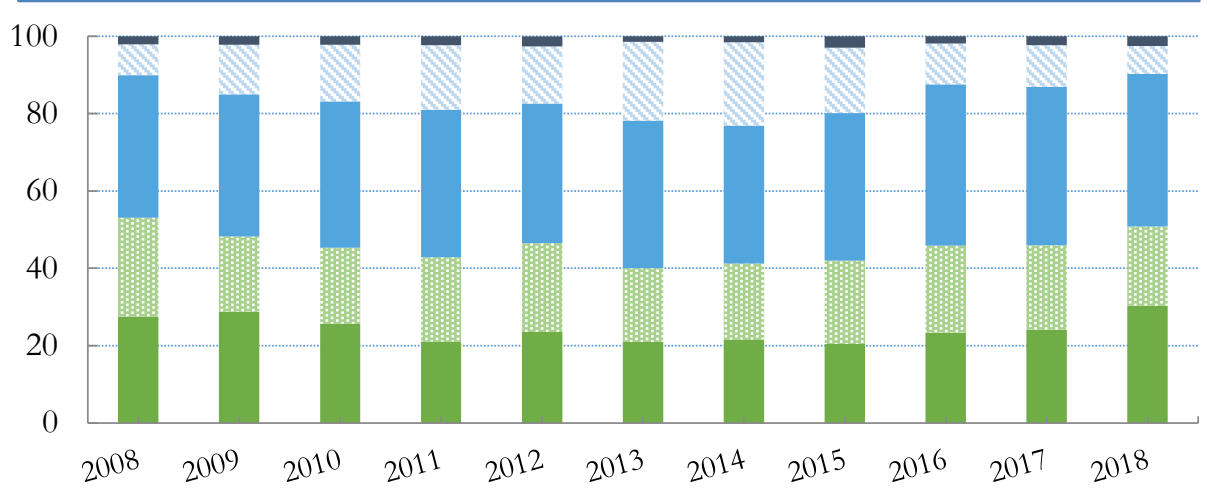

Slika 3: Delež delovno aktivnih mladih glede na vrsto zaposlitve v starostni skupini od 15 do 24 let v Sloveniji

(lastni preračuni; SURS, 2019; Eurostat, 2020b; Eurostat 2020c) 
V naslednjih poglavjih predstavljamo stanje zaposlenosti $v$ najpogostejših oblikah nestandardnih zaposlitev, tako za celotno delovno aktivno populacijo kot za mlade $\mathrm{v}$ Sloveniji in v povprečju držav članic EU.

\section{Samozaposleni na trgu dela}

Samozaposleni so tisti, ki opravljajo neodvisno, samostojno delo v lastnem podjetju, kmetijstvu ali poklicni praksi z namenom zaslužka dobička. Prednosti, ki jih prinaša samozaposlitev, so svoboda in popoln nadzor pri delu, možnost uresničevanja lastnih zamisli in idej, možnost prilagajanja delovnega časa, višine zaslužka in položaja. Ovire so predvsem v večjem tveganju, odgovornosti, pomanjkanju finančnih sredstev in slabši socialni varnosti.

Slika 4 prikazuje delež samozaposlenih med delovno aktivnimi $\mathrm{v}$ treh starostnih skupinah: 15 let in več, od 15 do 24 let in od 25 do 29 let v Sloveniji in v povprečju držav članic EU. V Sloveniji je $\mathrm{v}$ vseh starostnih skupinah delež samozaposlenih pod povprečjem deleža samozaposlenih $\mathrm{v}$ državah članicah EU. Izjema so bili mladi med 25. in 29. letom starosti v letih 2014 in 2015, pri katerih je bil delež samozaposlenih večji od povprečja držav članic EU. Razlog lahko poiščemo v dejstvu, da je bila $\mathrm{v}$ tem obdobju brezposelnost te starostne skupine med bolj problematičnimi v EU (leta 2014 na 7. mestu, leta 2015 na 6. mestu), zato se je več mladih odločalo za samozaposlitev, tudi ob pomoči subvencij države, ki je tako ublažila situacijo naraščajoče brezposelnosti mladih. Kljub temu je delež samozaposlenih tako v povprečju držav članic EU kot v Sloveniji mnogo višji v skupini 15 let in več in najnižji v starostni skupini od 15 do 24 let. V letu 2018 je tako delež samozaposlenih v starostni skupini 15 let in več $12,5 \%$, v povprečju držav članic EU pa 14,3 \%. Razkorak v deležu samozaposlenih med povprečjem držav članic v EU in Slovenijo je najmanjši v starostni skupini od 25 do 29 let, in sicer znaša delež samozaposlenih v Sloveniji 7,1 \%, v povprečju držav članic EU pa 7,9 \%. Delež samozaposlenih je najmanjši v skupini od 15 do 25 let, in sicer v Sloveniji $2,5 \%$, v povprečju držav članic EU pa 3,9\%.

Podatki samozaposlenosti kažejo, da se za to obliko dela v Sloveniji v primerjavi s povprečjem držav članic EU odloča manj delovno aktivnih v vseh proučevanih starostnih skupinah. Po drugi strani pa je v letih 2008 do 2018 delež samozaposlenih $\mathrm{v}$ vseh starostnih skupinah v povprečju držav članic EU konstanten, medtem ko v Sloveniji narašča. Tako je v celotni populaciji delež samozaposlenih narasel za 2,6 
odstotnih točk, med mladimi v starostni skupini od 15 do 24 let za 0,4 odstotnih točk in največ v starostni skupini od 25 do 29 let za 3,5 odstotnih točk, k čemur so pripomogle tudi subvencije samozaposlitve za mlade do 28 . leta.

Omeniti je treba, da delodajalci večkrat zlorabljajo institut samozaposlovanja, namesto da bi sklenili redno delovno razmerje. Zato je naraščanje samozaposlenosti problematično predvsem takrat, ko ne gre za podjetništvo, temveč za prikrito delovno razmerje. Delodajalec se na tak način izogne vsem obveznostim, ki so povezane z neposredno zaposlitvijo (npr. stroški plač in prispevkov), in jih prenese direktno na delavca. Zato je t. i. »lažna samozaposlitev« tista, ki je med nestandardnimi oblikami zaposlitve ocenjena z največ negotovosti in tveganj.

\begin{tabular}{|ll|}
\hline$\cdots \cdots \cdots$ EU $-28(15-24$ let $)$ & $\cdots--$ EU $-28(25-29)$ \\
$\ldots$ EU $-28(15$ let in več $)$ & $\cdots \cdots$ Slovenija $(15-24$ let $)$ \\
$\ldots \cdots$ Slovenija $(25-29$ let $)$ & Slovenija $(15$ let in več $)$ \\
\hline
\end{tabular}

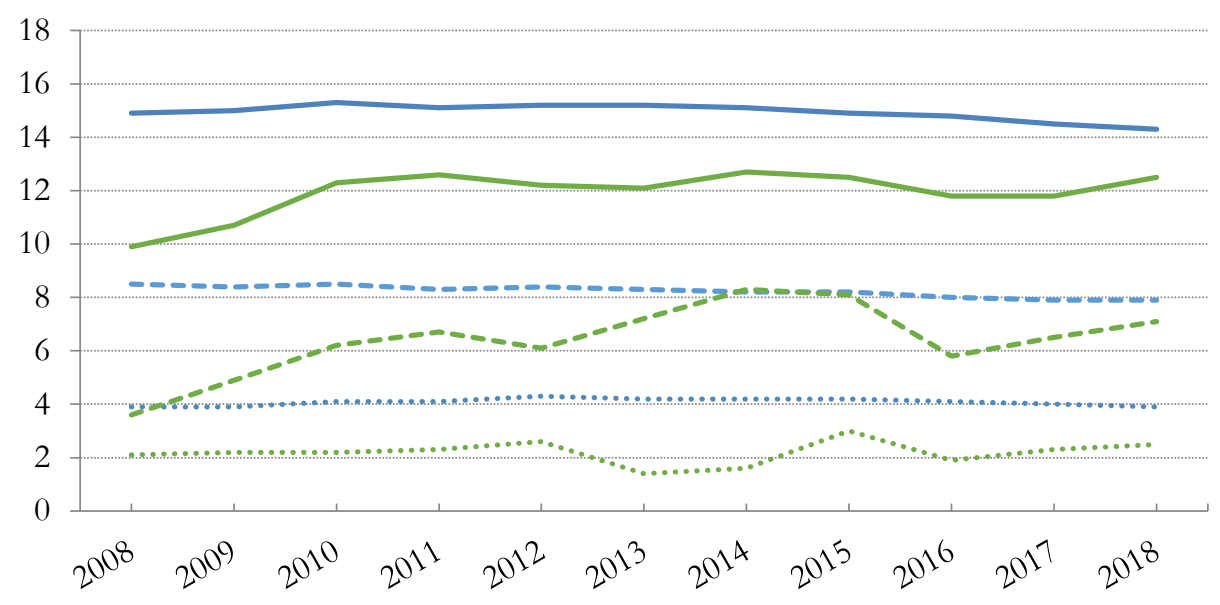

Slika 4: Delež samozaposlenih med vsemi delovno aktivnimi v Sloveniji in v povprečju držav članic EU

(lastni preračuni; Eurostat, 2020b; Eurostat, 2020c) 


\section{Začasno zaposleni na trgu dela}

Začasno zaposleni so tisti, ki so zaposleni v delovnem razmerju za določen čas in $\mathrm{v}$ vseh drugih oblikah dela, ki so začasne (npr. delo preko agencij za posredovanje dela, vključujoč študentsko delo, delo preko avtorskih pogodb, podjemnih pogodb ipd.). Prednosti za začasno zaposlene se kažejo predvsem v večji prilagodljivosti. Mladim ta oblika zaposlitve nudi pridobivanje delovnih izkušenj, nova poznanstva, mreženje ter priložnost za stalno zaposlitev in izboljšanje finančne situacije. Slabosti začasnih zaposlitev pa se kažejo predvsem v negotovosti, kar vpliva na zdravje posameznika in možnost ujetosti v krog prekarnosti.

Na sliki 5 so prikazani deleži začasno zaposlenih v različnih starostnih skupinah za obdobje od 2008 do 2018 v Sloveniji in v povprečju držav članic EU. Primerjava Slovenije s povprečjem držav članic EU pokaže, da je v vseh proučevanih starostnih skupinah delež začasnih zaposlitev v Sloveniji večji kot v povprečju držav članic EU. Razkorak med njima je največji v skupini mladih med 15. in 24. letom (za leto 2018 je povprečje držav članic EU 43,5 \%, v Sloveniji pa $67 \%$ ), sledijo mladi med 25. in 29. letom (za leto 2018 je povprečje držav članic EU 22,5 \%, v Sloveniji $31 \%$ ). V starostni skupini 15 let in več je razlika konstantno majhna (za leto 2018 je povprečje držav članic EU 14,1 \% in v Sloveniji 15,1 \%). Primerjava stanja v Sloveniji kaže, da deleži odražajo stanje na trgu dela, saj se delodajalci za začasno obliko odločajo pogosteje $\mathrm{v}$ neugodnih gospodarskih razmerah. Tako je v letu 2018 opaziti zmanjšanje začasnih zaposlitev $v$ vseh starostnih skupinah, najbolj med mladimi. V starostni skupini od 15 do 24 let je upad v primerjavi z letom 2017 za 5,5 odstotnih točk, v skupini med 25. in 29. letom pa za 5,3 odstotnih točk. Kot smo že omenili, je razlog v večjem povpraševanju delodajalcev, ki v želji po zapolnitvi delovnega mesta ponujajo več delovnih mest za nedoločen čas, da bi si zagotovili kader in tako lahko normalno poslovali. 


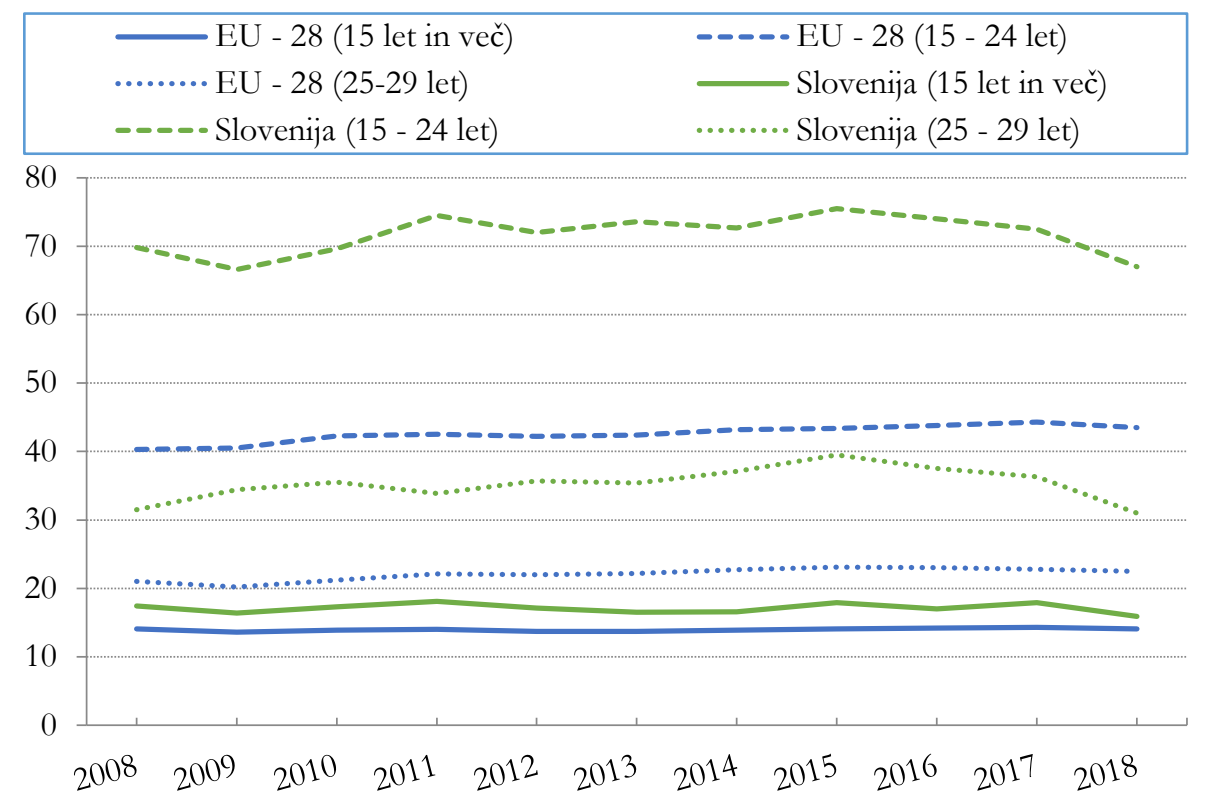

Slika 5: Delež začasno zaposlenih med vsemi zaposlenimi v Sloveniji in v povprečju držav članic EU

(Eurostat, 2020d; Eurostat, 2020e)

Že s slike 3 je razvidno, da je za mlade v skupini od 15 do 24 let študentsko delo najobširnejša oblika dela v celotnem obdobju od 2008 do 2018. Zato so nas zanimali še razlogi začasne zaposlitve mladih ter razlogi vseh začasno zaposlenih v Sloveniji in v povprečju držav članic EU za leto 2018 (slika 6). V Sloveniji je v starostni skupini 15 let in več najpogostejši razlog za začasno zaposlitev, da si stalne zaposlitve niso želeli (46,9 \%), v povprečju držav članic EU je ta razlog šele na tretjem mestu $(13,5 \%)$. Na drugem mestu je v Sloveniji razlog, da ni bilo mogoče dobiti stalne zaposlitve (39,6 \%), v povprečju držav članic EU pa je to najpogostejši razlog začasne zaposlitve, in sicer je ta razlog navedlo kar 52,2 \% začasno zaposlenih. Razlog »zaradi procesa izobraževanja in usposabljanja« je v povprečju držav članic EU drugi najpogostejši razlog $(14,4 \%)$, v Sloveniji pa je ta razlog šele na četrtem mestu (3,3\%). V Sloveniji je med mladimi od 15 do 24 let vrstni red razlogov začasne zaposlitve enak kot pri skupini 15 let in več, vrednosti pa so precej drugačne. Tako kar $74 \%$ mladih ne želi stalne zaposlitve, 16,5 \% je izbralo začasno zaposlitev, ker stalne niso mogli dobiti, sledi poskusno obdobje (5,6\%) in na četrtem mestu zaradi procesa izobraževanja in usposabljanja 3,9 \%. V povprečju držav članic EU 
je pri mladih na prvem mestu razlog "proces izobraževanja in usposabljanja« $(34,7$ $\%$ ), sledi razlog, da niso mogli dobiti zaposlitve $(29,7 \%)$ in šele na tretjem mestu zaradi tega, ker niso želeli stalne zaposlitve (16,6\%).

Seveda rezultati razlogov za sprejem začasne zaposlitve $\mathrm{v}$ veliki meri spremeni sicer negativno podobo standardne oblike zaposlitve med mladimi med 15. in 24. letom. Glede na podatke Statističnega urada RS (SURS, 2019), da ima med zaposlenimi delovno razmerje za nedoločen čas le $33 \%$ zaposlenih, bi lahko predvidevali, da so mladi prisiljeni izbirati nestandardne oblike zaposlitve. Dejstvo, da kar 3/4 mladih izbere začasno zaposlitev, ker si to želijo, pa taka predvidevanja ovrže. Poudarili bi, da je mladim v Sloveniji omogočeno študentsko delo, ki je najbolj obsežna oblika zaposlitve med mladimi. Gre za začasno in občasno obliko dela, ki je za delodajalce v Sloveniji zaradi nebirokratskih postopkov zelo priljubljena. V primerjavi z drugimi oblikami dela, ki so na voljo mladim brez statusa, imajo študenti večjo možnost dobiti delo. Slaba stran dela preko študentske napotnice je izkoriščanje statusa študenta samo zaradi dela, kar se pogosto kaže kot fiktivni vpis.

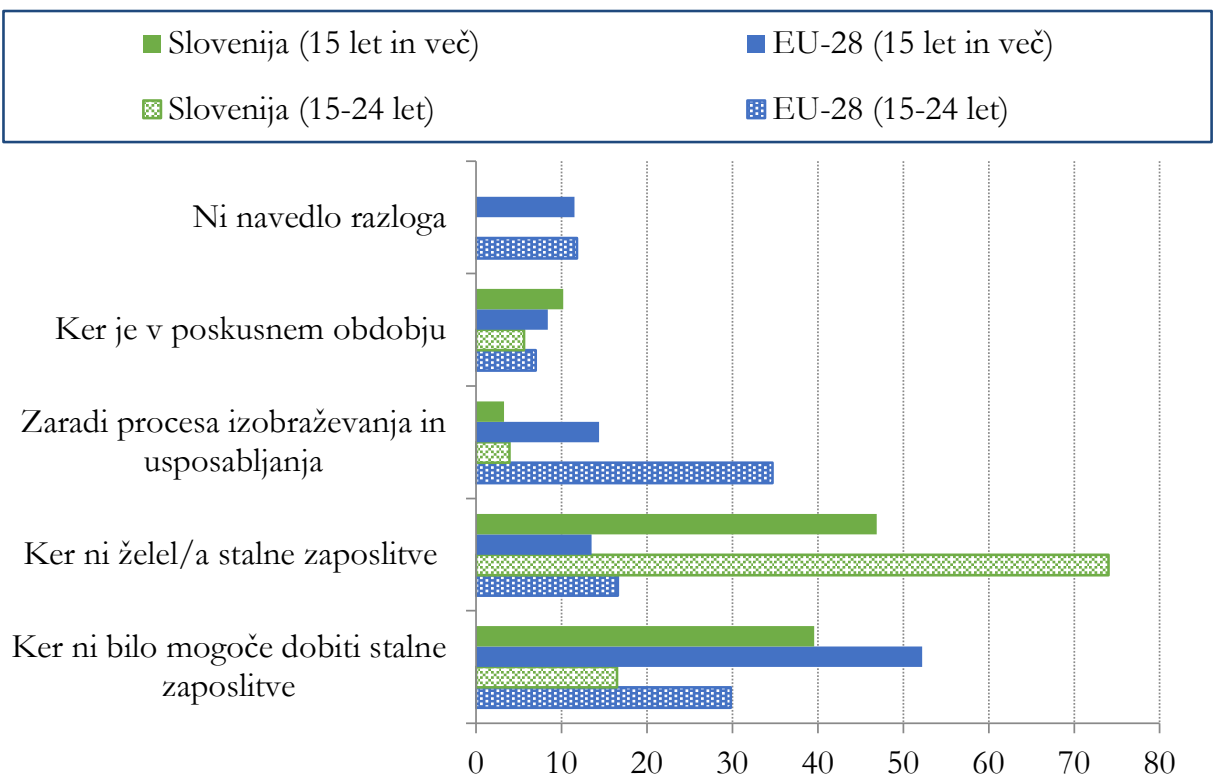

Slika 6. Deleži začasno zaposlenih glede na razlog začasne zaposlitve v Sloveniji in povprečju držav članic EU za leto 2018

(Eurostat, 2020f) 


\section{Zaposleni za krajši delovni čas}

Pod zaposlene za krajši delovni čas smatramo zaposlene $z$ delovnim časom, ki je krajši od polnega delovnega časa. V državah zahodne Evrope je to zelo priljubljena oblika zaposlitve, predvsem pri ženskah, saj jim nudi usklajevanje družinskega in poklicnega življenja. Naslednja prednost te oblike zaposlitve je, da je primerna za ljudi z zdravstvenimi težavami, ki na tak način ostanejo še vedno zaposleni, ter da starejšim omogoča razbremenitev glede dolžine delovnega časa. Mladim ta oblika predstavlja izvrstno možnost nabiranja delovnih izkušenj med študijem, s tem pa jim lahko olajša prehod v redno zaposlitev za polni delovni čas.

Slika 7 prikazuje delež zaposlenih za krajši delovni čas v obdobju med 2008 in 2018 v Sloveniji in v povprečju držav članic EU za mlade in vse zaposlene. Primerjava Slovenije s povprečjem držav članic EU pokaže, da je v proučevani starostni skupini 15 let in več ter skupini mladih med 25. in 29. letom delež zaposlitev za krajši delovni čas v Sloveniji precej nižji kot v povprečju držav članic EU. Razkorak med njima je $\mathrm{v}$ vsem desetletnem obdobju stalen, največji je v skupini vseh zaposlenih (za leto 2018 v povprečju držav članic EU 20,1 \% in v Sloveniji 10,6 \%), pri mladih med 25. in 29. letom pa malo manjši (za leto $2018 \mathrm{v}$ povprečju držav članic EU 16,2 \%, v Sloveniji pa 10,8 \%). Pri mladih med 15. in 24. letom je delež zaposlenih s krajšim delovnim časom večji v Sloveniji kot v povprečju držav članic EU, v letu 2017 v Sloveniji 37,5 \%, v povprečju držav članic EU pa 32,3 \%, za leto 2018 se je razlika zmanjšala (v Sloveniji 33,5 \%, v povprečju držav članic EU 32,2 \%). 


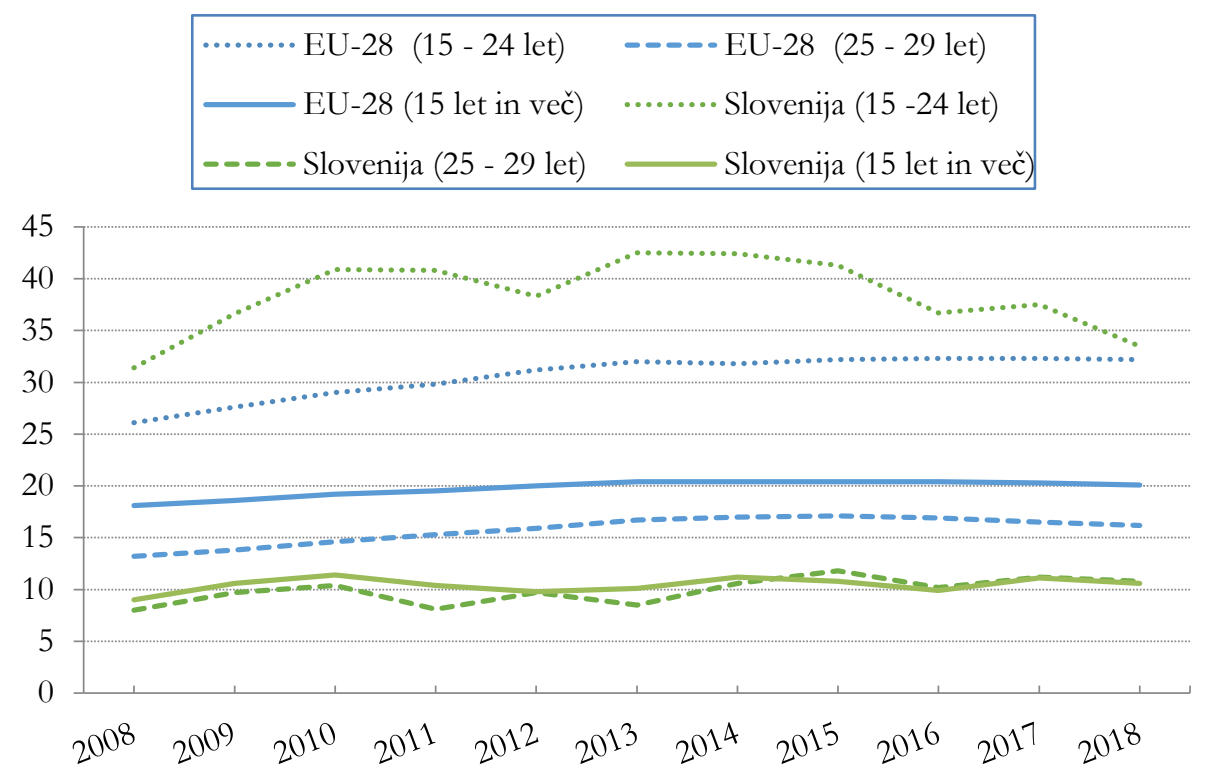

Slika 7: Deleži zaposlenih za krajši delovni čas v Sloveniji in v povprečju držav članic EU (Eurostat, 2020g; Eurostat, 2020h)

Zanimali so nas tudi razlogi začasne zaposlitve mladih ter razlogi vseh začasno zaposlenih v Sloveniji in v povprečju držav članic EU, ki so za leto 2018 prikazani na sliki 8. V Sloveniji je med vsemi zaposlenimi najbolj pogosto naveden razlog za zaposlitev s krajšim delovnim časom: »zaradi lastne bolezni ali invalidnosti« (25,2\%), v povprečju držav članic EU je ta razlog šele na zadnjem mestu (4,5\%). Na drugem mestu je v Sloveniji razlog »zaradi procesa izobraževanja ali usposabljanja« (20,5\%), v povprečju držav članic EU je na predzadnjem mestu (10,7 \%). Na tretjem mestu je v Sloveniji razlog »zaradi skrbi za otroke ali odraslih nezmožnih oseb« $(11,1 \%)$. V povprečju držav članic EU je to drugi najpogostejši razlog (20,8 \%). Na prvem mestu v povprečju držav članic EU je razlog, da »ni bilo mogoče dobiti stalne zaposlitve« (23,2\%), v Sloveniji pa je ta razlog zaposlitve za krajši delovni čas na predzadnjem mestu (6\%). Med mladimi od 15 do 24 let je v Sloveniji in v povprečju držav članic EU najpogostejši razlog za zaposlitev s krajšim delovnim časom enak, to je "proces izobraževanja ali usposabljanja« (v Sloveniji 80,8 \%, v povprečju držav članic EU 61,1 \%). Na drugem mestu v povprečju držav članic EU je razlog, da »stalne zaposlitve niso mogli dobiti« (22,6\%). Pri mladih v Sloveniji pa pri tem razlogu podatki zaradi nizke zanesljivosti niso navedeni. 
Predvidevamo, da so v Sloveniji mladi izbrali razlog »zaradi procesa izobraževanja ali usposabljanja « tako veliki meri, ker je za mlade po 19. letu starosti študij postal način življenja. V Sloveniji je število vpisnih mest na visokošolske zavode večje kot število dijakov, ki zaključijo srednje šole. V Sloveniji se namreč več kot $90 \%$ dijakov, ki so končali sekundarno izobraževanje in izpolnjevali pogoje za vpis $\mathrm{v}$ študijske programe, vpisuje v terciarno izobraževanje. Medveš in Muršak (2010) nadaljevanje izobraževanja na terciarni ravni $\mathrm{v}$ Sloveniji razlagata kot odgovor mladih na nevarnost družbene marginalizacije, ki sledi tistim z doseženo zgolj nižjo ali srednjo poklicno izobrazbo. Problem je namreč $\mathrm{v}$ dejstvu, da zaposlovanje na ravni kvalificiranega dela ne zagotavlja niti družbenega ugleda niti dohodka nad pragom revščine. Potrebno pa je poudariti tudi dejstvo, da mladi večkrat »izrabljajo« vpis v višje in visoke šole zaradi dela in ne zaradi namena študija.

\begin{tabular}{|c|c|}
\hline - Slovenija (15 let in več) & EU-28 (15 let in več) \\
\hline 图Slovenija (15-24 let) & 四 EU-28 (15-24 let) \\
\hline
\end{tabular}

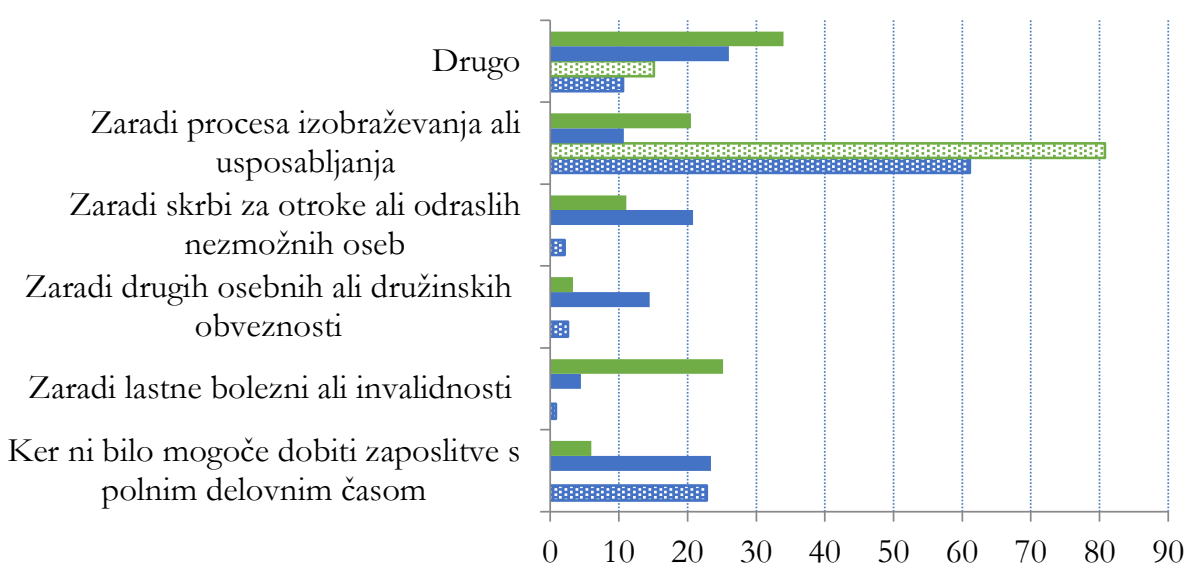

Slika 8: Deleži zaposlenih za krajši delovni čas glede na razlog v Sloveniji in v povprečju držav članic EU v letu 2018

(Eurostat, 2020i)

\section{Začasno agencijsko delo}

Agencijsko delo označuje obliko dela, ki nastane s sklenitvijo pogodbe o zaposlitvi med delavcem in delodajalcem, ki je $\mathrm{v}$ tem primeru agencija. Njihovo razmerje je tripartitno. Podjetje, v katerem bo delavec opravljal delo, pa je le uporabnik, ki sklene pisni dogovor $\mathrm{z}$ agencijo. $\mathrm{V}$ dogovoru agencija in podjetje določita medsebojne 
pravice in obveznosti ter pravice in obveznosti delavca in uporabnika. Prednosti, ki jih taka oblika prinaša podjetjem, so večja prilagodljivost glede potreb po delavcih, prihranek časa in stroškov pri iskanju delavcev, nižji stroški dela, manj tveganj, ki jih sicer zaznamo v standardni obliki zaposlitve. Pri delavcih bi lahko kot prednost agencijskega dela omenili možnost kasnejše neposredne zaposlitve v podjetju, saj posameznik podjetje spozna in se lahko med delom izkaže. Med slabostmi pa lahko omenimo, da je večina agencijskih del slabo plačanih in zahteva nižjo kvalifikacijo ter slabe možnosti napredovanja in stigmatiziranost.

Na sliki 9 so prikazani deleži začasnih agencijskih delavcev v Sloveniji in v povprečju držav članic EU. Razvidno je, da je delež agencijskih delavcev med vsemi zaposlenimi v obdobju od 2008 do 2018 v Sloveniji permanentno višji od povprečja držav članic EU. Stanje glede agencijskega dela se v povprečju držav članic EU v zadnjih dveh letih ni spremenilo, v Sloveniji pa je zaznati ponovno rast agencijskega dela $\mathrm{v}$ zadnjih dveh letih, in sicer predvsem zaradi gospodarske rasti, večjega povpraševanja po delavcih in zaradi težav, ki so jih podjetja imela pri iskanju delavcev. Nenazadnje se podjetja $z$ agencijskim delom lažje prilagajajo situaciji na trgu dela in si tako zmanjšujejo tveganja, ki jim jih sicer prinaša sklenitev rednega delovnega razmerja.

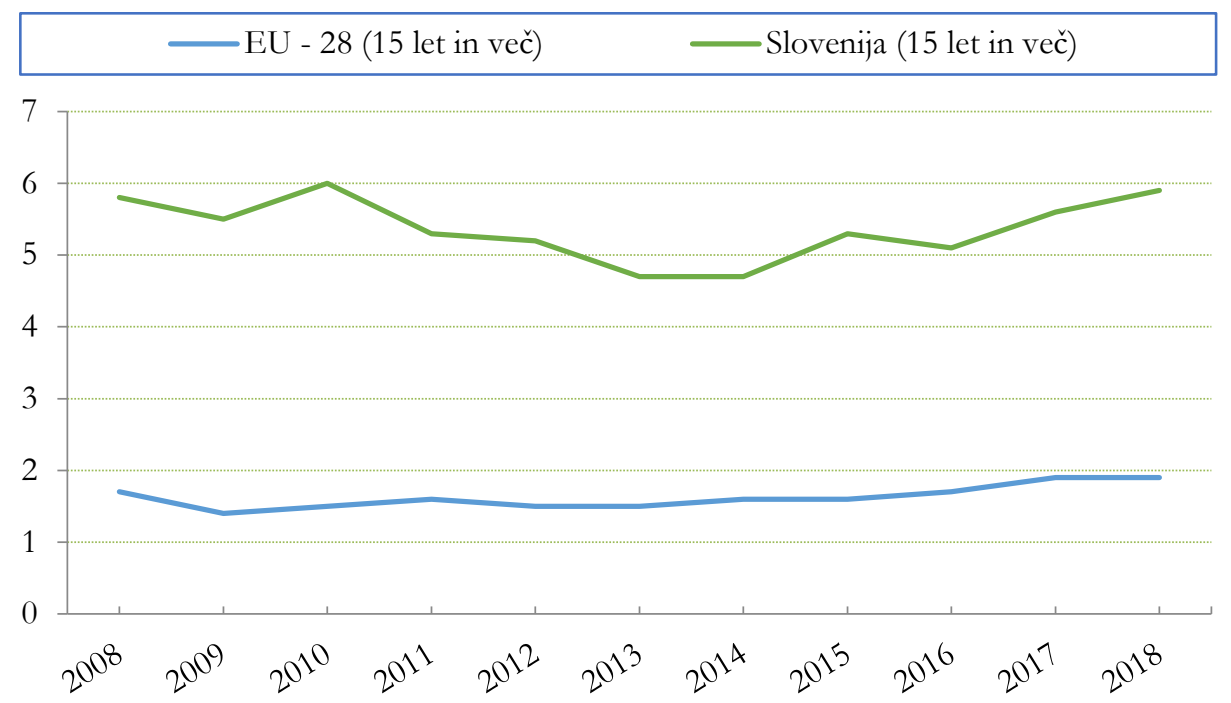

Slika 9: Deleži začasnih agencijskih delavcev med vsemi zaposlenimi v Sloveniji in v povprečju držav članic EU

(Eurostat, 2020j) 
Velik razkorak med začasnim agencijskim delom v Sloveniji in povprečjem držav članic EU nas je vodil še v pregled stanja agencijskega dela po državah članicah v letu 2018. S slike 10 je razvidno, da je Slovenija s kar 5,9\% deležem agencijskih delavcev med vsemi zaposlenimi na prvem mestu med članicami EU. Sledita Nizozemska s 4,2 \% in Španija s 3,9 \% deležem agencijskih delavcev. Poudariti pa je potrebno, da v Sloveniji zaradi velike razširjenosti študentskega dela med mladimi stanje ni povsem primerljivo.

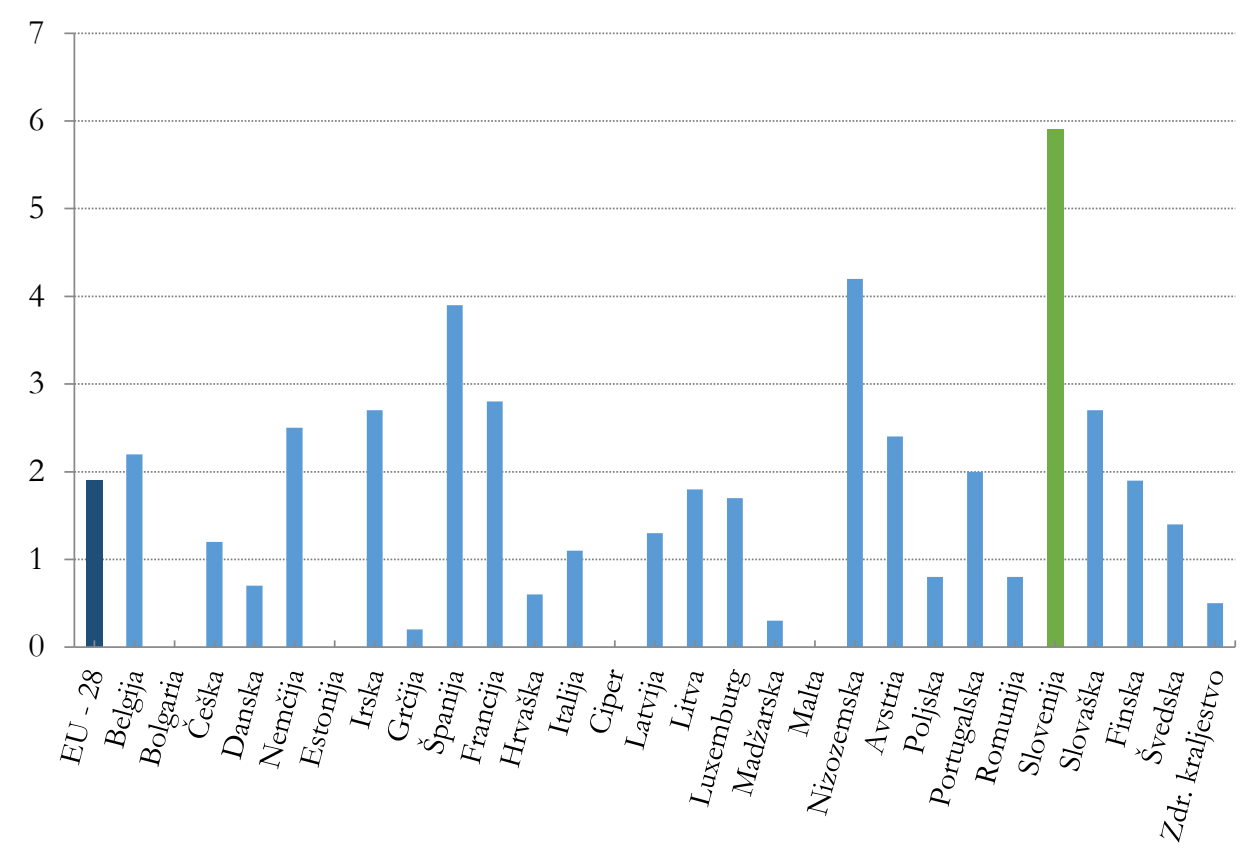

Slika 10: Delež začasnih agencijskih delavcev med vsemi zaposlenimi v Sloveniji in v članicah EU v letu 2018

(Eurostat, 2020j)

Podrobna analiza zaposlovanja preko zasebnih agencij (Redek, Bavdaž, Cepec, Domadenik, Godnov in Kostevc, 2017) kaže, da se v Sloveniji agencijsko delo med mladimi vse bolj pojavlja kot »institut poskusnega dela in prvega stika s podjetjem«. To je tudi ena izmed mnogih prednosti, ki jih zasebne agencije prinašajo na trg dela. Avtorji so $\mathrm{v}$ raziskavi podali prednosti in pomanjkljivosti zaposlovanja preko zasebnih agencij z različnih vidikov. Ugotovili so, da podjetjem agencijsko delo prinaša predvsem fleksibilnost in zmanjšuje administrativno delo, s čimer 
razbremenijo kadrovsko službo. Pomanjkljivost so opazili predvsem v nekaterih slabih praksah, ki so pogosto vezane na »kvazi« agencije. Po drugi strani agencijsko delo delavcem prinaša predvsem vrsto slabosti, povezanih s kvaliteto dela in vpliva na dolgoročni položaj posameznika. Kljub temu pa avtorji omenjajo tudi nekaj prednosti, npr. vzpostavitev kontakta s podjetji in povečanje možnosti za kasnejšo zaposlitev v podjetju. Na podlagi EU direktiv ni smiselno pričakovati, da se bo delež agencijskih delavcev zmanjšal. Zato avtorji predlagajo vzpostavitev dobrih praks agencijskega dela in izboljšanje problematičnih vidikov agencijskega dela, $\mathrm{k}$ čemur bi pripomogla dodatna primerjalna analiza agencijskega dela z vidika delavcev.

\section{$4 \quad$ Posledice prekarnosti}

Glede na dejstvo, da se večina zaposlenih v nestandardnih oblikah dela srečuje z negotovostjo in $\mathrm{s}$ tem povezano manjšo ekonomsko in socialno varnostjo $\mathrm{v}$ primerjavi s standardno obliko zaposlitve, nas posledice prekarnosti ne presenečajo. Najpogosteje se omenja slabo zdravje prekarnih delavcev, predvsem mentalno, ki je v povezavi s stalnim stresom, ki ga delavci doživljajo zaradi negotovosti, omejenega prostega časa in slabega socialnega in ekonomskega položaja.

Večina razmišlja, da je čas, ki ni opredeljen kot delovni, naš prosti čas, zato podajamo bolj natančno opredelitev časa. Dnevni čas je sestavljen iz delovnega časa in izven delovnega časa. Slednjega pa lahko razdelimo na čas, v katerem opravljamo posamezne obveznosti oz. nujna opravila, ter prosti čas. Medtem ko je prosti čas namenjen sproščanju, uživanju in počitku (npr. šport, druženje s prijatelji, potovanja - počitnice, poležavanje oz. lenarjenje), je čas, v katerem opravljamo posamezne obveznosti in nujna opravila, lahko neposredno povezan z zaposlitvijo (npr. pot v službo in iz službe, priprava ali izobraževanje za delo, iskanje zaposlitve), lahko pa le posredno (npr. gospodinjska dela, hišna opravila, nega in skrb za družinske člane). Zavedamo se dejstva, da je bila $\mathrm{v}$ industrijskem obdobju ločitev delovnega in prostega časa povsem logična. Danes pa se zaradi novih oblik in načinov opravljanja dela razlikuje tudi dojemanje prostega časa, kar je odvisno od avtonomnosti dela, ki ga ljudje opravljajo, od demografskih značilnosti, od kulturnih razlik ipd.

Standing (2018) omenja, da v globalnem tržnem sistemu čas doživi dve pomembni spremembi, in sicer $\mathrm{v}$ obravnavi samega časa in v vse manjšem spoštovanju 24-urne telesne ure. Če je industrijska družba delovala po časovnih blokih (10 ur v službi, 10 ur doma, ostalo v družbi), v dobi globalizacije opazimo skupek neformalnih norm. 
Statistika sicer pokaže, da posameznik v povprečju dela 8,2 ure/dan, vendar je potrebno upoštevati, da statistika ne beleži časa, ki ga posameznik opravi za službo izven delovnega časa. Drug problem so časovni pasovi, ki so naravno prilagojeni dnevni svetlobi. Telesni ritem človeka je v sozvočju z dnevno svetlobo in temo. Takrat ljudje potrebujemo spanec. Ker globalna ekonomija deluje kot stroj, saj je pomemben le profit, nima čuta do človeške fizionomije. Ljudje tako sredi noči vstanemo in opravljamo delo (komuniciramo s strankami, pogodbenimi partnerji, naročniki) z namenom, da nas ne bi izpodrinila konkurenca. Standing (2018) je to ponazoril z besedami: če je včasih veljal rek »rana ura, zlata ura«, danes velja »non stop ura« z namenom zagotavljanja konkurenčnosti.

Zato se nam zdi smiselna opredelitev po Parkerju (1971), ki prosti čas definira kot del dneva, v katerem so opravljene vse obveznosti in dolžnosti v sklopu delovnega časa, vse obveznosti, posredno povezane z zaposlitvijo, vse obveznosti, ki niso povezane $z$ zaposlitvijo, in vse obveznosti za zadovoljevanje fizioloških potreb. Prosti čas naj bo tako namenjen času, ki ga preživimo z aktivnostmi, ki nam nudijo užitek in sprostitev duha, saj je pomemben za regeneracijo telesa in pozitivno vpliva na naše zdravje in kvaliteto življenja.

Predvsem delavci v nestandardnih oblikah zaposlitve so stalno vpeti med delom (v smislu neposrednih in posrednih aktivnosti) ter prostim časom. Nezadostna ekonomska in socialna varnost jih prisili, da so s pomočjo sodobne tehnologije stalno dosegljivi in pripravljeni na nove naloge oz. posle, saj se bojijo, da jih bo sicer prehitela konkurenca, sami pa se bodo znašli v položaju, ki jim ne bo omogočal dostojnega življenja. Vse to pa vodi v prezaposlenost, posledice so utrujenost, stres, depresija in druga bolezenska stanja. Zato ne preseneča dejstvo, da po podatkih Evropske agencije za varnost in zdravje pri delu (ZVD, 2013) skoraj vsak četrti delavec trpi zaradi stresa, kar ni zanemarljivo, saj ta predstavlja 50 do 60 odstotkov vseh izgubljenih delovnih dni.

$\mathrm{V}$ zadnjem desetletju je zaznati vedno več novih oblik nestandardnega dela, saj digitalni mediji omogočajo različne možnosti opravljanja delovnih nalog in s tem drugačno poslovanje organizacij. Med njimi lahko omenimo vedno bolj uveljavljene platforme (npr. Google, Amazon, Airbn, Uber), ki delujejo kot priložnostni trgi dela. Značilnost delovanja platforme je uporaba digitalnih aplikacij, kar omogoča veliko fleksibilnost delavcev in prenos stroškov in kapitala na delo. Izvajanje storitev namreč poteka po sistemu »just in time«, podjetjem pa prinaša veliko fleksibilnost 
pri zaposlovanju. Srnicek (2017) podaja mnenje glede platform dela s strani delodajalca in delavca. Pravi, da podjetja z uporabo platform zmanjšajo stroške delovnega procesa na minimum, saj vodijo samo nadzor nad platformo in kujejo profite. Po drugi strani pa delavci od takega načina zaposlovanja nimajo nobenih koristi, saj je konkurenčnost med njimi velika, zato so pritiski hujši od dela v klasičnih tovarnah.

Namesto $\mathrm{z}$ dolgoročnimi delovnimi razmerji se srečujemo s kratkoročnimi nestandardnimi razmerji. Marvit (2014, v De Stefano, 2016, str. 4) pravi: »Pred internetom bi bilo res težko najti nekoga, ki bi ga zaposlili samo za 10 minut, nato pa bi ga odpustili. Toda z današnjo tehnologijo lahko posameznike najdete, jim plačate majhen znesek denarja in se jih znebite takoj, ko jih ne potrebujete več.» De Stefano (2016) resno tveganje vidi v dejstvu, da se delo dejansko »dobavlja« preko IT-kanalov. Ker so to spletne platforme ali aplikacije, ki ustrezajo povpraševanju in ponudbi fizičnih opravil, lahko »izkrivljajo« percepcijo podjetij oz. kupcev teh delavcev in znatno prispevajo $\mathrm{k}$ zaznani dehumanizaciji njihove dejavnosti. De Stefano zato pravi, da prakse dela preko platform ustvarjajo »človeka-storitev«, saj ga po uporabi zavržejo. Strinjamo se, da takšen način vodi v popolno razčlovečenje človeške družbe, zato bi morali o vseh novih načinih zaposlitve temeljito razmisliti.

Negativne posledice digitalizacije omenjajo tudi drugi avtorji. Colbertova, Yee in George (2016) so tako med delavci zaznali učinek »stalne povezanosti«, saj zaposleni ne ločijo več dela in prostega časa oz. zaposlitve in zasebnega življenja. Odkrili so, da se delavci v nestandardnih oblikah dela ne poistovetijo s sodelavci in organizacijo, saj so z drugimi sodelavci nepovezani. To jim daje občutek izoliranosti. Posamezniki imajo več težav pri navezovanju odnosov izven delovnega procesa, kar se lahko odraža tudi v družbi kot celoti.

Tassinarijeva in Maccarrone (2017) pa omenjata tudi širši vpliv digitalizacije na posameznika in družbo. Avtorja pravita, da digitalna tehnologija (digitalne aplikacije, platforme) omogoča discipliniranje delavcev in nadzor, ne da bi bilo potrebno delovni proces sploh organizirati. Delavci se sami ponotranjijo z disciplino delovnega procesa, so v stalni pripravljenosti in morajo biti odzivni, sicer jih lahko iz platforme celo izključijo. Ironija je, da bi bila taka praksa v standardnih razmerah povsem nesprejemljiva, s platformo pa postaja povsem normalna, sprejemljiva praksa. 
Veliko avtorjev omenja, da prekarno delo vpliva na zdravstveno stanje prekarnih delavcev in tudi širše. Julià, Vanroelen, Bosmans, Van Aerden in Benach (2017) tako povezujejo prekarno delo s slabim zdravjem in počutjem, še posebej s slabim duševnim zdravjem in tudi z majhnim zadovoljstvom na delu. Yoon, Choi, Jang, Lee in Park (2017) navajajo, da so prekarni delavci bolj depresivni, ko ostanejo brez zaposlitve. Menijo, da zaradi negativnih pričakovanj, da bi ponovno dobili zaposlitev. Ker veliko bolj trpijo zaradi izgube zaslužka, se jim mudi v ponovno zaposlitev, tako pa tudi trpi njihovo poklicno usposabljanje in imajo manjše možnosti za razvoj delovne kariere.

Burgardova, Brandova in House (2009) pa so ugotovili, da ima negotovost celo bolj negativen učinek na psihofizično zdravje kot izguba zaposlitve, predvsem zaradi stresa, kar ima tudi širše posledice. Han, Chang, Won, Lee, in Ham (2017) navajajo, da imajo delavci, ki so postali začasno zaposleni, večjo verjetnost, da bodo resno mislili na samomor, v primerjavi s tistimi, ki so zaposlitev za nedoločen čas obdržali. Nadalje ugotavljajo, da imajo prekarni delavci kljub delu s polnim delovnim časom več kot 2-krat večjo verjetnost, da bodo naredili samomor kot delavci, ki so v standardnem delovnem razmerju. Še bolj pa prekarnost prizadene delavce, ki so dobili zaposlitev za polovični delovni čas, saj je pri njih verjetnost za samomor celo 4-krat večja, kot če ne bi bili prekarni.

Burgardova, Kalousova in Seefeldtova (2012) poročajo, da delavci, ki dojemajo delo kot negotovo, več kot 2-krat pogosteje ocenjujejo, da je njihovo zdravje slabše, skoraj 4-krat pogosteje poročajo o napadih tesnobe ter 7-krat pogosteje o znakih depresivnosti. Maierjeva, MakWana in Hare (2011) pa ugotavljajo, da neprestan stres znižuje raven samokontrole, zato je več deviantnega vedenja.

Bilban (2018) opozarja, da kronični stres dokazano vpliva na nastanek metabolnega sidroma in debelosti. Poleg slabšega mentalnega zdravja prekarnih delavcev omenja tudi povezanost med začasnim delom in bolečinami $v$ mišicah in križu. Nadalje ugotavlja, da negotovost na delovnem mestu vpliva na nastanek koronarne bolezni, arterijske hipertenzije in povečuje tveganje za ishemijo srca. Podobno opisuje tudi Dodič Fikfakova (v Poglajen, 2017), ki pravi, da pridejo somatske bolezni, ki jih sicer poznamo v vseh oblikah dela, pri prekarnih oblikah še bolj do izraza. Stres, ki ga negotovost povzroča, tako simptome bolezni, ki jo posameznik ima, samo še intenzivira. 
Izsledki raziskave v okviru projekta Skupaj za zdravje na Nacionalnem inštitutu za javno zdravje v Sloveniji kažejo, da so prekarni delavci med najbolj ranljivim prebivalstvom v Sloveniji. Njihovo življenje poteka v negotovosti, saj so za prekarne oblike zaposlitve značilne: nizka stopnja varnosti zaposlitve in manjše ali sploh nezagotovljene delovne in socialne pravice delavcev, kar se kaže $\mathrm{v}$ negativnih učinkih na zdravje prekarnih delavcev. Bilban (2018) pravi, da številne zdravstvene težave prekarnih delavcev izvirajo iz negotovega zaposlitvenega statusa, poleg tega pa so tudi posledica tega, da so ti prebivalci marginalizirani $\mathrm{v}$ zdravstvenem sistemu. Obstoječa ureditev zdravstvenega zavarovanja jim namreč ne zagotavlja učinkovitega dostopa do zdravstvenega zavarovanja in zdravstvenih ustanov. Zaradi negotovega ali nizkega finančnega stanja mnogi strošek zdravstvenega zavarovanja težko plačajo, saj so poleg negotovega dela odvisni tudi od plačilne discipline delodajalcev. Slabše zdravstveno stanje je velikokrat tudi posledica dejstva, da si bolniške odsotnosti ne morejo privoščiti, saj imajo pri nekaterih oblikah prekarnega dela ovirano pravico do bolniškega staleža.

Omeniti je potrebno še naraščanje revščine, ki jo kot posledico prekarnosti omenjajo mnogi avtorji (npr. Goerne, 2011; Halleröd, Ekbrand in Bengtsson 2015; Bilban, 2018). Ker se odgovornost, tveganja in stroški prenašajo na delavce, se opazi vpliv na življenje teh delavcev. Ker se tveganje za revščino in socialno neenakost krepi, je večanje neenakosti v družbi med bolj problematičnimi. Koncentriranje dohodka na eni strani pomeni tudi krepitev moči in verjetnost, da politika ravna $\mathrm{v}$ korist močnejših, je večja. Zaradi naraščajoče neenakosti je veliko iracionalnih odločitev med ljudmi, ki se trudijo, da jih družbena sredina ne bi izločila. Tak primer je npr. najem kredita kljub kreditni nesposobnosti. Posledice se kažejo tako, da ljudje izgubljajo zaupanje v družbenoekonomski sistem, kar vodi do socialnih in političnih trenj, zaznati je naraščanje ekstremizma.

\section{$5 \quad$ Diskusija in zaključki}

$\mathrm{V}$ današnji družbi tehnološki razvoj, gospodarska rast in globalizacija v največji meri ustvarjajo pritisk na delodajalce, da razmislijo o načinih zaposlovanja, s katerimi bodo lahko $\mathrm{v}$ globalnem okolju ostali konkurenčni tudi $\mathrm{v}$ prihodnosti. Val digitalizacije (hitri mobilni internet, sistemi samostojnega učenja, analiza podatkov, robotika in avtomatizacija, robotski procesi ter vedno bolj razširjena virtualna resničnost) ima vedno večji vpliv tudi na družbo, kar se kaže v spreminjanju delovnih mest in delovnih pogojev ter v spremenjenem načinu življenja. Celovite razsežnosti 
digitalizacije bomo v večji meri zaznali v naslednjih letih, že zdaj pa opazimo vrsto novih oblik dela, ki jih za nemoteno poslovanje zahteva sodobna organizacija.

V digitalni dobi je omenjanje tveganja, negotovosti oz. prekarnosti v povezavi z zaposlovanjem postalo povsem običajno in pričakovano, saj negotovost zasledimo tudi v standardni obliki delovnega razmerja - zaposlitvi za nedoločen čas s polnim delovnim časom. Mnogim namreč plača ne omogoča dostojnega življenja, živijo pod pragom revščine ali pa delajo $\mathrm{v}$ slabih delovnih razmerah in včasih celo zakonsko prepovedanih pogojih dela. Kljub temu pa raziskave kažejo, da standardna oblika dela $v$ primerjavi $z$ nestandardnimi oblikami zaposlitve še vedno zagotavlja večjo varnost delavcev in več socialnih in ekonomskih pravic. Na evropskem trgu dela je $\mathrm{v}$ zadnjem desetletju zaznati porast nestandardnih oblik dela, zato so oblikovalci politik in institucij (ILO, 2015) začeli zagovarjati reforme na trgu dela, z namenom zmanjšati regulativno vrzel med delavci $\mathrm{v}$ standardnih in nestandardnih oblikah zaposlovanja. Večina avtorjev slabši položaj delavcev, zaposlenih $\mathrm{v}$ nestandardnih oblikah, vidi v negotovosti in neenakosti, nižjem plačilu, daljšem delovnem času, tehnološkem nadzoru nad delavci, nezmožnosti napredovanja, slabšem kariernem razvoju posameznika, večjem stresu in negativnem vplivu na zdravje.

Nasprotno pa nestandardne oblike dela podjetjem prinašajo vrsto prednosti, npr. manjši stroški dela, lažje najemanje in odpuščanje delavcev ter manj različnih vrst tveganj, ki sicer nastopajo v primeru standardnega delovnega razmerja. Prihranek pri stroških dela se pokaže predvsem v obliki sodelovanja s posamezniki, ko razmerje med delodajalcem in delavcem regulira civilno pravo, saj se delodajalci znebijo plačila prispevkov, nadur, bolniških nadomestil ipd. Tako je $\mathrm{v}$ primeru najetega samozaposlenega podjetnika le-ta po izdaji računa v negotovem položaju in odvisen od plačila podjetja, podjetje pa v mnogo boljšem položaju, ima nižje stroške, saj plača storitev, s tem pa odpadejo prispevki $v$ povezavi s plačo zaposlenega.

Čeprav večina avtorjev omenja prevladujoč negativni učinek nestandardnih oblik dela za delavce, od tod tudi negotovost in prekarnost, je potrebno omeniti, da ni vsako nestandardno delo prekarno. Še posebej, če si delavci tako obliko izberejo prostovoljno, ker jim tako ustreza, npr. zaposlitev s krajšim delovnim časom za lažje usklajevanje družinskega in poklicnega življenja, nabiranje delovnih izkušenj ipd. 
Razmere na trgu dela kažejo, da je delež nestandardnih oblik dela med vsemi delovno aktivnimi v Sloveniji višji od $30 \%$, med mladimi v starostni skupini od 15 do 24 let pa celo višji kot $70 \%$. Tako visok odstotek nestandardnih oblik dela nas je vodil v bolj podrobno proučevanje razmer. Najprej smo proučili delež zaposlenih za nedoločen čas glede na vse delovno aktivne v Sloveniji in povprečje držav članic EU. Razkorak med povprečjem držav članic EU $(72,8 \%)$ in Slovenijo $(71,3 \%)$ ni velik, drugačno sliko pa kažejo rezultati mladih v starostni skupini od 15 do 24 let. Med delovno aktivnimi mladimi v Sloveniji je samo 30,3 \% zaposlenih za nedoločen čas, v povprečju držav članic EU 53,8 \%. Med posameznimi članicami je Slovenija celo na predzadnjem mestu, zaostaja le Španija, ki ima 27,1 \% delovno aktivnih mladih zaposlenih za nedoločen čas.

Bolj podroben pregled vrste zaposlitve med delovno aktivno mladino v Sloveniji pokaže, da je najpogostejša vrsta zaposlitve od leta 2008 do 2018 študentsko delo. V letu 2018 je ta delež 39,5 \%, sledi delež redne zaposlitve mladih za nedoločen čas (30,3\%). V redni zaposlitvi za določen čas je 20,5\% delovno aktivne mladine, 7,2 $\%$ jih opravlja delo v drugih oblikah dela ali kot pomagajoči družinski člani, najmanj pa je samozaposlenih (2,5\%). Primerjava z letom 2008 pokaže, da se je zaposlenost najbolj povečala $\mathrm{v}$ korist zaposlitve za nedoločen čas in študentskega dela (pri obeh za 2,7 odstotnih točk), sledi samozaposlitev, ki se je povečala za 0,4 odstotnih točk. Pri drugih oblikah zaposlitve je v primerjavi z letom 2008 zaznati upad, in sicer pri deležu redne zaposlitve za določen čas za 5 odstotnih točk, pri opravljanju dela v drugih oblikah ali kot pomagajoči družinski član pa za 0,8 odstotnih točk. Visok delež skupnih nestandardnih oblik dela oz. nizek delež zaposlitev za nedoločen čas med vsemi delovno aktivnimi mladimi v Sloveniji lahko razlagamo z možnostjo opravljanja študentskega dela, ki je v obliki, kot jo pozna Slovenija, v drugih državah EU ne poznajo.

Prav zaradi študentskega dela ne preseneča velik razkorak primerjave začasne zaposlitve mladih v Sloveniji in povprečjem držav članic EU. V starostni skupini od 15 do 24 let je delež začasno zaposlenih v Sloveniji $67 \%$, manj v povprečju držav članic EU (43,5\%). V skupini od 25 do 29 let pa je takih zaposlitev v Sloveniji 31 $\%$, v povprečju držav članic EU pa 22,5\%. V tej starostni skupini je v Sloveniji manj študentskega dela, saj velja omejitev opravljanja študentskega dela do 26. leta, z nekaterimi izjemami. Čeprav se zdi tako visok delež začasnih zaposlitev med mladimi zaskrbljujoč, pa se nam razlog, zakaj so mladi sprejeli tak način zaposlitve, zdi bolj optimističen. V Sloveniji si namreč kar $74 \%$ mladih med 15. in 24. letom stalne 
zaposlitve sploh ni želelo (v povprečju držav članic EU le 16,6 \%), medtem ko je 16,5 \% takih, ki redne zaposlitve niso mogli dobiti (v povprečju držav članic EU 29,8 \%). Podobna je slika pri zaposlitvi s krajšim delovnim časom - v Sloveniji je kar 80 $\%$ mladih tako zaposlenih, ker se izobražujejo.

Študentsko delo torej lahko prinese vrsto prednosti, saj si z njim mladi v času študija pridobijo prve delovne izkušnje, s tem pa boljše pogoje pri iskanju zaposlitve. Pomembno je, da študenti opravljajo delo v panogah, za katere se izobražujejo, saj delovne izkušnje med študijem, še posebno tiste, povezane z vsebino študijskega programa, vplivajo na krajši čas iskanja in na ustreznost zaposlitve po diplomi. Podatki raziskave Eurostudent kažejo, da je med študenti zaslediti več kot $50 \%$ povezav med delovnimi izkušnjami in področjem študija le v Estoniji, na Finskem, v Latviji, na Norveškem, v Romuniji in na Švedskem (Hauschildt, Gwosć, Netz in Mishra, 2015). V Sloveniji si večina študentov delovne izkušnje pred prvo zaposlitvijo pridobiva s študentskim delom, ki sodi v skupino atipičnih zaposlitev (Kosi, Nastav in Šušteršič, 2010), njihove delovne izkušnje pa večinoma niso povezane $z$ vsebino (področjem) študija. Kljub temu pa tudi teh izkušenj ne smemo zanemariti, saj so Souto-Otero, Ulicna, Schaepkens in Bognar (2012) dokazali, da je med kompetencami, ki jih delodajalci iščejo, velik del mehkih veščin: komunikacijske sposobnosti, sposobnost dela v skupini, fleksibilnost, samozavestnost idr. Tako lahko mladim tudi študentsko delo, ki ni direktno povezano s smerjo študija, prinese prednost pri iskanju zaposlitve, saj študenti poleg pridobivanja mehkih veščin spoznavajo realnost trga dela, spoznavajo delodajalce in sklepajo pomembna poznanstva za iskanje zaposlitve po zaključku študija.

Podatki zaposlenosti mladih (Eurostat, 2020d; Eurostat, 2020g) kažejo, da je pri zaposlovanju za določen čas in pri zaposlovanju s skrajšanimi oblikami zaposlitve Slovenija v vrhu EU. Po Ignjatoviću in Trbančevi (2009) bi morali biti obe obliki odskočna deska za prehod mladih $\mathrm{v}$ redno zaposlitev, vendar velikokrat vodita $\mathrm{v}$ brezposelnost. Zato lahko rečemo, da pri mladih narašča individualno tveganje, saj delne in negotove zaposlitve posameznikom ne zagotavljajo materialne in socialne varnosti. Ker take oblike dela ne zagotavljajo neodvisnosti, saj trajajo le kratek čas (Ule in Živoder, 2012), se mladi ne osamosvojijo, ampak podaljšujejo bivanje pri starših, kar je opazen trend v vseh sredozemskih državah (Klanjšek, 2013). 
Prekarstvo je torej še posebej kritično za mlade, ki se lahko znajdejo v nezavidljivi situaciji, kar vodi do odlaganja osamosvojitve, ustvarjanja družine ipd. Po drugi strani pa so mladi najbolj dovzetni za vse novosti, ki jih prinaša digitalizacija, tudi do novih oblika dela. Mnoge so celo dobro plačane in se posamezniki za njih odločajo prostovoljno - ker jim tako ustreza.

Ko govorimo o prekarnosti, je treba razlikovati med subjektivno in objektivno prekarnostjo. Objektivna je vezana na obliko dela oz. pogodbeno razmerje. Glede na dejstvo, da je glede negotovosti izvzeta samo standardna oblika zaposlitve za nedoločen čas s polnim delovnim časom, vse druge oblike dela (nekateri jih imenujejo nestandardne, drugi atipične) sodijo $\mathrm{v}$ skupino, $\mathrm{v}$ kateri najdemo negotovost, torej so prekarne.

Drugače je s subjektivno prekarnostjo, saj temelji na doživljanju delavca glede negotovosti in izkušenj z delom. Delavce nestandardnih oblik dela tako lahko razdelimo v tri glavne skupine:

- Prvo skupino predstavljajo tisti, ki so nestandardno zaposlitev prisiljeni sprejeti. To so pogosto mladi, ki po končanem izobraževanju ne najdejo zaposlitve. S priložnostnim oz. prekarnim delom pa se pojavi problem pozne osamosvojitve, saj pogosto podaljšujejo bivanje pri starših. To jih ovira pri ustvarjanju družine in poznem materinstvu. V skupino tistih, ki so nestandardno obliko zaposlitve prisiljeni sprejeti, lahko štejemo tudi brezposelne. Njim nestandardna zaposlitev predstavlja najboljšo ali celo edino možnost, da se vključijo $\mathrm{v}$ delovno okolje z optimizmom na bolj svetlo prihodnost. Potrebno je omeniti še vse tiste, ki jih prav delovno okolje "prisili« $\mathrm{v}$ prehod iz rednega delovnega razmerja $\mathrm{v}$ nestandardno zaposlitev. Za vse, ki so tako rekoč "prisiljeni« sprejeti nestandardno zaposlitev, le-ta predstavlja po eni strani edino možnost preživetja oz. zagotavljanja finančnih sredstev za osnovne potrebe, po drugi strani pa negativno vpliva na posameznika in družbo.

- Drugo skupino delavcev predstavljajo tisti, ki se zavestno odločijo, da jih bo njihova poklicna pot namesto rednega delovnega razmerja za nedoločen čas vodila v oblike dela, ki so jim ljubše oz. vidijo možnosti, da $v$ njih uresničijo svojo vizijo. To so pogosto ljudje, ki razmišljajo o problemih, stanju in izzivih, zbirajo ideje za reševanje težav ter so sposobni najti inovativne 
rešitve. Zato nestandardno zaposlitev doživljajo kot najboljšo možnost, da lahko svoj potencial izkoristijo $\mathrm{v}$ ustvarjalnem in inovativnem delu, $\mathrm{v}$ vodenju drugačnih oblik sodelovanja in medsebojnega povezovanja.

- V tretji skupini pa vidimo tiste, ki so dobro situirani in jim materialne dobrine ne predstavljajo nobenega izziva, saj se jim kopičenje bogastva ne zdi prav nič vznemirljivo. Izziv jim lahko predstavljajo posamezne aktivnosti, ki jih opravljajo $\mathrm{v}$ nestandardnih oblikah dela. Tako se osebnostno razvijajo, po drugi strani pa so družbeno koristni.

Ko govorimo o prekarnih delavcih, jih vidimo v prvi skupini nestandardnih oblik dela. Menimo, da zavestna prostovoljna odločitev posameznika za opravljanje nestandardnih oblik dela kljub možnosti vključitve $\mathrm{v}$ redno delovno razmerje ne more biti razlog, da bi omenjeno skupino poimenovali prekarni delavci. Strinjamo pa se z dejstvom, da bi morale vse nestandardne oblike dela posamezniku nuditi enake socialne in ekonomske pravice kot standardna zaposlitev. Nestandardne oblike dela namreč pogosto prikrivajo izkoriščanje delavcev, dolge delovnike, neplačano delo in nezmožnost usklajevanja poklicnega in družinskega življenja.

Posledice prekarnosti vplivajo na posameznika, gospodarstvo in na celotno družbo. Med najpogostejšimi posledicami negotove zaposlitve je omenjen stres, ki ga povzroča negotovost zaposlitve in z njo povezane težave, npr. nestalnost dohodka, nižje plačilo, manjše možnosti za razvoj kariere ter kolektivno povezovanje, manjše delavske in socialne pravice. Pogosto omenjena stanja vodijo v kriminal, brezup, samomor in dohodkovno neenakost. Kanjuo Mrčela in Ignjatović (2015) omenjata, da ima prekarnost $\mathrm{v}$ primerjavi s prožnostjo »le negativno konotacijo, in sicer označuje razmere dela in zaposlovanja, ki imajo za posameznike samo negativne posledice«. Prekaren način dela tako ustreza le delodajalcu, saj gre za najcenejši način, ki se izvaja po navodilih in volji delodajalca. Zato je širjenje prekarnih oblik razumljivo, saj je cilj podjetij čim večji profit, državi pa je $\mathrm{v}$ interesu, da je gospodarska rast čim večja.

Premalo se zavedamo, da s sprejemanjem in toleriranjem prekarnega dela škodujemo družbi kot celoti. Zaradi globalizacije, digitalizacije in konkurenčnosti ne moremo pričakovati, da bo povpraševanje po fleksibilnih oblikah dela upadlo. Celo nasprotno, skoraj nemogoče je, da bi se vrnili v čas standardne oblike dela in s tem povezane stabilnosti in socialne varnosti, saj si težko predstavljamo delovni proces, 
ki bi temeljil samo na podlagi fiksnih delovnih mest in s fiksnim delovnim časom. Da bi sledili spremembam, organizacije v večji meri uporabljajo neobičajne delovne prakse, skrbijo za prožnosti, okretnosti in ustrezne organizacijske procese ter zmanjšujejo stroške. Povezanosti med nestandardnimi oblikami dela in prekarnostjo pa ne moremo zanikati. Zato je treba v večji meri razmišljati o sistemskih ukrepih glede prekarnega dela, saj s stališča države negativne posledice prekarnosti nikakor ne predstavljajo zanemarljivih stroškov.

\section{Literatura}

Bilban, M. (2018). Prekarno delo. Delo in varnost. 63(6), 33-34.

Bobek, A., Pembroke, S. \& Wickham, J. (2018). Living with Uncertainty: The Social Implications of Precarious Work, Brussels: Foundation for European Progressive Studies.

Broughton, A., Green, M., Rickard, C., Swift, S., Eichhorst, W., Tobsch, V., ... Tros, F. (2016). Precarious Employment in Europe. (Employment and Social Affairs). Brussels: European Parliament. Directorate-General for Internal Policies. Policy Department A: Economic and Scientific Policy.

Burgard, S. A., Brand, J. E., \& House, J. S. (2009). Perceived job insecurity and worker health in the United States. Social Science \& Medicine, 69(5), 777-785. DOI: 10.1016/j.socscimed.2009.06.029.

Burgard, S. A., Kalousova, L. \& Seefeldt, K.S. (2012). Perceived Job Insecurity and Health: The Michigan Recession and Recovery Study. Journal of occupational and environmental medicine / American College of Occupational and Environmental Medicine, 54(9), 1101-1106. DOI: 10.1097/JOM.0b013e3182677dad.

De Stefano, V. (2016). The rise of the "just-in-time workforce": on-demand work, crowdwork and labour protection in the "gig-economy". Conditions of work and employment series, No. 71. Geneva: ILO. Pridobljeno 29. 2. 2020 na https://www.ilo.org/wcmsp5/groups/public/--ed_protect/---protrav/---travail/documents/publication/wcms_443267.pdf.

Cranford, C. J., Vosko, L. F. \& Zukewich, N. (2003). Precarious employment in the Canadian labour market: A statistical portrait. Just Labour, 3(Fall), 6-22. DOI: 10.25071/1705-1436.164.

Colbert, A., Yee, N. \& George, G. (2016). The Digital Workforce and the Workplace of the Future. Academy of Management Journal, 59(3), 731-739. DOI: 10.5465/amj.2016.4003.

Dobrovoljc, H. in Snoj, M. (2016). Kaj je prav »prekaren« ali »prekeren«? Jezikovna svetovalnica. Pridobljeno 28. 1. 2020 na https://svetovalnica.zrc-sazu.si/topic/1288/kaj-je-prav-prekarenali-prekeren.

Eurostat, (2020a). Employees by type of employment contract, age and European socio-economic $\begin{array}{llllll}\text { group } \quad \text { [lfsa_esegt]. } & \text { Pridobljeno } & 22 . & 2 . & 2020 & \text { na }\end{array}$ https:/ /appsso.eurostat.ec.europa.eu/nui/show.do?dataset=lfsa_esegt\&lang=en.

Eurostat, (2020b). Employment by sex, age and citizenship [lfsa_egan]. Pridobljeno 22. 2. 2020 na https://appsso.eurostat.ec.europa.eu/nui/show.do?dataset=lfsa_egan\&lang=en.

Eurostat, (2020c). Self-employment by sex, age and citizenship (1 000) [lfsa_esgan]. Pridobljeno 22. 2. 2020 na https://appsso.eurostat.ec.europa.eu/nui/show.do?dataset=lfsa_esgan\&lang=en.

Eurostat, (2020d). Young temporary employees as percentage of the total number of employees [yth_empl_050]. $\quad$ Pridobljeno $\quad 22 . \quad 2 . \quad 2020 \quad$ na https://appsso.eurostat.ec.europa.eu/nui/show.do?dataset=yth_empl_050\&lang=en.

Eurostat, (2020e). Temporary employees by sex, age and economic activity [lfsa_etgan2]. Pridobljeno 22.

https:/ / appsso.eurostat.ec.europa.eu/nui/show.do?dataset=lfsa_eegan2\&lang=en. 
Eurostat, (2020f). Temporary employees by sex, age and main reason [lfsa_etgar]. Pridobljeno 22. 2. 2020 na https://appsso.eurostat.ec.europa.eu/nui/show.do?dataset=lfsa_etgar\&lang=en.

Eurostat, (2020g). Part-time employment as percentage of the total employment, by sex and age (\%) [lfsa_eppga]. $\quad$ Pridobljeno $\quad 22 . \quad 2.2020$ na https:// appsso.eurostat.ec.europa.eu/nui/show.do?dataset=lfsa_eppga\&lang=en.

Eurostat, (2020h). Part-time employment as percentage of the total employment for young people [yth_empl_060]. $\quad$ Pridobljeno $22 . \quad 2 . \quad 2020$ na https://appsso.eurostat.ec.europa.eu/nui/show.do?dataset=yth_empl_060\&lang=en.

Eurostat, (2020i). Main reason for part-time employment - Distributions by sex and age (\%) [lfsa_epgar]. $\quad$ Pridobljeno $22 . \quad 2.2020$ na https:// appsso.eurostat.ec.europa.eu/nui/show.do?dataset=lfsa_epgar\&lang=en.

Eurostat, (2020j). Temporary employment agency workers by sex, age and NACE Rev. 2 activity [lfsa_qoe_4a6r2]. $\quad$ Pridobljeno $22 . \quad 2.2020$ na https:/ /appsso.eurostat.ec.europa.eu/nui/show.do?dataset=lfsa_qoe_4a6r2\&lang=en.

Eurostat, (2020k). Precarious employment by sex, age and NACE Rev. 2 activity [lfsa_qoe_4ax1r2] $\begin{array}{llll}\text { Pridobljeno } & 22 . & 2 . & 2020 \\ \end{array}$ https://appsso.eurostat.ec.europa.eu/nui/show.do?dataset=lfsa_qoe_4ax1r2\&lang=en.

Goerne, A. (2011). A Comparative Analysis of In-Work Poverty in the European Union. V Fraser, N., Gutiérrez, R. in Peña-Casas, R. (Eds.), Working Poverty in Europe: A comparative approach (15-45). Basingstoke, Palgrave Macmillan.

Halleröd, B., Ekbrand, H. \& Bengtsson, M. (2015). In-work poverty and labour market trajectories: Poverty risks among the working population in 22 European countries. Journal of European Social Policy, 25(5), 473-488. DOI: 10.1177/0958928715608794.

Han, K. M., Chang, J., Won, E., Lee, M. S. \& Ham, B. J. (2017). Precarious employment associated with depressive symptoms and suicidal ideation in adult wage workers. Journal of Affective Disorders, 218, 201-209. DOI: 10.1016/j.jad.2017.04.049.

Hauschildt, K., Gwosć, C., Netz, N. \& Mishra, S. (2015). Social and Economic Conditions of Student Life in Europe: Synopsis of Indicators EUROSTUDENT V 2012-2015. DOI: 10.3278/6001920bw.

Helfen, M. (2015). Institutionalizing Precariousness? The Politics of Boundary Work in Legalizing Agency Work in Germany, 1949-2004, Organization Studies, Vol. 36, no. 10, pp. 1-36. DOI: $10.1177 / 0170840615585338$.

Ignjatović, M. \& Trbanc, M. (2009). Zaposlovanje in brezposelnost mladih: aktivni, fleksibilni in prilagodljivi V T. Rakar in U. Boljka (eds.), Med otroštvom in odraslostjo: analiza položaja mladih v Sloveniji 2009. str. 39-56. Ljubljana: Ministrstvo za šolstvo in šport - Urad za mladino in Inštitut RS za socialno varstvo.

ILO, (2015). Non-standard forms of employment. Report for discussion at the Meeting of Experts on Non-Standard Forms of Employment (Geneva, 16-19 February 2015). Geneva: International Labour Office, Conditions of Work and Equality Department. Pridobljeno 12. 11. 2016 na http://www.ilo.org/wcmsp5/groups/public/---ed_protect/---protrav/--travail/documents/meetingdocument/wcms_336934.pdf .

Julià, M., Vanroelen, C., Bosmans, K., Van Aerden K. \& Benach, J. (2017). Precarious Employment and Quality of Employment in Relation to Health and Well-being in Europe. International Journal of Health Services, 47(3), 389-409. DOI: 10.1177/0020731417707491.

Kanjuo Mrčela, A. \& Ignjatović, I. (2015). Od prožnosti do prekarnosti dela: stopnjevanje negativnih sprememb na začetku 21. Stoletja. Teorija in praksa, 52(3), 350-381.

Katz, L. F. \& Krueger, A. B. (2019). The Rise and Nature of Alternative Work Arrangements in the United States, 1995-2015. ILR Review, 72(2), 382-416. DOI: 10.1177/0019793918820008.

Keller, B. \& Seifert, H. (2013). Atypical employment in Germany: Forms, development, Patterns. Transfer: European Review of Labour and Research, 19(4), 457-474. DOI: 10.1177/1024258913501757.

Klanjšek, R. (2013). Living Conditions and Socioeconomic Situation of vouth. Pridobljeno 10.5.2016 na http://projects.ff.uni-mb.si/ cepso/web/wp-content/uploads/2014/01/ExecutiveSummary-of-results-of-Slovenian-Youth-2013-study1.pdf. 
Kosi, T., Nastav, B. in Šušteršič, J. (2010). Pomen študentskega dela z vidika trga dela in uspešnosti. IB Revija, 44(3-4), 65-80.

International Labour Organization, (2016). Non-standard employment around the world. Geneve: International Labour Office. Pridobljeno 10.2020 na https://www.ilo.org/wcmsp5/groups/public/---dgreports/---dcomm/--publ/documents/publication/wcms_534326.pdf.

Inštitut za slovenski jezik Frana Ramovša ZRC SAZU (2014). Slovar slovenskega knjižnega jezika, druga, dopolnjena izdaja. Pridobljeno 28. 1. 2020 na https: / / fran.si/iskanje?View=1\&Query=prekaren\&hs=1.

Maier, S. U., Makwana, A. B. \& Hare, T. A. (2015). Acute Stress Impairs Self-Control in Goal-Directed Choice by Altering Multiple Functional Connections within the Brain's Decision Circuits. Nevron, 87(3), 621-631. DOI: 10.1016/j.neuron.2015.07.005.

McKay, S., Jefferys, S., Paraskevopoulou, A. \& Keles, J. (2012). Study on precarious work and social rights. Working Lives Research Institute. Carried out for the European Commission (VT/2010/084).

Medveš, Z. \& Muršak, J. (2010). Prehodnost v izobraževalnem sistemu - vprašanje sistemske tehnike ali družbene strategije? Sodobna pedagogika, 2(61), 6-13. Pridobljeno 3. 3. 2020 na https://www.sodobna-pedagogika.net/clanki/02-2010_prehodnost-v-izobrazevalnemsistemu-vprasanje-sistemske-tehnike-ali-druzbene-strategije-uvodnik/.

Moody, K. (2016). U.S. Labor: What's New, What's Not? Solidarity, 1.maj. Pridobljeno 29. 2. 2020 na https://solidarity-us.org/us_labor_new_and_not/.

Olsthoorn, M. (2014). Measuring Precarious Employment: A Proposal for Two Indicators of Precarious Employment Based on Set-Theory and Tested with Dutch Labor Market-Data. Social Indicators Research, 119(1), pp. 421-441, Springer.

Parker, S. (1971). The Future of Work and Leisure. London: MacGibbon and Kee

Poglajen, Č. (2017). Skozi oči prekariata: brez konsenza. Ljubljana: samozaložba.

Poglajen, Č. (2018). Skozi oči prekariata: čas za konkretne ukrepe. Ljubljana: Inštitut za študije prekariata.

Redek, T., Bavdaž, M., Cepec, J., Domadenik, P., Godnov, U. in Kostevc, Č. (2017). Vpliv zasebnih agencij za zaposlovanje na trg dela v Sloveniji: Poročilo. Ljubljana: Zavod Republike Slovenije za zaposlovanje. $\quad$ Pridobljeno $25 . \quad 2.2020$ na https://www.ess.gov.si/_files/10742/Vpliv_zasebnih_agencij_za_zaposlovanje_na_trg_dela _v_Sloveniji.pdf.

Sindikat Mladi plus (2017). Prekarne? oblike dela. Pridobljeno 2. 2. 2020 na https://www.mladiplus.si/wp-content/uploads/2018/10/PREKARNE-oblike-delaweb.pdf.

Souto-Otero, M., Ulicna, D., Schaepkens, L. \& Bognar, V. (2012). Study on the impact of Non-Formal Education in youth organisations on young people's employability. Pridobljeno 14. 4. 2017 na http://euroscoutinfo.com/wp-content/uploads/2012/10/ReportNFE_PRINT.pdf.

Srnicek, N. (2017). The challenges of platform capitalism: Understanding the logic of a new business model. Juncture, 23(4), 254-257. DOI:10.1111/newe.12023.

Standing, G. (2018). Prekariat: nevarni novi razred. Ljubljana: Založba Krtina.

SURS, (2019). Zaposleni glede na vrsto delovnega razmerja. Pridobljeno 22.2.2020 na https://pxweb.stat.si/SiStatDb/pxweb/sl/10_Dem_soc/10_Dem_soc_07_trg_dela_02_0 7008_akt_preb_po_anketi_02_07621_akt_preb_ADS_letno/0762108S.px/.

Svedaite, E. \& Tamosiunas, T. (2013). Investigation of the Advantages and Disadvantages of Temporary Employment, Socialiniai tyrimai / Social Research, Vol. 1, no. 30, pp. 64-70.

Tassinari, A. \& Maccarrone, V. (2017). The mobilisation of gig economy couriers in Italy. Transfer: European Review of Labour and Research, 23(3), 353-357. DOI:10.1177/1024258917713846.

Vertot, N. (2009). Mladi v Sloveniji. Ljubljana: Statistični urad Republike Slovenije.

Vosko, L. (2010). Managing the Margins: Gender, Citizenship, and the International Regulation of Precarious Employment. Oxford: Oxford University Press. 
Yoon, H. J., Choi, J. W., Jang, S. Y., Lee, S. A., \& Park, E. C. (2017). The effect of job loss on depressive symptoms: The results from the Korean Welfare Panel Study (2007-2013). International Journal of Social Psychiatry, 63(1), 57-62. DOI: 10.1177/0020764016681590

ZVD. (2013). Stres na delovnem mestu (v EU in Sloveniji). Delo in varnost, LVIII(2), 34-37. Pridobljeno 3. 2. 2018 na http://www.zvd.si/media/medialibrary/2014/05/RDV_2013_02_05_Stres_na_delovnem_ mestu.pdf. 


\title{
SPREMEMBE IN TRANZICIJE V ČASU KRIZE TER VLOGA VODSTVA PRI TEM
}

\author{
EVA JEREB IN MARKO URH \\ Univerza v Mariboru, Fakulteta za organizacijske vede, Kranj, Slovenija. \\ E-pošta: eva.jereb@um.si.marko.urh@um.si
}

Povzetek Vsaka kriza pripelje do sprememb, bodisi na ravni organizacije ali na ravni posameznika. Pomembno je, da se tega zavedamo, in nadalje, da se zavedamo, da prihaja do tranzicije, skozi katero prehajamo, ko se soočimo s spremembo. Če gre tukaj za organizacijo in zaposlene, ki se srečujejo s spremembami, ima pri tem vodstvo še posebej pomembno vlogo. Prispevek obravnava spremembe in tranzicije, skozi katere prehajajo zaposleni $\mathrm{v}$ času krize, in vlogo vodstva pri tem. Najprej so predstavljeni pojmi kriza, spremembe in tranzicija. Nato so opredeljeni različni modeli tranzicije, kot so: krivulja sprememb Kübler-Ross, ki opisuje pet stopenj, skozi katere prehajajo posamezniki ob soočenju s spremembo; tranzicijski model po Bridgesu, ki omenja tri faze prehajanja $\mathrm{v}$ času sprememb; nevrologistične stopnje sprememb po Diltsu, ki naj bi posamezniku pomagale raziskati problem in priložnosti ter pri tem definirati ovire, ki preprečujejo spremembo. Skozi celoten prispevek, predvsem pa na koncu, so podani določeni elementi, ki jih je smiselno upoštevati pri vodenju zaposlenih v času krize, sprememb in tranzicije.

Ključne besede:

kriza, krivulja sprememb, tranzicija, zaposleni, vodenje. 


\title{
Change and Transition in Time OF CRISIS AND THE ROLE OF LEADERSHIP
}

\author{
EVA JEREB \& MARKO URH \\ University of Maribor, Faculty of Organizational Sciences, Kranj, Slovenia. \\ E-mail: eva.jereb@um.si.marko.urh@um.si
}

Keywords:

crisis,

change

curve,

transition,

employees,

leadership.

\begin{abstract}
Every crisis leads to change, both at the level of the organization as well as the individual. It is important to be aware of this and further, to be aware that there is a transition we go through when we face change. In the case of organizations and employees who are facing change, leadership has a particularly important role to play. The article deals with the changes and transitions that employees go through during the crisis and the role of management in this. First the concept of crisis, change and the transition is presented. Then, different models of transition are identified, such as the Kübler-Ross change curve, which describes the five stages that individuals go through in the face of change; the Bridges transition model, which mentions three stages of transition in times of change; neuro logistic rates of change according to Dilts, which are intended to help the individual explore the problem and the opportunities and to identify obstacles that prevent change. Throughout the paper, but especially, in the end, certain elements are given that should be taken into account when managing employees in times of crisis, change and transition.
\end{abstract}




\section{Uvod}

Danes nihče ni imun na krizo. Lahko prizadene vsakogar, katero koli podjetje ali organizacijo, ne glede na njeno velikost ali panogo, ne glede na to, ali gre za profitno ali neprofitno dejavnost. Zato bi morala biti vsaka organizacija pripravljena na krizne dogodke, ki lahko negativno vplivajo na ugled organizacije, dobiček ali poslovne oziroma organizacijske cilje (Haggerty, 2017).

Nekatere krize nastanejo zaradi napak in neuspehov organizacij samih, druge pa izhajajo iz zunanjih dejavnikov, ki vplivajo na svetovno gospodarstvo in organizacije po vsem svetu (James, Wooten, \& Dushek, 2011). Ne glede na to, zaradi česa pride do krize, je vsaka kriza povezana s spremembami in tranzicijo. Sprememba pa lahko ogroža delovna mesta, moč in status posameznika v organizaciji ter ustaljene vzorce delovnih odnosov. Vsak posameznik na krizo reagira drugače. Za nekatere predstavlja specifična situacija krizo, za druge priložnost za nov začetek, možnost za boljše, drugačno delo in podobno. Ne glede na to, ali na situacijo gledamo kot na krizo ali priložnost, le-ta zahteva spremembe, ki pa se jim zaposleni lahko upirajo. Upiranje pa upočasni proces spreminjanja in vpliva na ustvarjanje občutka nujnosti in povzroča zmedo. Če je sprememba težavna in je vodstvo pod stresom, se bo lahko skušalo izogniti tistim, ki se upirajo, ali pa bo prišlo z njimi v konflikt. Čeprav je najlažje izločiti upornike iz postopka uvajanja sprememb, je zaradi nadaljnjega sodelovanja in doseganja dobrih rezultatov le-te smiselno poskusiti pridobiti na svojo stran in vključiti v sam proces sprememb, da bi dejansko lahko uspešno dosegli želeno spremembo in napredek (Tasmanova vlada, 2020).

Zaposleni se poleg soočanja s krizami in spremembami v podjetju s tem srečujejo tudi v osebnem življenju in pomembno je, da vodje gledajo na vsakega zaposlenega in ga upoštevajo kot celoto. Poleg sprememb in tranzicij, povezanih z delom, ljudje doživljajo spremembe in tranzicije tudi v osebnem življenju skozi različna življenjska obdobja. Zato je pomembno, da so vodje seznanjeni z različnimi tranzicijskimi modeli ali krivuljami sprememb, s katerimi se zaposleni spopadajo, ko se soočajo s takšno ali drugačno spremembo. 


\section{$2 \quad$ Kriza}

Obstaja veliko različnih definicij krize. Bernstein (2011) definira krizo kot vsako situacijo, ki povzroči ali bi lahko povzročila škodo ljudem ali njihovemu premoženju, ki bi lahko resno prekinila poslovanje podjetja, škodovala ugledu in/ali negativno vplivala na vrednost podjetja. Kramer in Tyler (1995) krizo opredeljujeta kot veliko grožnjo preživetju sistema, ki ima malo časa za odziv in vključuje slabo strukturirano situacijo z neustreznimi sredstvi za spopadanje z njo.

V slovarju Oxford Dictionaries Online je kriza definira kot čas izrednih težav ali nevarnosti; čas, ko je treba sprejeti težko ali pomembno odločitev. V antični Grčiji se izraz kriza nanaša na kritično točko na poti razvoja, trenutek odločitve (Boin, 't Hart, \& Kuipers, 2018). Glede na slovar Oxford Dictionaries Online, kriza na medicinskem področju pomeni prelomnico bolezni, ko pride do pomembne spremembe, ki kaže na ozdravitev ali smrt. Kar je podobno, kot navajajo Boin, 't Hart in Kuipers (2018), in sicer da se kriza nanaša na kritično fazo pacientovega boja proti smrtonosni grožnji: bo živel ali umrl?

Spletni slovar Meriam-Webster pojmuje krizo še širše, in sicer kot:

1. ključno ali odločilno točko ali situacijo; prelomnico,

2. nestabilne razmere $\mathrm{v}$ političnih, socialnih, gospodarskih ali vojaških zadevah, zlasti tiste, ki

vključujejo bližajoče se nagle spremembe,

3. nenadno spremembo poteka bolezni, običajno tisto, pri kateri se pričakuje, da bo bolnik okreval ali umrl,

4. travmatično ali stresno spremembo $v$ človekovem življenju,

5. točko v drami, v kateri konflikt doseže vrhunec, preden se razreši.

James in Gilliland (2013) opisujeta krizo kot zaznani dogodek ali situacijo, kot neznosno težavo, ki presega trenutne vire in mehanizme posameznika za spopadanje s tem dogodkom oziroma situacijo.

Po Rosenthalu, Charlesu in 't Hartu (1989) govorimo o krizi, ko skupina, organizacija ali skupnost doživijo resno grožnjo osnovnim strukturam ali temeljnim vrednotam in normam sistema, kar pod časovnim pritiskom in zelo negotovimi okoliščinami zahteva sprejemanje življenjsko pomembnih odločitev. Ta opredelitev krize nam 
omogoča zajem najrazličnejših stisk, kot so: naravne katastrofe in nevarnosti za okolje, finančni zlomi, teroristični napadi, izbruhi epidemij, infrastrukturni zlomi, propadi organizacij in drugo. Vsem tem dogodkom je skupno to, da ustvarjajo nemogoče pogoje za tiste, ki odločajo in želijo upravljati odzivne operacije. Prisili jih $\mathrm{k}$ nujnemu odločanju v času, ko so bistvene informacije o vzrokih in posledicah nedosegljive, nezanesljive ali nepopolne. Kriza ogroža visoko prioritetne cilje odločevalcev, omejuje čas, ki je na voljo za oblikovanje odločitev, in preseneča že samo s svojim pojavljanjem (Hermann, 1972).

Po Lebringerju (2012) so za organizacijsko krizo značilni naslednji elementi:

- dogodek je nenaden, nepričakovan in nezaželen,

- odločitve je treba sprejeti hitro,

- gre za dogodek z majhno verjetnostjo in velikim vplivom,

- ima dvoumnost vzrokov, posledic in načinov reševanja; prekine normalno delovanje organizacije,

- ovira visoko prioritetne cilje in ogroža dobičkonosnost, rast in preživetje podjetja,

- lahko povzroči obsežno poslabšanje razmer in nepopravljivost situacije, če ne ukrepamo; ustvarja velik psihološki stres.

Do krize pride, ko so ogrožene temeljne vrednote ali sistemi, ki vzdržujejo življenje skupnosti. Splošne, skupne vrednote, kot so varnost, dobro počutje in zdravje, celovitost in pravna država, zaradi nasilja, uničenja, škode in podobnega postanejo razmajane ali celo brez pomena. Ko kritične infrastrukture ne vzdržijo, je ogroženo normalno delovanje sodobne družbe (Boin, Hart, \& Kuipers, 2018).

Olafsson (2013) pravi, da kriza vpliva na ključne človeške potrebe, to je potrebe po gotovosti in udobju. Vsi si želimo udobja. Velik del tega udobja pa izvira iz gotovosti. Seveda ni absolutne gotovosti, vendar vsi želimo, da nam avto vžge, da voda priteče iz pipe, da je valuta, ki jo uporabljamo, stabilna in tako dalje. Roberts (2002) krizo definira kot akutno motnjo psihološke homeostaze, pri kateri običajni mehanizmi obvladovanja ne delujejo in obstajajo dokazi o stiski in funkcionalni oslabitvi. Subjektivna reakcija na stresno življenjsko izkušnjo ogroža posameznikovo stabilnost in sposobnost obvladovanja situacije in delovanja. Glavni vzrok za krizo je intenziven stresni, travmatični ali nevarni dogodek, vendar sta potrebna tudi dva 
druga pogoja: posameznikovo dojemanje dogodka kot vzroka za velike motnje ter posameznikova nezmožnost, da bi motnjo odpravil z že doslej uporabljenimi mehanizmi za spopadanje.

Nekateri pripisujejo oznako krize le najbolj skrajnim negativnim dogodkom, kot so na primer: strmoglavljenje letala Malaysia Airlines flight 370, cianid v zdravilu Tylenol ipd. Drugi pripisujejo izraz krize samo tistim incidentom, ki zahtevajo obveščanje $\mathrm{v}$ nujnih primerih, kot na primer: orkani in drugi vodni dogodki, razlitja nafte, terorizem ali druge nesreče $\mathrm{v}$ kazenski ali nacionalni varnosti in podobno (Haggerty, 2017).

Število in raznolikost kriz, ki jim je potencialno podvržena katera koli organizacija, je neomejeno: okoljske katastrofe, pravni izzivi, problemsko vedenje zaposlenih, delovni spori, prekinitve dobavne verige, napake na izdelkih, potrošniški aktivizem, uhajanje pomembnih informacij in tako naprej (Bernstein, 2011).

Po Haggertyju (2017) obstajata dve glavni kategoriji kriz: eksplozivne krize in krize, ki se približujejo počasi oziroma se odvijajo s časom. Eksplozivna kriza je trenutna kriza, ki se naenkrat pojavi na prizorišču (npr. nesreča, požar ali eksplozija). S časom nastajajoče krize so krize, ki se pojavijo sčasoma oziroma se razvijajo skozi daljše časovno obdobje, na primer tožba ali preiskava. Bernstein (2011) krizo deli na tri splošne kategorije: plazeča kriza, kriza s počasnim izgorevanjem in nenadna kriza. Plazeče krize so krize, ki jih napoveduje vrsta dogodkov, ki pa jih odločevalci ne zaznajo in ne obravnavajo kot potencialne vzroke za krizo. Kriza s počasnim izgorevanjem je kriza, ki že vnaprej opozarja nase, vendar razmere še niso povzročile dejanske škode. Nenadna kriza je kriza, pri kateri je škoda že nastala in se bo poslabšala, dlje kot traja odziv. Mileti (1999) opredeljuje tri stopnje krize: vsakdanje nesreče (na primer prometne nesreče in požari poslopij), naravne večje nesreče (na primer potresi in poplave) in katastrofe (na primer Hirošima). Lahko bi jih poimenovali tudi vsakdanje krize, velike krize in katastrofe. Olafsson (2013) pravi, da so po Miletijevih besedah običajen vzrok vsakodnevnih kriz ali izrednih razmer ljudje, saj pogosto počnejo stvari, ki jih ne bi smeli početi. V teh primerih je ugotovil, da se običajno lahko obrnemo na organizacije, ki nam pomagajo pripeljati stvari v normalno stanje. Ko na pomoč priskočijo ljudje iz teh organizacij (na primer gasilci ali policisti), njihove pomoči ne jemljemo osebno, temveč smatramo, da opravljajo svoje dolžnosti po poklicu. V nasprotju s tem pa so krize, ki se pojavijo v okviru podjetja ali organizacije, kjer so pogosto zaposleni tisti, ki se morajo spopasti s krizo 
in rešiti nastalo situacijo. V teh primerih ni nekih organizacij, ki bi jih lahko poklicali, da nam razrešijo nastalo situacijo oziroma krizo. V času takih kriz se organizacije po navadi borijo za pozornost medijev in javnosti, velikokrat gre za politične boje, pri čemer skušajo krizo izkoristiti, da dokažejo svoj pomen in obstoj. Tretja stopnja krize so katastrofe. Kot primer tega je atomska bomba na Hirošimi: reševalna ekipa medicinskih sester je obupala, ko se je število hudo ponesrečenih v zelo kratkem času podvojilo in so umirali vsakih pet minut. Enostavno jih je premagal občutek nemoči in popolne prevlade nastale situacije, ki ji niso bile več kos. Na srečo lahko omenimo dve pozitivni stvari glede katastrof: eno je, da se zgodijo zelo redko, drugo pa, da običajno hitro izstopimo iz tega stanja nemoči.

V krizah dojemanje grožnje spremlja velika stopnja negotovosti. Ta negotovost se nanaša na nastalo situacijo oziroma grožnjo in prav tako na morebitne posledice (Boin, 't Hart, \& Kuipers, 2018). Negotovost pa ostaja tudi v času iskanja rešitev. Začnemo si postavljati vprašanja, kot so: »Kaj se dogaja? Zakaj se je zgodilo? Kako hudo bo? Kaj lahko naredim/o? Kaj se bo zgodilo, če izberem/o določeno možnost rešitve? Kaj to pomeni zame/za nas? Kako bodo ljudje reagirali?« Pri vsem tem se moramo zavedati, da je vsaka kriza povezana s spremembami. Ko je krize konec, nič več ne ostane enako. Sledi vprašanje »Kako bom/o kos vsem spremembam?«

$\mathrm{V}$ naslednjem poglavju je predstavljen pomen sprememb za posameznika in organizacijo ter prehajanje skozi različne faze oziroma tranzicija.

\section{$3 \quad$ Spremembe in tranzicija}

Spremembe so neizogiben del življenja in od njih nima smisla bežati. Če je sprememba dobro načrtovana in formulirana, lahko prinese pozitivne rezultate (Anastasia, 2015) oziroma učinke. Vendar je kljub dobremu načrtovanju sprememb v organizaciji ali na osebni ravni posameznika le-te težko vključiti, sprejeti in ceniti.

Sprememba je situacijsko pogojena, bodisi da gre za nek zunanji dogodek, uvedbo nove strategije, spremembo vodstva, združitev podjetij, lansiranje novega izdelka itd. Organizacija se v tem primeru osredotoča na rezultat, ki ga bo prinesla sprememba, ki je v bistvu odziv na zunanje dogodke. Lahko se zgodi zelo hitro, lahko pa bolj počasi. Tranzicija pa je notranji psihološki proces, ki ga ljudje doživljajo, ko ponotranjijo in se sprijaznijo z novonastalo situacijo, ki jo spremembe prinesejo. Izhodišče za spopadanje s tranzicijo ni rezultat, ampak so zaključki, ki jih imajo in 
doživljajo posamezniki, ko puščajo staro situacijo za seboj. Pripeljati ljudi skozi tranzicijo je bistvenega pomena, če želimo, da se bo sprememba dejansko odvijala po načrtih (Wlliam Bridges Associates, 2020) in da bomo dosegli želene rezultate.

Tranzicija sama pomeni za posameznika spremembo. Življenjske situacije zahtevajo, da kot posamezniki vedno znova preučujemo trenutni način življenja, in nas prisilijo, da se razvijamo in rastemo (Adelman, 2020). Življenjski prehodi oziroma tranzicije so zahtevne, ker nas silijo, da se odrečemo znanemu in se z občutkom ranljivosti soočimo s prihodnostjo (Joelson, 2020). Toda tudi ko se zavedamo, da je tranzicija $\mathrm{v}$ našo korist, se $z$ njo še vedno zelo težko čustveno spoprimemo. Tranzicije so lahko predvidljive, na primer selitev ali prihajajoča poroka, ali pa so nepredvidljive, na primer smrt ljubljene osebe ali nenadna izguba službe (Adelman, 2020). Po Joelsonu (2020) se večina življenjskih prehodov začne $z$ nizom izgub: izguba določene vloge v življenju, izguba človeka, izguba delovnega mesta, izguba občutka pripadnosti nečemu ipd. Ob vsaki pomembni izgubi večina ljudi občuti strah in tesnobo. Ne glede na to, ali so dogodki pozitivni ali negativni, življenjski prehodi silijo posameznika $\mathrm{k}$ temu, da pusti za sabo že znano in se vsaj začasno prilagodi novim načinom življenja. To posameznika lahko pripelje $\mathrm{v}$ situacijo, ko se počuti popolnoma nepripravljenega in lahko zapade $\mathrm{v}$ osebno krizo, postane pretresen, jezen, žalosten in umaknjen.

Ne glede na dogodek nas vsak prehod, ki ga doživimo, prisili, da spremenimo svoje obstoječe življenje. Vemo, da je sprememba neizogiben del življenja, vendar to ne pomeni, da je vedno prijetna. To velja še posebej takrat, kadar so premiki nenadni ali nepričakovani. Ta čas za nas lahko predstavlja notranjo borbo, ker se naša pričakovanja o našem življenju ne ujemajo s trenutnim stanjem ali odvijanjem dogodkov (Adelman, 2020). Tranzicija oziroma življenjski prehod je lahko pozitiven ali negativen, načrtovan ali nepričakovan. Nekateri prehodi se zgodijo brez opozorila in so lahko precej dramatični, kot v primerih nesreč, smrti, ločitve, izgube službe ali resne bolezni. Druge tranzicije izhajajo iz pozitivnih izkušenj, kot so poroka, odhod na fakulteto, začetek nove službe, selitev v novo mesto ali rojstvo otroka. Čeprav so dogodki, kakršni so ti, običajno načrtovani in predvideni, pa lahko pomenijo prav tako spremembo v življenju kot nepričakovani dogodki (Joelson, 2020). 
Ko je naša prihodnost polna vprašanj, je normalno, da občutimo strah. Živimo v času in kulturi, kjer smo se naučili, da se zaradi negotovosti počutimo zelo neprijetno, zato postanemo zaskrbljeni, ko je moteno naše vsakodnevno življene. S spremembami pa pride odpor. Velik življenjski prehod zapre eno poglavje našega življenja in odpre novo. Pogosto je prilagajanje zelo težko, ker zelo intenzivno občutimo strah in negotovost (Adelman, 2020). Po drugi strani pa nam ti prehodi ponujajo priložnost spoznati svoje prednosti in raziskati, česa si v resnici želimo od življenja. Vse to lahko povzroči dober občutek, občutek prenove, stabilnosti in novega ravnovesja (Joelson, 2020).

\section{$4 \quad$ Tranzicijski modeli}

\section{Krivulja sprememb Kübler-Ross}

Krivulja sprememb Kübler-Ross, ki je znana tudi kot krivulja petih stopenj žalosti, je model, sestavljen iz različnih faz ali stopenj čustev, ki jih doživi oseba, ki se približuje smrti. Pet stopenj, vključenih v ta model, predstavlja: zanikanje, jezo, pogajanje, depresijo in sprejemanje. Ta model je predstavila Elisabeth Kübler-Ross v knjigi z naslovom »Smrt in umiranje«, ki je izšla leta 1969 (Anastasia, 2015), in je model po njej dobil tudi ime. Hall (2015) navaja, da je Elizabeth Kübler-Ross pozneje dodala še eno stopnjo, in sicer stopnjo adaptivnega vedenja. Različic krivulje sprememb je veliko. Na sliki 1 je prikazana ena od njih. Danes je običajno razvrščanje $\mathrm{v}$ tri faze: šok ali zanikanje, jeza in depresija ter sprejemanje in vključevanje (Hall, 2015). 


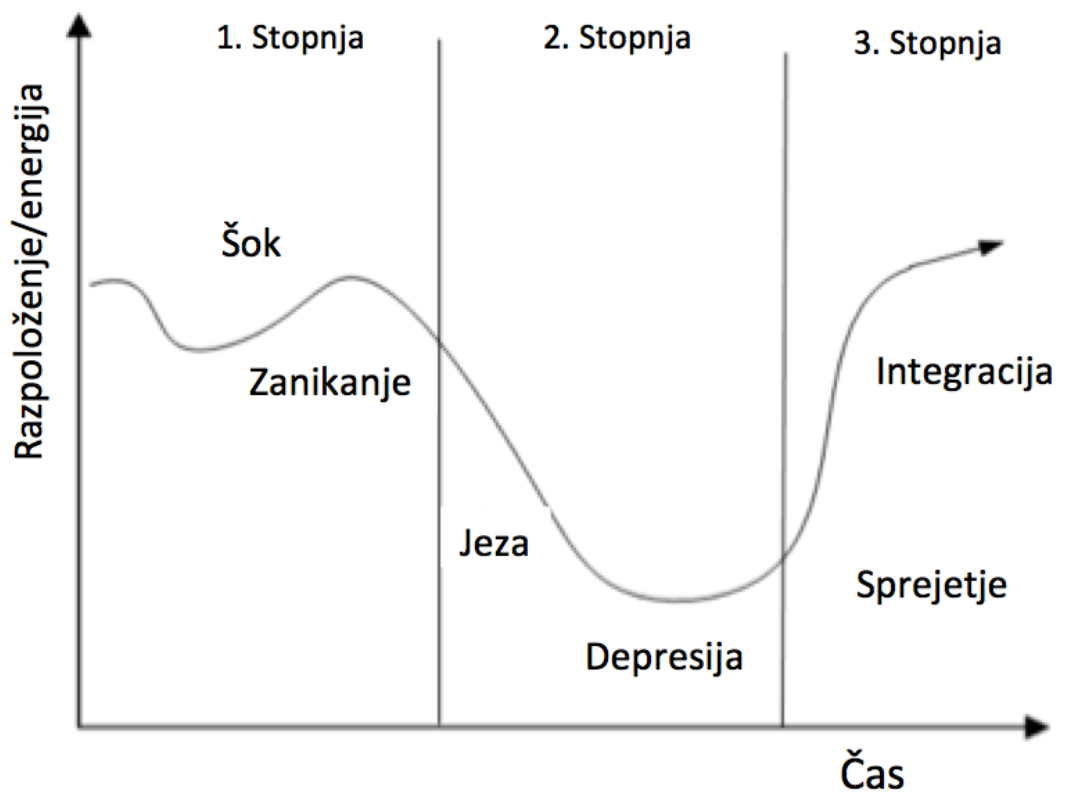

Slika 1: Krivulja sprememb Kübler-Ross

(Zupančič, 2018)

Zanikanje je običajno začasna obramba, ki nam daje čas, da sprejmemo novice o spremembah, preden se premaknemo na druge stopnje. Je začetna stopnja otopelosti in šoka. Nočemo verjeti, da se sprememba dogaja (Connelly, 2018). Lahko prinese padec produktivnosti in sposobnosti razmišljanja in delovanja. Potem ko začetni šok popusti, lahko pri posamezniku pride do zanikanja in ostane osredotočen na preteklost. Ta faza je večinoma kratkotrajna, vendar nekateri pogosto ostanejo v stanju zanikanja in lahko izgubijo stik z resničnostjo (Anastasia, 2015).

Jeza predstavlja obdobje, ko posameznik končno pride do spoznanja in razume težo situacije. Pri tem lahko postane jezen in išče krivdo v drugih. Jeza se lahko manifestira ali izrazi na več načinov. Medtem ko se nekateri jezijo nase, lahko drugi usmerijo jezo na druge okoli sebe. Medtem ko so nekateri na splošno jezni na življenje, lahko drugi za nastalo situacijo krivijo gospodarstvo. V tej fazi človek vedno ostane razdražljiv in frustriran (Anastasia, 2015). 
V organizaciji se nekateri po nepotrebnem bojijo negativnih posledic sprememb. Drugi pa dejansko lahko pravilno prepoznajo resnične grožnje svojim položajem. Zaradi tega organizacija doživi motnje, ki se lahko, če jih skrbno ne obvladujemo, hitro prelevijo v kaos. Dokler se ljudje upirajo spremembi in ostajajo v drugi fazi krivulje sprememb, bo sprememba neuspešna vsaj za tiste posameznike, ki reagirajo na ta način. To je stresna in zelo neprijetna faza (Mind Tools, 2018a).

Pogajanje. Ko faza jeze mine, nekateri lahko začnejo razmišljati o načinih, kako bi to, kar je sicer neizogibno, preložili. Tisti, ki se ne soočajo s smrtjo, ampak z neko drugo travmo, se v tej fazi poskušajo pogajati in pridejo do določenega kompromisa. Pogajanja lahko pripeljejo do trajnostne rešitve in lahko olajšajo situacijo tistim, ki se približajo nečemu, čemur se želijo v celoti izogniti. V tej fazi se lahko nadaljuje iskanje drugačnega ali manj travmatičnega izida (Anastasia, 2015). Ta pogajanja so bodisi dogovori z bogom, z drugimi ali s samim življenjem. V delovnih razmerah lahko nekdo bolj trdo dela in opravi veliko nadur, da se izkaže za neprecenljivega, da bi se tako izognil odpustitvi oziroma izgubi delovnega mesta (Connelly, 2018).

Depresija. Ko se posameznik zave, da pogajanje ne bo delovalo, se sooči s spremembo. Na tej točki se zaveda izgub, povezanih s spremembo, in čemu se mora odreči oziroma kaj mora zapustiti. To pa lahko povzroči žalost, posameznik se počuti na tleh, postane depresiven z nizko ravnjo energije (Connelly, 2018). Depresija je stopnja, $v$ kateri oseba običajno občuti žalost, strah, obžalovanje, krivdo in druga negativna čustva. Morda v tem trenutku celo obupa, pride v slepo ulico, iz katere ne vidi več izhoda, le še temo. Posamezniki, ki se nahajajo v fazi depresije, so običajno ravnodušni, potiskajo druge stran od sebe in so apatični do česarkoli v življenju. To se lahko zdi kot najnižja točka v življenju brez poti naprej. Nekateri pogosti znaki depresije so žalost, nizka energija, občutek demotiviranosti, izguba zaupanja v boga itd. (Anastasia, 2015). Stadij depresije je pogosto opazen na različne načine tudi na delovnem mestu. Ljudje, ki se soočajo s spremembami na delovnem mestu, se lahko počutijo demotivirane in negotove glede svoje prihodnosti (Connelly, 2018).

Sprejemljivost. Ko ljudje spoznajo, da boj s spremembo, ki prihaja v njihovo življenje, ne bo odpravil negativnih občutkov, se sprijaznijo s situacijo in jo v celoti sprejmejo. Spremenjen odnos morda ne predstavlja sreče, ampak možnost, da se posameznik neha upirati spremembam in se premakne naprej (Anastasia, 2015). Ko pri posamezniku sprejemanje spremembe narašča, bo kmalu poskušal preizkusiti in 
raziskati, kaj sprememba zanj pomeni, kaj prinaša. Ta proces bo potekal veliko laže, če se jim pri tem pomaga in se jih podpira, četudi to preprosto pomeni samo to, da jim damo dovolj časa, ki ga potrebujejo (Mind Tools, 2018a).

Kübler-Ross pri razlagi teh faz pojasni, da gre za normalne reakcije posameznika na tragične novice. Pravzaprav jih je poimenovala obrambni mehanizmi ali mehanizmi za obvladovanje, skozi katere moramo iti, da obvladamo spremembe. Pri tem se skozi te faze ne premikamo po korakih, linearno, korak za korakom. To bi bilo preveč enostavno. Dogaja se, da se v različnih obdobjih nahajamo v različnih fazah in se lahko celo premaknemo nazaj na predhodno fazo, na kateri smo bili prej. Kübler-Ross tudi navaja, da je čas trajanja faz različen in da določena faza lahko nadomesti drugo fazo ter da se lahko odvijajo tudi vzporedno. Idealno bi bilo, da bi kar najhitreje dosegli fazo sprejemanja, vendar temu ni vedno tako. Nekateri posamezniki obstanejo $\mathrm{v}$ določenih fazah in se težko ali celo ne morejo premakniti naprej (Connelly, 2018).

Model je bil prvotno namenjen iskanju značilnih odzivov ali obrambnih mehanizmov na novice, kot sta smrtna bolezen ali smrt ljubljene osebe, potem pa je bil prilagojen in se pogosto uporablja za pomoč ljudem pri odkrivanju občutenj na različnih področjih, povezanih s soočanjem s kakršnimi koli pomembnimi spremembami ali preobrati (po Talbott, 2013 v Hall, 2015).

Model krivulje Kübler-Ross velja tudi, ko gre za posel, delo ali zaposlitev. Vsaka organizacija mora slej ko prej uvesti spremembe, bodisi na področju vodenja, politike podjetja ali/in drugje. Toda poleg spremembe in izboljšanja sistemov se morajo spremeniti tudi ljudje oziroma zaposleni. Ne glede na uvedbo sprememb v sistemih in procesih, zaposleni $\mathrm{v}$ podjetju največkrat vztrajajo pri starih načinih dela in se upirajo spremembam. V tem primeru nismo dosegli prav veliko ali smo celo izgubili vloženi denar. Zato je izrednega pomena, da se tudi zaposleni temu ustrezno prilagodijo in spremenijo. Šele ko so se zaposleni pripravljeni spremeniti in iti skozi določene tranzicije, lahko podjetje pričakuje napredek in izkoristi prednosti sprememb (Anastasia, 2015).

Dejstvo je, da se organizacije ne spreminjajo samo zaradi novih sistemov, procesov ali struktur. Spreminjajo se, ker se ljudje znotraj organizacije tudi prilagajajo in spreminjajo. Šele ko so ljudje opravili svoje osebne prehode, lahko organizacija resnično izkoristi prednosti uvedenih sprememb. Ko je sprememba v okviru 
organizacije neizogibna, je izrednega pomena pomagati in podpirati zaposlene v času njihovega spreminjanja in tranzicije, kajti včasih so lahko ti prehodi zelo travmatični in vključujejo izgubo moči in prestiža ali celo zaposlitve (Mind Tools, 2018a).

Vsaka organizacija mora podpirati zaposlene pri prehodu in spremembah. Čim lažje se bodo zaposleni premikali na svoji poti, lažje bo organizacija napredovala k uspehu. To vpliva na stopnjo uspešnosti in celotni dobiček podjetja. Krivulja sprememb v poslovanju je tako pomemben model, ki nam lahko pomaga razumeti in se soočiti s spremembami in osebnimi prehodi. Pomaga razumeti, kako se bodo zaposleni odzvali na spremembe in kako zagotoviti podporo med procesom sprememb (Anastasia, 2015).

Večina svetovalcev na področju organizacijskih sprememb se strinja, da se ljudje na organizacijske spremembe odzovejo na načine, ki so podobni krivulji sprememb Kübler-Ross (Hall, 2015). Krivulja sprememb je priljubljen in pomemben model, ki se uporablja za razumevanje faz osebnega prehoda in organizacijskih sprememb. Pomaga napovedati, kako se bodo ljudje odzvali na spremembe, tako da jim lahko pomagamo pri njihovih osebnih prehodih in poskrbimo, da bodo imeli vsa navodila in podporo, ki jo potrebujejo (Mind Tools, 2018a).

\section{Bridgesov tranzicijski model}

Bridgesov tranzicijski model ali model prehoda je model, ki podjetju ali posamezniku pomaga pri organizacijskih spremembah (Janse, 2019). Glavna moč modela je, da se osredotoča na tranzicijo oziroma prehod in ne na spremembe. Razlika med njima je subtilna, a pomembna (Crowe Associates Ltd., 2020). Ravno prehod je pogosto neprijeten za ljudi, kar vodi v odpor. Spremembe se največkrat uvajajo z namenom, da bodo stvari bolj učinkovite, varne ali enostavne. Čeprav naj bi uvedba sprememb koristila organizaciji in doprinesla $\mathrm{k}$ njeni uspešnosti, se zaposleni pogosto upirajo njeni uvedbi in postanejo največja ovira, kar pa jim glede na Bridgesov model prehoda ni potrebno biti. Skozi ta model Bridges pomaga razjasniti osebni vidik upravljanja sprememb in prikazuje zaposlene kot podpornike in ne ovire (Janse, 2019). 
Model tranzicije je ustvaril svetovalec za spremembe William Bridges. Objavljen je bil leta 1991 v njegovi knjigi »Upravljanje prehodov« (Mind Tools, 2018b). Bridges pojasnjuje razliko med prehodom in spremembo. Spremembe se zgodijo hitro in ljudje pogosto nimajo nobene besede pri tem. Prehod pa je počasnejši proces, ki se dogaja znotraj posameznika. Prehod je tisto, kar se dogaja v glavah ljudi, ko gredo skozi proces spreminjanja. Model govori o treh stopnjah prehoda, in sicer: konec, izguba in izpustitev; nevtralna cona in nov začetek (slika 2). Pomembno je vedeti, da gre vsak posameznik skozi proces s svojo hitrostjo. Nekateri so bolj dovzetni za spremembe in gredo zelo hitro skozi vse tri stopnje. Drugi so bolj zakoreninjeni v svojih trenutnih načinih in bodo potrebovali veliko dlje (Pearson, 2020).

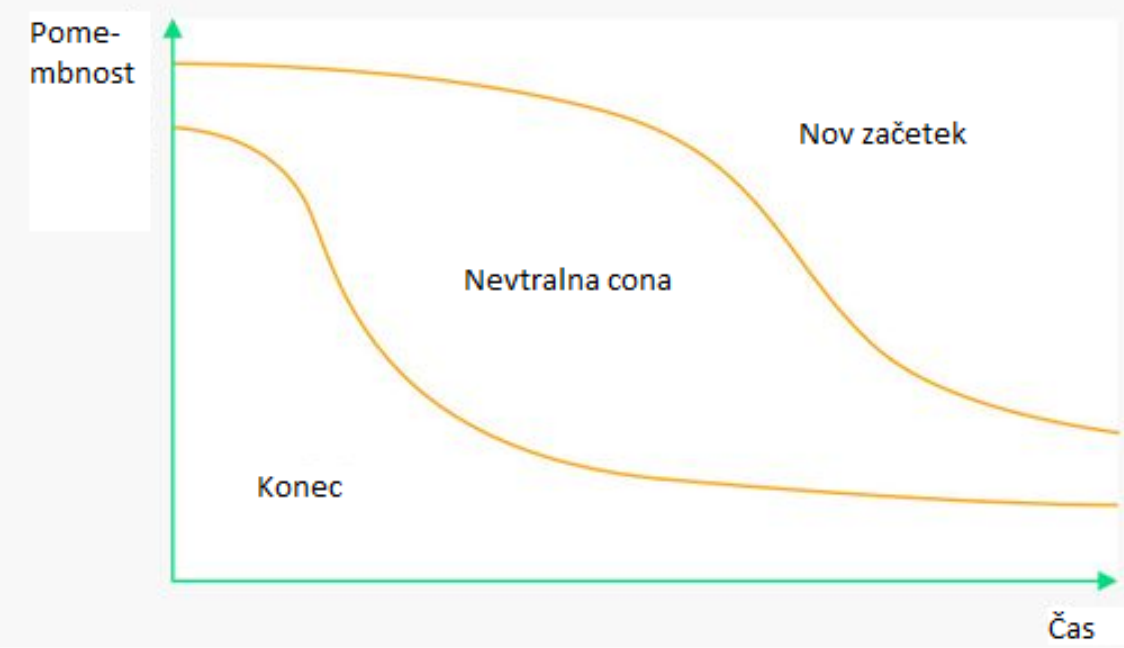

Slika 2. Bridgesov tranzicijski model

(Janse, 2019)

Konec. Prehod se začne s koncem. To je paradoksalno, vendar resnično. Ta prva faza prehoda se začne, ko ljudje ugotovijo, kaj izgubljajo, in se naučijo, kako upravljati s temi izgubami (Wlliam Bridges Associates, 2020). Izgube običajno lahko porazdelimo $\mathrm{v}$ šest kategorij, in sicer izguba navezanosti, ukoreninjenosti, strukture, prihodnosti, pomena in nadzora (Hall, 2015). V tej fazi ljudje ugotovijo, česa vsega je konec, kaj bodo pustili za seboj in kaj obdržali. To lahko vključuje medosebne odnose, procese, člane tima ali lokacije (Wlliam Bridges Associates, 2020). 
Po mnenju Janseja (2019) lahko ta faza predstavlja za zaposlene pravi čustveni vrtiljak. Pojavijo se lahko občutki tesnobe, žalosti, frustracije in osamljenosti ali celo depresije. Za spopadanje s temi občutki je potrebno potrpljenje. Pomembno je, da ljudi spodbujamo, da so odprti do svoje čustvene reakcije na spremembe in da sprejemajo občutke z razumevanjem. Pomembno je, da se pogovorimo z njimi o spremembi, ki se bo zgodila, in da smo odprti ter razložimo, zakaj je le-ta potrebna. Zaposleni morajo biti seznanjeni o svojih prihodnjih vlogah v podjetju in o pomoči, ki jo lahko dobijo, da se prilagodijo novim načinom dela. Bridges je verjel, da je čustvena reakcija na spremembe $v$ veliki meri odziv na soočenje $z$ neznanim ali s tistim, česar ljudje ne razumejo. Če jim zagotovimo, da bodo njihove sposobnosti za organizacijo še naprej pomembne in jim prikažemo pozitivne rezultate, ki jih bodo prinesle spremembe, jim s tem lahko pomagamo, da bodo spustili staro in se pripravili na prehod v naslednjo fazo (Pearson, 2020). Jasno bi moralo biti razvidno, da bodo zaposleni pri tem deležni podpore, vendar se to žal zgodi le redko. Vodje lahko zaposlenim močno olajšajo prehod zaradi uvedene spremembe, in sicer tako, da (Janse, 2019):

- jasno razložijo namen spremembe,

- spoštujejo in cenijo čustva sodelavcev,

- pojasnijo prednosti načrtovane spremembe,

- pojasnijo natančno, kaj se bo spremenilo in kaj bo ostalo enako,

- veliko komunicirajo s podrejenimi oziroma sodelavci.

Nevtralna cona. Izpustitvi oziroma koncu sledi drugi korak, to je nevtralna cona. Ljudje gredo skozi to cono oziroma vmesni čas, ko starega več ni, novo pa še ne deluje v celoti. $\mathrm{V}$ tem času potekajo kritične psihološke preusmeritve in ponovno »nalaganje« vzorcev. To predstavlja samo jedro procesa prehoda. Je čas med staro resničnostjo in identiteto ter novo. Ljudje ustvarjajo nove procese in se učijo, kakšne bodo njihove nove vloge, toda to je še vse v teku in se še ne počutijo udobno. Gre za iskanje novih začetkov (Wlliam Bridges Associates, 2020).

Po mnenju Pearsona (2020) v času, ko ljudje vstopijo v nevtralno cono, še niso povsem poistoveteni s spremembami in bodo še vedno potrebovali veliko spodbude. Zdaj je sprememba neizogibna. Zgodila se je in ljudje se navajajo na nove načine dela. Krivulja učenja je stresna in nov način dela jim še ni domač. Ozirajo se nazaj in ugotavljajo, kako so stvari potekale včasih ter skrivaj ali odkrito menijo, da 
je bilo takrat prijetneje ali bolje. Istočasno pa se prilagajajo spremembam, ki jih uvaja organizacija. V tej fazi lahko opazimo naslednje reakcije zaposlenih:

- zaposleni ali posamezniki kažejo, da ne marajo spremembe,

- morala je nizka, prav tako produktivnost,

- počutijo se zaskrbljene in negotove glede njihove nove vloge in identitete $\mathrm{v}$ organizaciji,

- do pobude za spremembe so skeptični.

Zaposleni, ki se nahajajo $\mathrm{v}$ nevtralni coni, so po navadi nestrpni, zmedeni ali negotovi. Navajanje na nove procese, postopke ali odnose lahko povzroči povečan obseg dela. Najtežji koraki so bili opravljeni, vendar se mnogi zaposleni še vedno spopadajo $\mathrm{z}$ različnimi vprašanji ali negotovostjo, vključno s slabo moralo, zaskrbljenostjo glede njihovega položaja ali statusa in zamero. Vodje lahko vse to olajšajo, tako da (Janse, 2019):

- hitro oziroma ažurno odgovarjajo na vprašanja zaposlenih in dajejo povratne informacije,

- zagotovijo usposabljanje ali druge oblike pomoči,

- jasno pokažejo prednosti, ki jih bodo prinesle spremembe,

- ažurno in resno obravnavajo nastale situacije, vezane na uvedbo sprememb.

Novi ză̌etki vključujejo nova spoznanja, nove vrednote in stališča. Začetki so zaznamovani s sproščanjem energije v novo smer, so izraz sveže identitete. Dobro voden prehod omogoča, da se ljudje postavijo $v$ nove vloge $z$ razumevanjem namena le-teh ter tako kar najbolje prispevajo in sodelujejo. Preusmerili so se in prenovili (Wlliam Bridges Associates, 2020). Spuščanje preteklega oziroma starega je pri tem ključnega pomena za uspeh (Hall, 2015).

Spremembe so zdaj v celoti sprejete in zaposleni razvijajo nova znanja, potrebna za novo delovno okolje. Kazati se začnejo prvi rezultati in prednosti vseh naporov. Nova identiteta, ki je rezultat pravilno vodenega prehoda, omogoča zaposlenim, da razumejo smisel vsega tega. Razmišljajo o načinih, kako lahko učinkovito prispevajo in so del novega okolja. Čustva, ki jih v tej fazi doživljajo zaposleni, so veliko bolj pozitivna kot $\mathrm{v}$ prejšnjih fazah. To se kaže $\mathrm{v}$ njihovem delu in rezultatih, ki jih dosegajo. Po gladkem prehodu bodo zaposleni v tej fazi energični, željni učenja in 
se bodo počutili poistovetene z organizacijo (Janse, 2019). Seveda je to stanje, ki bi ga vsi vodje radi ohranili. In s pravilnim pristopom jim to lahko tudi uspe, lahko ohranjajo vzdušje optimistično in pozitivno. Vodja mora določiti cilje zaposlenih in jim razložiti, kako bo njihovo uresničevanje prispevalo $\mathrm{k}$ splošnim ciljem organizacije (Pearson, 2020). Da bi zgradili močne temelje za prihodnost, je smiselno, da poleg prej navedenega vodje (Janse, 2019):

- delajo na pomenu in smislu sprememb,

- so dosledni v vodenju, vedenju, komunikaciji in odločanju,

- pokažejo uspehe, ki jih je sprememba prinesla,

- praznujejo ter nagrajujejo rezultate in uspehe.

To je čas za praznovanje in nagrade, vendar ne smemo pozabiti, da nekateri lahko še vedno zdrsnejo nazaj na drugo stopnjo ali pa je sploh še niso zapustili. Še vedno moramo biti pozorni na določene zaposlene, ki potrebujejo pomoč (Pearson, 2020).

\section{Nevrologične ravni sprememb po Diltsu}

Zakaj je nekatere spremembe doseči veliko lažje kot druge? In ko jih enkrat dosežemo, zakaj nekatere trajajo dlje? Na osebni ali organizacijski ravni je vse povezano $z$ logično stopnjo, na kateri se nahajamo, ko poskušamo uvesti spremembo. Te logične ravni, ki jih je prvi predlagal Robert Dilts, se pogosto uporabljajo $\mathrm{v}$ nevrolingvističnem programiranju (NLP), vendar nudijo koristno strukturo za vpogled dogajanja v katerem koli posamezniku, skupini ali organizaciji (SkillsYouNeed, 2020).

Robert Dilts je organizacijski psiholog, ki je raziskoval spremembe in organizacijsko učenje. Ravni njegovega modela predstavljajo uporabno strukturo za poskušanje ugotavljanja smisla določenega dogajanja, bodisi na ravni posameznika, skupine ali organizacije. Ravni v modelu ustrezajo različnim nivojem nevrološkega vezja. Pogosto lahko vidimo, na kakšni ravni nekdo deluje po načinu govora, ki ga uporablja za razpravo o določeni težavi ali situaciji, po naravi oziroma vrsti njegovih vprašanj ali usmerjenosti njegove pozornosti (Discovery in Action, 2015). 
Logične ravni ponujajo posameznikom pomoč pri raziskovanju težav in priložnosti v osebnem ali poslovnem življenju. Hall (2015) navaja, da pomagajo prepoznati ovire za spremembe in odkrivajo, kje, tj. na kateri ravni, se spremembe lahko zgodijo. Ravni se imenujejo logične, ker morajo biti vse stopnje usklajene, preden se sprememba lahko zgodi in tudi obdrži. Teh šest stopenj predstavljajo (Talbott, 2013):

1. okolje (kje, kdaj in s kom?),

2. vedenje (akcije - kaj?),

3. zmogljivosti (kako?),

4. prepričanja in vrednote (zakaj?),

5. identiteta (kdo?),

6. poslanstvo (duhovnost: za kaj sem tukaj?).

Model je postavljen tako, da vsaka spodnja raven vpliva na zgornjo. S pomikanjem po hierarhiji navzgor pa vplivamo tudi na vse ravni spodaj (slika 3).

Okolje je vse, kar nas obdaja. Predstavlja prostor ali prostore, v katerih živimo, kjer smo opredeljeni z zunanjimi pogoji, $v$ katerih se odvija vedenje. Oseba, ki deluje na tej ravni, bo opazila prostor in ljudi okoli sebe (Turner, 2017) in bo verjetno razlagala, kaj se je zgodilo, kdo je bil tam in tako naprej. Na splošno zgodba ne bo o tem, kdo jo pripoveduje, njegova energija pa bo vložena v razlago, kako se je nekaj zgodilo. To lahko vključuje tudi pritoževanje (SkillsYouNeed, 2020). Različna okolja imajo za posameznike različen pomen in pomembnost. $\mathrm{Na}$ tej ravni se lahko prepozna določene elemente, ki so specifični za določeno skupnost. Ko se odločimo za izboljšanje, razvoj ali spremembe, bodo rezultati na tej ravni največkrat prepoznavni skozi posameznikovo vedenje (Turner, 2017). 
Vera, religija.

Vloge, ki jih igramo, kaj mislimo, da smo.

Presoja in ocena sebe in drugih.

Sposobnosti, ki jih imamo.

Kako se obnašamo.

Lokacija in kontekst.

\section{Poslanstvo.}

Duhovnost.

\section{Identiteta.}

$\mathrm{Kdo}$ ?

Vrednote in prepričanja. Zakaj?

\section{Spretnosti in sposobnosti.}

Kako?

\section{Vedenje.}

Kaj?
Moj prostor $\mathrm{V}$ večjem sistemu.

Sem ...

Motivacija, namen.

Kompetence.

Miselni procesi, fizične akcije in reakcije.

Rezultati in izidi.

\section{Slika 3: Nevrologične stopnje sprememb po Diltsu}

(Turner, 2017)

Vedenje se nanaša na dejanja in reakcije posameznika v danem okolju. Oseba, ki deluje na tej ravni, bo opisala, kaj si je mislila (duševno vedenje) in kaj je storila (fizično vedenje), pa tudi, kakšen učinek so ta vedenja imela. V terapevtskem smislu ali pri »coachingu« pa bi se nanašalo lahko tudi na to, kaj bi lahko storili in kakšen vpliv bi lahko to imelo na izid (Turner, 2017). Obnašanje je lahko dobro ali škodljivo za človeka in okolje. Boonman (2018) navaja, da v organizaciji lahko pride do škodljivega vedenja na kateri koli ravni in $\mathrm{v}$ vsakem trenutku, bodisi s strani sodelavcev, vodij, delodajalcev ali strank. Zaradi hierarhične neenakosti med zaposlenimi in delodajalcem ter zaradi delodajalčeve moči vplivanja na delovne pogoje so na primer na Nizozemskem sprejeli zakon, ki nalaga delodajalcu pravno dolžnost skrbnosti. Ta dolžnost skrbnosti zahteva, da je delodajalec odgovoren za ustvarjanje zdravega delovnega okolja, in preprečuje ponižujoče vedenje na delovnem mestu, na vseh ravneh in ves čas, in sicer: 
- Zahteva, da sta tako delodajalec kot zaposleni razumna in poštena $\mathrm{v}$ svojem poklicnem odnosu.

- Določa odgovornost delodajalca za dajanje jasnih navodil in pri tem poskrbi za vse potrebne ukrepe za preprečevanje trpljenja ali poškodb zaposlenega.

- Določa delodajalčevo odgovornost za morebitno škodo, ki jo je utrpel zaposleni med opravljanjem dejavnosti, povezanih z delom.

- Določa odgovornost delodajalca za izvajanje preventivne politike. V primerih, ko takšna politika ne uspe, je delodajalec dolžan omejiti posledice previsoke delovne obremenitve in psihosocialnega stresa.

Spretnosti in sposobnosti. To je $\mathrm{v}$ bistvu raven zmožnosti ali kompetenc, $\mathrm{z}$ drugimi besedami: kaj je posameznik sposoben narediti. Zato lahko tej ravni rečemo tudi stopnja »kako« (Turner, 2017). Kombinacija znanj, veščin, sposobnosti in osebnih lastnosti posameznika pripomore $\mathrm{k}$ njegovi uspešnosti in na koncu tudi uspeha organizacije kot celote (Univerza v Nebraski - Lincoln, 2020). Sposobnost usmerja vedenje preko osebnih strategij, ki vključujejo določene veščine in njihov razvoj. Oseba, ki deluje na tej ravni, se pogovarja in razmišlja o tem, kako nekaj doseči, vključno s spretnostmi, ki bi jih morala razviti, da bi želeno lahko dosegla (Turner, 2017).

Vrednote in prepričanja se nanašajo na temeljne presoje in ocene sebe, drugih in sveta okoli nas. Določajo to, kako dogodki dobijo pomen in so središče motivacije in kulture. Naša prepričanja in vrednote nam dajejo moč (motivacija in dovoljenje), ki podpira ali zavira določene sposobnosti in vedenja. Prepričanja in vrednote se nanašajo na vprašanje »zakaj« (Dilts, 2014).

Prepričanja so odlična podlaga za vse, kar posameznik dela z namenom, da bi se spremenil. Če ljudje res verjamejo, da nečesa ne morejo storiti, bodo nezavedno našli način, kako preprečiti spremembo. Našli bodo način, kako interpretirati stvari in rezultate, da bodo le-ti ustrezali njihovim obstoječim prepričanjem. Vsi smo sprejeli neka prepričanja, stališča, pričakovanja iz določene kulture in družbe, ki izhajajo iz osebnih izkušenj, ki so jih sprejeli drugi in so ustvarjeni iz morebitnih preteklih travm ter so posplošeni zaradi ponavljanja. Vsaka oseba ima svoj sistem prepričanj, ki so tesno povezana $z$ njegovimi osebnimi vrednotami in merili in lahko pomembno vplivajo na motivacijo, odločanje in uspešnost. Oblikujejo tako voljo do življenja, 
zmožnost soočanja s stresom kot tudi razvoj in oblikovanje pozitivnih življenjskih načrtov, ciljev in potreb (Landsiedel, 2020).

Identiteto predstavlja nekaj, za kar se človek ali skupina ima. Ta raven se nanaša na edinstvene, razločevalne značilnosti, ki opredeljujejo posameznika, skupino ali organizacijo (Logical Level Inventory, 2020). Naše dojemanje identitete oblikuje naša prepričanja, zmožnosti in vedenja v enoten sistem. Občutek identitete se nanaša tudi na naše dojemanje sebe $v$ zvezi z večjimi sistemi, katerih del smo, in določa našo vlogo, namen in poslanstvo (Dilts, 2014). Identiteta je v tem, kdo si, in percepcija samega sebe. Pogovori na tej ravni so pogosto o tem, kdo posameznik misli, da je, in kako se vidi. $\mathrm{Na}$ primer: »Verjamem, da sem $\mathrm{dobra} / \mathrm{slaba} /$ srečna/nesrečna/inteligentna/neumna oseba« itd. Vsak posameznik ima nenehno notranje pripovedovanje o tem, kdo in zakaj je, ter o svojem mestu na svetu (Turner, 2017).

Poslanstvo ni vedno vključeno v logične ravni in bi ga lahko obravnavali kot korak višje od drugih. Gre za nekaj večjega, kar presega posameznika, in je povezano s tem, da je posameznik del večjega sistema, naj si bo to družina, skupnost ali kaj drugega. Za nekatere ljudi to raven predstavlja njihova vera ali religija. Nekateri temu pravijo raven »modrosti«, medtem ko jo drugi v celoti izključujejo ali povezujejo z ravnjo identitete, torej kot del tega, kako posameznik vidi sebe (Turner, 2017). Nekateri pravijo tej stopnji pripadnost. To je najgloblja raven, na kateri postavljamo največja metafizična vprašanja. Zakaj smo tukaj? Kaj je smisel življenja? Ta duhovna raven vodi in oblikuje naše življenje in daje temelje našemu obstoju. Vsaka sprememba na tej ravni močno vpliva na vse ravni. V nekem smislu vsebuje vse, kar počnemo, vendar je veliko več kot samo seštevek posameznih delov (Landsiedel, 2020).

$\mathrm{V}$ kateri koli organizaciji lahko model logičnih ravni uporabimo pri odkrivanju usklajenosti na različnih ravneh oziroma za diagnosticiranje neskladij. Vsako nalogo, spremembo, projekt ali cilj je treba uskladiti, da bi lahko služili organizaciji, enako velja tudi za učenje in razvoj. Neskladje lahko povzroči neprijetnosti, konflikt in paradoks v organizaciji (Cheal, 2008). 


\section{$5 \quad$ Vodenje v času kriz in sprememb}

Živimo v časih, ko se vsak dan pojavljajo različne vrste kriz. Naravne katastrofe, okoljske grožnje, finančni zlomi, gospodarske krize, teroristični napadi, epidemije, propadi podjetij itd. Vse to pomembno vpliva na varnost poslovanja, na povečanje negotovosti in nestanovitnosti na trgih ter povzroča strah in stres. Kot odziv na pomanjkanje odgovorov, ki jih zagotavljajo tradicionalni pristopi kriznega upravljanja, se je pojavil nov koncept kriznega vodenja (Thach, 2012). V kriznih časih je dobro vodenje tisto, kar je najpomembnejše. V teh časih se rojevajo voditelji brez naslovov. V času krize se tisti, ki jih prizadenejo kaos, zmeda in obup, obrnejo k drugim, da bi jim povedali, kaj naj naredijo (Olafsson, 2013). Nedavne raziskave kažejo, da so vodstvene lastnosti in vedenja tistih, od katerih so posamezniki oziroma zaposleni odvisni v kriznih časih, drugačne od tistih, ki jih le-ti potrebujejo v času stabilnosti (Knights \& McCabe, 2015). Poleg tega so se običajno uporabljeni tradicionalni načini vodenja izkazali za neustrezne za obvladovanje in vodenje $\mathrm{v}$ kriznih razmerah (Haddon, Loughlin, \& McNally, 2015).

Vsaka kriza pomeni spremembe in spodbuja tranzicije. Pri obvladovanju sprememb v organizaciji, pa četudi še tako majhnih, lahko od zaposlenih pričakujemo najrazličnejše reakcije. Nekateri bodo šokirani, zaskrbljeni ali jezni, drugi bodo lahko navdušeni ali nestrpni, tretji ambivalentni. Da bo delovanje zaposlenih zavzeto, uspešno in produktivno, jim moramo pomagati, da čim bolje sprejmejo spremembe in se pri tem dobro počutijo (Tasmanian Vlada, 2020). Eden najbolj mučnih in zahtevnih problemov, s katerimi se srečujejo managerji, je ravno odpor zaposlenih do sprememb. Takšen odpor se lahko kaže v različnih oblikah: kot vztrajno zmanjševanje produktivnosti, povečanje absentizma, povečanje števila prošenj za premestitev, neprestani prepiri, sovraštvo, sabotaže ali upočasnjevanje dela in iskanje številnih razlogov, zakaj sprememba ne bo delovala. Še tako nepomembne oblike takšnega ali drugačnega upiranja pa so za organizacijo lahko zelo moteče (Lawrence, 1969). Odpor upočasni proces sprememb in ustvarja negativen občutek ter zmedo. Če je sprememba težavna in smo pod stresom, se zna zgoditi, da bomo skušali prezreti tiste, ki se upirajo, ali pa bomo z njimi zašli v konflikt. Čeprav se na prvi pogled zdi, da bi bilo najlaže, če upornike izločimo iz procesa sprememb, je morda smiselno poskusiti prepričati vsaj nekatere izmed njih, da bo želeno spremembo možno realizirati. Le-ti imajo namreč lahko zelo močan vpliv na to, kako dobro se bo implementirala sprememba in kakšen bo napredek (Tasmanova vlada, 2020). Čeprav se izkušeni vodje tega precej dobro zavedajo, pred organizacijsko 
spremembo posvetijo presenetljivo malo časa temu, da bi sistematično preučili, kdo se lahko upira pobudi za spremembo in zakaj. Namesto tega se na osnovi preteklih izkušenj oklepajo določenih prepričanj, kot na primer: »Inženirji se bodo verjetno uprli spremembam, ker želijo biti neodvisni in dvomijo v ukrepe vodstva.« Tak pristop pa lahko povzroči resne težave. Zaradi številnih različnih načinov, kako se lahko posamezniki in skupine odzovejo na spremembe, težko pravilno ocenimo situacijo in rešitve niso kar očitne, ampak zahtevajo temeljit premislek (Kotter in Schlesinger, 2008).

Kotter in Schlesinger (2008) navajata, da je pri obvladovanju sprememb najpogostejša napaka managerjev to, da uporabljajo samo en pristop ali omejen sklop pristopov, ne glede na situacijo. S tem se srečuje presenetljivo veliko število vodij. Bodisi da gre za trdoglavega vodjo, ki pogosto priganja zaposlene; v ljudi usmerjenega vodjo, ki nenehno poskuša vključevati in podpirati svoje ljudi; ciničnega vodjo, ki vedno manipulira $z$ drugimi; intelektualnega vodjo, ki se močno zanaša na izobraževanje in komunikacijo; ali odvetniškega vodjo, ki se običajno skuša pogajati. Druga pogosta napaka, ki jo storijo vodje, pa je, da k spremembam pristopijo nepovezano, necelovito in postopno, brez jasne strategije.

V nadaljevanju navajamo določene elemente, ki lahko managerjem oziroma vodjam pomagajo pri vodenju zaposlenih $\mathrm{v}$ času krize, sprememb in tranzicije.

Izobraževanje in komunikacija. Eden najpogostejših načinov za premagovanje sprememb je predhodno izobraževanje ljudi o tem. Razlaga idej in ustrezna komunikacija pomagata ljudem videti potrebo po spremembi in logičnost njene vpeljave. Izobraževalni program in ustrezno komuniciranje sta idealna, kadar odpor temelji na neustreznih ali netočnih informacijah in analizah, zlasti če pri izvedbi spremembe potrebujemo pomoč tistih, ki se spremembi upirajo. Toda nekateri managerji spregledajo dejstvo, da takšen program zahteva dobre odnose med pobudniki sprememb in tistimi, ki se spremembi upirajo ali ne verjamejo, kar slišijo. Izvedba tega zahteva čas in trud, zlasti če sodeluje veliko ljudi (Kotter in Schlesinger, 2008).

Po mnenju Haggertyja (2017) je komunikacija v času krize in sprememb eden najpomembnejših elementov obvladovanja krize. Slaba komunikacija o spremembi (namen, obseg, časovni razpored, osebje) lahko privede do dvoumnosti in zmede in lahko sproži negativne reakcije med zaposlenimi. Zaposleni morajo vedeti, kaj se 
dogaja, še zlasti, če bo to vplivalo na njihova delovna mesta. Zaposleni, ki so obveščeni o situaciji in dogajanjih, občutijo običajno višjo stopnjo zadovoljstva z delom kot zaposleni, ki niso obveščeni. Zato največji odpor do sprememb predstavlja ravno slaba obveščenost. Komunikacija pa mora biti dvosmerna, prav tako poslušanje (Tasmanian Vlada, 2020).

$\mathrm{V}$ času vpeljave sprememb je pomembno, kaj in kako se sporoča zaposlenim ter da se jih pri tem podpira. Pomembno je, da se zaposleni zavedajo, zakaj se spremembe uvajajo, in da znamo sprejete odločitve glede sprememb tudi utemeljiti. Biti moramo iskreni o tem, kaj to pomeni za zaposlene in kakšna bo njihova prihodnost $\mathrm{v}$ podjetju, jasno jim moramo predstaviti postopke, povezane s spremembami, vključno z možnostjo prerazporeditve, ter biti konsistentni v sporočanju (Tasmanian Government, 2020).

Sodelovanje in vključenost. Nikoli ne moremo pričakovati stoodstotne podpore s strani posameznika, ki ni bil osebno vpleten v oblikovanje sprememb, ki bodo vplivale na njegovo delo. Pri veliko spremembah, zlasti tistih, ki vplivajo na celotno organizacijo, je nemogoče vključiti vse zaposlene, sploh ne v vsako odločitev. Kadar pa spremembe delujejo, je to velikokrat ravno zato, ker je organizacija vključila sodelovanje zaposlenih (Heathfield, 2019). Vključenost zaposlenih se opazi v angažiranosti in navdušenosti posameznikov, ki jim je bilo zaupano, da prispevajo $\mathrm{k}$ spremembi. To pa je nekaj, česar si še posebej želimo v kriznih situacijah.

Podpora. Pomemben način, kako si lahko upravljavci pomagajo v času sprememb, je nudenje podpore zaposlenim. To lahko vključuje usposabljanje za pridobitev novih veščin, zagotavljanje prostega časa po napornem obdobju ali preprosto samo poslušanje in zagotavljanje čustvene podpore. Podpora je izrednega pomena sploh takrat, kadar se v središču zaposlenih pojavita strah in tesnoba (Kotter \& Schlesinger, 2008).

Pogajanja. Pri komunikaciji zaposlenih znotraj organizacije se pojavljajo razlike. Vodstvo se mora naučiti odpraviti te razlike, da se izogne izpadu obstoječih sistemov. Do konfliktov pride, kadar imajo posamezniki v organizaciji različne interese. Obvladovanje konfliktov pa zahteva ustrezne strategije za ustvarjanje harmonije med konfliktnimi stranmi. Vzpostaviti je treba strategije za hitro odzivanje na vprašanja, ki se nanašajo in vplivajo na organizacijo. Postopek pogajanj omogoča, da vpleteni strani oblikujeta zavezujoči dogovor ali sporazum, tako da 
neizpolnjevanje le-tega povzroči določene posledice, ki jih mora tisti, ki dogovora ne izpolnjuje, tudi nositi (Business Essays, 2020).

Vplivanje. Pogosto slišimo, da je pri pravem vodenju pomembna sposobnost vplivanja in ne avtoriteta. Večina organizacij v času industrijske dobe je bila zgrajena na konceptu centralizirane oblasti in hierarhičnih organizacijskih lestvic. Temeljile so na predpostavki, da posamezniki, ki se nahajajo niže na hierarhični lestvici in opravljajo rutinske, natančno določene naloge, nimajo potrebe, da bi videli celotno sliko. Kot rezultat tega so bili uvedeni managerski nivoji in vsak manager je bil odgovoren za nadzor nad podrejeno skupino zaposlenih, ki mu je poročala. Ko pa nastopi kriza, je velikega pomena ohranjanje celotne slike in velikokrat je edini izhod inovativno razmišljanje in tesno sodelovanje s tistimi, ki so problemu najbliže. $\mathrm{V}$ takem primeru pa hierarhija organizacijskega upravljanja oziroma avtoriteta ne deluje. V zadnjih dveh desetletjih so vodje prepoznali, da je sposobnost vplivanja pravzaprav veliko pomembnejši dejavnik kot avtoriteta. Sposobnost vplivanja na ljudi nas pripelje veliko dlje kot oblast nad njimi. Vplivanje pomeni, da drugi delijo našo vizijo prihodnosti in nam sledijo sami, ne pa da jih $\mathrm{k}$ temu porivamo. Tisti, na katere uspemo vplivati, da delijo našo vizijo, ne bodo šli samo v koraku z nami, ampak nam bodo $\mathrm{v}$ mnogih primerih pomagali to vizijo prenesti tudi na druge (Olafsson, 2013).

Uspešnost prizadevanja za uvedbo organizacijskih sprememb je odvisna od spretne uporabe številnih pristopov, pogosto v zelo različnih kombinacijah. Pri tem pa je pomembno, da managerji uporabljajo te pristope $z$ veliko mero rahločutnosti in da so sposobni realno oceniti situacijo (Kotter in Schlesinger, 2008).

\section{$6 \quad$ Zaključek}

Večina organizacij, ki se sooči s krizo, se zanaša na trenutno vodstvo, da jih bo popeljalo iz krize. $V$ tem času se vrstijo številni pritiski na vodstvo, da se le-to proaktivno odzove na krizo. Zato je izrednega pomena, da managerji in vodje $\mathrm{v}$ času krize popolnoma razumejo procese, ki se dogajajo v času sprememb. Šele tako bodo lahko uspešno popeljali svoje organizacije skozi nemirno obdobje. Veliko vodij pa se pri tem bolj kot na razumevanje procesa sprememb zanaša na instinkt in izkušnje. Nekateri se zaradi strahu pred spremembami celo upirajo neizogibni preobrazbi organizacije in zaposlenih. Bruckman (2008) trdi, da je tako ravnanje za organizacijo 
tvegano, ne glede na to, ali se sooča z nepričakovanimi ali pa načrtovanimi spremembami.

Managerji so odgovorni tako za izvajanje prednostnih nalog podjetja in upravljanje v okviru finančnih zmožnosti kot tudi za posvetovanje z zaposlenimi ter nudenje podpore zaposlenim. Na pomembne spremembe in tudi na bližajoče se spremembe na delovnem mestu zaposleni reagirajo na različne načine, ki s časom spreminjajo svojo intenziteto. Za najboljše obvladovanje sprememb je pomembno, da vodstvo prepozna, da bo prišlo do vpliva, in da je obveščeno o dogajanju. Prav tako je pomembno, da o tem obveščajo tudi zaposlene, da jim dajejo smernice in povratne informacije, da so na voljo za vprašanja, poslušajo, opazujejo in sočustvujejo. Zaposleni se bodo znašli v različnih fazah tranzicije oziroma prehoda na krivulji sprememb. Zavedati se moramo, da so prehodi lahko pričakovani ali nepričakovani, dobrodošli ali nezaželeni, izbrani ali vsiljeni, nenadni ali postopni in da je naravna težnja zaposlenih, da se pri svoji rutini upirajo spremembam. Nekateri se lahko počutijo ogrožene, da se jim bo odvzelo tisto, kar jim je znano. Lahko se počutijo preobremenjene, razočarane ali jezne. Zato je pomembno spremljati reakcijo zaposlenih na spremembe in poskušati razumeti njihove reakcije in težave. Poznavanje in uporaba različnih tranzicijskih modelov pa lahko v takih primerih pripomoreta k učinkovitemu izvajanju sprememb. Managerji morajo obvladovati zaposlene glede na njihov položaj na krivulji sprememb, biti morajo potrpežljivi, kajti spremembe potrebujejo čas, poiskati morajo razloge za odpor, poslušati, razmišljati, pogledati okoli sebe in razviti strategije za reševanje konkretnih situacij. Odpor pogosto izvira iz občutka, da posameznik ni slišan, da nima kontrole, nobene besede pri stvari, da se ga ne spoštuje, se mu ne zaupa, ne verjame in se ga ne vpleta v samo dogajanje.

Za zaključek lahko rečemo, da sta dva najbolj kritična elementa vodenja prav uvajanje in obvladovanje sprememb. Večina organizacij se dvigne ali pade glede na to, kako dobro obvladuje uvedbo sprememb in kako dober je njihov nadzor nad nepričakovanimi spremembami v njihovem okolju.

\section{Literatura}

Adelman, D. (2020). Life transitions: The only thing constant is change. Pridobljeno 14. 1. 2020, http://drewadelman.com/life-transitions 
Anastasia (2015). Understanding the Kubler-Ross Change Curve. Pridobljeno 15. 1. 2020, https://www.cleverism.com/understanding-kubler-ross-change-curve/

Bernstein, J. (2011). Manager's Guide to Crisis Management. New York: McGraw-Hill.

Boin, A., 't Hart, P., \& Kuipers,S. (2018). The Crisis Approach. V H. Rodriguez, W. Donner, \& J. E. Trainor (ur.), Handbook of Disaster Research (pp. 23-38). Switzerland: Springer International Publishing.

Boonman, G. (2018). Reventing harmful behaviour in the workplace. Pridobljeno 17. 1. 2020, https://www.legalexpatdesk.nl/preventing-unhealthy-work-environment/

Bruckman, J. C. (2008) Overcoming Resistance to Change: Causal Factors, Interventions, and Critical Values. The Psychologist-Manager Journal, 11(2), 211-219, DOI: 10.1080/10887150802371708.

Business Essays (2020). Crisis Management, Conflict Management and Negotiation. Pridobljeno 22. 1. 2020, https://businessays.net/crisis-management-conflict-management-and-negotiation/

Connelly, M. (2018). Kubler-Ross Five Stage Model. Pridobljeno 15. 1. 2020, https://www.changemanagement-coach.com/kubler-ross.html

Crowe Associates Ltd. (2020). Managing Change. Pridobljeno 26. 1. 2020, https://www.croweassociates.co.uk/managing-change/bridges-transition-model/

Dilts, R. (2014). A Brief History of Logical Levels. Pridobljeno 21. 1. 2020, http://www.nlpu.com/Articles/LevelsSummary.htm

Discovery in Action (2015). Logical Levels of Change - Robert Dilts. Pridobljeno 17. 1. 2020, https://discoveryinaction.com.au/logical-levels-of-change-robert-dilts/

Haddon, A., Loughlin, C., \& McNally, C. (2015). Leadership in a time of financial crisis: What do we want from our leaders? Leadership and Organization Development Journal, 36(5), 612-627.

Haggerty, J. F. (2017). Chief Crisis Officer: Structure and Leadership for Effective Communications Response. California: American Bar Association.

Hall, L. (2015). Models and frameworks for exploring change and transition. V L. Hall (ur.), Coaching in times of crisis \& transformation: How to help individuals and organizations flourish (pp. 29-49). Philadelphia, USA: Kogan Page Limited.

Heathfield, S. M. (2019). Change Management Lessons about Employee Involvement. Pridobljeno 22. 1. 2020, https://www.thebalancecareers.com/change-management-lessons-about-employeeinvolvement-1917806

Hermann, C. F. (1972). Some issues in the study of the international crisis. V C. F. Hermann (ur.), International Crises: Insights from behavioural research (pp. 3-17). New York: Free Press.

James, K. J. \& Gilliland, B. E. (2013). Crisis Intervention Strategies. Belmont, CA: Brook/Cole.

James, E. H., Wooten, L.P., \& Dushek, K. (2011). Crisis management: Informing a new leadership research agenda. The Academy of Management Annals, 5(1) (2011) 455-493.

Janse, B. (2019). Bridges Transition Model. Pridobljeno 16. 1. 2020, https://www.toolshero.com/change-management/bridges-transition-model/

Joelson, R. B. (2020). Managing Difficult Life Transitions. Pridobljeno 15. 1. 2020, https://richardbjoelsondsw.com/articles/managing-difficult-life-transitions/

Knights, D. \& McCabe, D. (2015). Masters of the Universe: Demystifying leadership in the context of the 2008 global financial crisis. British Journal of Management, 26(2), 197-210

Kotter, J. P. \& Schlesinger, L. A. (2008). Choosing Strategies for Change. Harvard Business Review, 86, 78.

Kramer, R.M. \& Tyler, T.R. (1995). Trust in organizations: Frontiers of theory and research. Thousand Oaks, CA: Sage Publications.

Landsiedel (2020). The Neurological Levels - The Dilts Pyramid. Pridobljeno 21. 1. 2020, https://www.landsiedel.com/en/nlp-library/neurological-levels.html

Lawrence, P. R. (1969). How to Deal With Resistance to Change. Harward Business Review, 47(1), 4-6.

Lebringer, O. (2012). The Crisis Manager: Facing disasters, conflicts, and failures. Oxon: Routledge.

$\begin{array}{llllll}\text { Logical levels Inventory. (2020). Pridobljeno } & \text { 21. } & 1 . & \text { 2020, }\end{array}$ https://www.logicallevels.co.uk/pages/logical-levels-model

Mileti, D. S. (1999). Disasters by Design A Reassessment of Natural Hazards in the United States. Washington, DC: Joseph Henry Press. https://doi.org/10.17226/5782. 
Mind Tools (2018a). The Change Curve: Accelerating Change, and Increasing Its Likelihood of Success. Pridobljeno 3. 2. 2020, https://www.mindtools.com/pages/article/newPPM_96.htm

Mind Tools (2018b). Bridges' Transition Model Guiding People through Change. Pridobljeno 28. 1. 2020, https://www.mindtools.com/pages/article/bridges-transition-model.htm

Olafsson, G. (2013). The Crisis Leader: The Art of Leadership in Times of Crisis. United States: Lorien Consulting.

Pearson, S. (2020). How to Use Bridges' Transition Model to Facilitate Change. Pridobljeno 26. 1. 2020, https://tallyfy.com/bridges-transition-model/

Roberts, A.R. (2002). Myths, facts and realities regarding battered women and their children: An overview. V A.R. Roberts (ur.), Handbook of domestic violence: Intervention strategies (pp. 3-22). New York: Oxford University Press.

Rosenthal, U., Cherles, M. T., \& 't Hart, P. (EDS.) (1989). Coping with Crisis: The management of disasters, riots and terrorism. Springfield: Charles. T. Thompson.

SkillsYouNeed (2020). Dilts' Logical Levels. Pridobljeno 3. 2. 2020, https://www.skillsyouneed.com/lead/logical-levels.html

Thach, L. (2012). Managerial perceptions of crisis leadership in public and private organizations: An interview study in the United States. International Journal of Management, 29(2), 712-725.

Talbott, C. (2013). Essential Career Transition Coacbing Skills. Hove: Routledge.

Tasmanian Government (2020). Transition and Change. Pridobljeno 3. 2. 2020, http://www.dpac.tas.gov.au/divisions/ssmo/change_management/transition_and_change

Turner, J. (2017). Robert Dilts' Neurological Levels. Pridobljeno 26. 1. 2020, https://lifemanagement.co.uk/index.php/2018/12/20/neurological-levels/

University of Nebraska - Lincoln (2020). Core Competencies. Pridobljeno 3. 2. 2020, https://hr.unl.edu/compensation/nuvalues/corecompetencies.shtml/

Wlliam Bridges Associates. (2020). What is William Bridges' Transition Model? Pridobljeno 16. 1. 2020, https://wmbridges.com/what-is-transition/

Zupančič, N. (2018). Poslovno svetovanje: Ali lahko rešimo organizacije, ki gredo skozi spremembe? Pridobljeno 28. 1. 2020, https://psihologijadela.com/2018/08/29/poslovno-svetovanje-alilahko-resimo-organizacije-ki-gredo-skozi-spremembe/ 
IZZIVI KADROVSKEGA MANAGEMENTA V XXI. STOLETJU

M. Ferjan (ur.)

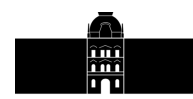

\section{Recenzije}

MITJA GORENAK

BRANKO LOBNIKAR

BRIGITA SKELA SAVIČ 



\section{IZZIVI KADROVSKEGA}

MANAGEMENTA

\section{XXI. STOLETJU}

\author{
MARKO FERJAN \\ Univerza v Mariboru, Fakulteta za organizacijske vede, Kranj, Slovenija. \\ E-pošta: marko.ferjan@um.si
}

Povzetek Marko Ferjan obravnava fenomene: zadovoljstva pri delu, organizacijske klima in zavzetosti. Koncept zadovoljstva pri delu izhaja iz paradigme organizacijskega vedenja. Konec 20. stoletja se je že zdelo, da $\mathrm{v}$ teoriji in praksi kadrovskega managementa koncept zadovoljstva ni več aktualen. Vendar v zadnjem obdobju merjenje zadovoljstva $\mathrm{v}$ povezavi z merjenjem zavzetosti spet postaja aktualno. Marsikatera današnja anketa zadovoljstva pa ne upošteva spoznanj znanosti, ni pa zanemarljivo, da je pri uporabi anket o zadovoljstvu včasih prihajalo tudi do zlorab. Zato se je avtor odločil za ponovno obravnavo te teme. Iztok Podbregar, Antonia Novak in Polona Šprajc obravnavajo prepoznavanje, spodbujanje in vključevanje raznolikosti talentov. Eva Jereb v prispevku poda značilnosti trenutno najbolj zastopanih generacij na delovnih mestih $\mathrm{v}$ organizacijah. Vesna Novak obravnava razširjenost prekarnega dela. nameni posledicam prekarnosti. Eva Jereb in Marko Urh se ukvarjata $\mathrm{s}$ spremembami in tranzicijo $\mathrm{v}$ času krize ter vloga vodstva organizacij pri tem.
Ključne besede:

kadrovski

management, zavzetost, delo s

talenti, prekarno delo, krizni management, medgeneracijsko sodelovanje pri delu. 


\title{
Challenges of Human RESOURCES MANAGEMENT IN XXI. CENTURY
}

\author{
MARKO FERJAN \\ University of Maribor, Faculty of Organizational Sciences, Kranj, Slovenia. \\ E-mail: marko.ferjan@um.si
}

Keywords:

human

resources

management,

work

engagement,

talent

management,

precarious

work, crisis

management,

intergenerational

cooperation at the

workplace.

Abstract Marko Ferjan deals with phenomena: job satisfaction, organizational climate and work engagement. The concept of job satisfaction stems from the paradigm of organizational behavior. At the end of the 20th century, it already seemed, that the concept of job satisfaction was no longer relevant. Recently, however, measuring job satisfaction in conjunction with work engagement has become relevant again. Iztok Podbregar, Antonia Novak and Polona Šprajc discuss the recognition, promotion and inclusion of diversity of talents. In her article, Eva Jereb gives the characteristics of the currently most represented generations in jobs in organizations. Vesna Novak discusses the prevalence of precarious work. intended for the consequences of precariousness. Eva Jereb and Marko Urh deal with change and transition in times of crisis and the role of organizational leadership at this. 



$$
\text { imi }
$$

Univerza v Mariboru

Fakulteta za organizacijske vede 